UNIVERSIDADE DE SÃO PAULO

MUSEU DE ARQUEOLOGIA E ETNOLOGIA

PROGRAMA DE PÓS-GRADUAÇÃO EM ARQUEOLOGIA

\title{
SÍTIOS LITIICOS NO INTERIOR PAULISTA: UM ENFOQUE REGIONAL
}

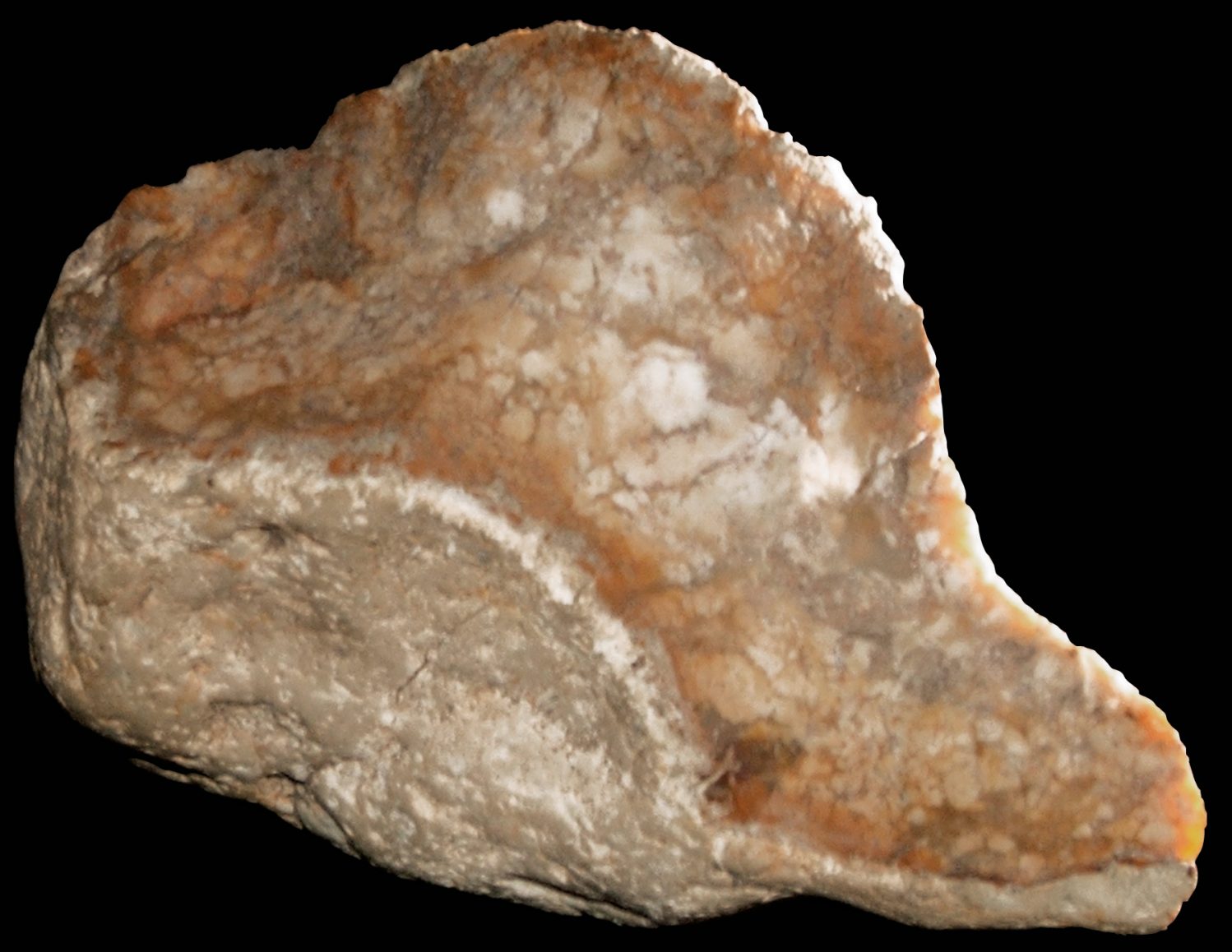

Fábio Grossi dos Santos
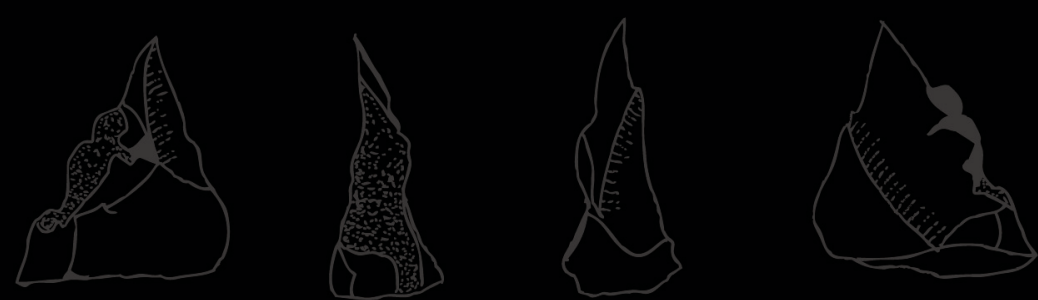


\section{UNIVERSIDADE DE SÃO PAULO MUSEU DE ARQUEOLOGIA E ETNOLOGIA PROGRAMA DE PÓS-GRADUAÇÃO EM ARQUEGOLOGIA}

\section{SÍTIOS LÍTICOS NO INTERIOR PAULISTA: UM ENFOQUE REGIONAL}

Fabio Grossi dos Santos

Dissertação apresentada ao Programa de Pós-Graduação em Arqueologia ao Museu de Arqueologia e Etnologia da Universidade de São Paulo, para obtenção do título de Mestre em Arqueologia.

Orientadora: Prof ${ }^{a}$. Dra. Silvia Maranca

Linha de Pesquisa: Artefatos e Cultura Material: Significados e Potencialidades

SÃO PAULO

2011 


\section{AGRADECI MENTOS}

É preciso mencionar, antes de tudo, que a realização deste trabalho só foi possível porque mesmo antes de seu início, sempre contei com pessoas dispostas a ajudar. Quer no plano das idéias: discutindo, sugerindo, instruindo, criticando, debatendo; ou mesmo na prática, com ajuda de campo e em laboratório. Ou mesmo aqueles que cederam seu tempo para contribuir de alguma forma. Dessa maneira, esse trabalho não é fruto de um único autor, e sim de um grupo de pessoas afins. Claro que a redação do texto é de minha autoria, e, por isso mesmo, as idéias aqui expostas são de minha responsabilidade, sejam elas felizes ou não. Mas vejo, sobretudo, essa obra como fruto da Amizade. Por isso mesmo é imprescindível que deixe aqui meus agradecimentos.

Agradeço primeiramente a duas pessoas que fizeram parte de minha formação na Arqueologia. Pessoas com as quais comecei na carreira e que me instruíram, e continuam instruindo. Mas não são somente professores, são acima de tudo grandes amigos, que me ensinaram não só o ofício de Arqueólogo, mas também me passaram o exemplo de seres humanos íntegros e de respeito. Movidos pelo ideal e que empregam amor no que fazem, contagiando assim, a todos que deles se aproximam. Obrigado Robson Antonio Rodrigues e Solange Nunes de Oliveira Schiavetto pelo exemplo que são para mim e muitos outros. Agradeço também por todas as vezes que se dispuseram a ler e corrigir com atenção os textos que lhes enviei, por todas as vezes que pedi socorro e da grande paciência com esse aprendiz - especialmente pelas peripécias em campo.

Meus agradecimentos também para:

- minha grande amiga Dulcelaine Lopes Nishikawa, minha co-piloto de desvios nas estradas da vida - mas sempre chegamos lá, e com bom humor; mesmo com os contratempos. Agradeço também ao Mário e a Sofia Nishikawa;

- Henry Luydy Abraham Fernandes por ter me ensinado tanto em tão pouco tempo, de forma tão didática e paciente.

- os professores Águeda Vilhena Vialou e Denis J. P. Vialou, por representarem exemplos dos Arqueólogos ideais, sua influência para mim é grande. São pessoas de grande sabedoria e humildade, tratando a todos que se aproximam com grande carinho. 
- a professora Marisa Coutinho Afonso, por sempre me tratar com extrema atenção, tirando todas as minhas dúvidas desde que comecei a freqüentar o MAE como aluno especial em 2005;

- a Professora Niède Guidon, pelo exemplo de uma conterrânea;

- Virgínia de Gobbi, diretora do Museu Voluntários da Pátria e MAPA - Museu de Arqueologia e Paleontologia de Araraquara, pela atenção que me deu, atendendo de pronto meus pedidos, dando-me permissão para trabalhar com o acervo dos sítios BES II e II e cedendo o espaço do laboratório para analisá-lo;

- os ex-diretores do Museu Municipal de Jaú, Teresinha e Guilherme Valente, por sempre me apoiarem, incentivarem e cederem o espaço do museu para desenvolver minhas atividades;

- os amigos do Grupo de Estudos Arqueológicos de Araraquara: Renan Pezzi, Sara Herter, Roberto Ávila e Diego Fleming pela ajuda valiosa na análise dos sítios BES II e III. Especialmente a Diego Fleming que me acompanhou até o fim, algumas vezes deixando suas atividades pessoais de lado para me auxiliar. Esses contribuíram muito, não só na ajuda técnica, mas também com idéias que surgiam durante o trabalho e muitas risadas;

- os que me ajudaram na etapa de campo, deixando suas atividades pessoais simplesmente pela amizade. Isso nunca será esquecido. Obrigado novamente ao Robson, a Dulce e ao Diego. Agradeço ainda a Adriana Saraiva (lela), ao Pedro Michelluti. A este também agradeço pelas contribuições nas análises geológicas e descrições dos solos. Agradeço também a Louise Prado Alfonso por sua ajuda em campo e pela amizade. Grande amiga, companheira de aventuras, congressos, risadas, chocolates e pratos vegetarianos;

- Carolina Guedes e Flávia Cerqueira, também grandes amigas e companheiras de aventuras e congressos;

- Juliana Luz, pela amizade e companheira de mestrado;

- Gilberto da Silva Franciso, pela amizade e exemplo de verdadeiro intelectual que representa para mim;

- os amigos Ricardo e Humberto Guerra pelo desenvolvimento da parte gráfica deste trabalho;

- Ítalo Tsuchiya pela elaboração dos mapas; 
- Claide de Paula Moraes pela permissão de usar seus fantásticos desenhos dos instrumentos do Sítio Dois Córregos;

- Paulo E. Zanettini por sempre ser tão solícito, dando permissão para usar o material dos sítios BES e me disponibilizar todas as informações que pedi. Agradeço também a toda a equipe de sua empresa;

- Maria do Carmo Mattos Monteiro dos Santos e à Scientia Consultoria Científica por me atender em todos os momentos com extrema educação e disponibilizar o material do Sítio Dois Córregos e outras informações que precisei;

- Wesley Charles de Oliveira, por ter sido com quem comecei a analisar material lítico e também por ter, com grande atenção, lido sem nunca se negar, grande parte desta dissertação, especialmente as análises dos sítios, ter corrigido e contribuído com sugestões valiosas;

- o professor Andre Prous, por ter sempre respondido meus e-mails com grande cordialidade e com textos muito elucidativos, me ajudando a entender questões importantes e sanar diversas dúvidas;

- Jacqueline Rodet, por sua humildade. Não esquecerei aquele dia, na SAB 2007 em Florianópolis, onde, ouvindo minha queixa por haver pouca gente em minha apresentação, às oito da manhã do primeiro dia do evento, e assim, não ter ninguém para me fazer críticas e dar sugestões, ela prontamente se dispôs a ver meus slides de PowerPoint. Pegou seu laptop, e junto comigo, sentada no chão da Universidade, ouviu tudo o que eu tinha a dizer e fez observações que saiba, me foram muito valiosas;

- a Música, porque sempre foi uma constante em minha vida, me servindo de refúgio e alento. Dela eu retiro a energia e me refaço de momentos estressantes. Ela me ajudou a passar por vários momentos difíceis, e não foi diferente na elaboração desse trabalho. Agradeço dessa forma a compositores que me inspiram como L. Beethoven, J.S. Bach, Paganini, G. Verdi, Vivaldi e os grandes músicos brasileiros, o Maestro Andre Matos e o grande mestre do Ritmo Ricardo Confessori. A influência e a obra de vocês foram fundamentais na construção do que sou;

- Solange Caldarelli, Lucas Bueno e Astolfo Araújo que foram influência constante no desenvolvimento deste trabalho; 
- o pessoal da biblioteca do MAE, sempre solícito e bem humorado, e também da secretaria, especialmente a Vanusa Gregório, por sua competência e atenção dedicada a todos;

- os meus tios Rosa de Almeida Grossi e Luiz Grossi e meus primos Luiz Paulo de Almeida Grossi e Solange de Almeida Grossi, que sempre demonstraram respeito e admiração pelo que faço, me incentivando e dando força;

- a Andrea Coutinho, pelo seu amor e carinho;

- Por fim, agradeço a CAPES, pelo auxílio com a bolsa de mestrado, e a minha orientadora professora Silvia Maranca, pela grande paciência que teve comigo ao longo desses anos.

- Deixo aqui minha gratidão a todos! 


\section{RESUMO}

A presente pesquisa pretende compreender a ocupação dos grupos caçadorescoletores na região central do Estado de São Paulo, na Bacia do Rio Tietê, em seu médio curso. Através da análise de três sítios líticos, dois na região de Araraquara e um na região de Jaú, realizamos estudos intra e inter-sítios, além da comparação dos resultados com trabalhos já realizados nas áreas adjacentes e também com a literatura específica. Destacando uma abordagem regional, buscamos trabalhar questões como intensidade de material arqueológico, estratigrafia, o tamanho dos sítios, a distância entre eles, como se deu sua implantação na paisagem; identificar as áreas de atividades restritas e a tecnologia da indústria lítica. A partir desses resultados, como intuito final, lançamos hipóteses sobre possíveis relações de contato entre os sítios, como os grupos caçadores-coletores se aproveitaram do ambiente nessa região, percebendo assim, sua mobilidade no território, e o tempo de ocupação.

Palavras-Chave: Caçadores-coletores, sistemas de assentamento, mobilidade, variáveis ambientais, centro oeste paulista, pré-história brasileira, cadeia operatória, sítios líticos. 


\section{ABSTRACT}

This research aims to understand the occupation of hunter-gatherers groups in the central region of São Paulo State, on Tietê River Basin, in its middle course. Through analysis of three lithic sites, two in the Araraquara Region and one in Jaú Region, we have done intra and inter-sites studies, beyond the comparison of results with work done in areas adjacent and also with the specific literature. Emphasizing a regional approach, we sought work issues such as intensity of archaeological material, stratigraphy, the size of sites, the distance between them, how occurred their settlement in landscape, identify the restricted areas activities and the technology of the lithic industry. From these results, we released hypotheses about possible relationships of contact between the sites, how hunter-gatherers

groups took advantage of the environment in this region, realizing thus, their mobility in the territory, and the time of occupation.

Key-words: hunter-gatherers, systems of settlement, mobility, environmental variables, center west paulista region, Brazilian prehistory, Operational Chain, lithic sites. 


\section{SUMÁRIO}

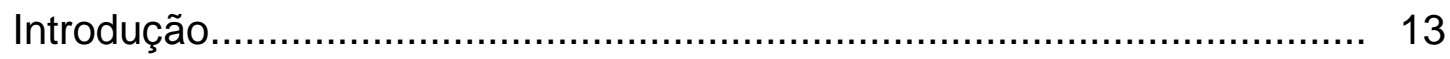

Capítulo I - Antecedentes.............................................................. 14

I.1. O Povoamento das Américas.......................................................... 16

I.2. Breve histórico dos estudos sobre os caçadores-coletores.................. 21

I.3. As pesquisas sobre os caçadores-coletores no Estado de São Paulo 25 (excetuando o litoral).

I.4. A região central do Estado de São Paulo: panorama etnográfico e histórico das pesquisas arqueológicas................................................ 30

Capítulo II - Bases Teóricas e Métodos de Pesquisa................................ 37

II.1. Detalhamento da pesquisa e colocação do problema......................... 38

II.1.1. A relação HOMEM \& AMBIENTE num aspecto regional.................. 38

II.1.2. Contribuição dos estudos bibliográficos para a compreensão da

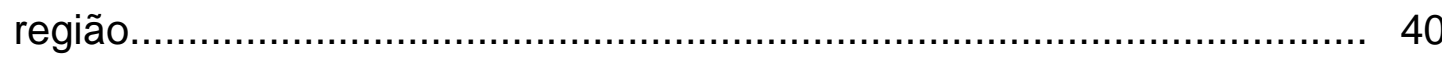

II.1.3. Os sistemas de assentamento na região central do Estado de São Paulo. 41

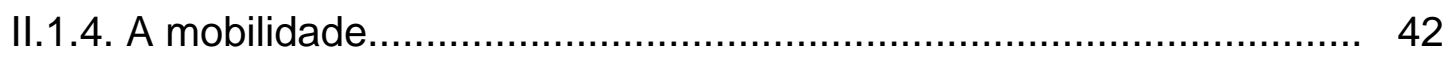

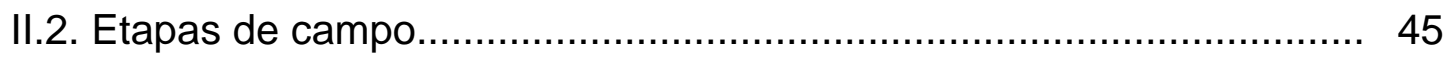

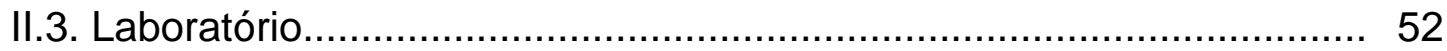

Capítulo III - Delimitação da área geográfica e características ambientais 55

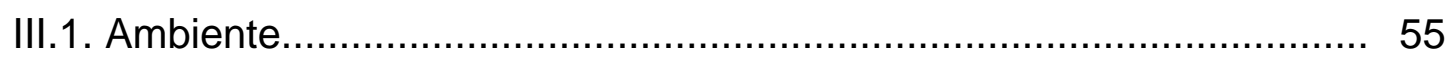

III.2. Geologia e geomorfologia..................................................... 56

Capítulo IV - Os sítios arqueológicos..................................................... 64

IV.1. A indústria lítica: tecnotipologia.................................................. 70

IV.2. Sítio Dois Córregos.................................................................... 76

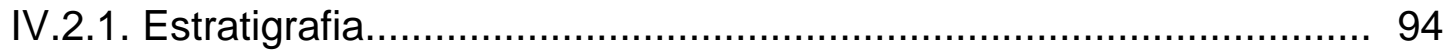

IV.2.2. Análise de dados................................................................. 94

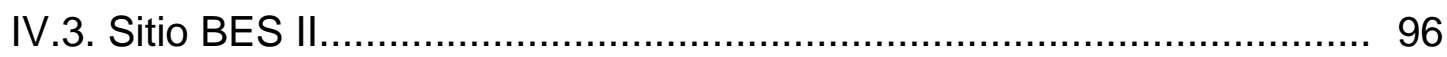

IV.3.1. Análise Vertical................................................................. 120 


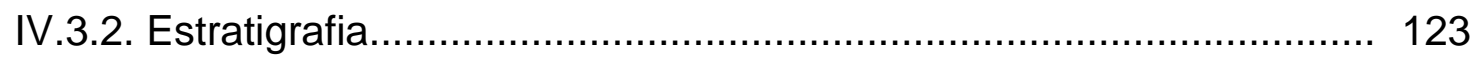

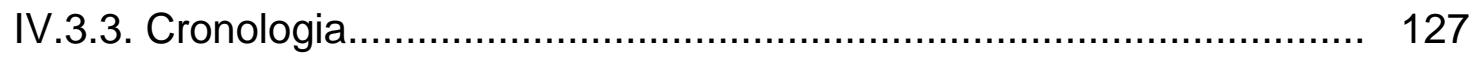

IV.3.4. Análise de Dados....................................................................... 127

IV.4. Sítio BES III..................................................................... 129

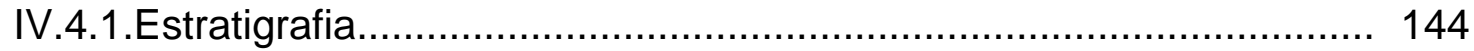

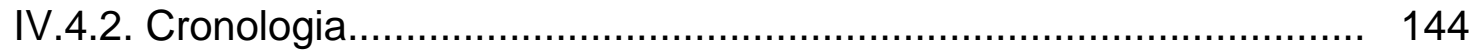

IV.4.3. Análise de Dados....................................................................... 144

Capítulo V - Sítios Líticos no Centro-Oeste Paulista................................. 145

V.1. Caçadores-Coletores no Interior Paulista........................................ 156

V.2. Caçadores-Coletores como parte da História do Interior

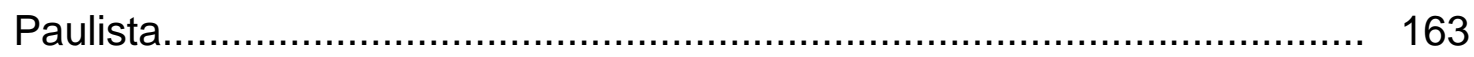

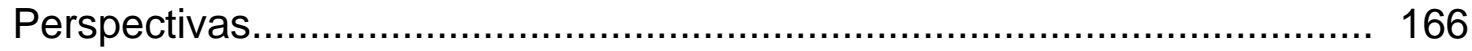

Referências bibliográficas.............................................................. 167

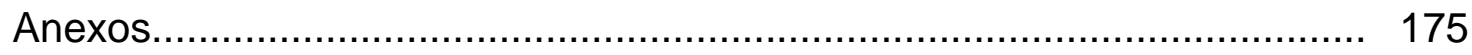

\section{LISTA DE MAPAS, PRANCHAS E IMAGENS}

1. Modelo de Ocupação da América do Sul - etapas de ocupação............ 20

2. Modelo de Ocupação da América do Sul - Fluxos migratórios............... 21

3. Mapa Geológico da Região Central do Estado de São Paulo................ 57

4. Mapa Geomorfológico da Região Central do Estado de São Paulo........ 58

5. Mapa Pedológico da Região Central do Estado de São Paulo................ 59

6. Mapa Hidrológico da Região Central do Estado de São Paulo............... 60

7. Afloramento arenítico em estrada de acesso a Boa Esperança do Sul... 61

8. Vista da área do Sítio BES II.......................................................... 62

9. Vista da área do Sítio BES III............................................................63

10. Vista da área do Sítio Dois Córregos................................................. 64

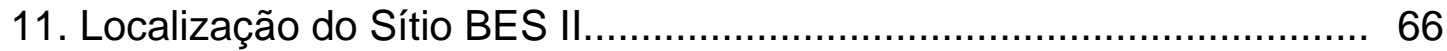

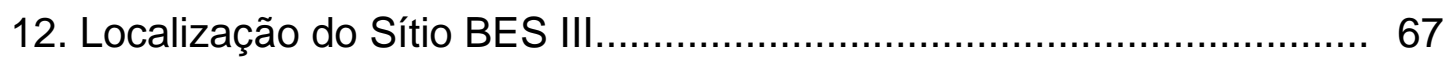

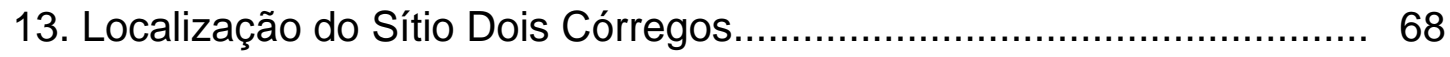

14. Mapa da Localização dos Sítios........................................................... 69 


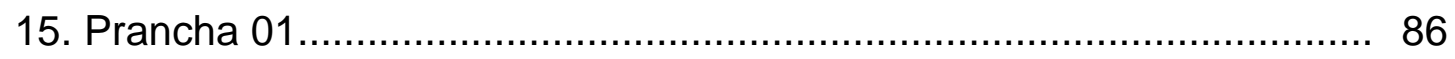

16. Prancha 02

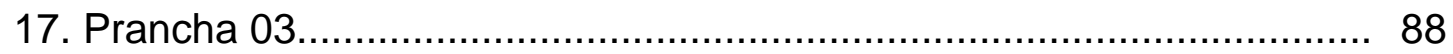

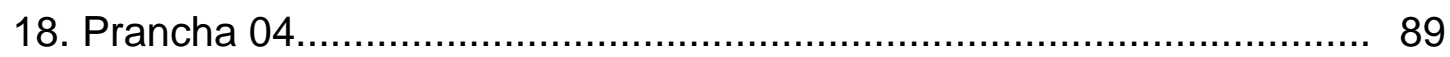

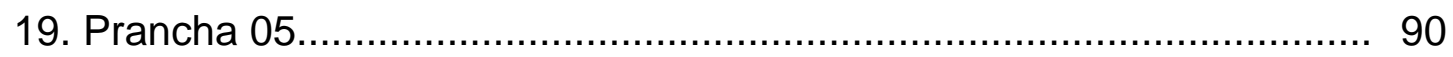

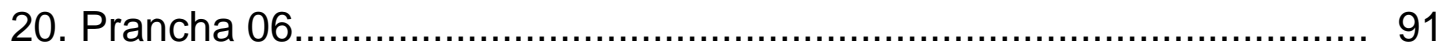

21. Delimitação das áreas de ocorrência de material arqueológico............ 92

22. Distribuição dos vestígios em superfície............................................... 93

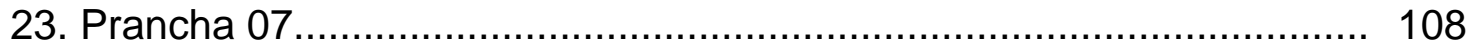

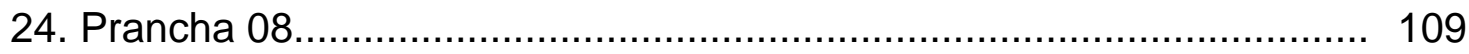

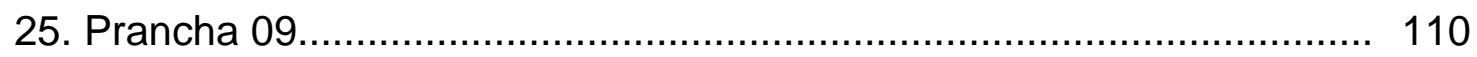

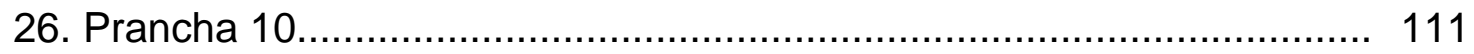

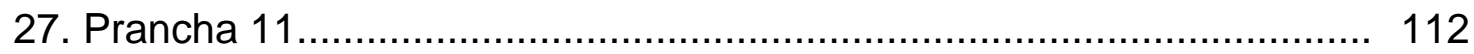

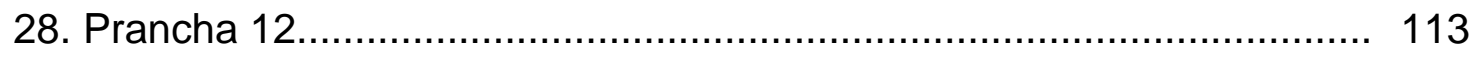

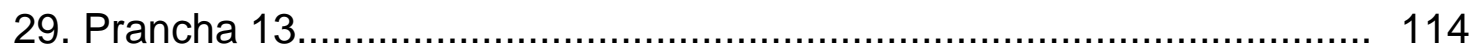

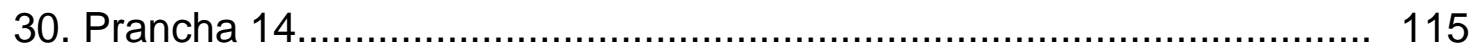

31. Intervenções Arqueológicas Sítio BES II - etapa 1........................... 116

32. Área de Coleta peça a peça........................................................... 117

33. Intervenções Arqueológicas Sítio BES II - etapa 2........................... 118

34. Intervenções Arqueológicas Sítio BES II - etapas 1 e 2..................... 119

35. Perfil Estratigráfico Unidade de Escavação 01 - Sítio BES II: etapa 2.. 125

36. Perfil Estratigráfico Unidade de Escavação 02 - Sítio BES II: etapa 2.. 126

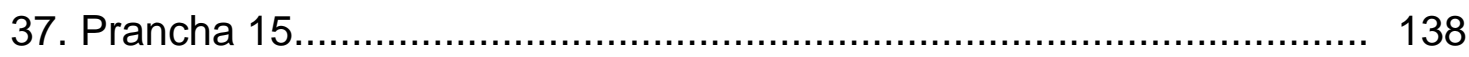

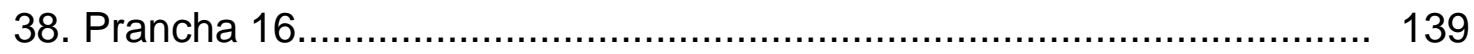

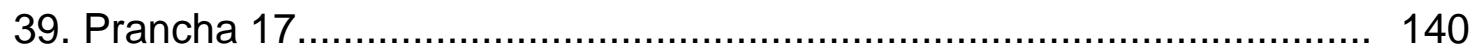

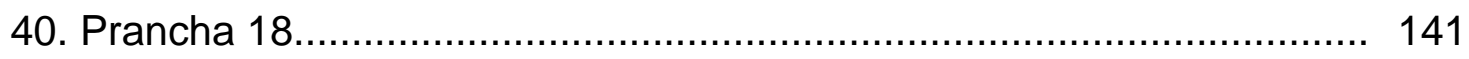

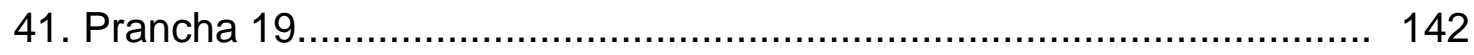

42. Intervenções Arqueológicas Sítio BES III - etapa 1........................... 143

43. Distribuição espacial das unidades geoecológicas ao longo na área

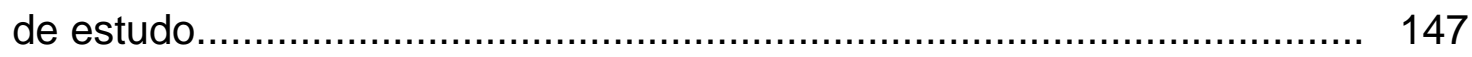

44. Contato dos basaltos e arenitos respectivos da formação 
litoestratigráfica Serra Geral e Botucatu na área de Rampas e Patamares

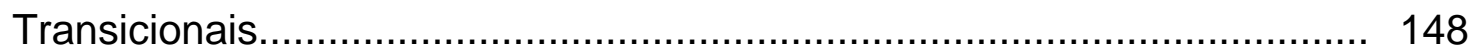

45. Localização do sítio BES II no limite entre as rampas e terras baixas do Jacaré.

46. clastos de basaltos encontrados em discreta saliência localizada da altimetria média das Terras Baixas do Rio Jacaré.

47. Mapa Relação de Sítios, Ocorrências Líticas e Afloramentos Areníticos na Região Central do Estado de São Paulo.

48. Mapa Sítios Caçadores-Coletores Datados no Interior Paulista. 158

49. Ações de Educação Patrimonial. 165

\section{TABELAS}

1. Achados Arqueológicos na Região Central do Estado de São Paulo..... 34

2. Intervenções arqueológicas no sítio BES II.................................. 47

3. Unidade de Escavação 01 - BES II / Fev 2010.............................. 49

4. Unidade de Escavação 02 - BES II / Fev 2010............................. 49

5. Descrição da Unidade de Escavação (1 x 1 m) - Sítio Dois Córregos.... 51 


\section{INTRODUÇÃO}

Na conhecida Conferência Man the Hunter, realizada em 1966 com o intuito de mostrar a importância da herança que as sociedades caçadoras-coletoras nos deixaram, foi ressaltado que desde o surgimento do "homem cultural” na Terra, aproximadamente há 2 milhões de anos, 99 por cento desse período, ele viveu como caçador-coletor. Apenas nos últimos 10.000 anos que o homem começou a domesticar plantas e animais, a usar metais e aproveitar outras fontes de energia fora o próprio corpo humano. 90 por cento de toda a população que já existiu foi caçadora-coletora, e apenas 6 por cento viveu da agricultura, enquanto que o restante constitui as sociedades industriais. Ou seja, "o modo de vida caçador-coletor tem sido a mais bem sucedida e persistente adaptação que o homem já alcançou” (Lee \& Devore, 1968: 3).

A importância do estudo dessas sociedades também se torna evidente quando tentamos compreender a ocupação humana no Continente americano e por conseqüência, suas diversas regiões, inclusive o Brasil. Diminuindo a escala, para podermos entender como se deu a ocupação humana no Estado de São Paulo são necessários estudos mais aprofundados sobre esses grupos no território.

Nos últimos anos, especialmente a partir do ano de 2002, com a portaria 230 do Iphan $^{1}$, os trabalhos arqueológicos vinculados aos estudos de impacto ambiental tem ganhado grande força. Desde então, por conta desses trabalhos, o número de sítios arqueológicos identificados em todo o país sido muito altos. Na atual conjuntura, 98\% da Arqueologia feita no território brasileiro está vinculada a esses projetos. Dos sítios detectados no território paulista nesses últimos anos, grande parte são sítios líticos, dispersos por todo o Estado. Esse fato vem justamente reforçar a necessidade do estudo dessa categoria de sítios, normalmente associada aos grupos caçadores-coletores.

\footnotetext{
1 Esta portaria vem disciplinar de forma clara os procedimentos arqueológicos a serem executados por qualquer requerente que deseje realizar empreendimentos potencialmente causadores de danos a matriz finita do Patrimônio Cultural Arqueológico. A norma esta didaticamente subdividida em obrigações segundo o ordenamento do Licenciamento Ambiental e assim compatibilizam os interesses das esferas públicas na proteção do Ambiente Cultural (Normas e Gerenciamento do Patrimônio Arqueológico, 2005: 48).
} 
Foi com o intuito de contribuir para o esclarecimento das questões que o quadro expõe que se realizou este trabalho.

No primeiro capítulo é feito um breve histórico dos estudos sobre os grupos caçadores-coletores, seguido de uma apresentação das informações que se têm atualmente sobre a ocupação do continente americano como um todo. É feito um histórico das pesquisas de caçadores-coletores no Estado de São Paulo e seu contexto etno-histórico e arqueológico em sua região central.

No Segundo capítulo justificamos nosso olhar sobre o objeto de estudo através das bases teóricas e metodologia utilizada na pesquisa de campo e laboratório.

No terceiro capítulo é feita a caracterização ambiental da área de pesquisa.

No quarto capítulo são apresentados os sítios arqueológicos que foram alvos de nosso estudo, bem como a análise tecnotipológica de seu material lítico.

Em seguida, no quinto capítulo, é feita a análise do conjunto dos sítios trabalhados, bem como sua inserção no contexto arqueológico regional. São apresentadas as hipóteses e questionamentos levantados com os trabalhos de campo e laboratório, de acordo com a comparação bibliográfica, além de uma pequena apresentação do trabalho de educação patrimonial realizado nas cidades envolvidas durante o processo de elaboração desta dissertação.

Por fim, no capitulo de conclusão, são apresentadas as perspectivas quanto a continuidade das pesquisas realizadas até então.

\section{CAPÍTULO I - ANTECEDENTES}

Seguindo a atual tendência de revisitar a História do Brasil e direcionar o foco de análise para outras questões que foram pouco discutidas, destaca-se um olhar mais atento para o Brasil Pré-Colonial. Para conhecermos a História depois da chegada de Cabral faz-se uso, sobretudo, de documentos escritos, e através deles obtemos informações sobre tal período. Contudo, a fase que precede esse momento, ou seja, a época em que os europeus ainda não tinham entrado em contato com terras brasileiras, não dispõe dessa fonte. Assim sendo, devemos considerar que para se estudar o passado seja necessário discutir duas questões: as fontes históricas de que dispomos e as teorias sociais que podemos agenciar na 
interpretação delas. Quanto ao estudo das sociedades podemos usar uma variedade de modelos sociológicos ou antropológicos (Funari \& Carvalho, 2005). Entretanto, o único testemunho que temos sobre os povos que habitaram essas terras, é o de sua cultura material. Nesse caso, o meio mais seguro para se conseguir extrair algum tipo de informação é o estudo arqueológico. Vale ressaltar aqui, que entendemos por "cultura material” todo e qualquer objeto produzido pelas sociedades humanas, considerando também os testemunhos de sua cultura que possam ter deixado, como escrituras e grafismos em rochas (blocos, paredões de abrigos, etc.) ou paredes, edificações de qualquer gênero, e toda a apropriação da natureza que se dá sempre nos quadros de uma determinada organização social com um potencial produtivo definido (Funari, 1988). E o objetivo principal do estudo dessa cultura material é compreender seu produtor, ou seja, o homem e seu comportamento. Para isso, devemos entender o conceito de Cultura. O termo Cultura, pelo menos como é utilizado atualmente, foi definido pela primeira vez por Edward Tylor, que pelo vocábulo inglês "culture", considera que, "tomado em seu amplo sentido etnográfico é este todo complexo que inclui conhecimentos, crenças, arte, moral, leis, costumes ou qualquer outra capacidade ou hábitos adquiridos pelo homem como membro de uma sociedade" (Tylor, 1871).

O estudo das populações ameríndias faz-se extremamente necessário, visto que nos deixaram um legado considerável, que hoje faz parte da cultura brasileira, e compreendêlos melhor ajudará a nos entender um pouco mais. Essa é a importância de conhecer o passado, pois "a postura que adotamos com respeito ao passado, quais as relações entre passado, presente e futuro não são apenas de interesse vital para todos: são indispensáveis.(...) Os historiadores são o banco de memórias da experiência. Teoricamente, o passado - todo o passado, toda e qualquer coisa que aconteceu até hoje constitui história.... O que a história pode fazer é descobrir os padrões e os mecanismos da mudança histórica em geral, em lugar de previsões e esperanças, é isso que é diretamente relevante para a sociedade contemporânea e suas perspectivas”(Hobsbawn, 1998). Reforçamos essa idéia com Vavy Pacheco Borges ao afirmar que "a função da História, desde seu início, foi a de fornecer à sociedade uma explicação sobre ela mesma” (Borges, 1993:49). A partir dessa perspectiva, tentamos resgatar um momento de nossa História que por muitos passa despercebido, mas que merece atenção especial por tratar-se dos primeiros 
colonizadores do continente americano e também, por que não, indiretamente, nossos ancestrais. Afinal, o povo brasileiro é fruto da miscigenação, que "ocorreu desde os primeiros momentos da conquista. Brancos e índios geraram mamelucos em Pernambuco, Bahia, Rio de Janeiro e sobretudo São Vicente, no século XVI. No século XVII o mesmo se verificou no Estado do Maranhão, bem como nas demais capitanias” (Wehling \& Wehling, 1999:228).

\section{I.1.) O Povoamento das Américas}

Para entendermos um pouco essa dinâmica, devemos aprofundar um pouco os conhecimentos a respeito do povoamento do continente americano. A teoria até agora consagrada sobre a chegada do homem na América é a da passagem pelo estreito de Bering. Lugar que teria atravessado seguindo as grandes manadas de animais que migravam em busca de alimentação. Essa passagem foi possível com a formação da Beringia ${ }^{2}$. No entanto, nem sempre ela era possível por conta das grandes formações glaciais que impediam o acesso para a América. Somente quando as formações glaciares recuavam, formando o "Ice-free-corridor" é que a entrada se tornava possível, e a última vez em que esse fenômeno ocorreu foi entre 20.000 e 13.000 anos atrás.

Sabe-se, até agora, que os primeiros povos que ocuparam o Brasil - já Homo sapiens sapiens - foram os paleoíndios. Estes ocuparam as Américas antes de 10.000 anos A.P. podendo ir até 50.000 anos A.P., assim como demonstram as pesquisas realizadas no Sítio Boqueirão da Pedra Furada no Piauí. O primeiro sítio escavado profissionalmente no Brasil, na década de 1970, que mostrou evidências de que esses homens pleistocênicos poderiam estar na América antes de 11,4 mil anos - contrariando a teoria Clovis-first ${ }^{4}$ - foi o Lapa Vermelha IV em Minas Gerais, escavado por Anette Laming. O sítio onde foi encontrado o esqueleto de Luzia, que gerou a data de 11,5 mil anos. Ainda nesta década, na

\footnotetext{
${ }^{2}$ Faixa de terra que emergiu entre o Alaska e a Sibéria durante os períodos de glaciação.

${ }^{3}$ Corredor livre de gelo

${ }^{4}$ Cultura Clovis foi a cultura material produzida por uma população que dispunha de uma tecnologia de fabricação de pontas de flecha (ou lanças) bastante desenvolvidas, caracterizadas por uma estria ou canaleta criada pela remoção de uma lasca da superfície mais baixa, em uma ou ambas as faces. Essa cultura é datada entre 11.500 e 10.500 anos, e até pouco tempo considerada como representante das primeiras populações a entrar no continente americano, sendo essa teoria norte-americana pouco questionada. Por isso o termo “Clovis-First” (DE BLASIS, P.D. Brasil 50 mil anos: uma viagem ao passado pr-e-colonial. Guia temático para professores, MAE/USP).
} 
Colômbia, vários abrigos sob rocha escavados por Gonzalo Correal, nas cercanias de Bogotá, forneceram datas pré-clovis, algumas por volta de 12 mil anos, como no caso dos sítios El Abra e Tibitó. Na Argentina, o Sítio Piedra Museo, escavado por Laura Miotis, da Universidade Nacional de La Plata, também alcançou níveis - supostamente antrópicos datados de cerca de 12 mil anos. Mas para esses últimos sítios a falta de recursos possibilitou poucas datações, o que compromete a aceitação dessas idades. Essas datas mais recuadas, especialmente as do Piauí, são ainda muito discutidas por tratar-se de fatos isolados, todavia, elas têm instigado mais estudos, e por conta disso, a partir da década de 1990 começam a aparecer várias datas consideradas “pré-clovis”. Assim, surgem sítios como o Abrigo Pedra Pintada, no Pará, com 11,3 mil anos, estudado por Ana Roosevelt; Monte Verde no Chile, escavado por Tom Dillehay, com 13 mil anos, além de outra data para o mesmo sítio de 33 mil anos - contudo, essa é questionada pelo próprio autor (Araújo, 2004 e Guidon, 2005). Também temos o sítio Old Crow no Alasca, com 14 mil anos, o sítio Taima Taima, famoso sítio venezuelano de megafauna, onde foram encontrados fragmentos de pontas raras em forma de folha de ouro, com datações entre 14.400 e 11.900 anos. No Peru, existem numerosas datações radiocarbônicas para sítios com pontas triangulares, outros instrumentos e restos de fauna e flora modernas entre 11 mil e 7.100 anos A.P. nos altiplanos, e entre 10.400 e 7.700 na costa. Importantes enterramentos foram recuperados em sítios relacionados à cultura Paijan da costa norte, com datações de 11 mil e 9 mil anos. Há ainda Valsequillo no México, com data de 29.000 anos e mais recentemente o sítio Topper, na Carolina do Sul, Estados Unidos, onde as escavações realizadas pela equipe chefiada por Albert Goodyear permitiram descobrir, em 2004, datações com mais de 16 mil anos. A cerca de 2 metros abaixo da camada da qual havia vestígios da cultura Clovis, foram encontrados utensílios de pedra lascada e carvão, o qual, analisado pela técnica do carbono 14 forneceu resultados de 50.300 e 51.700 anos. Segundo Niède Guidon, tais sítios parecem indicar que houve uma primeira migração de Homo sapiens vindo da Europa ou da África, isso por estarem mais próximos do oceano Atlântico, fato que, se comprovado atestaria que o Estreito de Bering não foi a única via de entrada no continente (2005). No Brasil central, no Estado de Mato Grosso, o sítio Santa Elina também revelou uma datação de 25.000 anos A.P. Foi ainda um dos poucos casos na América do Sul (acanhados exemplos na Terra do Fogo, na Patagônia, na Sabana de Bogotá 
e no norte da Venezuela), primeiro e único no Brasil onde se comprovou a co-existência entre o homem e a megafauna ${ }^{5}$, pois no último estrato da escavação foram encontrados restos faunísticos com nítidas intervenções humanas: um agrupamento de osteodermos de Glossotherium Letsomii (preguiça gigante) com marcas de fratura por aquecimento e 2 osteodermos com faces abrasadas, dando-lhes uma simetria e apagando as características típicas e diferentes de cada face do osteodermo. (Vialou, 2005).

Esses povos pioneiros eram sociedades caçadoras-coletoras, compostas por grupos, com média de 25 pessoas, que viviam basicamente de caça, pesca e coleta de alimentos silvestres, e por isso eram, em geral, nômades - sem avançar aqui, nas discussões acerca de nomadismo, sedentarismo e semi-nomadismo . Embora essa seja uma descrição simplista desses grupos e bastante debatida, é a que mais tem sido usada para ilustrá-los -. O principal testemunho dessas sociedades é o material lítico, ou seja, a rocha lascada, seu principal utensílio, podendo ser usada como furador, percutor, machado, ponta de projétil (flecha, lança, dardo), dentre outros. Mas em alguns casos também podemos encontrar artefatos feitos em ossos, chifres e conchas, além da arte rupestre.

No período de 12.000 anos A.P. essas populações já se encontravam espalhadas pelo território brasileiro, isso é o que nos mostra a grande incidência de sítios apontando essas datas. Há mais ou menos 10.000 anos atrás grandes mudanças climáticas globais ocorreram, mudando de forma drástica o ambiente no Brasil e fazendo com que as sociedades paleoíndias também se modificassem. Os grandes mamíferos e as grandes manadas deixaram de existir, e a nova paisagem que se instalava deu lugar a novos grupos de caçadores-coletores que se adaptaram as mudanças, refletindo isso em sua cultura material. Assim percebe Pallestrini ${ }^{6}$ (1987), pois para ela o homem pré-histórico instalou-se de diferentes maneiras em espaços favoráveis à sua economia, seguindo padrões culturais que se desenvolveram e criaram suas especificidades ao longo do tempo. A ocupação de um determinado espaço habitacional, segundo a autora, decorre de uma habilidade de

\footnotetext{
${ }^{5}$ Animais de grande porte como o Megatherium e Glossotherium (preguiça gigante) e Smilodon (tigre-dentesde-sabre). Habitaram a América até a época do ótimo climático, quando o clima mudou de mais frio e seco para mais quente e úmido. Os cerrados foram dando lugar as matas tropicais, e assim, os animais de menor porte foram ganhando mais espaço.

${ }^{6}$ Observar artigos de Luciana Pallestrini intitulado "O Cenário de sete mil anos”, publicado em Ciência Hoje, SBPC vol.4 n¹9 e o artigo "O espaço habitacional em pré-história brasileira” publicado na Revista do Museu Paulista, vol. XXV.
} 
escolha junto ao meio natural. Este meio selecionado é escolhido através de uma série de operações decorrentes das necessidades da espécie.

Com os dados de que dispomos hoje, ainda é difícil precisar quando e como os homens entraram na América, assim como quem eram os primeiros americanos. Até pouco tempo acreditava-se, a partir dos estudos dos indígenas atuais, que estes tinham afinidade genética com populações mongolóides do extremo oriente. Entretanto, os achados de restos humanos mais antigos - entre 10.000 e 12.000 anos - parecem indicar que houve outra leva de colonizadores. Esses primeiros grupos teriam maior afinidade com uma população proto-australóide, que vivia na Ásia, e da qual sairia um grupo que ocuparia a Austrália dando origem aos aborígenes australianos, enquanto outro ramo seria o primeiro a ir para a América. Para Walter Neves e Luís Beethoven Piló, esses grupos - a raça de Luzia - teriam chegado ao Novo Mundo antes de 11,4 mil anos, mas não muito antes. Seguindo a idéia de Anna Roosevelt, eles teriam chegado em torno de 13 e 14 mil anos atrás (2008). Astolfo Araújo concorda com a essa visão, contudo, não descarta que esse advento possa ter se dado bem antes, e ainda, da mesma forma que Walter Neves, conclui que a colonização se deu de forma bastante rápida, pois ambos acreditam ser muito mais plausível que essa expansão tenha ocorrido de forma mais ampla por vias costeiras e não pelo interior como vem se afirmando. Em estudos paleoambientais, os pesquisadores têm comprovado que no litoral, além das faixas contínuas de terra, mais fáceis de seguir caminhando, ou mesmo pela navegação de cabotagem, o clima era bem mais ameno que o interior. Este, ainda, oferecia uma série de dificuldades de relevo e vegetação para ser transposto. Para dar suporte a essa teoria, a existência do suposto corredor livre de gelo também vem sendo questionada e os sítios mais antigos da América do Norte não se encontram nessa área e sim, na parte mais leste do mesmo continente (Araújo, 2004).

Finalizando, por volta de 4.000 anos atrás essas sociedades caçadoras-coletoras já tinham consolidado sua ocupação nos quatro cantos do que viria a ser o Brasil, e desenvolvendo características distintas, contribuíram para a grande variedade cultural das sociedades indígenas americanas. 


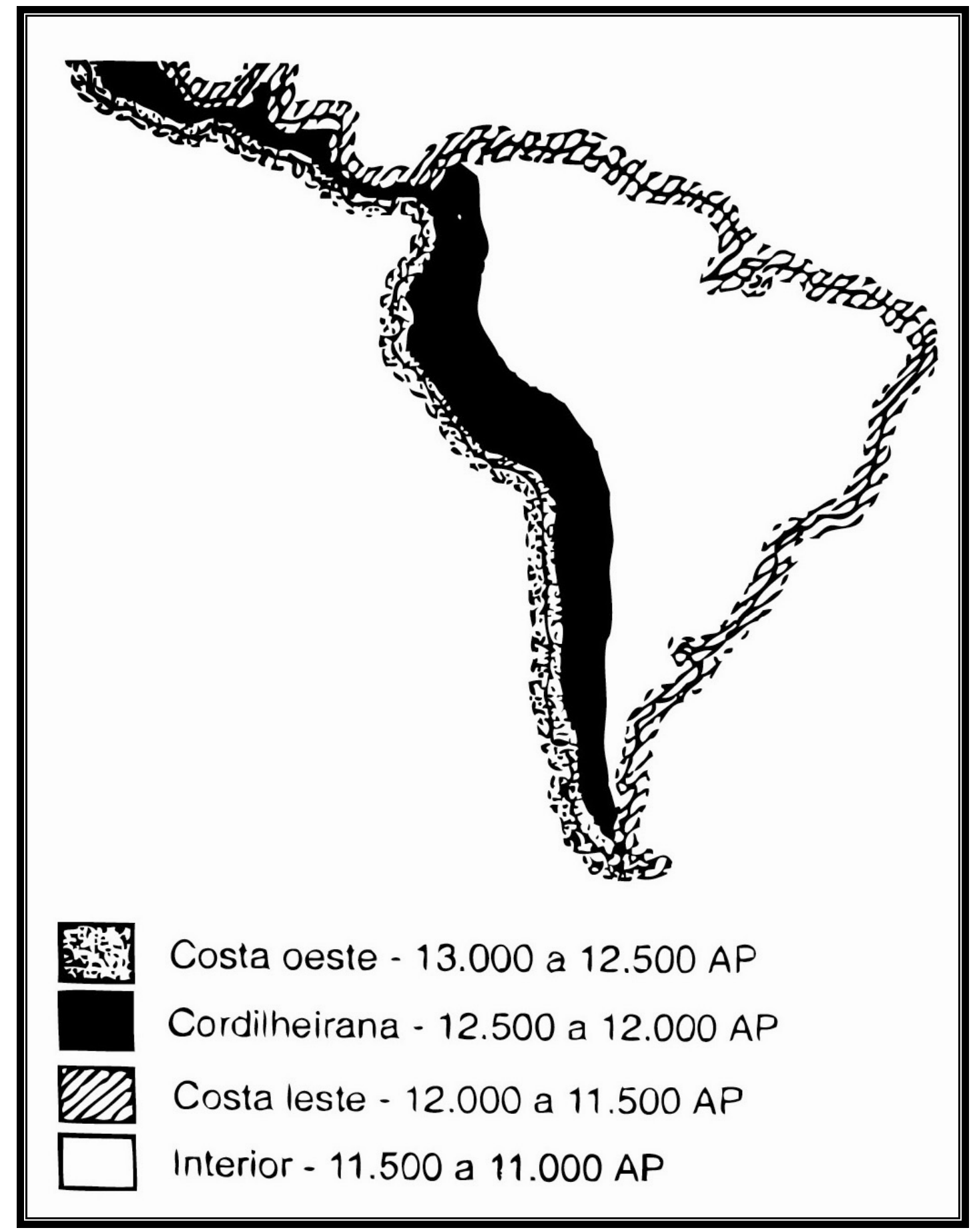

Imagem 01: Modelo de Povoamento da América do Sul de Dixon (1999, 2001 apud Araújo, 2004). São indicadas quatro etapas de ocupação, sendo que a mais antiga se daria ao longo da costa do Pacífico, seguida por uma interiorização andina. A costa Atlântica só teria sido ocupada mais recentemente. 


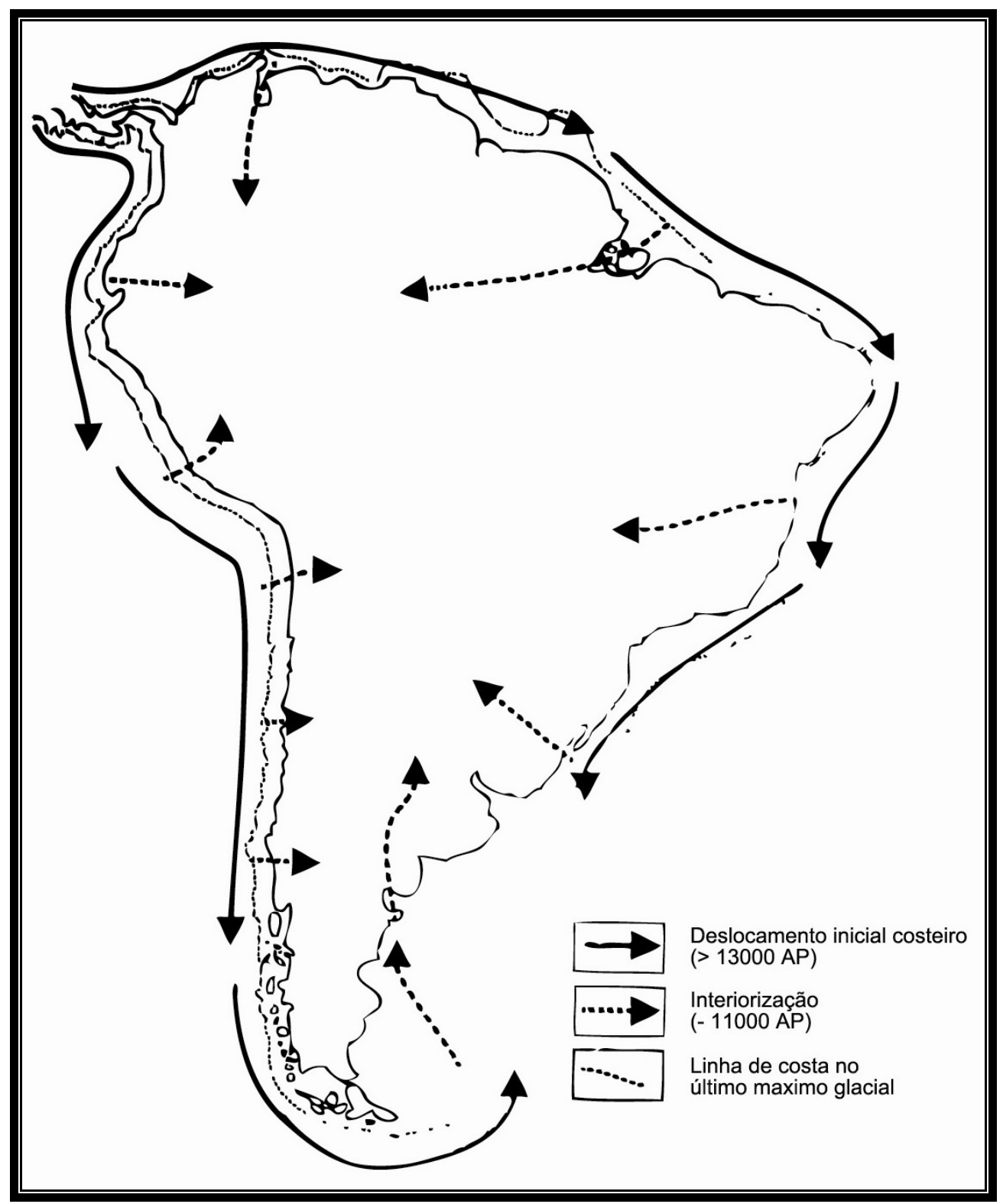

Imagem 02: Modelo de Povoamento da América do Sul considerando uma dispersão inicial pela costa, mas seguindo dois rumos, um pelo Atlântico e outro pelo Pacífico. A ocupação efetiva do interior do continente se daria mais tardiamente. Note-se que grandes extensões da antiga linha de costa estão hoje submersas (Araújo, 2004).

\section{I.2) Breve histórico dos estudos sobre os Caçadores-coletores}

Todos os dados aqui apresentados evidenciam a importância de se realizar estudos sobre as sociedades caçadoras-coletoras, especialmente no continente americano. 
Historicamente, os estudos etnológicos sistemáticos sobre as sociedades caçadorascoletoras se iniciaram no século XIX, tendo como base as teorias do evolucionismo social. Pensadores como Edward Tylor (1871) e Lewis H. Morgan (1877) basearam-se nas teorias de Charles Darwin (1859) e Charles Lyell (1863) para propor modelos de evolução cultural e social da humanidade, estudando as sociedades coletoras ainda existentes. De acordo com esses modelos evolucionistas o homem moderno teve que passar por estágios evolutivos. Foi proposta uma evolução linear do homem por meios de estágio e evolução biológica: selvageria, barbárie e civilização (Clark, 1985 apud Oliveira, 2007). O conceito de sociedade Caçadora-coletora foi usado pela primeira vez em 1911 por William Sollas (Lee \& Daly, 1999) e foi criado com base nas sociedades caçadoras-coletoras atuais e em registros arqueológicos de grupos caçadores-coletores do passado. Ainda no século XIX, surge paralelamente ao evolucionismo, o modelo difusionista, que procura explicar o desenvolvimento cultural por meio de processos de difusão de elementos culturais de uma cultura para outra, como negociação, imitação e conquista militar. $O$ auge desse pensamento se deu entre os anos de 1900 e 1930. O modelo difusionista, influenciou outra linha pesquisa, baseada em uma visão histórica, que culminou na criação de conceitos de áreas culturais.

Surge assim, em fins do século XIX e início do XX a escola Histórico-Cultural norte-americana, que apresentando novos conceitos como, "traço cultural”, “complexo cultural”, “padrão cultural” e “área cultural”, se contrapunha ao evolucionismo social. Seu maior representante foi Franz Boas (1858 - 1942), entre 1915 e 1930. Foi sua uma das primeiras críticas ao evolucionismo, que não aceitava o método dedutivo, segundo o qual, quaisquer semelhanças entre diferentes populações, humanas ou não, era associada a uma origem comum. Boas questionava se o método dedutivo não poderia ser substituído pelo indutivo empírico, no qual o pesquisador deveria ir a campo e coletar o maior número possível de informações sobre a sociedade estudada, através de uma descrição minuciosa de suas expressões culturais. Seu método defendia o particularismo histórico (Oliveira, 2007).

Ainda nessa fase, na Europa, Bronislaw Malinowisk começa a desenvolver suas pesquisas usando o método de campo participativo. Junto com Boas, cria o conceito da Etnografia moderna. No decorrer dessa trajetória, da estruturação da Antropologia enquanto Ciência surgem pesquisadores que vão complementar o corpo teórico acerca dos estudos 
sobre os grupos caçadores-coletores. Nomes como Émile Durkheim e Marcel Mauss, seguidos de Alfred Radcliffe-Brown destacam as particularidades de cada sociedade e atentam ainda mais para os trabalhos de campo, enfatizando a "conduta humana" para se entender a sociedade. Assim como entra em pauta também a analogia com os conceitos biológicos de organismo e vida.

A partir de 1930, os estudos sobre caçadores-coletores serão influenciados pelos pensamentos de Radcliffe-Brown e Julian Steward, que redefine o conceito de horda como bando patrilinear ${ }^{7}$ (Lee \& Daly, 1999 apud Oliveira, 2007). Em seu trabalho, The Social and Economic Basis of Primitive Bands de 1936, Steward realiza o primeiro estudo sistemático sobre sociedades caçadoras-coletoras da Antropologia norte-americana (Kelly, 1995). Através de seus estudos Steward desenvolve sua teoria de mudança cultura, postulando três tipos de organizações de bandos primitivos que viriam nortear os estudos de caçadores-coletores pelo mundo. São os bandos patrilineares, matrilineares e compostos.

Por sua vez, Elman Rogers Service, na década de 1960, acreditava que os bandos patrilocais ${ }^{8}$ foram a primeira forma de organização da História humana, ou seja, a base de organização social de todos os grupos caçadores-coletores. Ele pensava o estudo das sociedades caçadoras-coletoras com base em uma evolução social, como bando, tribo, cacicado e estado primitivo. Baseando-se nessas idéias, com o tempo, o termo "bandos patrilineares” passou a ser sinônimo de “caçadores-coletores”.

Entre as décadas de 1930 e 1960, os estudos etnográficos deram ênfase aos sistemas de parentesco ou de estrutura social das sociedades com os modelos de Radcliffe-Brown (1931) e Julian Steward (1936), até que, de acordo com o crescente interesse pelo estudo das sociedades caçadoras-coletoras, acontece em Chicago, Estados Unidos, em 1966, a Conferência Man the Hunter, que viria a influenciar diversas gerações de pesquisadores. Foram propostos modelos a partir de estudos etnográficos realizados na África, Austrália, Subártico, América do Sul e do Norte. Foi acrescentada uma nova roupagem para o estudo dos caçadores-coletores abordando questões relacionadas a práticas econômicas, mas sem

\footnotetext{
${ }^{7}$ Relativo à sucessão por linha paterna - Dicionário Escolar da Língua Portuguesa. Ministério da Educação e Cultura. 11 $1^{\mathrm{a}}$ Ed./7 Tiragem. Rio de Janeiro, 1983.

${ }^{8}$ Relativo à Instituição segundo a qual, a mulher, pelo casamento, é obrigada a seguir o marido, passando a morar na localidade dele - Dicionário Escolar da Língua Portuguesa. Ministério da Educação e Cultura. 11a Ed./7ª Tiragem. Rio de Janeiro, 1983.
} 
perder o viés social (Oliveira, 2007: 19). Nessa Conferência definiu-se o “estilo nômade” com base em cinco características principais:

1. Igualitarismo;

2. Baixa densidade populacional;

3. Ausência de Territorialidade;

4. Um mínimo de estocagem de alimentos;

5. Fluidez na composição do bando.

Um grande destaque nessa conferência foi Marshall Sahlins, que em seus estudos definiu o modelo da "sociedade de afluência original", , onde a sociedade da caça e coleta seria a primeira sociedade da afluência. Assim, pelo senso comum, seria uma sociedade em que todas as vontades materiais das pessoas seriam facilmente satisfeitas (Sahlins, 1972). Esse conceito se torna muito forte em um momento que se refletia a sociedade industrial e consumista de então, que encarava a trajetória humana como algo pessimista, onde sempre havia a submissão ao trabalho árduo.

Na Conferência Man the Hunter foi reconhecida a imensa variabilidade entre os caçadores-coletores, mas ainda assim persistiram em sistematizar os estudos através de modelos universais.

Nas décadas de 1980 e 1990 surgiram as primeiras críticas a essas idéias, destacando, assim, uma abordagem baseada nas relações entre cultura e ambiente. Nasce nesse momento, a Ecologia Cultural ou Antropologia Ecológica, baseada no NeoEvolucionismo norte-americano (Kelly, 1995).

Com o objetivo de dar continuidade as discussões levantadas, surgem as Conferências mundiais sobre os grupos Caçadores-Coletores, que ficaram conhecidas mais tarde como CHAGS - “Conference on Hunting-And-Gathering Societies”10. Após a Man the Hunter tivemos mais nove conferências: uma em Paris (1978); outra em Quebec (1980); Bad Homberg, Alemanha (1983); Londres (1986); Darwin, Austrália (1988); Fairbanks (1990); Moscou (1993); Osaka (1998); Edinburg (2002). Enquanto as seis primeiras foram dominadas pelos modelos ocidentais, a partir da sétima conferência - em Moscou -, um maior número de tradições antropológicas passou a ser representado (Barnard, 2004).

\footnotetext{
${ }^{9}$ Abundância.

${ }^{10}$ Conferência sobre Sociedades Caçadoras-Coletoras - todas as traduções aqui apresentadas são feitas pelo autor deste trabalho, portanto, são de sua inteira responsabilidade.
} 
Em um ensaio apresentado na 6 ${ }^{\mathrm{a}}$ edição do CHAGS (Fairbanks, 1990), Richard Lee mencionou brevemente seis questões-chave nos estudos (sobretudo Ocidentais) sobre coletores-caçadores desde os anos 60:

- evolucionismo;

- estratégias otimizadas de "forragear"11;

- a mulher coletora;

- visão de mundo e análise simbólica;

- coletores-caçadores na pré-história;

- coletores-caçadores na história (Lee 1992: 32-3 apud Barnard, 2004).

A partir dos estudos atuais sobre as sociedades caçadoras-coletoras, a preocupação com a sobrevivência dos grupos ainda existentes e a garantia de seus direitos se faz presente, e assim, Alan Barnard (2004) acrescenta uma sétima e uma oitava questão, além das seis levantadas por Lee: relações com forasteiros/estrangeiros e vozes indígenas. Também vale destacar que a partir da inclusão de outras visões fora do mundo Ocidental, como de estudiosos da Índia (ex: Shanti Pappu), Rússia (ex: Anna Sirina) e Japão (ex: Mitsuo Ichikawa e Kazuyoshi Sugawara), novas interpretações sobre os grupos caçadorescoletores vêm sendo feitas.

\section{I.3) As pesquisas sobre os Caçadores-coletores no Estado de São Paulo (Excetuando o} Litoral)

Sobre os estudos das sociedades Caçadoras-coletoras no Estado de São Paulo, verificamos que a pesquisa voltada a esse tema chama a atenção dos profissionais a partir da década de 1960 (Guidon, 1964; Silva 1967 e 1968; Palestrini, 1968, Miller, 1968, 1969). Em 1964, a equipe de Arqueologia do Museu Paulista, sob a coordenação de Niède Guidon, realizou pesquisas no vale do Rio Pardo e Mogi-Guaçu. As prospecções resultaram na localização dos sítios arqueológicos Fazenda Ribeiro e Jataí, sendo ambos caracterizados pela presença de material lítico. Em 1968, a mesma instituição, liderada pela arqueóloga Luciana Pallestrini dá início ao Projeto Paranapanema que revelou perto de 12 sítios

\footnotetext{
${ }^{11}$ Do inglês: Foraging - não há tradução exata, mas numa aproximação, seria o ato de buscar comida.
} 
arqueológicos, especialmente em torno da região polarizada de Piraju. A maioria dos sítios encontrados foi classificada como "lito-cerâmicos colinares do interior", contudo dentre eles estão presentes alguns líticos, dos quais 3 - Almeida, Camargo e Brito - contam com descrições mais detalhadas da indústria lítica. Ainda nessa década, começa a ser estudada a região de Rio Claro, onde supostamente estão os sítios arqueológicos mais antigos do Estado. Na verdade, desde 1959, Altenfelder Silva, então professor da Faculdade de Filosofia e Letras de Rio Claro, inicia com seu assistente, Tom O. Miller Jr., prospecções na área. Dando continuidade às pesquisas (Becker,1966; Silva, 1967 e 1968), Tom O. Miller Jr. desenvolveu estudos na Bacia de Rio Claro. O arqueólogo identificou inúmeros sítios arqueológicos que foram associados às tradições Ipeúna e Rio Claro e às fases Monjolo Velho, Santo Antônio e Marchiori. A Tradição Ipeúna foi reconhecida como a mais antiga, situada em paleopavimentos ou em terraços fluviais, correspondendo à populações adaptadas a vida florestal. A Tradição Rio Claro foi associada às populações adaptadas às atividades de caça em ambiente de estepe ou savana, localizadas nos baixos terraços e nos solos recentes. A datação mais antiga obtida para a chamada "Tradição Rio Claro” foi de 5.330 a 5.140 A.P. Mas é a partir das décadas de 1970 (Miller 1972; Beltrão, 1974 e 2000; Uchôa \& Garcia, 1976) e 1980 (Pallestrini e Morais, 1982 e 1983; Uchôa \& Garcia, 1988) que as pesquisas são feitas com mais intensidade, de forma sistemática. A análise do material do sítio Alice Böer e da coleção Gualter Martins identificado em 1965 por Maria C. Beltrão levou a pesquisadora a propor dois horizontes culturais, sendo o mais antigo, pré-ponta de projétil e o segundo, mais recente, caracterizada pela presença das pontas de projétil, vinculadas a grupos caçadores. Assentado em um terraço fluvial e com uma estratigrafia de 4 metros, este sítio foi datado por termoluminescência e C14, apresentando datas entre 2.190 +- 185 A.P. e 11.000 +- 1.000 A.P. (por TL) e 14.200 +1.150 A.P. no nível 10 (por C14; vide Beltrão et al. 1983). Tais datas dividiram a comunidade de arqueólogos do Brasil. Muitos não aceitaram tal antigüidade para o Homem na América do Sul, afinal, na época em que foram divulgadas, as idades do Alice Bôer colocariam o sítio como contemporâneo a Clovis, nos EUA, com uma indústria lítica nada similar. A data mais antiga, obtida por rádiocarbono pode ser questionada devida sua relação indireta entre o carvão datado e o material arqueológico, e pela abundância de evidências de bioturbação na estratigrafia do sítio. As datas obtidas por TL, porém, são 
bastante confiáveis por se relacionarem às próprias peças líticas com alteração térmica, não dependendo de argumentos de ligação e tornando, portanto, irrelevantes as questões de perturbação estratigráfica. “Dado o estado de conhecimentos atuais com relação às idades de alguns sítios pleistocênicos no Brasil, pode-se aceitar sem problemas que Alice Bôer é um sítio cuja primeira ocupação se deu em torno de 11.000 anos A.P., o que o mantém como mais antigo do Estado de São Paulo” (Araújo, 2001b: 135). Cabe uma menção a atuação de Tom O. Miller Jr nessa região. Inicialmente vinculado ao PRONAPA, Miller Jr. aos poucos se distanciou dessa linha teórica e passou a adotar procedimentos considerados hoje de vanguarda para a Arqueologia Brasileira. Com pensamentos convergentes com a literatura norte-americana, aplicando os conhecimentos arqueológicos aos estudos de Paleoambiente, também foi pioneiro na experimentação, somente hoje usada como importante ferramenta para a interpretação do registro arqueológico.

Os estudos arqueológicos se estendem por toda a década de 1980, com destaque para o programa de pesquisas arqueológicas para o médio curso do rio Tietê e vale do Rio Pardo, realizado pelo Instituto de Pré-história da Universidade de São Paulo, sob coordenação de Solange Bezerra Caldarelli e Walter Neves, seguida por Marisa Afonso Coutinho (1987). As pesquisas também se estendem para a região do vale do rio Paranapanema através dos trabalhos de Águeda Vilhena, José Luiz de Morais e Paulo Antonio Dantas de Blasis (1984; 1988; 1989 respectivamente). Na região do médio Tietê e vale do Rio Pardo, em 1983, através da tese de doutorado de Solange Caldarelli, foram encontrados sítios a céu aberto de variados tamanhos e em diversas situações topográficas, nos terrenos aplainados da depressão periférica e zonas limítrofes, exibindo sempre uma indústria lítica onde o sílex é praticamente a matéria-prima exclusiva, fato esse devido à sua abundância naquela área. Contudo, para alguns casos, destaca-se a presença do arenito silicificado. Diferencia-se desse contexto o sítio abrigo Sarandi, cuja escavação revelou uma única camada arqueológica estratigráfica homogênea, que foi datada em 5.540 +- 120 A.P. Ainda nesse ano, José Luiz de Morais realiza seu doutoramento, estudando o sítio Caiuby, em Santa Bárbara do Oeste. Com uma indústria lítica onde predomina o sílex, seu acervo apresenta um alto grau de elaboração, possuindo bifaces, pontas de projétil, raspadores e unifaces, finamente retocadas. As datas para esse sítio, obtidas a partir de uma 
estrutura de combustão associada aos vestígios arqueológicos, em idade calibrada foram de 6.230 a 6.180 A.P.

No vale do Paranapanema, o sítio Almeida, quando escavado, apresentou grande quantidade de vestígios, principalmente detrito de lascamento, onde o arenito silicificado aparece como matéria-prima predominante. Sua tipologia consiste principalmente em lascas retocadas e raspadores diversos, de grandes proporções. Características semelhantes possui o sítio Camargo, situado junto a um afloramento de arenito silicificado. As datas provenientes desses sítios giram em torno de 3.000 A.P. O sítio Brito completa esse conjunto assentamentos pré-históricos, destacando, no entanto, sua data mais recuada de 7.020 +- 70 A.P. (Vilhena, 1984).

Em 1988, o Vale do Ribeira de Iguape, foi alvo de estudo de Paulo Antônio Dantas de Blasis. O pesquisador classifica a região como “área de transição”, valorizando suas características ambientais, de ligação entre litoral e interior, não havendo a barreira da serra do mar. Justamente por essa peculiaridade, a ocupação pré-histórica desse local teria sido marcada pelo contato entre grupos do interior e da costa. Vários sítios líticos foram identificados, revelando "um padrão nucleado de assentamento, com um ou dois sítios de atividades diversificadas articulados a vários outros sítios menores, de atividades limitadas” (De Blasis, 1988: 130). A distribuição dos vestígios e instrumentos líticos aponta para uma tipologia funcional básica entre os sítios, sugerindo sua articulação e integração no interior de cada agrupamento, onde a maior parte das atividades está presente em um sítio central, cercado por outros sítios menores, com diferentes atividades ou menos intensas. O conjunto dessas evidências aponta claramente para a integração dos sítios no agrupamento, formalizando um assentamento conjunto, que poderia ser denominado por aldeia. A partir disso, De Blasis interpreta que esses agrupamentos representam "um assentamento integrado em nível de comunidade” (De Blasis, 1988: 130). Para reforçar sua hipótese, o arqueólogo compara a disposição dos sítios arqueológicos com os assentamentos rurais existentes na atualidade. Apesar de grupos tão distantes no tempo, e de modo de vida distintos, os assentamentos rurais estão dispostos quase que da mesma forma que os pré-históricos. Isso ressalta, segundo o autor, a imposição que faz o meio para os grupos humanos que lá se instalam. Os sítios líticos, por sua vez, estariam associados a caçadores-coletores provenientes do planalto meridional brasileiro e a época de sua 
proveniência, devido à ausência de datações, é incerta. Analisando as características do material lítico, que estaria associada a caçadores-coletores do holoceno, o período de ocupação desses grupos poderia ter se dado em um tempo máximo de 8.000 A.P. e mínimo de 2.000 A.P. Interessante notar para esse conjunto de sítios líticos, associados aos caçadores da região sul do Brasil, é que, diferente do que até então se supunha, os assentamentos do médio Ribeira ocupam uma região densamente florestada e ecologicamente homogênea, e o padrão de sua distribuição espacial sugere, inclusive, a possibilidade de assentamentos permanentes. A causa disso, segundo De Blasis, seria o reflexo de uma migração tardia, relativamente recente, "provocada pela ocupação do planalto por grupos horticultores, que teriam empurrado para as zonas periféricas das grandes bacias hidrográficas (incluindo o médio Ribeira) os pequenos grupos remanescentes de caçadores, possivelmente refratários a mudanças em seu estilo de vida milenar” (De Blasis, 1988: 155).

Com as pesquisas do PRONAPA (1965-1971) soma-se o número dos sítios arqueológicos destinados ao material lítico. Entretanto, esse projeto destinou uma atenção maior aos sítios cerâmicos, não aprofundando assim os conhecimentos acerca dos caçadores-coletores (Caldarelli, 1983; Dias, 2003), e ainda, o modelo "pronapiano”, pautado no modelo Histórico-cultural, onde a análise dos sítios tinha como fim enquadrar suas coleções dentro de tradições, sub-tradições e horizontes (Lanata \& Borrero, 1999) não enfatizava temas como os padrões de assentamento, as relações entre eles e, no caso do material lítico, uma análise voltada ao entendimento da cadeia operatória, que destaca a tecnologia e não a tipologia.

O número de pesquisadores engajados foi insuficiente para que se pudesse obter as informações necessárias que possibilitassem a criação de um panorama da ocupação caçadora-coletora e da implantação dessa classe de sítios no Estado de São Paulo. Destacamos desse contexto o trabalho de Solange Bezerra Caldarelli (1983), que fugindo desse padrão vigente na época, buscou um foco mais interpretativo, direcionando-se por meio de estudos etno-arqueológicos para o auxílio na compreensão dos produtores dos artefatos arqueológicos.

Com o advento da Arqueologia ligada aos estudos de impacto ambiental, o número de sítios arqueológicos identificados no Estado de São Paulo aumenta substancialmente. A 
partir da ação de empresas privadas, vários estudos se iniciam através dos licenciamentos ambientais e têm continuidade, muitas vezes, pelo aproveitamento de trabalhos acadêmicos. Dessa forma, sítios de relevância aparecem. A exemplo, em 1997, em um trabalho realizado pela empresa Documento Antropologia e Arqueologia (2003), no município de Mogi Mirim, foi identificado um importante sítio lítico, denominado Bela Vista I. Sua indústria lítica caracterizou-se pela predominância do sílex como matéria-prima, a presença de pontas de projétil, e diversos instrumentos ativos. A datação de carvões, realizada por C14, forneceu a idade máxima de 9.540 A.P. Dando continuidade aos trabalhos, a empresa Zanettini Arqueologia (2005) identificou nas cercanias mais dois sítios líticos, denominados Bela Vista 2 e Bela Vista 3. Também, no ano de 1997, na cidade de Ouroeste, às margens do Rio Grande, divisa com Minas Gerais, dois pescadores encontraram, por acaso, ossadas humanas, depois de avistarem uma área onde havia caído uma árvore nas margens do rio Grande, próximo da Usina de Água Vermelha, comandada atualmente pela empresa AES Tietê. O material despertou tanta atenção que uma equipe de arqueólogos, comandada por Paulo De Blasis e Erika Robhran-Gonzales da USP foi chamada ao local para fazer os primeiros estudos. Por conta da riqueza do material coletado, construiu-se o Museu Água Vermelha para abrigá-lo. Os materiais em exposição retratam ocupações de quatro civilizações que viveram na região em diferentes épocas, sendo a mais antiga, encontrada no sítio Água Vermelha 3, datada por C14 - as ossadas foram datadas - em mais de 9.000 anos antes do presente (9a SR/IPHAN/SP \& Zanettini, 2010).

\section{I.4) A região Central do Estado de São Paulo: panorama etnográfico e histórico das pesquisas arqueológicas}

Sobre a ocupação humana pretérita dos "Campos de Aracoara", podemos compreende-la melhor, atualmente, por meio de algumas fontes históricas de cronistas e viajantes. Embora para a época pré-contato só tenhamos as fontes materiais como testemunho dos encontros e confrontos étnico-culturais ocorridos na região, as fontes históricas podem fornecer subsídios para o panorama etnográfico da região em tempos remotos, na medida em que admitimos continuidades e descontinuidades no modo de vida indígena no pré e no pós-contato com a sociedade ocidental. 
Até o século XVIII, a região de Araraquara não havia recebido grande atenção de colonos, por ser considerada um "sertão" de pouco valor econômico, servindo somente de passagem para os aventureiros em busca de ouro e riquezas em terras além destes sertões economicamente "inférteis". A região, porém, não se encontrava desabitada. Nas palavras de Marcel Mano: “... O planalto ocidental paulista poderia ter facilmente servido como região de intenso tráfego de elementos culturais, via de escoamento e corredor de influências porque sitiado, a um lado, pelas serras de Piratininga e o litoral atlântico; por outro pela região do Chaco que se forma a oeste da bacia do Paraná; ao norte pelos campos e matas do Brasil central; e ao sul pelos campos férteis do Paraná e os pampas (...) cada uma dessas áreas geográficas ocupada por populações indígenas culturalmente diferentes - Guarani (Mbia e Nhandeva), Tupi, Guaicuru-Mbaia, Aruak, Jê, entre outras..." (Mano, 1998:25).

Esta diversidade étnica é atestada pelo desencontro de informações nas fontes históricas, concernentes à afiliação lingüística dos grupos que foram encontrados na região. Os vestígios arqueológicos encontrados em cidades como São Carlos, Ibaté, Rincão, Rio Claro e Ibitinga, podem apresentar, em conformidade com esses documentos, indícios desta ocupação heterogênea da região, porém, não há, ainda, subsídios para elaborar teses sobre a ocupação da região.

Pelos textos históricos, em linhas gerais, os Campos de Aracoara parecem ter sido palco de ocupação dos Guaianás (Guanhanã, Goianases, Goanhanaz), de língua Jê, porém, não os únicos senhores destas terras. Outras fontes também citam o povo Tupiniquim (língua Tupi), Bororo, Xavante e Caiapó (Jê), Carijó (Guarani), dentre outros.

As informações arqueológicas existentes sobre a área de inserção do presente trabalho referem-se a estudos realizados na região de Rio Claro e na bacia do Rio Corumbataí por professores da antiga FFCL de Rio Claro, na década de 1960; pesquisas realizadas nas grutas e abrigos sob rocha, localizados na frente escarpada das cuestas, pela Sociedade Brasileira de Espeleologia, no início da década de 1980. Levantamento efetuado nas bacias dos rios Jacaré-Pepira e Jacaré-Guaçu para a APA de Corumbataí, no final da década de 1980 e pesquisas pontuais realizadas pelo Museu de Arqueologia e Etnologia da USP nos municípios de Dois Córregos e Brotas e no traçado do Gasoduto Bolívia-Brasil, na 
década de 1990; além de outras pesquisas de Arqueologia de Contrato/Preventiva que vêm se intensificando a partir da última década.

A primeira intervenção ocorrida na região araraquarense se deu somente no início da década de 1970, envolvendo o salvamento arqueológico emergencial em um sítio cerâmico relacionado à Tradição Tupiguarani, localizado na Fazenda Bom Retiro, município de Rincão. Dele foram extraídas duas urnas funerárias com decoração geométrica pintada, uma delas, atualmente, exposta no Museu Histórico e Pedagógico “Voluntários da Pátria”/Araraquara. Segundo informações, o outro artefato integrou o acervo do Museu Paulista-USP. Para este primeiro trabalho, uma equipe do Museu Paulista foi acionada. Os trabalhos foram coordenados pela arqueóloga Luciana Pallestrini que descreveu sucintamente o contexto dos achados: “...à primeira vista o tipo de sítio é, segundo características já conhecidas, correspondente a aldeias pré-históricas situadas quase no ápice da colina, com rio em sua base, apresentando vestígios de restos de choupanas e enterramentos em seu interior” (citada in Polezze, 1972).

A partir de então se observa um hiato temporal de praticamente duas décadas. Em 1998, o arqueólogo Paulo De Blasis apresentou o relatório final do Programa de Salvamento Arqueológico ao longo do traçado Bolívia-Brasil (GASBOL), na porção referente a sua passagem no Estado de São Paulo, indicando ocorrências no trecho Paulínia/Rio Paraná, interessando-nos as menções feitas para as imediações de São Carlos.

No município de Ribeirão Bonito, foi registrado um sítio histórico, constituído por refugo provavelmente associado à unidade habitacional de período relativamente recente (primeira metade do século XX). Em Ibitinga foi localizado o sítio Jacaré, apresentando material cerâmico Tupiguarani (De Blasis 1998:22).

Em 2000 e 2001, outros dois trabalhos de levantamento arqueológico foram realizados na região. O primeiro, sob a responsabilidade de Solange Caldarelli, intitulado Levantamento arqueológico na faixa de domínio da duplicação da Rodovia SP 255: km 2,8 a 50, assinalou a existência de sítio arqueológico no município de Guatapará. O segundo relatório, de autoria de Robrahn-González \& Zanettini, intitulado Programa de levantamento e resgate arqueológico - Fábrica da EMBRAER, conduziu a localização de sítio fora da área do empreendimento, no vale do Rio Jacaré-Guaçú, bastante alterado (município de Gavião Peixoto). Ainda no ano de 2001, por conta da implantação da Usina 
Hidrelétrica Duke 1, no município de Pederneiras, foi resgatado, pela empresa Documento Antropologia e Arqueologia, o sítio lítico Pederneiras I. No "Programa Arqueológico Gasoduto Araraquara/Norte - Trecho Boa Esperança do Sul - Araraquara, Estado de São Paulo”, foram identificados três sítios líticos que foram resgatados em 2003 pela empresa Zanettini Arqueologia. Desses três sítios, dois (o BES II e BES III) são os alvos da pesquisa de mestrado em pauta.

Sobre o município de Jaú temos, em seu museu municipal, algumas coleções com origens da própria cidade, também de Itapuí e da região dos Três Rios, em Dois Córregos. Município este, onde há ainda o Sítio Lítico Três Rios, que originou a dissertação de mestrado de Andrea Lourdes Monteiro Scabello (1997). Tal sítio foi identificado pelo Projeto Oeste Paulista de Arqueologia do Baixo e Médio Vale do rio Tietê, iniciado na década de 1970, que detectou além deste, sítios lito-cerâmicos em Barra Bonita, Arealva e Ibitinga.

Em 2003 foram identificados, através de peritagem arqueológica para implantação de Aterro Industrial, os sítios Bocaína I e II, ambos líticos (9ª SR/IPHAN/SP).

Em 2004, trabalhos de levantamento arqueológico, por conta de duplicação de rodovia, detectaram mais dois sítios líticos na região central do Estado, os sítios Brotas e Bauru. Mais recentemente, em 2005, o outro sítio, também foco da presente pesquisa, foi salvo pelo projeto "Resgate do Sítio Arqueológico Dois Córregos, município de Dois Córregos”, e ainda no mesmo ano, em prospecção arqueológica para Linha de Transmissão $525 \mathrm{Kv}$ Londrina (PR) - Araraquara (SP), foram identificados os Sítios Boraceia I e II, sendo o primeiro cerâmico e o segundo lítico. Todos esses trabalhos foram realizados pela Scientia Consultoria Científica. No mesmo ano, mais uma vez em Gavião Peixoto, foi resgatado pela mesma empresa, por projeto para a CPFL, o sítio lítico homônimo deste município. Também foi encontrado no município de Jaú em 2005 um sítio lítico, pelo projeto "Estudos Arqueológicos na Bacia Hidrográfica do Rio Jaú” com portaria liberada pelo Iphan ${ }^{12}$. No ano de 2007, por sua vez, em prospecções arqueológicas para a ampliação da linha de Transmissão $138 \mathrm{Kv}$, nos trechos Bariri-Barra Bonita, foram identificados dois sítios líticos, um no município de jaú e outro em Itapuí (Scientia, 2008). Complementam-se

\footnotetext{
${ }^{12}$ Portaria ${ }^{\circ} 421$ publicada no diário oficial de 29/12/2005, com apoio institucional do Museu municipal de Jaú.
} 
a esses dados algumas informações de cunho histórico ${ }^{13}$. Por fim, o trabalho de doutoramento de Solange de Oliveira Nunes Schiavetto, finalizado no início de 2007, onde na etapa de levantamento, publicada em forma de artigo na Sociedade de Arqueologia Brasileira, detectou sítios cerâmicos, líticos e lito-cerâmicos, além de indícios esparsos nos municípios de Rincão, Américo Brasiliense, Boa Esperança do Sul, Araraquara e Ribeirão Bonito.

A grande maioria dos sítios arqueológicos registrados na área de estudo refere-se a sítios líticos a céu aberto, ou seja, sítios arqueológicos onde os vestígios consistem em artefatos de pedra confeccionados pela técnica do lascamento. Apesar de sabermos que sítios líticos não devem ser necessariamente associados a populações caçadoras-coletoras, o modo como se encontram dispersos todos esses vestígios e antigos assentamentos denunciam essa relação. Ou seja, pequenos grupos em constante movimento pela região.

\begin{tabular}{|c|c|c|c|}
\hline ACHADO & $\begin{array}{l}\text { QUADRO } \\
\text { ARQUEOLÓGICOS NA }\end{array}$ & $\begin{array}{l}\text { RESUMO } \\
\text { REGIÃO CENTRAL DO }\end{array}$ & ESTADO \\
\hline MUNICÍPIO & $\begin{array}{l}\text { TIPO DE SÍTIO E/OU } \\
\text { OCORRÊNCIA }\end{array}$ & DRENAGEM & BACIA \\
\hline Araraquara & $\begin{array}{l}2 \text { sítios líticos - por } \\
\text { Solange } \\
\text { (2007) e } 1 \text { Lito-cerâmico } \\
\text { - por Documento } \\
\text { Arqueologia S/C Ltda } \\
(2001)\end{array}$ & $\begin{array}{l}\text { Córrego dos Andes e } \\
\text { Riberião das Cruzes }\end{array}$ & Jacaré-Guaçu \\
\hline $\begin{array}{l}\text { Boa Esperança do } \\
\text { Sul }\end{array}$ & $\begin{array}{l}3 \text { sítios líticos (lascado) e } \\
2 \quad \text { ocorrências líticas } \\
\text { (lascado) }\end{array}$ & $\begin{array}{l}\text { Córregos Mandaguari, } \\
\text { Ribeirão do Ouro e } \\
\text { Rancho Grande }\end{array}$ & Jacaré-Guaçu \\
\hline
\end{tabular}

\footnotetext{
${ }^{13}$ Temos o relato de memorialista que em sua obra "Jahu em 1900" ao se referir sobre as monções que passavam por Jaú (na época Potunduva), no período em que estas terminaram, "seçou por consequencia avenda e exportação dos generos coloniaes de potunduva, e porisso dezampararam os colonos aquéla paragem fertil, porem emfestada de selvagens" (TEIXEIRA, 1900). Ainda encontramos a informação de que na década de 1840, "com a notícia espalhada em Brotas da Fertilidade do vale do rio Jaú e a retirada dos índios Coroados para a outra margem do rio Tietê, organizou-se uma caravana de aventureiros com o fim de abrir uma estrada e tomar posse das terras devolutas" (IBGE, 1966).
} 


\begin{tabular}{|c|c|c|c|}
\hline & 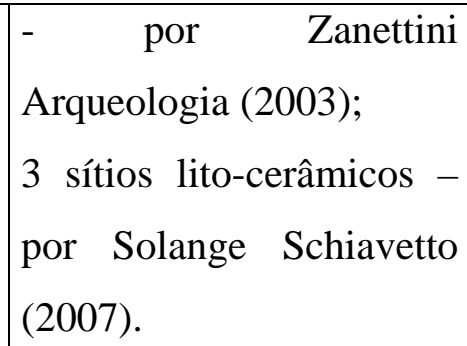 & & \\
\hline Guarapiranga & $\begin{array}{l}1 \text { ocorrência r lítica } \\
\text { (polido) - por Solange } \\
\text { Schiavetto (2005) }\end{array}$ & & Jacaré-Guaçu \\
\hline Ribeirão Bonito & $\begin{array}{l}1 \text { sítio histórico (séc.XIX) } \\
\text { - por MAE/USP - } \\
\text { GASBOL(1998); } \\
1 \text { sítio lito-cerâmico - por } \\
\text { Solanger } \\
\text { (2007). }\end{array}$ & Córrego São João & Jacaré-Guaçu \\
\hline Gavião Peixoto & $\begin{array}{l}2 \text { sítios líticos - por } \\
\text { Scientia (2005); } \\
1 \text { sítio histórico - por } \\
\text { Documento Arqueologia } \\
\text { S/C Ltada. (2001) }\end{array}$ & & Jacaré-Guaçu \\
\hline Itirapina & $\begin{array}{l}3 \text { sítios líticos e } 1 \\
\text { cerâmico } \\
\text { - por Scientia } \\
(2008)\end{array}$ & Rio Itaqueri e Passa Cinco & $\begin{array}{l}\text { Jacaré-Guaçu e } \\
\text { Corumbataí }\end{array}$ \\
\hline Charqueada & $\begin{array}{l}6 \text { sítios líticos }- \text { por } \\
\text { Scientia (2008) }\end{array}$ & $\begin{array}{l}\text { ribeirão Vermelho (Rio } \\
\text { Passa Cinco) }\end{array}$ & Corumbataí \\
\hline Ibaté & $\begin{array}{l}3 \text { sítios históricos - por } \\
\text { MAE/USP - GASBOL } \\
(1998) .\end{array}$ & & Jacaré-Pepira \\
\hline Brotas & $\begin{array}{l}1 \text { sítio } \quad \text { lítico }- \text { por } \\
\text { Scientia } \quad \text { Consultoria } \\
\text { Científica } \\
\text { (2004 e } 2008) \\
\text { e } 6 \text { cerâmicos }\end{array}$ & Rio Jacaré-Pepira & Jacaré-Pepira \\
\hline
\end{tabular}




\begin{tabular}{|c|c|c|c|}
\hline Rincão & $\begin{array}{lr}3 \text { sítios cerâmicos - por } \\
\text { Solagen } & \text { Schiavetto } \\
\text { (2007); } 1 \text { sítio lítico - por } \\
\text { Zanettini } \quad \text { Arqueologia, } \\
\text { (2006). }\end{array}$ & Rio Mogi-Guaçu & Mogi-Guaçu \\
\hline Santa Lúcia & $\begin{array}{l}1 \text { sítio Lítico lascado e } \\
\text { polido - por Rodrigues e } \\
\text { Schiavetto (2007). }\end{array}$ & Ribeirão das Anhumas & Mogi-Guaçu \\
\hline Bauru & $\begin{array}{l}\text { sítio lítico }- \text { por } \\
\text { Scientia (2008) }\end{array}$ & Córrego Pau D’Alho & Batalha \\
\hline Bocaína & $\begin{array}{l}2 \text { sítios líticos }- \text { por } \\
\text { Scientia (2003) }\end{array}$ & Córrego do Peão & Tietê \\
\hline Boracéia & $\begin{array}{l}1 \text { sítio lítico, } 1 \text { ocorrência } \\
\text { lítica e } 1 \text { sítio cerâmico - } \\
\text { por Scientia Consultoria } \\
\text { Científica (2004 e } \\
2005 g) \text {. }\end{array}$ & $\begin{array}{l}\text { Córregos Monte Alegre e } \\
\text { Água das Pratas. }\end{array}$ & Tietê \\
\hline Botucatu & $\begin{array}{l}6 \text { sítios Líticos, } \\
\text { cerâmicos e } 3 \text { históricos - } \\
\text { por Zanettini Arqueologia } \\
\text { (2007 e 2009). }\end{array}$ & $\begin{array}{lll}\text { Córrego Lavapés } & \text { e } \\
\text { Caiuazinho } & & \\
\end{array}$ & Tietê \\
\hline Arealva & $\begin{array}{l}4 \text { sítios Líto-cerâmicos - } \\
\text { por Silvia Maranca } \\
\text { (1994). }\end{array}$ & & Tietê \\
\hline Barra Bonita & $\begin{array}{l}1 \text { sítio Lito-cerâmico - } \\
\text { por Silvia Maranca } \\
\text { (1994). }\end{array}$ & & Tietê \\
\hline Pederneiras & $\begin{array}{l}1 \text { sítio Lítico }- \text { por } \\
\text { Documento Antropologia } \\
\text { e Arqueologia Ltda } \\
\text { (2001). }\end{array}$ & Rio Lençóis & Tietê \\
\hline
\end{tabular}




\begin{tabular}{|c|c|c|c|}
\hline Dois Córregos & $\begin{array}{l}2 \text { sítios líticos e } 2 \text { lito- } \\
\text { cerâmico - por Silvia } \\
\text { Maranca (1994) Andrea } \\
\text { Lourdes Scabello (1997) } \\
\text { e Scientia Consultoria } \\
\text { Científica (2005). }\end{array}$ & Rio Turvo e Tietê & $\begin{array}{l}\text { Tietê } \\
\text { Piracicaba }\end{array}$ \\
\hline Jaú & $\begin{array}{lr}2 \text { sítios líticos } & \text { e } \\
\text { ocorrências } & \text { líticas } \\
\text { (machados polidos) } & - \text { por } \\
\text { Scientia } & \text { Consultoria } \\
\text { Científica (2008) e Fabio } \\
\text { Grossi dos Santos (2005) }\end{array}$ & $\begin{array}{l}\text { Córrego Águas do Ferraz, } \\
\text { Córrego dos Navarros e } \\
\text { Ribeirão Pouso Alegre }\end{array}$ & Jaú \\
\hline Itapuí & $\begin{array}{l}1 \text { sítio lítico e ocorrências } \\
\text { líticas (lascas em arenito } \\
\text { e sílex) - por Scientia } \\
\text { (2008) }\end{array}$ & Córrego do Campinho & Jaú \\
\hline
\end{tabular}

Tabela 01: Achados Arqueológicos na Região Central do Estado de São Paulo

\section{CAPÍTULO II - BASES TEÓRICAS E MÉTODOS DE PESQUISA}

O principal objetivo deste trabalho é o estudo da implantação dos sítios líticos no interior paulista, mais precisamente na região central, banhada pela Bacia Hidrográfica do Rio Tietê em seu médio/baixo curso. Através da análise de três sítios líticos, dois na região de Araraquara e um na região de Jaú, realizamos estudos intra e inter-sítios, além de comparar os resultados com trabalhos já realizados nas áreas adjacentes e também com a literatura específica. Com ênfase na abordagem regional, buscamos trabalhar questões como intensidade de material arqueológico, estratigrafia, dimensões dos sítios, a distância entre eles, as formas de implantação na paisagem, identificar as áreas de atividades restritas e a tecnologia da indústria lítica. A partir desses resultados, propusemos hipóteses sobre 
possíveis relações de contato entre os sítios, interação de grupos distintos ou então complexos do mesmo horizonte cultural, percebendo assim, a mobilidade no território.

Os sítios objetos da pesquisa são o Boa Esperança II e Boa Esperança III, no município de Boa Esperança do Sul e o sítio Dois Córregos, no município homônimo. Os três sítios foram alvo de resgate arqueológico por conta de trabalho de licenciamento ambiental, em 2003 e 2005, respectivamente (Zanettini, 2003; Scientia, 2005).

Os resultados práticos obtidos, além de complementar as informações já existentes, fornecem material para a elaboração de um quadro da ocupação regional destes grupos e estimular novas discussões e trabalhos sobre o material lítico no interior paulista.

\section{II.1) Detalhamento da pesquisa e colocação do problema}

\section{II.1.1.) A relação HOMEM \& AMBIENTE num aspecto regional}

No período pré-colonial, as condições ambientais propiciavam aos seres humanos uma integração e interação com o ecossistema em que se encontravam. Eles dependiam do ambiente para seus deslocamentos, sua alimentação e obtenção de matéria-prima para a fabricação de instrumentos necessários à sua sobrevivência. Com isso adaptavam-se a situações locais diversas.

Alguns elementos foram fundamentais na escolha de locais para a instalação de habitações dos grupos caçadores-coletores: a proximidade de rios para pesca, para consumo de água e navegação; terras férteis quando se tratava de populações que desenvolviam algum tipo de plantio; mata para coleta e caça.

A relação com o meio ambiente, no entanto, não se esgota com a apropriação dos recursos ecológicos para sua sobrevivência. A produção material que se realiza neste espaço incorpora várias dimensões que embasam as condições de vida de uma determinada população.

No intuito de contribuir para o conhecimento sobre a ocupação do interior do Estado de São Paulo, principalmente na região centro-oeste do Estado, numa área influenciada pelas bacias hidrográficas dos rios Tietê e Jacaré-Guaçu, tentamos entender a relação 
existente entre o Homem e o ambiente natural num aspecto regional, partindo do âmbito local, para depois podermos fazer comparações com contextos geográficos mais amplos.

Com base na suposição de que "os sítios arqueológicos não constituem entidades isoladas, mas articulam-se em sistemas, os quais só podem ser conhecidos se não se desprezar nenhum de seus componentes” (Caldarelli, 1983:11) , estabelecemos níveis de análise distintos para investigar similaridades e diferenças entre conjuntos líticos oriundos de contextos distintos, estejam esses contextos inseridos em micro ou macro-escalas. Isso quer dizer que podemos comparar esses aspectos no mesmo sítio, entre sítios de uma mesma região e entre conjuntos de sítios de diferentes regiões. Assim, tornou-se possível averiguar de forma mais detalhada o que é, e o que não é compartilhado e, dessa maneira, articulamos ambas as escalas - micro e macro, escolhas e estratégias, gestos e paisagem (Bueno, 2007b : 91).

A fim de compreender a dinâmica social em um determinado espaço, a questão da variabilidade tecnológica é eminentemente inclusiva. Enfatizando a importância das escolhas, associando-as às performances desempenhadas por cada artefato em situações específicas, mas interligadas e associadas às demais esferas da sociedade, é que procuramos articular gestos e paisagens, o que significa articular abordagens francesas e norteamericanas $^{14}$ no estudo da tecnologia lítica, ou seja, como já mencionamos, articular as diferentes escalas - micro e macro, intra-sítio e regional (Bueno, 2007b). É nesse sentido que ter o conhecimento de um número considerável de sítios arqueológicos de uma determinada área faz-se imprescindível, pois esse fator torna-se positivo no sentido de proporcionar uma visão mais ampla do contexto arqueológico local, não se restringindo apenas a estudos de caso, presos a sítios únicos, o que prejudica uma visão regional (Lanata \& Borrero, 1999).

Para entendermos como se deu determinada ocupação em um local, assim como eram os produtores do registro arqueológico que estudamos, é preciso partir da idéia de que “compreender a tecnologia lítica como integrada aos sistemas tecnológicos de uma dada

\footnotetext{
${ }^{14}$ Os métodos franceses a serem utilizados tem sua maior representação em A. Leroi-Gourhan (1983). o método "etnográfico", por meio da técnica de decapagens em níveis de solos naturais, com manutenção das evidências in situ até o registro fotográfico e cartográfico. Essa técnica permite uma visão do contexto tridimensional das estruturas arqueológicas, possibilitando análises acuradas das relações intra-sítio. Já os métodos norte-americanos buscam padrões regularizados de comportamentos (leis universais). Para isso, criam modelos a partir de estudos com escalas mais amplas que as da análise intra-sítio, recorrendo assim a análise inter sítios. O maior representante dessa vertente é Lewis Binford (1980).
} 
sociedade permite situar a variabilidade observada como construção social resultante de escolhas culturalmente determinadas” (Dias, 2007 : 37). Sendo assim, “a variabilidade local das indústrias líticas, apontaria para estratégias de demarcação, através da cultura material, dos territórios locais” (Dias, 2007 : 61).

Seguindo essas idéias, pretendemos conhecer a forma de ocupação da paisagem em um determinado período. "Partindo das matérias-primas, passando pelos gestos associados a sua exploração, pela distribuição dos vestígios produzidos e pela articulação entre esses aspectos e a distribuição dos sítios aos quais estão associados procuramos identificar as escolhas efetuadas, os designs produzidos e as performances requeridas a fim de entender a organização dessas atividades no espaço e assim caracterizar a tecnologia lítica nessa ocupação associando-as a outros aspectos como, mobilidade, território e paisagem” (Bueno, 2007b: 91).

As relações homem - meio-ambiente e a compreensão de como se desenvolveram no decorrer do tempo, manifestando-se em diferentes momentos através de uma certa organização espacial só podem ser apreendidas através de abordagens que cruzem campos afins tanto das Ciências Humanas quanto das Geociências. Nesse sentido é que Butzer em 1973 define a “Geoarqueologia” como sendo o estudo e interpretação de sedimentos e paisagens físicas, essencial para uma abordagem ecológica da Pré-História.

Butzer ainda cita a “Arqueologia Espacial”, que dentro desse olhar interdisciplinar, também vem contribuir muito com essa pesquisa, especialmente quando é dada ênfase ao macro nível, onde a perspectiva geográfica é muito utilizada (Afonso, 1987: 4).

\section{II.1.2) Contribuição dos estudos bibliográficos para a compreensão da região}

Visando contribuir para o estudo dos espaços que foram ocupados por populações pretéritas na região central do Estado de São Paulo, buscamos promover uma discussão sobre as teorias que tratam das diferentes formas de ocupação do espaço, das dispersões e migrações desses grupos.

Para esse fim, fizemos uso de conclusões estabelecidas por alguns autores clássicos nacionais ou estrangeiros como Jacques Tixier, Andre Leroi-Gohran, Lewis Binford, 
Joseph Emperaire/Anette Laming, André Prous, Tom O. Miller Jr, Águeda Vilhena, José Luiz de Morais, Solange B. Caldarelli dentre outros. Como também de autores que atualmente pesquisam sítios líticos no Brasil e, sobretudo no interior paulista, como, Paulo D. De Blasis, Adriana Dias, Marisa C. Afonso, Astolfo G. M. Araújo, Emílio Fogaça, Lucas Bueno, e outros; pois estes tratam ou já trataram de questões como sistemas de assentamento e a mobilidade dos grupos caçadores-coletores. Além destes, por meio de um levantamento bibliográfico de outros cronistas, etnólogos, arqueólogos e historiadores que porventura estudaram esses temas, procuramos conhecer suas construções hipotéticas promovendo, assim, uma análise e interpretação dessas questões.

\section{II.1.3) Os sistemas de assentamento na região central do Estado de São Paulo}

Definir os sistemas de assentamento dessa região também foi um dos objetivos principais desse trabalho, visto que, como observado acima, não trabalhamos com um sítio arqueológico somente.

Mas antes disso, é importante deixar clara a escolha pelo uso do termo "sistemas de assentamento" e não "padrões de assentamento”. De acordo com uma revisão crítica nesses conceitos, os estudos de padrões de assentamento observariam, basicamente, a relação geográfica e fisiográfica de um grupo contemporâneo de sítios de uma única cultura. Já o conceito de sistemas de assentamento permitiria compreender a relação funcional entre um grupo contemporâneo de sítios, associados ao padrão de assentamento de uma mesma cultura. Essa estratégia de pesquisa ${ }^{15}$, estrutura-se a partir de uma noção sistêmica de cultura, segundo a qual pessoas, coisas e lugares são os componentes de um campo que consiste dos subsistemas ambiental e sócio-cultural. Assim, uma das características básicas de um sistema cultural seria a integração de indivíduos e unidades sociais, desempenhando distintas tarefas em diferentes locais. Por isso seguimos a orientação de sistemas de assentamento, valendo-nos do pressuposto de que os sítios distribuem-se intencionalmente no espaço, em função tanto do contexto social, quanto do contexto ambiental, não podendo ser explicados como entidades isoladas (Dias, 2003).

\footnotetext{
${ }^{15}$ Adotada pela Nova Arqueologia ou Arqueologia Processual.
} 
Por isso reforçamos a escolha de três sítios para serem analisados separadamente e comparados entre si, articulando esses dados com uma análise bibliográfica das pesquisas de sítios líticos no Estado de São Paulo.

E assim, para dar fim a essa proposta, foram alvos de nossa atenção três condicionantes primordiais à instalação humana em um determinado território:

a) as condições ambientais;

b) a proximidade de fontes de matéria-prima para fabricação de utensílios;

c) a produtividade primária do local (fonte de alimentos).

\section{II.1.4) A Mobilidade}

Após a definição dos sistemas de assentamento, estruturamos, a partir das informações compiladas, uma interpretação a respeito da mobilidade desses povos. De acordo com Binford, existem dois tipos de mobilidade entre os grupos caçadores-coletores: a mobilidade residencial, caracterizada pelo deslocamento de bandos inteiros ou grupos locais de um acampamento para outro; e a mobilidade logística, caracterizada por deslocamentos de indivíduos ou pequenos grupos com tarefas específicas, que após terem cumprido seu dever regressam ao acampamento residencial. O primeiro tipo de mobilidade estaria ligado a grupos classificados como forrageiros, que possuem como características distintas o não armazenamento de comida, fazendo com que tenham que sair em campanhas de coleta diariamente, regressando ao anoitecer à suas bases residenciais. Outra característica ímpar é o fato de poder haver entre eles uma grande variabilidade no tamanho do grupo, assim como o número de deslocamentos residenciais que são feitos durante um ciclo anual. O segundo tipo de mobilidade estaria ligado a grupos coletores, caracterizados pelo estoque de comida por pelo menos parte do ano e também por deslocamentos logísticos organizados para a procura de alimento (Binford, 1980). Outra consideração de propriedade acerca da mobilidade dos caçadores-coletores é feita por Sahlins ao perceber o movimento desses grupos como primordial na manutenção de uma produção vantajosa na sua economia (Sahlins,[1972] 1977). 
Tendo essas idéias como norteadoras e com o levantamento das tipologias dos sítios, suas funcionalidades e demarcações no território, além de analogias com dados etnográficos, formulamos hipóteses partindo dos seguintes pontos:

a) busca por matéria-prima para fabricação de utensílios - sabemos que esse fator é fundamental para a vida cotidiana das populações caçadoras-coletoras, pois é através de seus utensílios (muitas vezes com base em rocha, e nesse caso específico, é o único material que se conservou e chegou até nós) que praticam atividades essenciais para sua sobrevivência, como a caça e fabricação de outras ferramentas. Para facilitar sua obtenção, o homem sempre procurou se estabelecer em locais próximos a essas fontes, sejam afloramentos rochosos ou cascalheiras. Quando isso não era possível, ele tinha que se deslocar para poder obtê-la. Assim como nos mostra Gould (1971) ao salientar que a procura pela matéria-prima pode ser feita dentro de uma média de 40 a 45 quilômetros de distância. No Brasil temos o exemplo do sítio Capivara 5, no Estado do Tocantins, onde a matéria-prima usada na confecção dos utensílios foi buscada a 50 quilômetros de distância do lugar do assentamento (Bueno, 2007). Também no Sítio Boqueirão da Pedra Furada a matéria-prima para o lascamento era buscada à distância. “Uma das fontes do sílex para os povos da Serra Talhada desse sítio encontra-se no Serrote do Sansão, afloramento calcário situado a cerca de $2 \mathrm{Km}$ do mesmo, mas outros tipos de sílex teriam sido coletados até à distância de 50 Km” (Guidon, 1992: 43).

b) relações entre demais grupos (casamentos, confiança e cooperação) - também sabemos que as relações sociais propiciam mobilidade. De acordo com Tim Ingold (2001) os bandos, para garantir a sobrevivência de seus membros procuram casar suas mulheres com homens de outros grupos os mais distantes possíveis, isso para que em épocas onde o lugar de assentamento não mais os pudesse prover, esses teriam destino garantido para se mudar. Há ainda a questão do prestígio dos líderes, que quando não satisfizessem algum membro do grupo, este poderia livremente partir e procurar outro. Esse dado pode nos auxiliar na compreensão de distribuição de sítios, pois devemos entender ainda o aproveitamento dos espaços ocupados por essas populações. De acordo com Tixier, Marmier e Trecolle (1976), seus estudos sobre um sítio pré-histórico em Quargla, Argélia, mostraram que uma área 
aproximada de 2 hectares, com vestígios distribuindo-se em locais distintos, distantes entre si de $60 \mathrm{~m}$ a $220 \mathrm{~m}$ estavam ligados na verdade, a uma mesma ocupação com áreas específicas bem delimitadas e contemporâneas entre si (Caldarelli, 1983);

c) busca por alimentos - a alimentação é o fator mais importante, pois é este que garante primordialmente a sobrevivência do homem. Vivendo basicamente da caça e coleta, esses homens eram sujeitos a procurar lugares que lhes pudesse fornecer quantia suficiente de alimentos. Assim, quando o suprimento do ambiente acabava, eles eram obrigados a se deslocar em busca de novos lugares, e mesmo que não mudassem definitivamente de morada, teriam que ir cada vez mais longe atrás de fonte animal ou vegetal. É o que nos mostra Kim Hill e A. Magdalena Hurtado (2001) no caso dos grupos Aché do Paraguai. Suas observações dessa sociedade mostraram que alguns membros poderiam se deslocar uma distância de até 100 quilômetros em busca de comida, ficando períodos que podiam ultrapassar 2 meses fora de casa;

d) variáveis ambientais - o ambiente tem forte impacto sobre a mobilidade dos grupos caçadores-coletores, pois estes estão intimamente ligados a ele. Seus alimentos provem dele, assim como sua moradia. Dessa forma, não só a questão já citada acima, dos alimentos, mas também climáticas, podem forçar a mobilidade. É o caso de estações de frio intenso ou mudanças drásticas no meio que os cerca. Assim nos mostra o exemplo ilustrado por Robert Kelly sobre os Shoshone dos Estados Unidos, que passam o inverno em aldeias nas florestas em montanhas, na primavera descem para os vales e no fim do verão vão para perto de um rio atrás das trutas; voltando às montanhas no começo do outono (1995). Outro fator ambiental bastante importante são as fontes hídricas, pois a "água corrente é a maior força no desenvolvimento da paisagem e na criação do contexto do habitat das ocupações dos homens pré-históricos” (Rapp \& Hill ,1998:59). Assim, o homem sempre acompanhou os rios em seus deslocamentos, pois além de ser um bom marco geográfico e “caminho natural” trata-se também de fonte de alimentação. Por isso, "muitos autores tem afirmado que a maioria dos vales de rios, terraços, (...) e 
largas junções tributárias foram locais altamente atrativos para a atividade paleolítica” (Brown, 1997:150).

Devido à limitação material dos sítios de Boa Esperança do Sul e Dois Córregos, nem todos os itens aqui destacados puderam ser identificados através do registro arqueológico. Através da análise do material lítico e do contexto ambiental, podemos perceber as relações de busca por matéria-prima para fabricação de utensílios e conseqüentemente alimentos (pois a primeira também se dá em função da segunda). Também podemos perceber as variáveis ambientais. Contudo, as relações sociais mencionadas não são possíveis de se apreender. Mas esse item deve ser considerado na medida em que sabemos que esses fatores influenciam na mobilidade e podem nos auxiliar dando subsídios para compreender questões que às vezes só os dados colhidos em campo não são capazes de esclarecer.

\section{II.2) Etapas de campo}

Os sítios Boa Esperança II e III foram resgatados, pela Zanettini Arqueologia, por conta do Programa Gasoduto Araraquara Norte realizado em 2003 e foram identificados durante a fase de prospecção, juntamente com o BES I (que não foi inserido no presente estudo). Para atender os questionamentos levantados por essa pesquisa de mestrado, foi feita mais uma etapa de campo em Fevereiro de 2010 em ambos os sítios. Na primeira etapa de campo, a de 2003, foram realizadas prospecções de campo envolvendo a cobertura integral da área destinada ao empreendimento, bem como de sua zona de influência direta, consorciando-se a observação direta de áreas degradadas através de prospecções extensivas do tipo varredura com o exame detalhado de todos os pontos favoráveis à análise, e intervenções de sub-superfície (prospecções intensivas com intervalos regulares), através de showel tests, sondagens e tradagens.

De um modo geral, os procedimentos metodológicos adotados nos sítios de Boa Esperança do Sul foram os seguintes:

1. Implantação de malha de referência ortogonal e/ou quadriculada para os estudos. 
Para o início dos trabalhos foi realizada a limpeza em superfície do terreno, a medida do possível, com a retirada da vegetação rasteira ou de pequenas faixas da lavoura de cana. Isto feito, a equipe procedia à implantação da malha de referência, abrangendo, inclusive, uma área superior a inicialmente definida de ocorrência de vestígios durante a etapa de diagnóstico. Todavia, com o objetivo de captar possíveis variações na distribuição do material em profundidade, foram realizadas averiguações para além da zona delimitada.

Mediante o estabelecimento de malhas de quadriculamento, efetuou-se a contagem do material arqueológico existente na superfície de cada quadra/setor definido com posterior coleta sistemática. Os materiais foram ensacados separadamente, contendo referência de seu local de origem, de modo a permitir em laboratório se verificar a existência de áreas de maior e de menor concentração de material no sítio.

2. Abertura de sondagens na área dos sítios, com o objetivo de aferir sua extensão e profundidade, buscando-se definir porções melhor conservadas para escavação de detalhe; As sondagens abertas variaram em tamanho e profundidade alcançando até 1,80/2m, sobretudo, no sitio Boa Esperança II, buscando atingir os níveis naturais e arqueologicamente estéreis, variáveis de acordo com o compartimento da paisagem onde estavam inseridos.

A retirada do solo nas sondagens foi feita em camadas artificiais de $10 \mathrm{~cm}$, sendo que todo o sedimento foi submetido a peneiragem (peneira de malha fina), garantindo a coleta até de micro vestígios de lascamento.

Com o objetivo de produzir uma caracterização detalhada desta indústria, tornou-se importante obter uma boa amostragem de peças, de modo a captar as variações de instrumentos lascados produzidos e/ou utilizados pelos grupos indígenas que ali estiveram. Em todas as sondagens com presença de material foram realizados desenhos dos perfis estratigráficos observados.

Como complementação, no caso do Sítio Boa Esperança II, foi realizada, ainda, coleta de vestígios peça a peça em área dotada de potencial, o que permite em laboratório a reconstituição de cadeias operatórias, desde a seleção de matéria-prima e subprodutos derivados do lascamento, desde lascas intermediárias até subprodutos mínimos de debitagem. Esta área sofreu o rebaixamento do terreno através de técnicas arqueológicas de 
decapagem, com uso de instrumentos de precisão como pincéis e espátulas de bambu. Cada peça lítica evidenciada foi demarcada, com o objetivo de facilitar a leitura de um possível padrão de distribuição dos vestígios.

3. Prospecções extensivas na Área de Influência do empreendimento.

Depois de identificados os dois primeiros sítios, foram intensificadas as prospecções na faixa de $1 \mathrm{Km}$ de cada lado do gasoduto, com ênfase no entorno dos assentamentos detectados, conduzindo a confirmação de mais um sítio, o BES III e mais duas ocorrências.

No caso específico do sítio BES II, a partir da área nuclear do sítio, definida à época do diagnóstico, efetuou-se nova varredura em superfície objetivando refinar a delimitação originalmente estabelecida. O ponto central, onde se verificou a maior concentração de vestígios foi definido como Datum para a implantação da malha de referência, a partir do qual irradiou-se a malha de referência, estendo-se no sentido norte-sul por aproximadamente 285 metros, e no sentido L-O, por cerca de 105 metros lineares, totalizando uma área de $30 \mathrm{mil} \mathrm{m}^{2}$, substancialmente em maior bem relação àquela definida originalmente em $10 \mathrm{mil} \mathrm{m}^{2}$.

Observou-se durante o resgate que o sítio prolongava-se apenas em seu nível mais profundo não ultrapassando mais a área acima mencionada.

O quadro a seguir sumariza o conjunto de intervenções e evidências observadas no sítio Boa Esperança II na etapa de resgate em 2003:

Tabela 02: Intervenções arqueológicas no sítio BES II

Pontos delimitados na malha: 123

Sondagens abertas em quadrícula (1 m x 1 m): 17

Sondagens com presença de material arqueológico: 17

Profundidade das Sondagens: variável entre $0,80 \mathrm{~m}$ e $1,90 \mathrm{~m}$

Poços teste 0,50 m x 0,50 m com profundidade de $1,50 \mathrm{~m}$ : 38, sendo que dois apresentaram material

Implantação de malha de quadriculamento para coleta controlada de superfície: área total: $425 \mathrm{~m}^{2}$ (soma das áreas 1 e 2)

Subquadriculamento no interior da Área 2 para coleta peça a peça: $4 \mathrm{~m}^{2}$

Perfis estratigráficos obtidos: 5 
Para o sítio BES III procedeu-se a realização de limpeza de uma área previamente selecionada, equivalente a $9 \mathrm{~m}^{2}$ para a realização de coleta sistemática dos vestígios presentes em superfície e a abertura de uma sondagem de $1 \mathrm{X} 1 \mathrm{~m}$ e 0,6m de profundidade, atingindo-se o embasamento rochoso e comprovando a presença de material arqueológico até o nível 4 (até 0,4m) (Zanettini, 2003).

A segunda intervenção, ocorrida no início de 2010, objetivou a melhor compreensão da geologia local, bem como os processos pós-deposicionais, dessa forma, a estratigrafia dos sítios e a coleta de amostra para datação por LOE (luminescência oticamente estimulada). Para o sítio BES II, foi identificada a área onde, na primeira intervenção, destacou-se maior concentração e profundidade de material arqueológico. Foram eleitos dois pontos onde se destacaram as maiores profundidades com material registradas em 2003, entre 1,4 e 1,5 m. Feito isso, foram abertas duas unidades de escavação em suas proximidades - a localização exata dos pontos, através das coordenadas em UTM foi prejudicada devido à plantação de cana-de-açúcar que se encontrava alta. A média de distância entre os pontos originais foi de quinze metros. As unidades de escavação foram realizadas no limite do terraço aluvial ${ }^{16}$, onde, por conseqüência dessa localização, há um declive em relação à primeira área de intervenção. Os maiores esforços se concentram na unidade 01, devido à intensidade de material. Suas dimensões foram de 2 x $2 \mathrm{~m}$, sendo divididas em quatro quadrantes de 1 x $1 \mathrm{~m}$ : Nordeste, Sudeste, Sudoeste e Noroeste. A profundidade alcançada foi de 1,13 m, sendo que, por estar muito próximo ao Rio JacaréGuaçu, o solo começou a minar água, impedindo assim, a continuidade da escavação. Também era época de chuvas, fato que colaborou para a maior umidade. Foram coletadas dessa unidade, 476 peças arqueológicas, sendo que a maior parte delas se concentrou entre os níveis 5 e 7 (40 e 70 centímetros). A coleta para datação por LOE foi feita entre os níveis artificiais 6 e 7 por ser o nível de maior concentração de material arqueológico.

Descrição da Unidade de Escavação 01 (2 x 2 m) - Fev/2010

\begin{tabular}{|c|c|c|c|c|c|}
\hline NÍVEL & $\begin{array}{c}\text { PROFUNDIDADE } \\
(\mathrm{cm})\end{array}$ & \multicolumn{3}{|c|}{ MATERIAL POR QUADRANTES (1 X $1 \mathrm{~m})$} \\
\cline { 3 - 5 } & NORDESTE & SUDESTE & SUDOESTE & NOROESTE \\
\hline
\end{tabular}

${ }^{16}$ A classificação como terraço aluvial se permitiu devido a abertura de corte estratigráfico, onde pode se verificar a gleissificação do solo, que lhe confere tal característica. 


\begin{tabular}{|c|c|c|c|c|c|}
\hline 0 & Superfície & 0 & 0 & 0 & 0 \\
\hline 01 & $0-10$ & 0 & 0 & 0 & 0 \\
\hline 02 & $10-20$ & 0 & 0 & 0 & 0 \\
\hline 03 & $20-30$ & 0 & 0 & 0 & 3 peças \\
\hline 04 & $30-40$ & 0 & 0 & 0 & 2 peças \\
\hline 05 & $40-50$ & 1 peça & 0 & 0 & 202 peças \\
\hline 06 & $50-60$ & 2 peças & 0 & 5 peças & 226 peças \\
\hline 07 & $60-70$ & 0 & 0 & 0 & 26 peças \\
\hline 08 & $70-80$ & 0 & 0 & 0 & 9 peças \\
\hline 09 & $80-90$ & 0 & 0 & 0 & 0 \\
\hline 10 & $90-100$ & 0 & 0 & 0 & 0 \\
\hline 11 & $100-110$ & 0 & 0 & 0 & 0 \\
\hline 12 & $110-120$ & 0 & 0 & 0 & 0 \\
\hline
\end{tabular}

Tabela 03: Unidade de Escavação 01 - BES II / Fev 2010

A unidade de escavação 02 foi feita em medidas 1 x $1 \mathrm{~m}$. A presença de material arqueológico foi bem menor, sendo que só foram coletadas 26 peças, concentradas entre os níveis 2 e 3 (10 e 30 centímetros). Sua profundidade alcançou 80 centímetros, tendo sua continuação impossibilitada, assim como no caso da UE 01, também pela infiltração de água. Dessa forma, registrou-se um total de 502 peças coletadas no sítio BES II nessa segunda intervenção arqueológica em Fevereiro de 2010.

Descrição da Unidade de Escavação 02 (1 x 1 m)

\begin{tabular}{|c|c|c|}
\hline NÍVEL & $\begin{array}{c}\text { PROFUNDIDADE } \\
(\mathrm{cm})\end{array}$ & MATERIAL \\
\hline 0 & Superfície & 0 peças \\
\hline 01 & $0-10$ & 0 peças \\
\hline 02 & $10-20$ & 09 peças \\
\hline 03 & $20-30$ & 17 peças \\
\hline 04 & $30-40$ & 0 \\
\hline 05 & $40-50$ & 0 \\
\hline
\end{tabular}




\begin{tabular}{|l|l|l|}
\hline 06 & $50-60$ & 0 \\
\hline 07 & $60-70$ & 0 \\
\hline 08 & $60-70$ & 0 \\
\hline
\end{tabular}

Tabela 04: Unidade de Escavação 02 - BES II / Fev 2010

No sítio BES III, na segunda intervenção arqueológica, foi feita uma unidade de escavação 1 X $1 \mathrm{~m}$ a uma distância aproximada de $50 \mathrm{~m}$ ao sul da primeira intervenção de 2003. Assim como essa última, sua profundidade também atingiu os $40 \mathrm{~cm}$, onde se encontra o embasamento rochoso. Foram coletadas 3 peças em superfície, 9 peças no nível artificial $1(0$ a $10 \mathrm{~cm})$ e 10 peças no nível artificial $2(10$ a $20 \mathrm{~cm})$. Este foi o nível selecionado para a coleta de amostra para datação por LOE.

O sítio Dois Córregos foi identificado durante prospecção arqueológica para duplicação da rodovia SP - 225 de Jaú a Itirapina. Os trabalhos de delimitação, ocorridos em 2005 e realizados pela Scientia Consultoria Científica, demonstraram que o material se distribui em superfície, na média vertente, por uma área total de 5.500 m².

Foram identificadas quatro áreas com material arqueológico:

- Área A: apresenta maior concentração e densidade de material, em área de $3.500 \mathrm{~m}^{2}$, onde se pôde observar que a produção dos instrumentos era realizada neste local, pois estão presentes diversos elementos da cadeia operatória de lascamento (blocos, lascas de diversas dimensões, micro-lascas, estilhas);

- Área B: apresenta baixa densidade de material, em área de $900 \mathrm{~m}^{2}$, talvez uma zona de atividade específica relacionada ao espaço principal de ocupação;

- Área C e D: duas ocorrências isoladas, que podem ser consideradas periféricas ou, ainda, tratar-se apenas de material isolado e certamente deslocado a partir das demais concentrações.

O corte-teste realizado demonstrou a presença de material arqueológico até 0,40 m de profundidade. A estratigrafia indicou um único nível de sedimento arqueológico sem alteração de cor ou textura do solo. O material em superfície está disperso, mas apresenta uma área com maior concentração. Provavelmente, estes vestígios ocupavam áreas menores antes da perturbação causada pelas atividades agrícolas, porém, as análises de laboratório 
ainda permitiram delimitar áreas de atividade, como pode ser visto no capítulo destinado a análise tecnotipológica.

A estratégia adotada no resgate do sítio foi a coleta total mapeada do material presente em superfície, com auxílio de Estação Total.

Considerou-se que como a área onde se situa o sítio é usada sistematicamente para o cultivo mecanizado de cana-de-açúcar, revolvendo a camada arqueológica, a amostra de material aflorado seria representativa do universo da cultura material presente no local.

A área do sítio foi topografada e o material sinalizado para plotagem individual das peças, evidenciando as áreas de concentração de material. O objetivo foi identificar áreas de concentração e, posteriormente, com as análises de laboratório, verificar sua eventual correspondência com áreas de atividades diferenciadas.

Inicialmente foi aberto um corte teste de $1 \mathrm{x} 1 \mathrm{~m}$ para verificar a profundidade da ocorrência dos vestígios. A tabela abaixo apresenta o resultado obtido:

Tabela 05: Descrição da Unidade de Escavação (1 x 1 m)

\begin{tabular}{|c|c|c|}
\hline NÍVEL & $\begin{array}{c}\text { PROFUNDIDADE } \\
(\mathrm{cm})\end{array}$ & MATERIAL \\
\hline 0 & Superfície & 18 peças \\
\hline 01 & $0-10$ & 35 peças \\
\hline 02 & $10-20$ & 20 peças \\
\hline 03 & $20-30$ & 04 peças \\
\hline 04 & $30-40$ & 06 peças \\
\hline 05 & $40-50$ & 0 \\
\hline 06 & $50-60$ & 0 \\
\hline 07 & $60-70$ & 0 \\
\hline
\end{tabular}

Sítio Dois Córregos (Scientia, 2005)

Como o sítio esta em uma área de intensa atividade agrícola e os implementos utilizados na preparação do terreno atingem profundidades maiores que $60 \mathrm{~cm}$, revolvendo a camada arqueológica, foi descartada a possibilidade de obtenção de dados significativos relacionados a estratigrafia. 
Toda a área delimitada (áreas A e B) foi percorrida para localização e sinalização com bandeirinhas de todo o material aflorado em superfície. Após a sinalização de todo o material, procedeu-se à coleta individual mapeada, com auxílio de Estação Total (Scientia, 2005).

Para esse sítio não foi realizada uma segunda etapa de campo, isso por conta de suas condições não favoráveis aos objetivos da intervenção - mencionados anteriormente - que exigiam uma estratigrafia relativamente conservada.

O material coletado na segunda etapa de campo não foi incluído na análise apresentada neste trabalho. Contudo, isso não interferiu na interpretação, sendo que após sua triagem verificou-se que não houve alteração no padrão da coleta realizada em 2003. Ou seja, as características do material arqueológico se mantiveram a mesma.

\section{II.3) Laboratório}

Para a análise laboratorial, houve uma "mescla" de influências, mais antigas e recentes, isso por conta do caráter em que ela se deu. Como destacamos, os sítios foram alvo de resgate arqueológico, e os trabalhos executados por empresas diferentes. Dessa maneira, quando a análise foi realizada, houve o emprego de metodologias distintas. As análises dos sítios BES privilegiaram um caráter mais tipológico, enquanto a do sítio Dois Córregos se focou mais no enfoque tecnotipológico. Assim, registramos aqui os autores consultados nessa fase, acrescidos de nossa visão.

Como para essa pesquisa optamos pelo olhar tecnotipológico, as coleções dos sítios BES II e BES III foram re-analisadas de modo a se padronizar com a coleção do sítio Dois Córregos - que atendia os critérios exigidos em nosso foco -, para que estas pudessem ser comparadas sem problemas.

Assim sendo, nos pautamos nos conceitos de tecnotipologia, seguindo os métodos de Laming-Emperaire (1967), Brèzillon (1977), Tixier et al (1980), Morais (1983), Caldarelli (1983), Vilhena (1986), Araújo (2001) e Bueno (2007). Além de fontes já

utilizadas à época do resgate dos sítios, foram seguidos esses modelos por serem considerados de boa eficácia e amplamente utilizados. Isso permite manter uma 
uniformidade das análises dos sítios do Estado como um todo, garantindo assim, comparações mais confiáveis.

No trato com a tecnologia lítica, vale ressaltar a significação que damos ao conceito de tecnologia. Dois sentidos para essa palavra se destacam mais. O primeiro define tecnologia como o modo pelo qual o homem procura modificar ou controlar seu ambiente natural (Pfaftenberger, 2001 apud Bueno, 2007). Essa visão é de forte cunho adaptativo e determinista ambiental. O segundo sentido caracteriza a tecnologia não só como uma relação homem-ambiente, mas também homem-homem, pois envolve em todas as suas etapas, desde a produção de um artefato até seu descarte, uma série de opções possíveis de serem empregadas. Nesse sentido, o que condiciona todo o processo é a escolha. Assim, as ações são sempre realizadas em uma matriz social e, portanto, carregadas de significado. Por isso, toda e qualquer atividade tem significado cultural e a tecnologia é considerada, portanto, uma construção social e não mais índice de adaptabilidade (Silva, 2000).

Para M. Mauss, a técnica é qualquer ato eficaz e tradicional, sendo o corpo o primeiro e mais natural objeto e meio técnico do homem. Isso está fundamentado na consideração de tecnologia como sistema simbólico de representação, pois enfatiza o fato de que as técnicas corporais são culturalmente apreendidas, e dessa maneira, os gestos técnicos também o são (Mauss, 1936 apud Bueno, 2007). É assim que se destaca a importância do conhecimento da cadeia operatória, que é a combinação de uma série de gestos técnicos ${ }^{17}$. Como todas essas articulações envolvem escolhas efetuadas em um universo de possibilidades culturalmente constituído, podemos dizer então, que o objetivo é entender a arbitrariedade das escolhas tecnológicas, por quais motivos determinadas escolhas foram feitas em detrimento de outras (Bueno, 2007).

Através dessa visão, a tecnologia não é encarada como um instrumento, como meio pelo qual o homem viabiliza sua subsistência e domina o meio natural. "Ela esta envolvida na criação e manutenção das relações sociais que compõe a sociedade. Engloba uma série de atividades relacionadas à produção e transmissão de conhecimento, à negociação de poder e à construção e definição de identidades sociais” (Bueno, 2007: 17).

\footnotetext{
${ }^{17}$ Esse termo, que dá ênfase a seqüência operacional, foi apropriado pela Arqueologia embora tenha surgido na Etnologia. Um dos principais autores nesse processo foi Leroi-Gourhan em trabalho de 1964 (BUENO, 2007).
} 
Dessa forma, identificar possíveis mudanças e/ou continuidade somente a partir da cultura material só é possível por meio de um cuidadoso, minucioso e contextual estudo das escolhas tecnológicas e suas razões. Nesse sentido, Lucas Bueno (2007) aponta para uma oposição importante entre as duas visões de tecnologia:

Enquanto o conceito de tecnologia como índice de adaptabilidade procurar gerar um cenário macro, organizar a variabilidade em termos adaptativos relacionandoa a diferentes contextos ambientais e definindo leis gerais de comportamento, os trabalhos de antropologia da tecnologia procuram particularizar os comportamentos, expandindo essa variabilidade e relacionando-a a significados culturais específicos (Bueno, 2007: 18).

Assim, Torrence (2001 apud Bueno 2007) afirma que mesmo havendo desavenças entre as duas visões, elas não são excludentes, mas sim complementares. Pensando dessa forma, a tecnologia envolve a solução de problemas identificados como tais pelos seus participantes e não como resultado único de algum tipo de necessidade.

Ainda há a questão do maior ou menor risco. O risco limita a escolha, fato esse que evidencia a articulação dessas duas perspectivas, pois a tecnologia é pensada para realizar uma tarefa, mas os detalhes desse processo são culturalmente definidos (Torrence, 2001).

Compreender as razões da escolha significa compreender os processos envolvidos na geração da variabilidade formal dos artefatos que compõe o registro arqueológico. Seriam então as similaridades e diferenças das seqüências das cadeias operatórias as responsáveis pela geração da variabilidade de designs dos artefatos e conjuntos artefatuais encontrados no registro arqueológico.

O que se demonstra então, é que o design é guiado sempre pela performance, ou seja, de que o comportamento do artesão que efetua essa seqüência de atividades é influenciado pela performance de cada uma delas, incluindo aí todas as atividades pelas quais o artefato passa ao longo de sua história de vida (Schieffer; Skibo, 1997:29).

Usar a abordagem tecnológica, buscando respostas técnicas faz com que se evite cair no erro tipológico da classificação, que nos leva a atribuir funções aos objetos que refletem mais a idéia do pesquisador que do valor real do objeto técnico (Jobim, 2007). 
Nessa ótica, é preciso perceber, por exemplo, que um instrumento não se reduz ao artefato. É preciso defini-lo como uma entidade mista: ele é composto por uma entidade artefatual e um componente ligado ao esquema de utilização. Assim:

O artefato não é em si um instrumento, ou componente de um instrumento, ele é instituído como instrumento pelo sujeito que lhe dá seu status de meio para atingir os fins da ação (Jobim, 2007:123).

Para se realizar qualquer estudo de um artefato deve-se fazer sua análise considerando três perguntas: “do que é feito”, “como ele trabalha” e "para que ele serve”. Ou seja, deve-se conhecer sua estrutura, seu funcionamento e sua função. Todo objeto é portador de um esquema de funcionamento. Esse esquema é a essência desse objeto e é a razão de sua existência. A partir desse conhecimento, em vez de se privilegiar o estudo da produção e da função de um objeto, passamos a considerar, também, o funcionamento do instrumento (Rabardel, 1995 apud Jobim, 2007).

Um objeto, por sua vez, pode ser decomposto em três partes:

A - uma parte receptiva de energia que põe o instrumento em funcionamento;

B - uma parte preensiva que permite ao instrumento funcionar; ela pode em certos casos se superpor à primeira;

C - Uma parte transformativa (Lepot, 1993 apud Boeda, 1997).

Cada uma dessas partes é constituída de uma ou de várias Unidades TecnoFuncional (UTF), que são definidas como um conjunto de elementos e/ou características técnicas que coexistem em uma sinergia de efeitos. Nos instrumentos líticos lascados, as UTF's são determinadas pela evidenciação de uma organização particular de retiradas, cujas conseqüências técnicas agem em sinergia para colocar uma característica técnica remarcável e coerente (Jobim, 2007).

Através desse arcabouço teórico o material lítico dos três sítios estudados foi analisado.

As estatísticas foram todas elaboradas e trabalhadas a partir do programa EXCEL 2007. 


\section{CAPÍTULO III - DELIMITAÇÃo DA ÁREA GEOGRÁFICA E CARACTERÍSTICAS AMBIENTAIS}

\section{III.1) Ambiente}

Podemos separar a área destinada a pesquisa em duas micro-regiões. A primeira está inserida na região centro-oeste do Estado de São Paulo, na parte onde se projeta a sub-bacia hidrográfica do rio Jaú, apresentando quase $400 \mathrm{~m}$ de amplitude altimétrica, sendo o ponto mais elevado (820 m) encontrado próximo às cabeceiras, na serra do Tabuleiro, e o mais baixo (440 m) na embocadura com o rio Tietê, na represa de Bariri. Encontramos no intermédio desse curso os municípios de Brotas, Dois Córregos, Bocaína, Itapuí e Boracéia, onde os principais sistemas hídricos são representados pelas sub-bacias dos rios JacaréGuaçu, Jacaré-Pepira e Jaú, todos os quais, são afluentes do Rio Tietê por sua margem direita.

A segunda área a ser pesquisada está no alto e médio curso do Rio Jacaré-Guaçu, onde se encontram os municípios de Boa Esperança do Sul e Gavião Peixoto. Destaca-se nesse rio sua extensa várzea no limite dos municípios de Araraquara e Boa Esperança do Sul, com grandes áreas de vegetação herbácea. Nesta bacia, além deste rio há o seu afluente Ribeirão Chibarro e outros pequenos cursos d'água pertencentes à sub-bacia deste último.

\section{III.2 - Geologia e Geomorfologia}

Geologicamente toda essa região está inserida na Bacia Fanerozóica do Paraná, com litologias do Mesozóico, como rochas das formações Pirambóia, Botucatu e Serra Geral, pertencentes ao Grupo São Bento e outras ao Grupo Bauru, além da Formação Itaqueri e depósitos correlatos (Palanca, R. T. S. \& Koffler, N. F, 1996 e Scabello, 1997). 


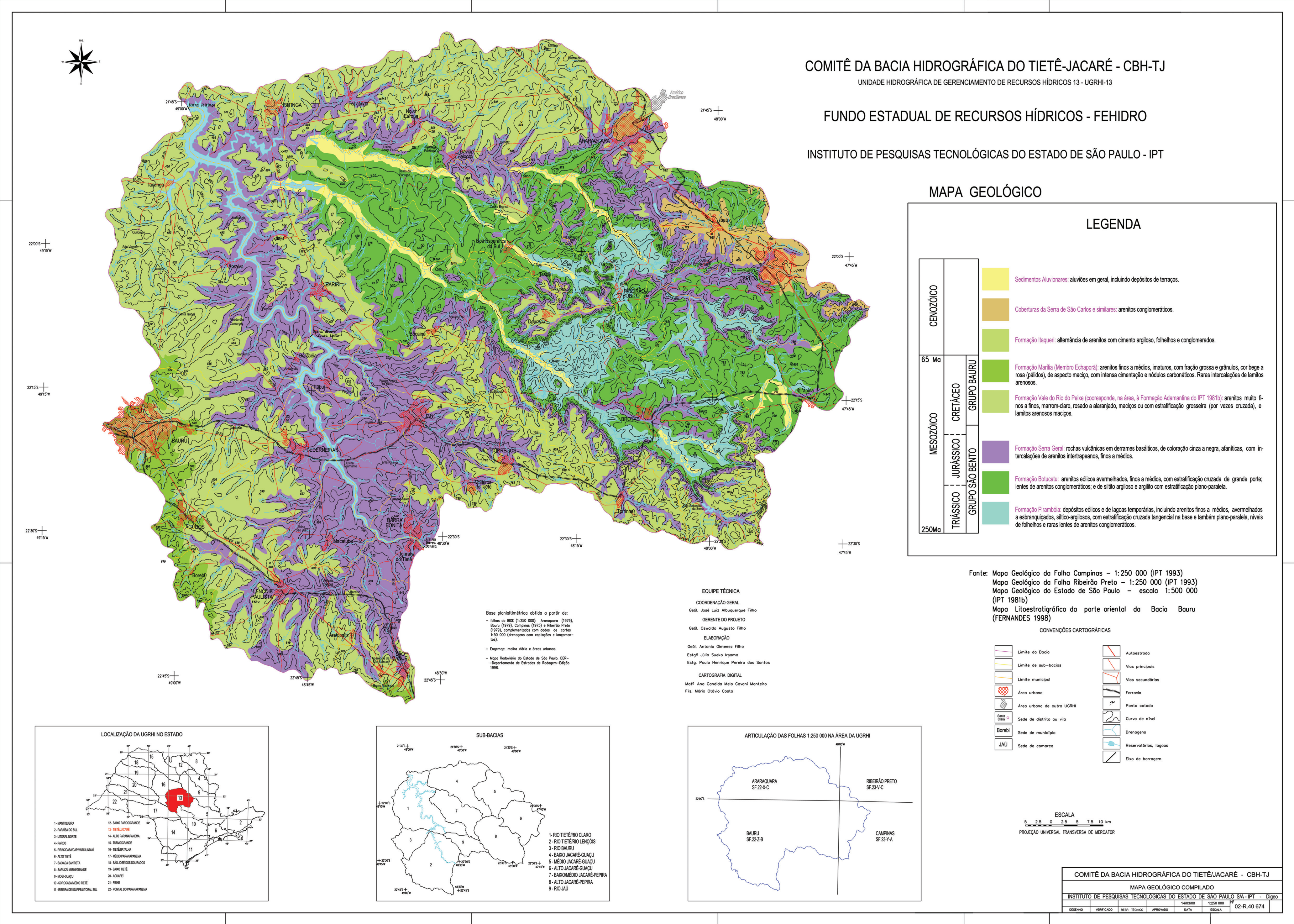




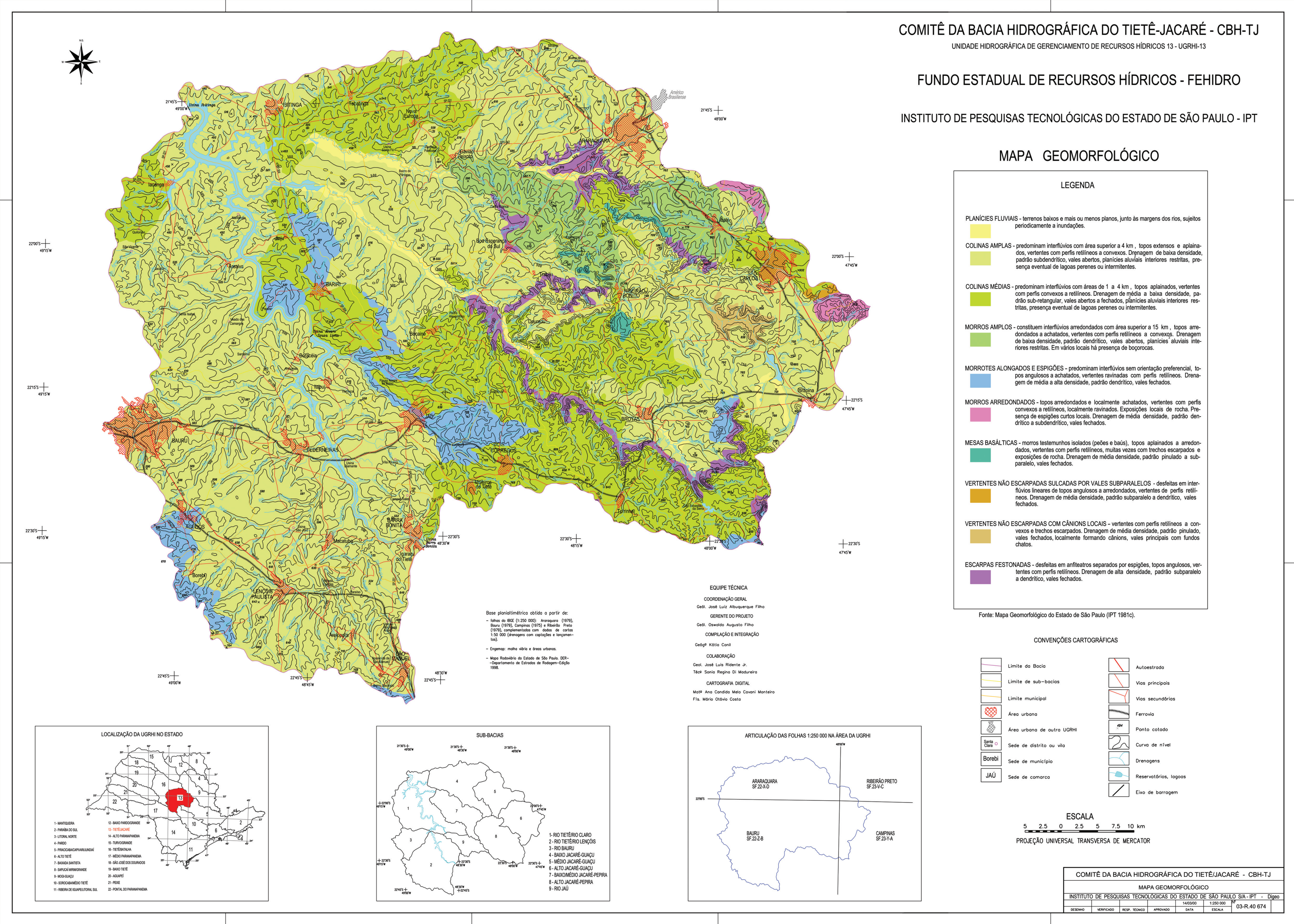




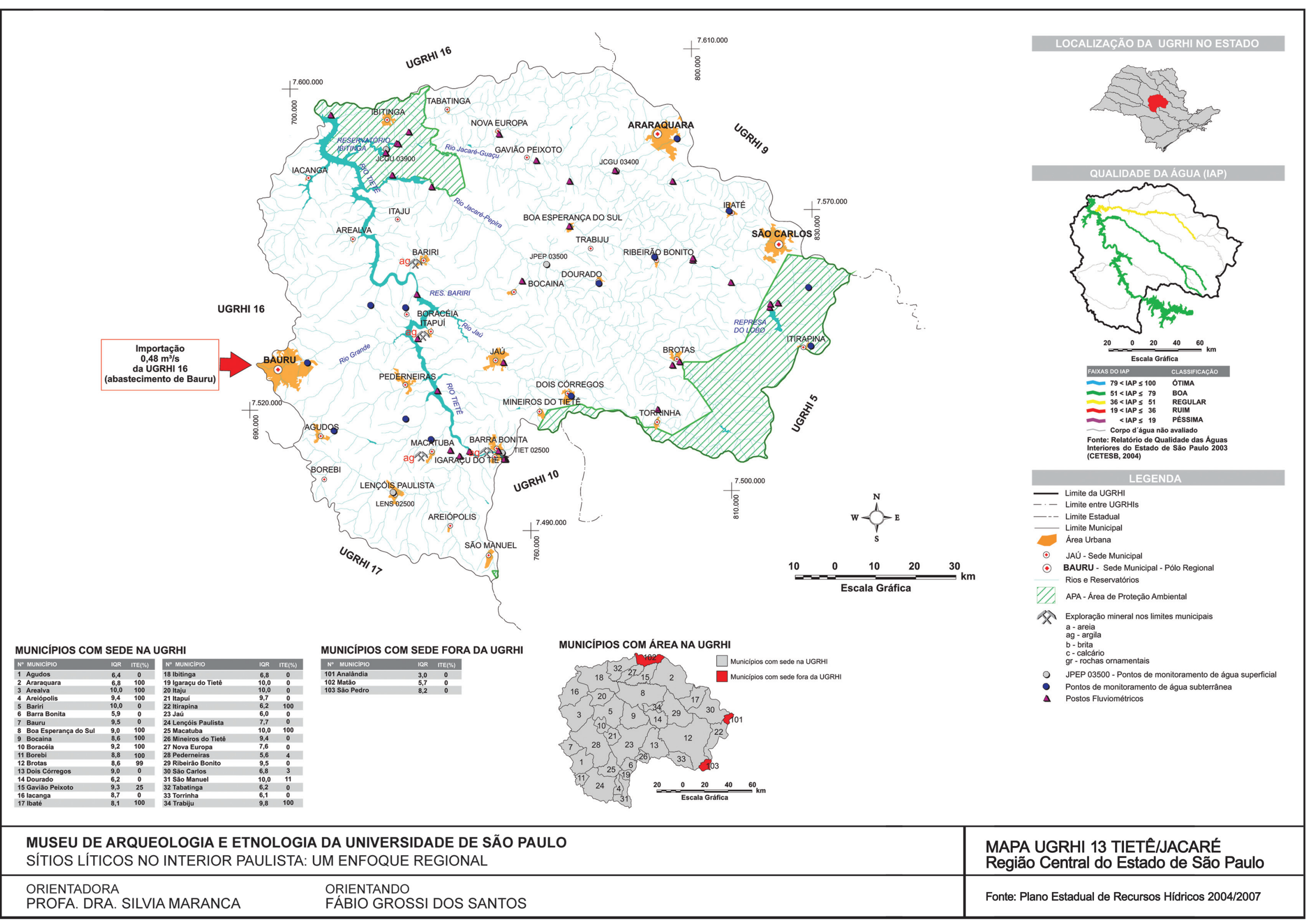




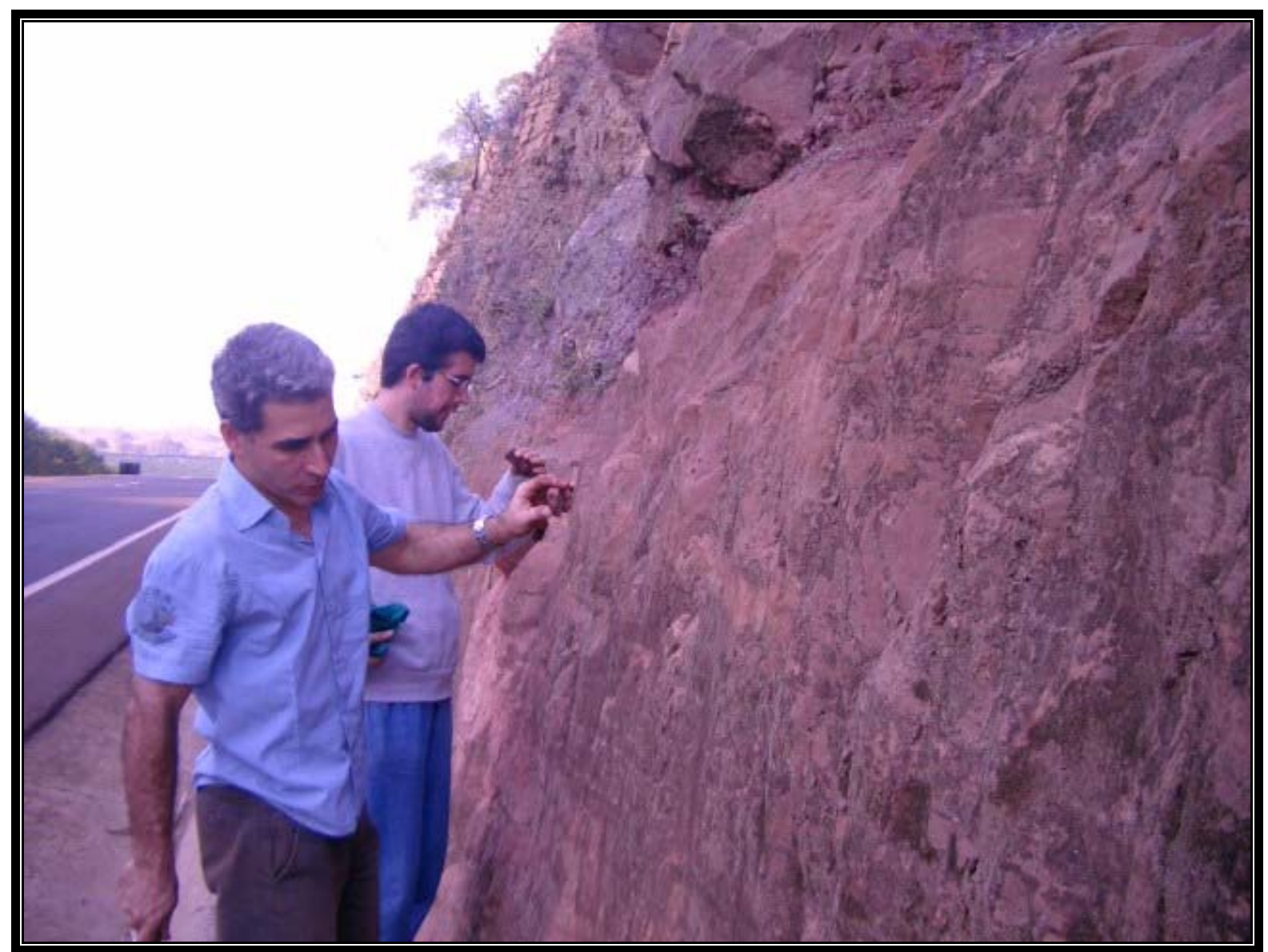

Imagem 03: Afloramento arenítico em estrada de acesso a Boa Esperança do Sul, próximo ao sítio BES II (coordenadas em UTM 22k 0803301/7583399 - datum SAD 69).

A área em análise pertence a província geomorfológica denominada Cuestas Basálticas, no limite com a chamada Depressão Periférica. As modalidades de relevo identificadas na região são as colinas médias, Morrotes alongados e espigões. E os tipos de solos predominantes são os Latossolos, Terras Roxas, Solos Podzólicos, Areias Quartzosas e Solos Litólicos.

A cobertura vegetal predominante é a Floresta Mesófila Semidecídua seguida por manchas de cerrado (Palanca, R. T. S. \& Koffler, N. F, 1996; Zanettini, 2003; Caldarelli, 2005). No início da década de 1970, quando foram produzidos os mapas do IBGE em escala 1:50.000, os fragmentos florestais haviam sido substituídos em grande parte por cultivos de café, cana, eucalipto, milho e campos (possivelmente para criação de animais). Na atualidade, a cana-de-açúcar prevalece, permanecendo intactas as áreas de relevo acidentado, que são pouco agricultáveis. 
Considerando a macro-região, os sítios arqueológicos de Boa Esperança do Sul e Dois Córregos, assim como outros identificados em Gavião Peixoto, Boracéia e Jaú estão todos inseridos na Bacia do Rio Tietê em seu médio/baixo curso.

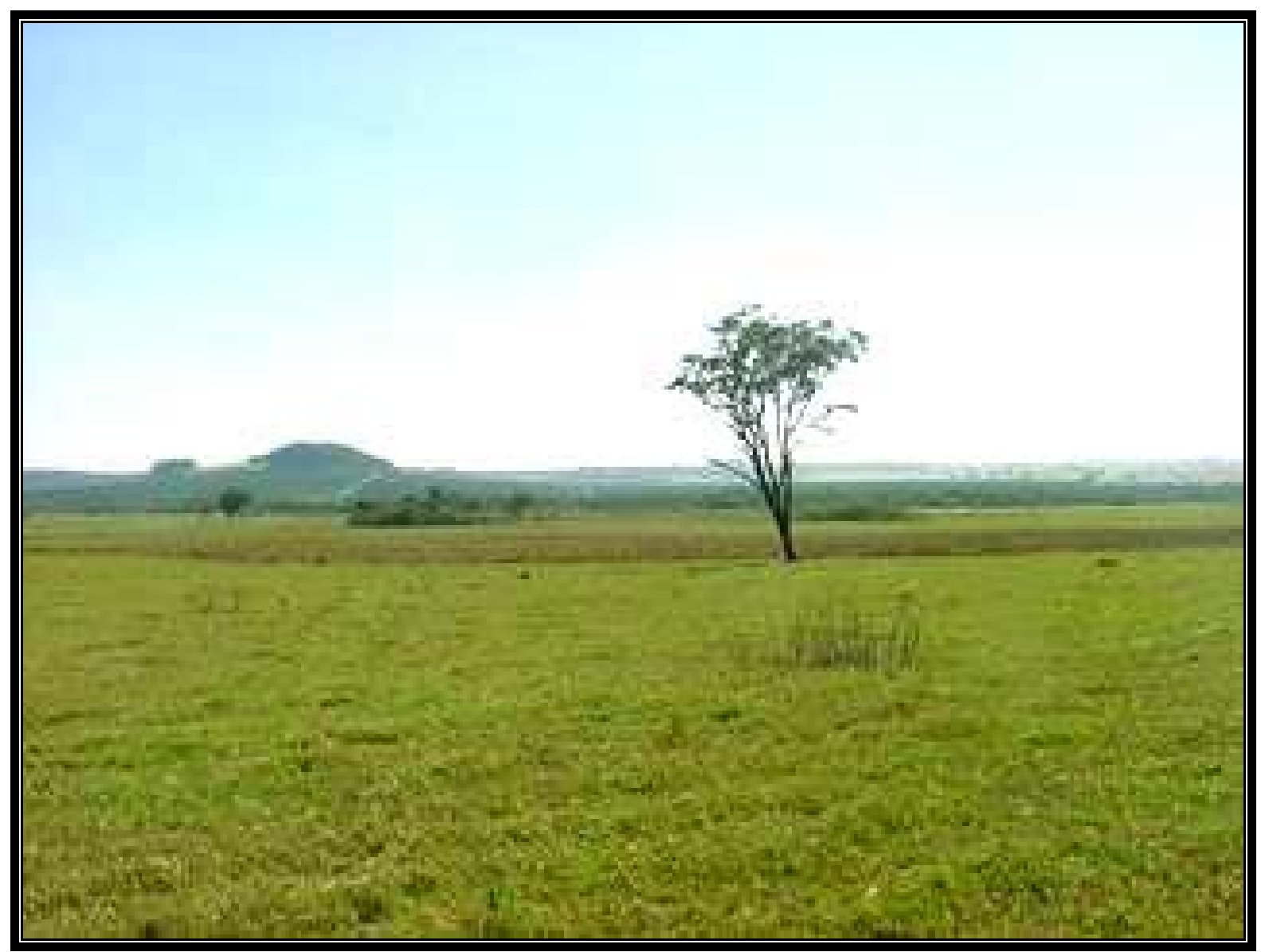

Imagem 04: vista da área do sítio BES II (Zanettini, 2003) 


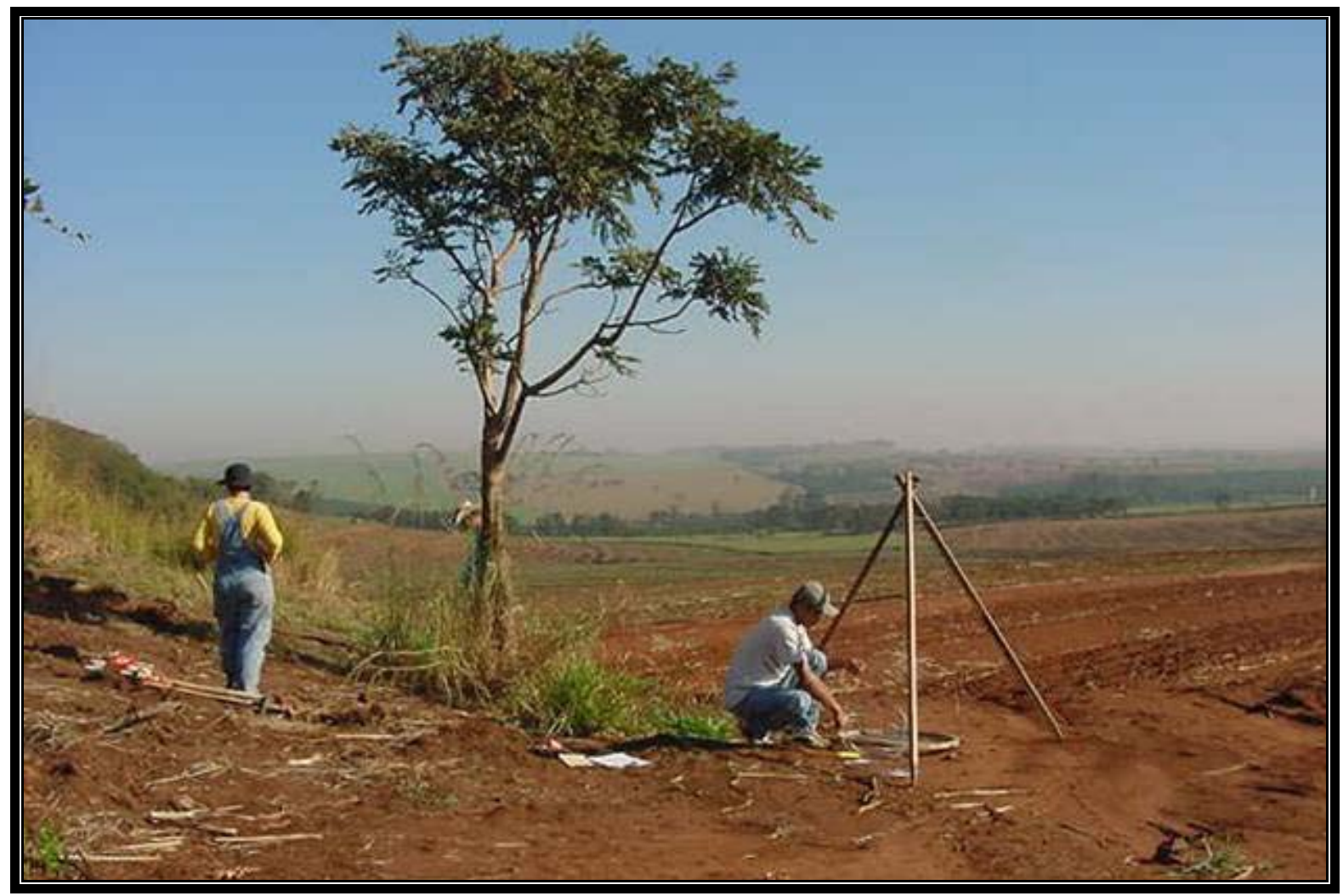

Imagem 05: Vista a partir do sítio BES III (Zanettini, 2003) 


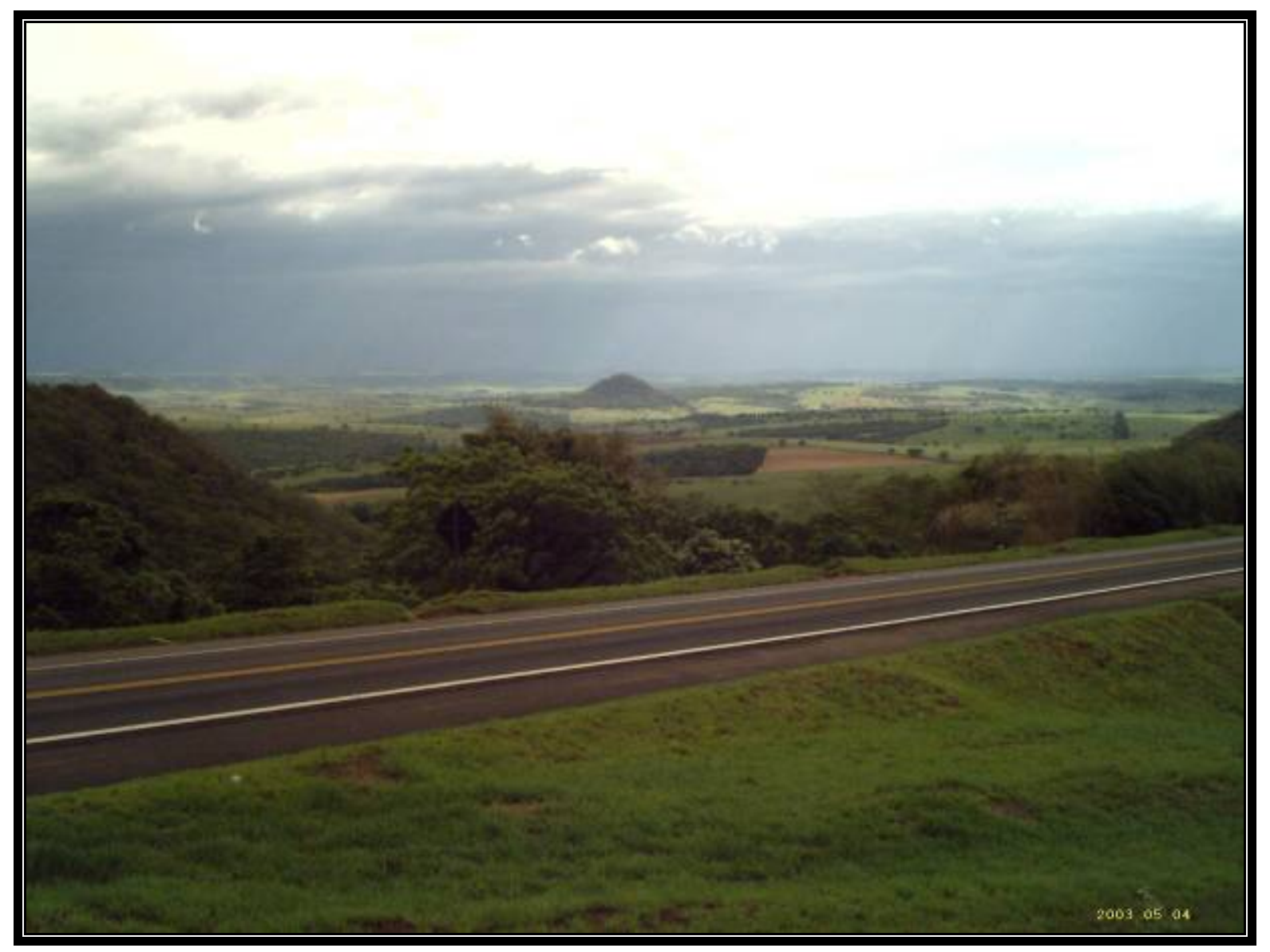

Imagem 06: vista a partir do sítio Dois Córregos (Scientia, 2005)

A delimitação da área da pesquisa foi feita a partir do panorama arqueológico regional que se planejou obter, seguindo pontos traçados com potencial para ocupação préhistórica e seguindo um perímetro territorial de 100 quilômetros, que foi estabelecido a partir da cidade de Jaú, definida como referência central. Perímetro esse que está de acordo com a média de deslocamento conhecida entre os caçadores-coletores demonstrada em textos com o enfoque na mobilidade.

\section{CAPÍTULO IV - OS SÍTIOS ARQUEOLÓGICOS}

Os três sítios selecionados para análise possuem algumas características em comum que merecem destaque. Em seu contexto ambiental, no que se refere à Geologia, estão inseridos na Bacia Sedimentar do Paraná, suas áreas estão inseridas onde há a presença da Formação Botucatu, Serra Geral e Adamantina. Estão na Compartimentação 
Geomorfológica do Estado de São Paulo, nas províncias morfológicas das Cuestas Basálticas e Planalto Ocidental, em limites com a Depressão Periférica.

A vegetação mais comum é o cerrado e atualmente há a agricultura, que ora se mostra na cultura da cana-de-açúcar, ora em pasto.

Todos são assentamentos a céu aberto, e fica evidente, nos três casos, que um dos principais fatores para a escolha do espaço de ocupação dos grupos humanos que por ali passaram foi a proximidade com a fonte de matéria-prima para a confecção de seus utensílios. A grande oferta local de boa matéria-prima para lascamento foi condição preponderante para a instalação humana nesse caso. Outra característica é a proximidade a um curso d’água. Nos sítios BES II e III temos o Rio Jacaré-Guaçu bem próximo e no sítio Dois Córregos há em suas proximidades, embora pequeno, um curso d’água, tendo como rio mais próximo, o Jacaré-Pepira.

Segue a descrição de cada um dos sítios:

\section{Sítio Boa Esperança II}

O Sítio Boa Esperança II constitui-se em um assentamento lítico a céu aberto, identificado durante a etapa de diagnóstico arqueológico realizado na região, apresentando excelente estado de conservação e proporções consideráveis, distribuindo-se os vestígios por uma área superior a $30 \mathrm{mil} \mathrm{m}^{2}$, conforme o avanço das pesquisas na área originalmente delimitada. O sítio está localizado na Fazenda São Pedro do Jacaré, em propriedade do Sr. Francisco Pedro Monteiro da Silva Filho, atualmente Piscicultura do Jacaré (Pesque \& Pague).

O sítio está implantado em baixa vertente, à margem esquerda do rio Jacaré-Guaçu, assentado em terraço fluvial raso sobre sedimentos aluvionares quaternários, entrecortado por meandros abandonados do leito do rio e próximo a uma cascalheira.Suas coordenadas em UTM com datum córrego alegre são 22k 0780487 / 7578507.

Este sítio destca-se devido à quantidade expressiva de evidências verificadas em superfície e a diversidade de matérias-primas utilizadas para lascamento (arenito silicificado, seixos de quartzo e sílex). Concorreu para o aprofundamento do estudo o fato da área ter sido submetida a poucas intervenções, sendo utilizada como pastagem há pelo 
menos cinco décadas, segundo depoimento de seus proprietários. Apenas em dois pontos constatou-se que ocorreu no passado a extração de argila e retirada de seixos para obras de pavimentação/conservação da rodovia.

As escavações demonstraram a existência de dois níveis distintos de deposição do material arqueológico: um mais superficial, variando entre $0-30 \mathrm{~cm}$, exposto em parcela do sítio em virtude da movimentação de terra promovida em sua porção Norte e, outro nível bem mais profundo, atestado nas cotas mais elevadas do terraço, variando entre 1,4 e 1,8m, sugerindo estarmos lidando com duas ocupações temporalmente distintas e afastadas no tempo, todavia, indicando, de imediato a intensa utilização dessa área no passado, fato que aponta para a importância de se dar continuidade nos estudos.

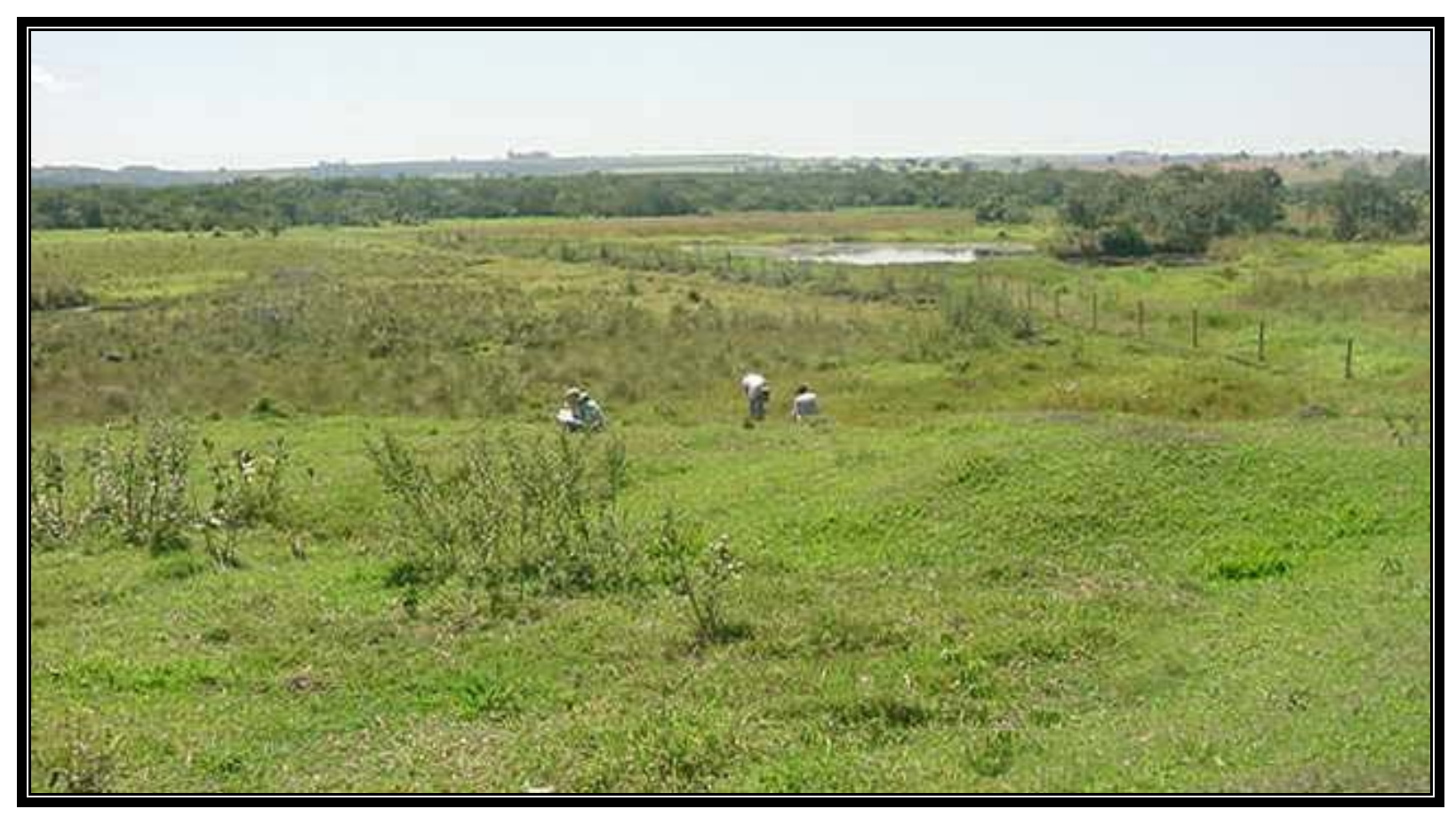

Imagem 07: localização do Sítio BES II (Zanettini, 2003) 


\section{Sítio Boa Esperança III}

O Sítio Boa Esperança III é outro assentamento lítico a céu aberto, com excelente estado de conservação e pequena extensão, em torno de $600 \mathrm{~m}^{2}$, apresentando exclusivamente artefatos e lascas em arenito silicificado. O sítio BES III está implantado no topo de pequena colina preservada, associada a afloramento rochoso, situado em meio a um canavial. Suas coordenadas em UTM com datum córrego alegre são 22k 0778822 / 7578734.

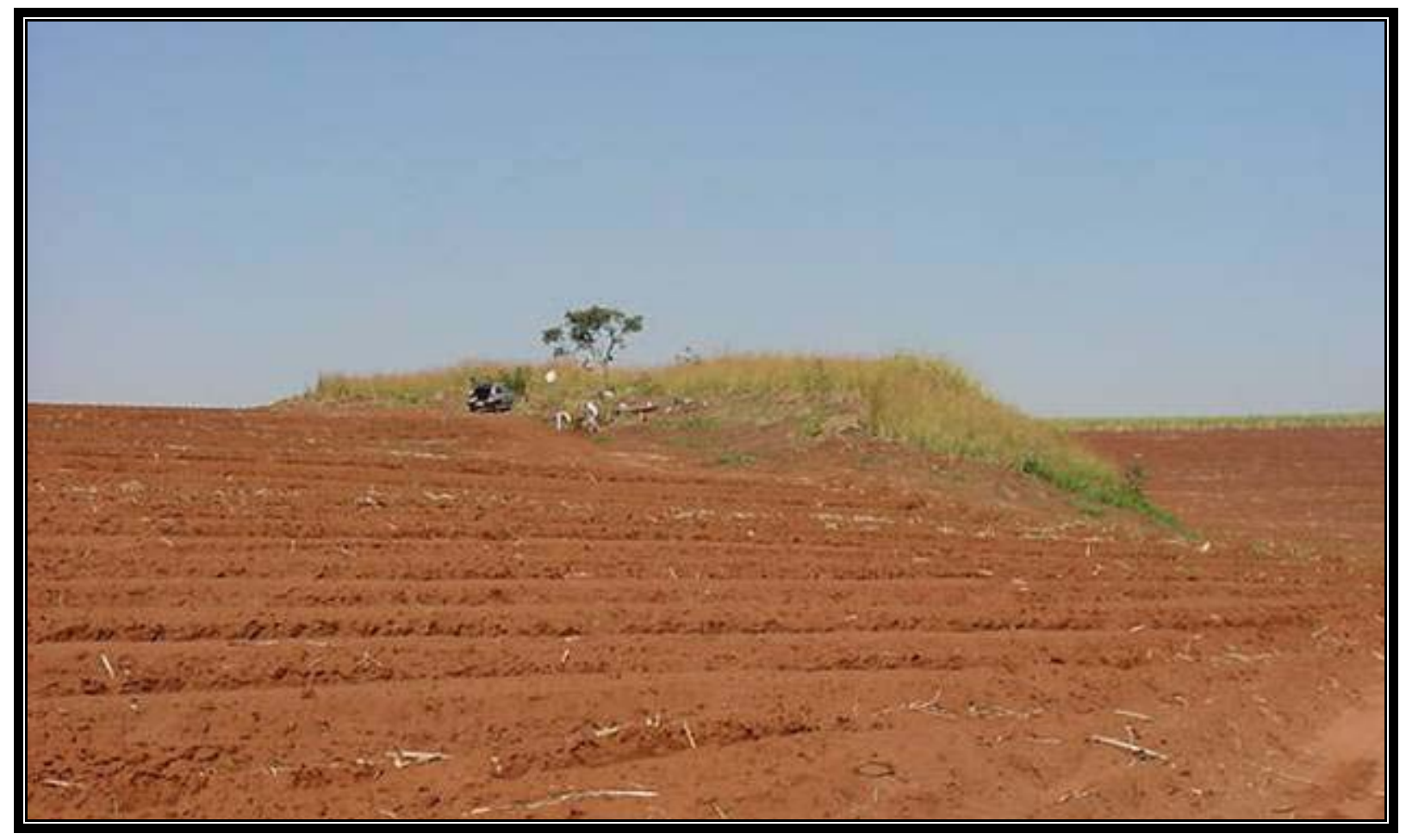

Imagem 08: localização Sítio BES III (Zanettini, 2003)

\section{Sítio Dois Córregos}

O terceiro assentamento a céu aberto está implantado em média vertente de colina e o material lítico está presente nas laterais de ambas as pistas da rodovia SP-225 (Km 156+500 m a Km 156+800 m), mais concentrado na lateral da pista sentido Jaú-Itirapina, o que indica que o sítio arqueológico já havia sofrido interferência quando da implantação da 
pista existente. Está localizado próximo a um afloramento rochoso de basalto onde ocorrem veios de arenito silicificado, a principal fonte de matéria-prima usada neste sítio. Suas coordenadas em UTM com datum SAD 69 são 22k 0772379 / 7537206.

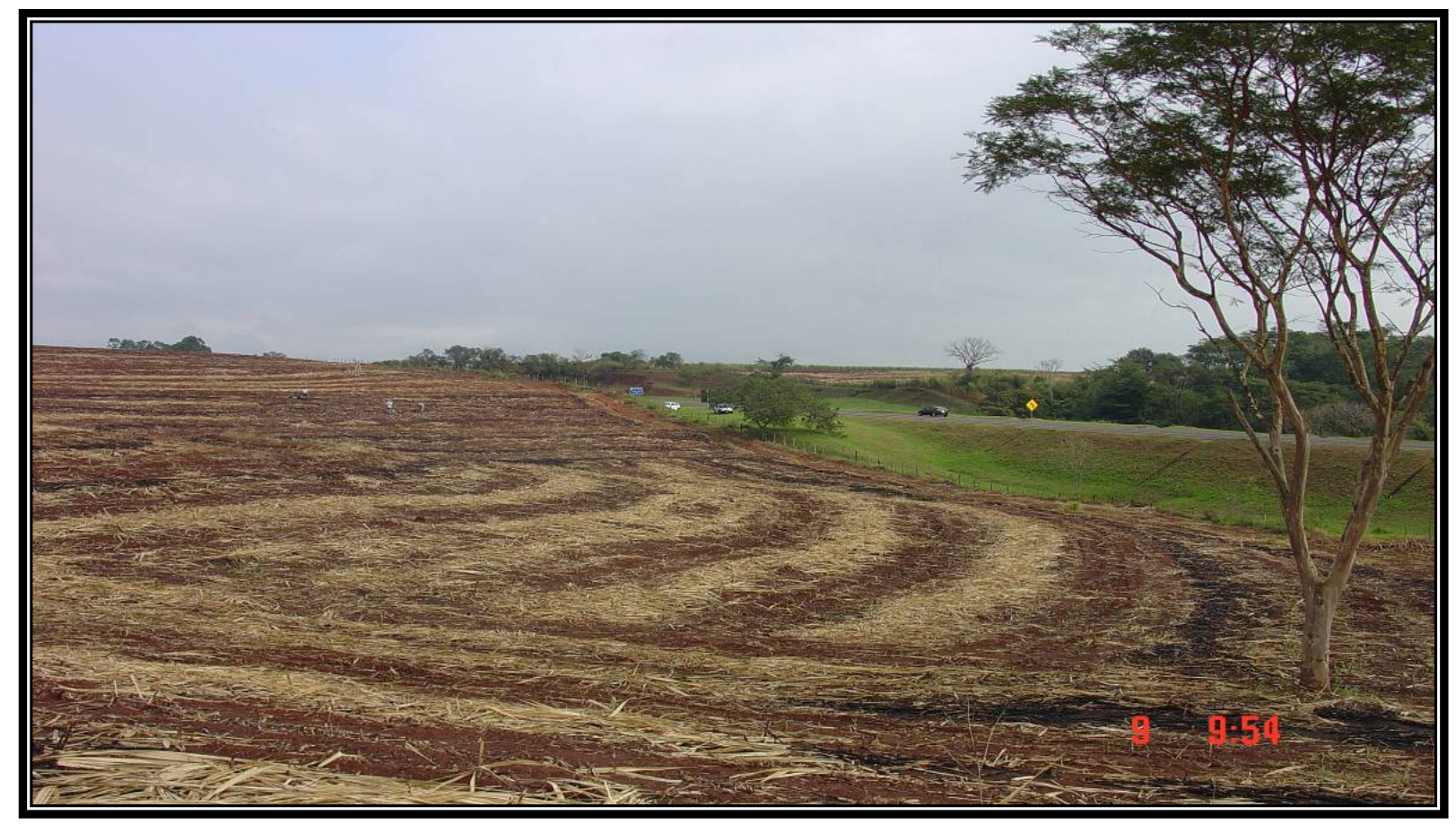

Imagem 09: Localização Sítio Dois Córregos (Scientia, 2005) 

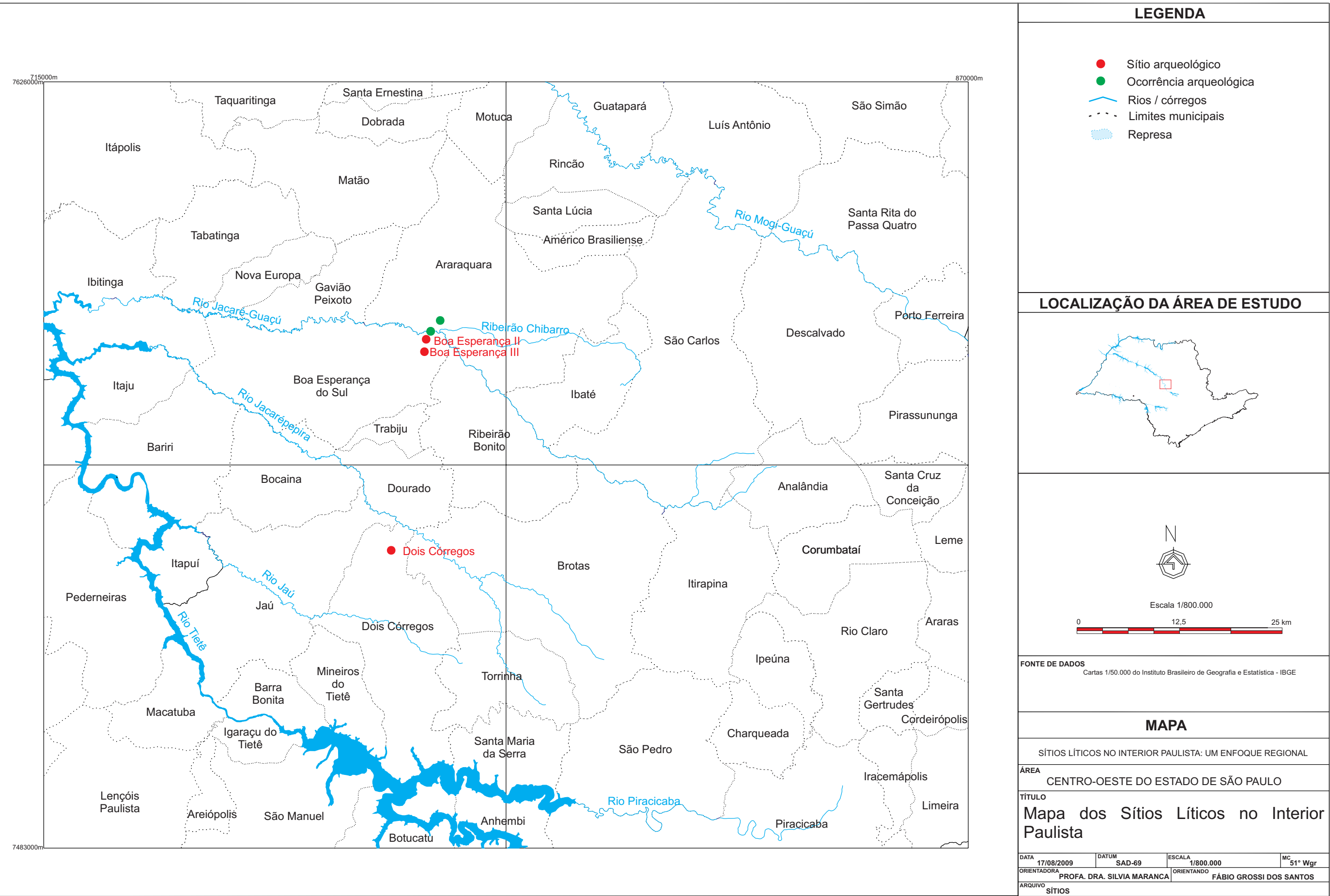


\section{IV.1) A Indústria Lítica: Tecnotipologia}

A análise das lascas unipolares foi feita seguindo os seguintes critérios:

1 - Matéria Prima:

Arenito Silicificado

$>$ Arenito

$>$ Sílex

$>$ Silexito

$>$ Quartzo

$>$ Quartzito

$>$ Basalto

$>$ Conglomerado

$>$ Outros

2 - Alteração térmica

$>\mathrm{Sim}$

$>$ Não

> Pátina

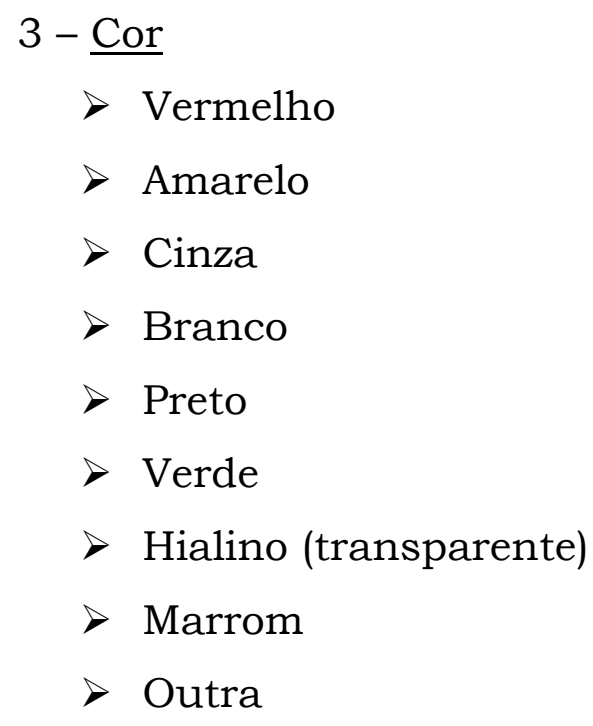


4 - Forma de Apresentação

$>$ Seixo

$>$ Nódulo

$>$ Cristal

$>$ Bloco

$>$ Não identificável

5 - Percentual de Córtex na Face Externa

$>100 \%$

$>75 \%$

$>50 \%$

$>25 \%$

$>$ dorsal

$>$ sem córtex

6 - $\underline{\text { Morfologia do talão }}$

$>$ Liso

$>$ Cortical

$>$ Esmagado

$>$ Linear

$>$ Puntiforme

$>$ Diedro

$>$ Em "U"

$>$ Em vírgula

$>$ Meia lua

$>$ Triangular

$>$ Facetado

$>$ Asa

$>$ Outros

7 - Dimensões da peça 
> Comprimento máximo em relação ao eixo de debitagem

$>$ Largura máxima em relação ao eixo de debitagem

$>$ Espessura máxima

8 - Ângulo do Talão com a Face Interna

$>$ Ângulo fechado (inferior ou igual a 90)

$>$ Ângulo aberto (entre $100^{\circ}$ e $120^{\circ}$ )

$>$ Ângulo muito aberto (superior a $120^{\circ}$ )

9 - Morfologia da Peça

$>$ Quadrangular

$>$ Triangular

$>$ Mais de 4 lados

$>$ Laminar

$>$ Circular

$>$ Sub-circular

10 - Quantidade de Nervuras

$>$ Uma

$>$ Duas

$>$ Três ou mais nervuras

$>$ Sem nervuras

$>$ Duas paralelas

$>$ Em "Y"

$>$ "Y" invertidoo

$>$ Uma paralela ao eixo de debitagem

$>$ Em "T"

$11-\underline{\text { Perfil }}$

$>$ Retilineo

$>$ Convexo 
$>$ Côncavo

$>$ Helicoidal

\section{2 - Acidente de lascamento}

$>$ "Siret"

transbordante

$>$ refletida

$>$ lingüeta

ultrapassante

Para a análise dos produtos de lascamento bipolares que tiveram pouca representatividade, foi observado o estado de conservação da peça. Posteriormente, foram caracterizadas a matéria-prima e sua forma de apresentação. E por fim, a morfologia das lascas (gomo, laminar, prisma, fatiagem) e a quantidade de córtex na face superior.

Os utensílios, ou, os "suportes que apresentam algum tipo de evidência de preparação para utilização (retoques) ou marcas de uso” (Scientia, 2005), foram analisados de acordo com as UTF’s (já explicadas anteriormente). Assim como destaca Astolfo Araújo, de acordo com a abordagem escolhida foi privilegiada a mensuração dos bordos ativos, pois, "por sua flexibilidade, parece mais adequada quando o objetivo é lidar com indústrias líticas expedientes, pouco padronizadas. (...) Esta abordagem também tem a grande vantagem de permitir a observação de co-ocorrências caso elas existam, e ao mesmo tempo não força a atribuição de peças a classes rígidas, resultantes de tipologias morfológicas baseadas em senso comum” (Araújo, 2001: 277). Para a análise descritiva dos utensílios informais foram usados os seguintes atributos inspirados e adaptados do trabalho de Lucas Bueno(2007):

\section{1 - Matéria Prima}

\section{2- Suporte}

$>$ Tipo: Lasca (1), fragmentos de lascamento (2), seixo (3);

Dimensões: Comprimento / Largura / Espessura (mm) 
Extensão Cortical: ausente (0) / menor que $1 / 4$ (1) / menor que 3/4 (2) / total (3)

$>$ Forma: Descrição das faces superior e inferior das lascas antes de sua retirada do núcleo; descrição da forma original do seixo; ou descrição geral do fragmento de lascamento;

3 - Número de Faces Trabalhadas

Uma - unifacial (1) / duas - bifacial (2)

$>$ Número - quantidade de gumes do utensílio

$>$ Ângulo - abrupto, semi-abrupto ou rasante

> Delineamento - retilíneo, côncavo, convexo, com reentrância, denticulado

4 - Módulo Volumétrico

> Prisma triangular, prisma trapezoidal, retangular, semi-elipse, elipse.

$5-\underline{\text { Retoques }}$

> Posição: direto, inverso, bifacial;

> Extensão: submilimétrico, marginais, invasores, envolventes;

> Morfologia: escalariforme, paralelo, subparalelo;

> Repartição: total, parcial;

> Localização: indicação do bordo e a parte do bordo;

$>$ Reavivagem: presente, ausente, sobre pátina.

6 - Técnicas de Percussão

Direta (1), indireta (2)

7 - $\underline{\text { Percutor }}$

Duro (1), macio (2)

8 - $\underline{\text { Função }}$

Simples (1), múltipla (2) 
Para a análise quantitativa dos utensílios:

$$
\begin{aligned}
& \text { A - Extensão do Retoque } \\
& 0 \text { - Submilimétrico } \\
& 1 \text { - marginal } \\
& 2 \text { - invasor } \\
& 3 \text { - envolvente } \\
& \text { B - Delineamento do Gume } \\
& 1 \text { - convexo } \\
& 2 \text { - côncavo } \\
& 3 \text { - Linear } \\
& 4 \text { - côncavo/convexo } \\
& 5 \text { - retilíneo/côncavo } \\
& 6 \text { - retilíneo/convexo } \\
& 7 \text { - outro } \\
& \text { C - Ângulo do Gume } \\
& 1 \text { - rasante }\left(0-20^{\circ}\right) \\
& 2 \text { - Quase rasante }\left(30-50^{\circ}\right) \\
& 3 \text { - Semi-abrupto }\left(60-70^{\circ}\right) \\
& 4 \text { - Abrupto }\left(80-90^{\circ}\right) \\
& \text { D - Posição do Retoque } \\
& 1 \text { - Direto } \\
& 2 \text { - Inverso } \\
& 3 \text { - Bifacial } \\
& 4 \text { - Alternante }
\end{aligned}
$$

E- Repartição

1 - Total

2 - Parcial 
Os produtos de lascamento que não foram trabalhados de forma estatística foram subdivididos nas seguintes categorias:

1 - Núcleos (unipolares e bipolares)

2 - Fragmentos de núcleos

3 - detritos de lascamento

4 - estilhas

5 - fragmentos de lascas

6 - lascas fragmentadas

Todas as peças tiveram seu estado de conservação observado, assim como também tiveram o cálculo do índice, definido como a relação largura, comprimento e espessura, para definir o tamanho das peças. Finalizando, todas as peças foram pesadas.

\section{IV.2) Sítio Dois Córregos ${ }^{18}$}

Foram coletadas 1.068 peças no sítio, sendo 1.002 em superfície e 66 na sondagem. As características do material coletado na sondagem são as mesmas do material de superfície. Foram coletadas 547 lascas, 13 núcleos, 23 instrumentos retocados, 03 percutores, 173 detritos de lascamento, 177 fragmentos de lasca e 132 peças de lítico bruto.

\footnotetext{
${ }^{18}$ A análise do sítio Dois Córregos foi realizada pela Scientia Consultoria Científica (2005). Os dados foram mantidos por estarem de acordo com a proposta de interpretação da presente pesquisa. Apenas a formatação foi alterada de modo a se padronizar com o resto do trabalho. De modo que os créditos desta análise são deles.
} 


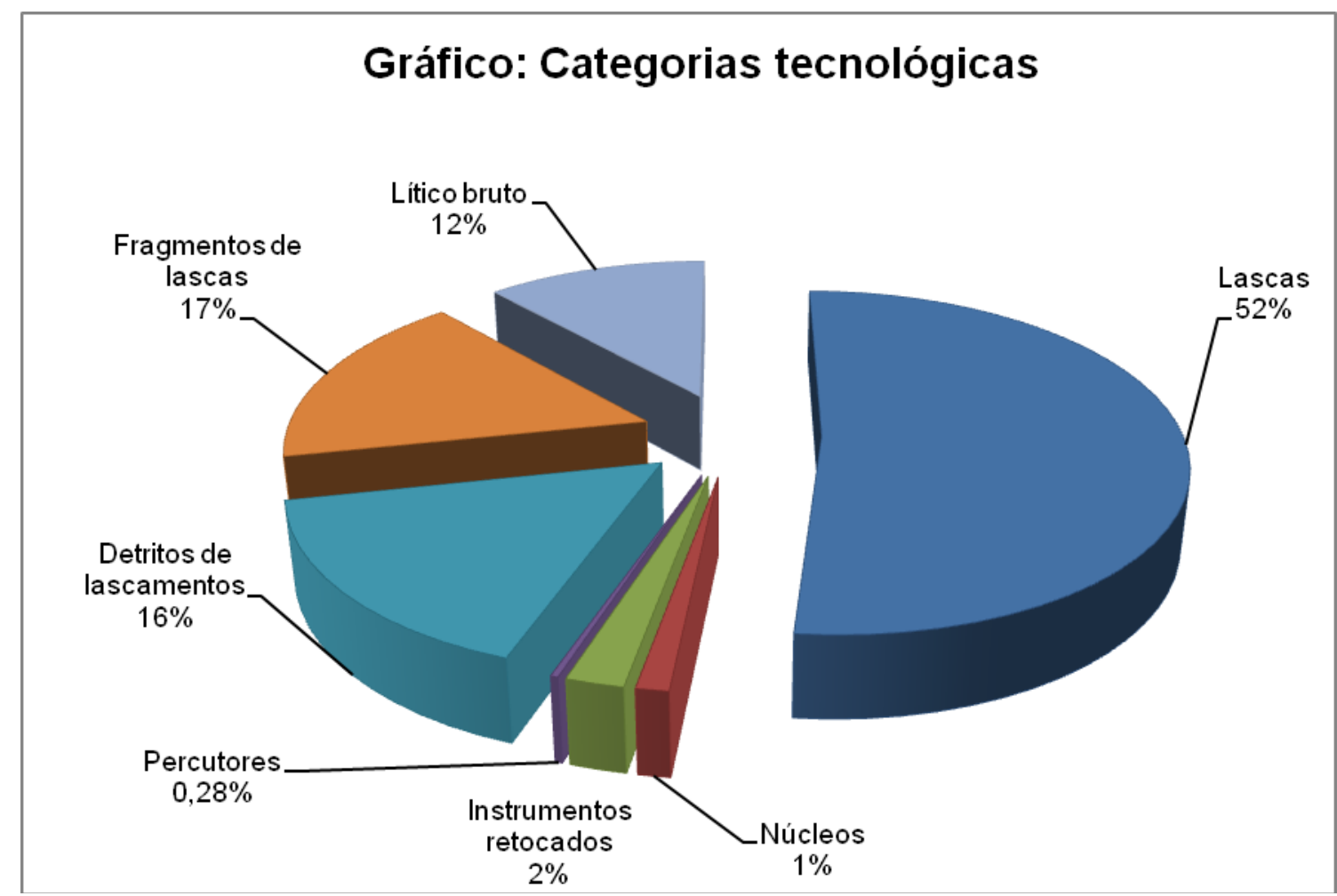

Gráfico 01: Categorias Tecnológicas

Como demonstra o gráfico abaixo, a grande maioria do material coletado é de arenito silicificado (1030 peças - 96,35\%). Na seqüência tem-se o basalto (15 peças $1,4 \%$ ); o silexito (13 peças - 1,22\%); e o quartzo e quartzito (11 peças - 1,03\%). 


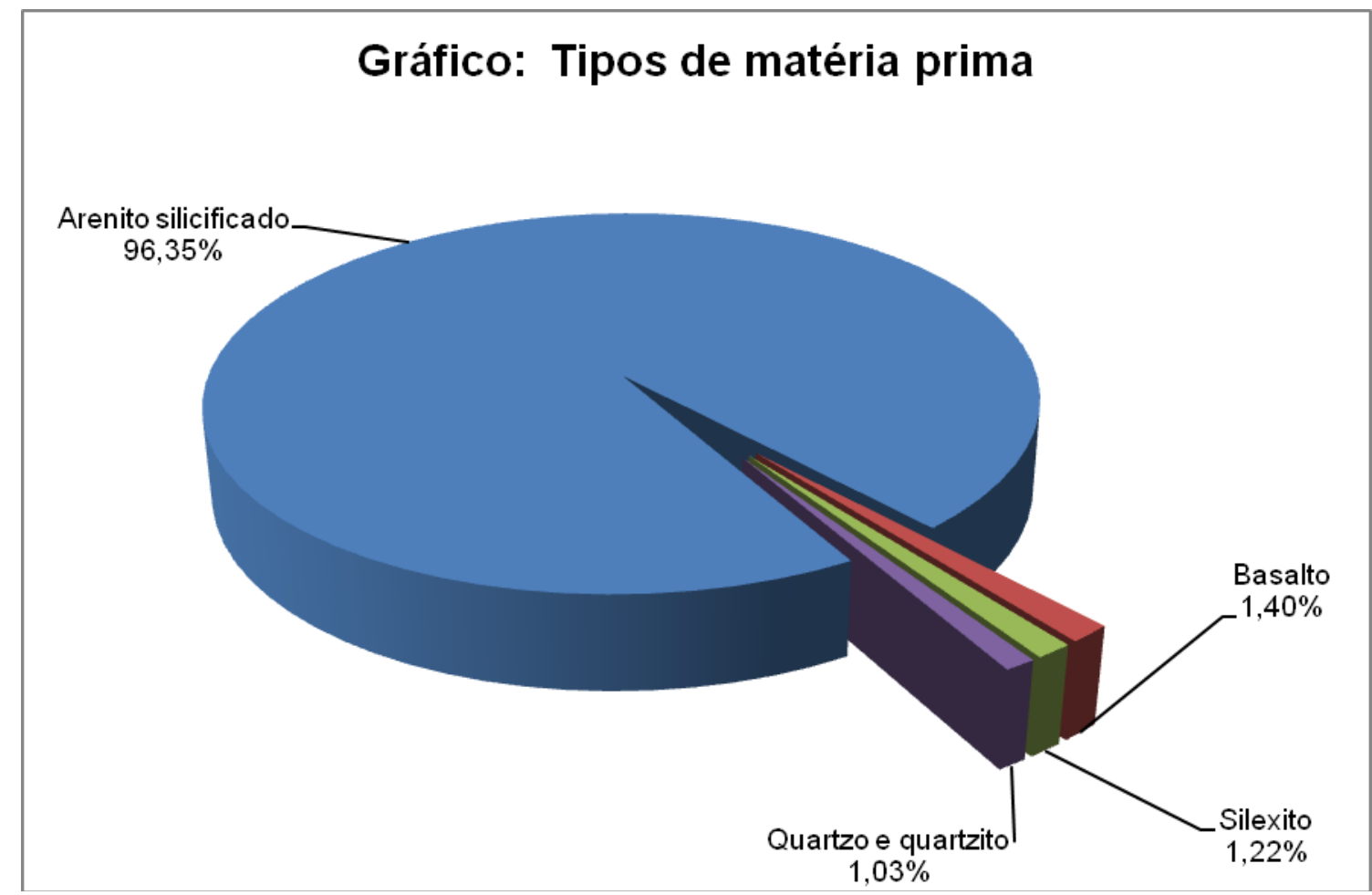

Gráfico 02: Tipos de Matéria-prima

Ainda pode se perceber desse material que 288 peças apresentaram algum tipo de alteração térmica - como cúpulas térmicas - e 9 peças apresentaram pátina. Algumas peças apresentaram também manchas que parecem de algum tipo de óleo.

Observando os exemplares da coleção de núcleos do Sitio Dois Córregos, podemos identificar uma predominância de peças sobre blocos de arenito. Cabe aqui destacar que o sítio está implantado próximo a uma fonte desta matéria-prima. A abundância de arenito proporcionou uma indústria baseada na obtenção de lascas médias (entre 05 a 08 cm de comprimento), sobre as quais a maioria dos artefatos foi retocada. A categoria mais representativa da coleção é a das lascas unipolares com 547 exemplares (300 inteiras e 247 fragmentadas), sendo 538 de arenito silicificado (98,35\%), 06 de basalto $(1,1 \%)$ e 03 de silexito $(0,55 \%)$. 


\section{Gráfico: Matéria prima - Lascas unipolares}

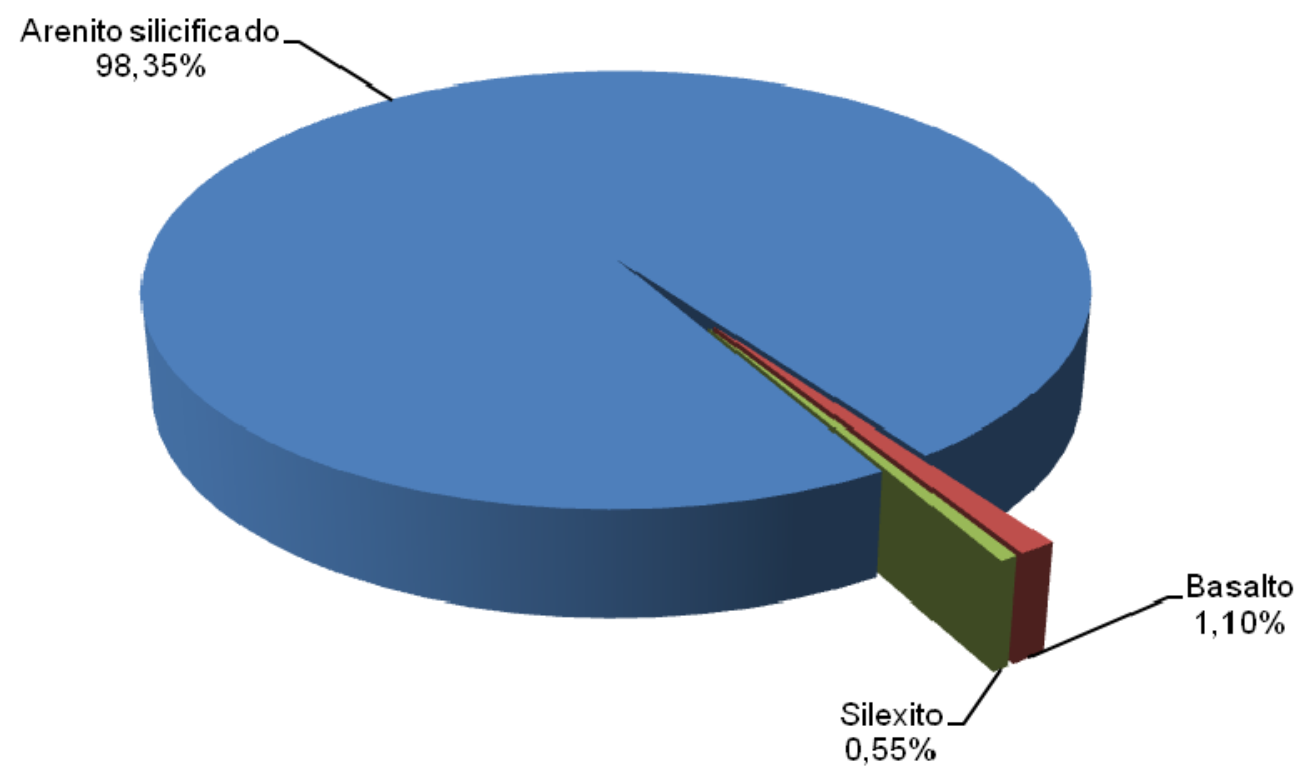

Gráfico 03: Matéria-prima Lascas Unipolares

\section{Gráfico: Índice comprimento x largura: categorias}

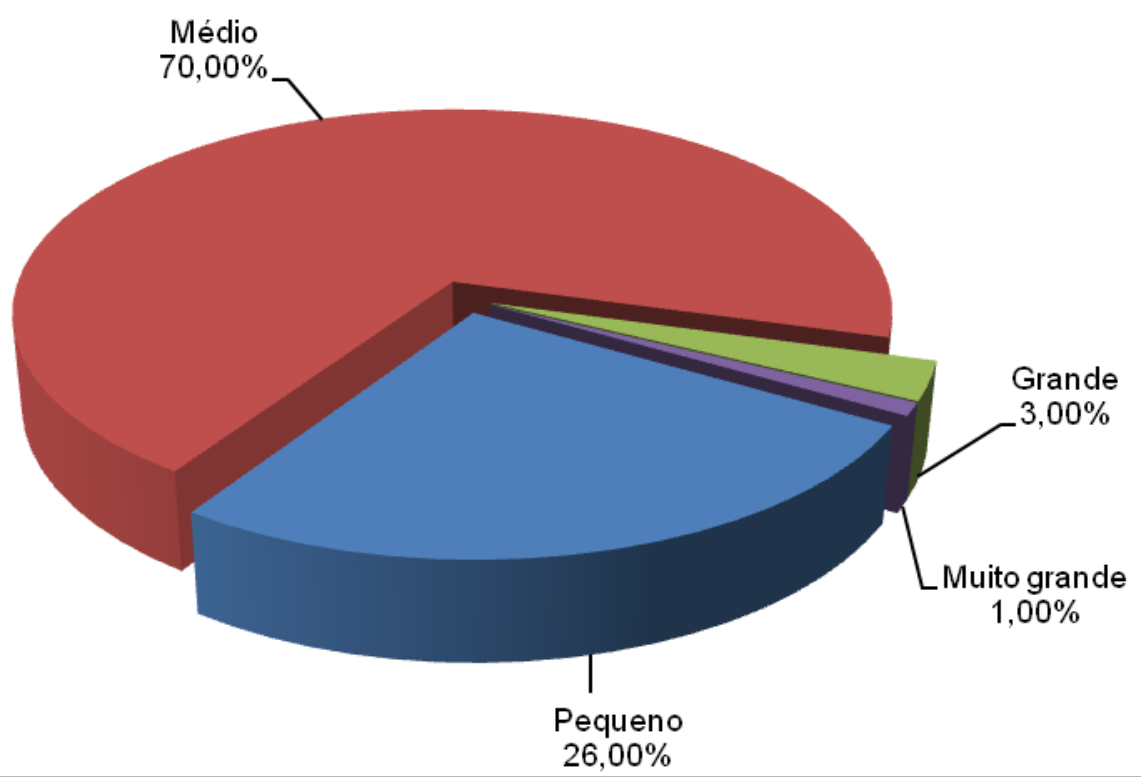

Gráfico 04: Índice comprimento x largura: categorias 
Fica evidente o aproveitamento da matéria-prima disponível nas proximidades do sítio; o arenito silicificado constitui quase a totalidade da coleção, assim como o suporte, que evidencia a predominância dos blocos disponíveis próximos ao sítio. A maioria das peças com córtex apresenta suporte de bloco. Os seixos e nódulos têm representação quase insignificante. Desse modo, do total de lascas, sobre a identificação do suporte temos 45,7 \% não identificado; 53,4\% bloco; 0,5\% nódulo; 0,2\% cristal e 0,2\% seixo.

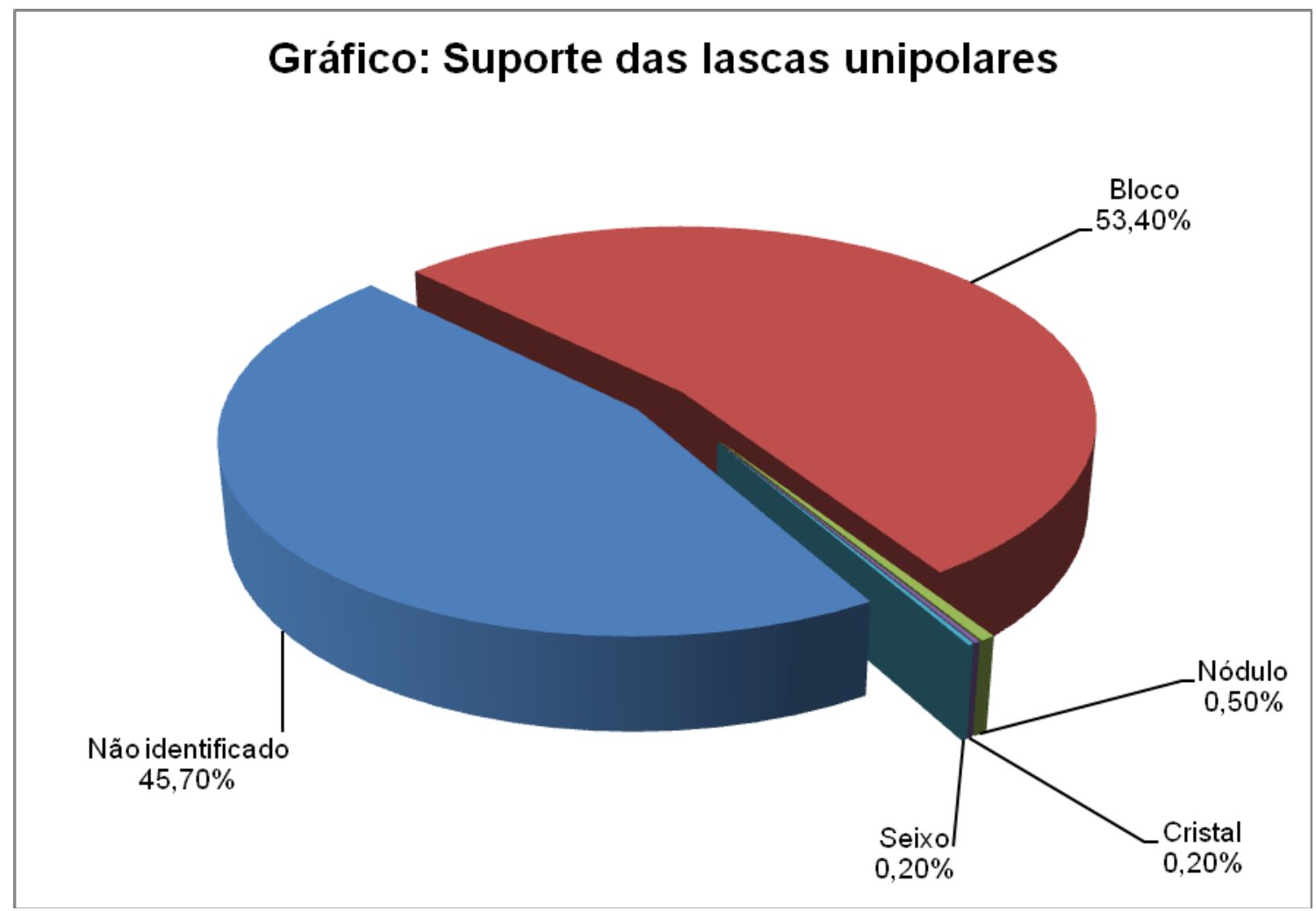

Gráfico 05: Suporte das Lascas Unipolares

Há a predominância de lascas sem córtex. Isso parece estar de acordo com o tipo de indústria que analisamos: considerando que temos na coleção núcleos de grandes dimensões. A exploração da matéria-prima é principalmente direcionada para suportes de grandes volumes. Os núcleos grandes dão a oportunidade de retirar grande quantidade de lascas sem córtex antes do esgotamento. Esse parece ser o fator responsável pela predominância de lascas sem córtex. Temos assim os núcleos com as medidas entre 75 mm para a altura; $102 \mathrm{~mm}$ para a largura e $70 \mathrm{~mm}$ para a espessura. 


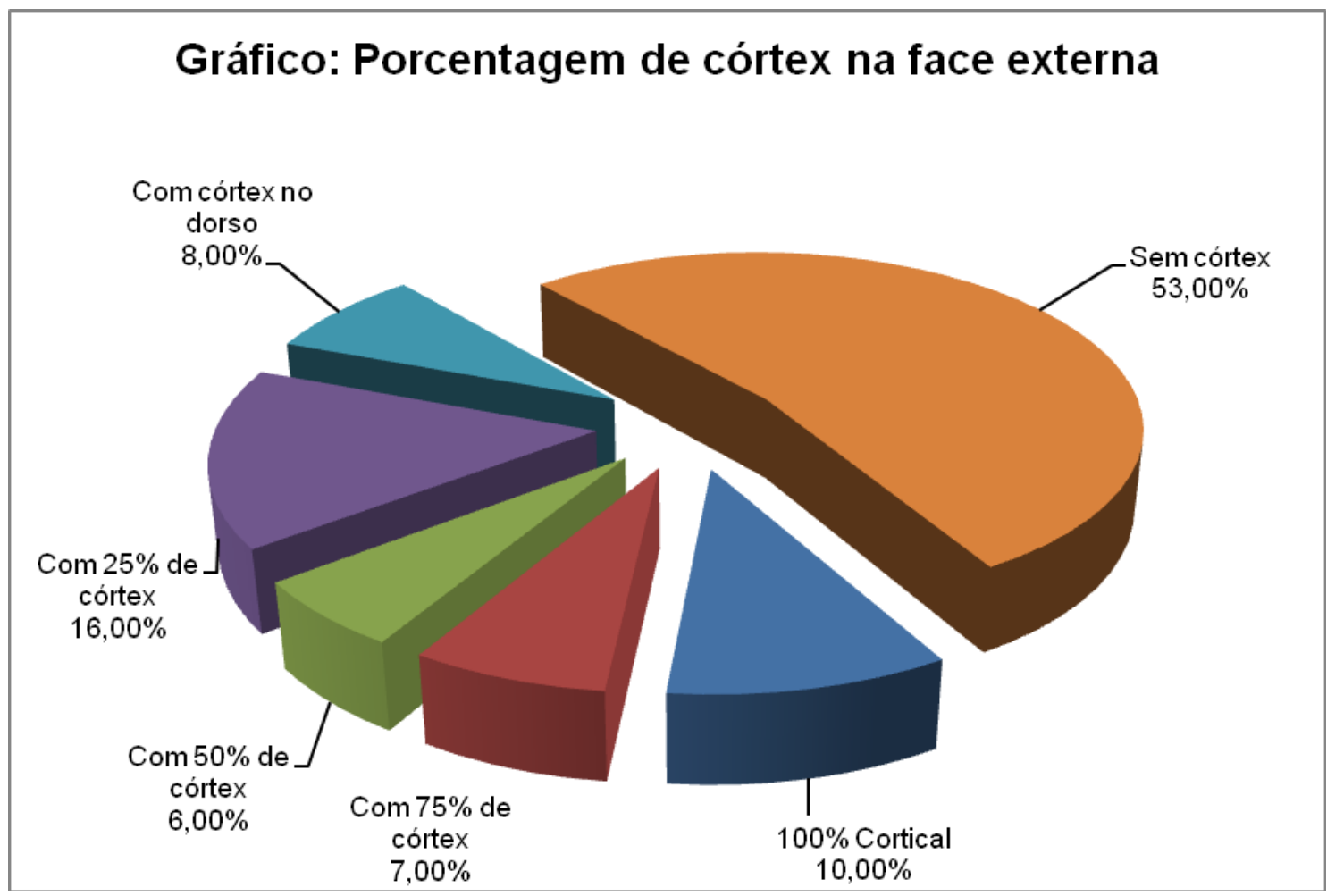

Gráfico 06: Porcentagem de Córtex na Face Externa

Observando a morfologia dos talões podemos notar uma predominância de talões lisos, indicando a ausência de cuidado com a preparação do plano de percussão dos núcleos. Se cruzarmos os dados dos talões com os planos de percussão dos núcleos, veremos que a amostragem confirma essa predominância. É também representativo o número de talões esmagados, isso parece ocorrer principalmente quando há lascamento bifacial. Nessa coleção há alguns instrumentos produzidos por essa técnica. 


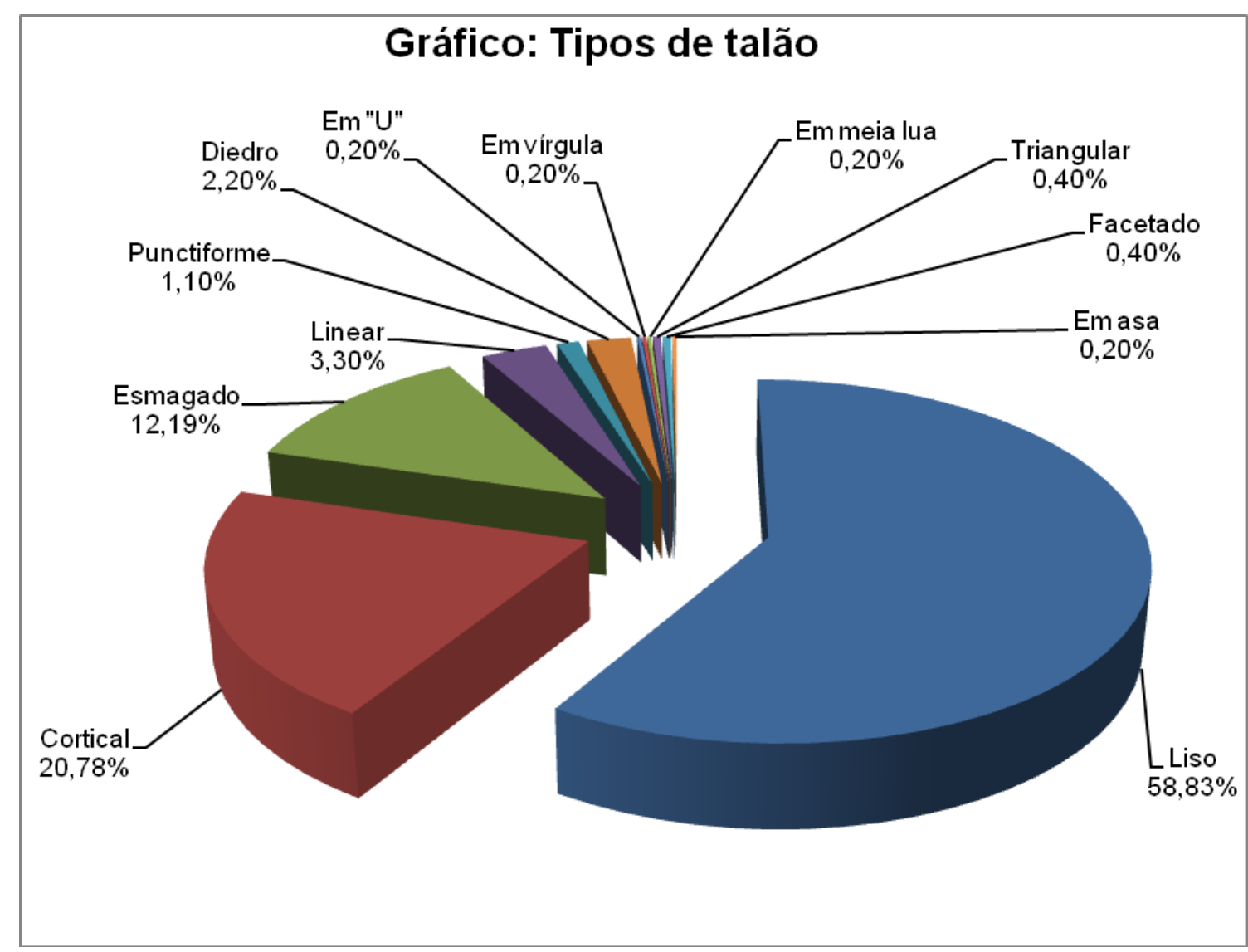

Gráfico 07: Tipos de Talão

A morfologia das lascas é bem variada. A comparação destes dados com a coleção de artefatos e núcleos nos leva a suposição de que não havia um planejamento muito padronizado do módulo do suporte a ser retocado, os núcleos não apresentam seqüências de lascamento organizadas, os artefatos não são uniformes e não há padronização morfológica das lascas retiradas. Ao que tudo indica, os suportes com dimensões adequadas e boa qualidade da matéria-prima eram aproveitados independente da forma. 


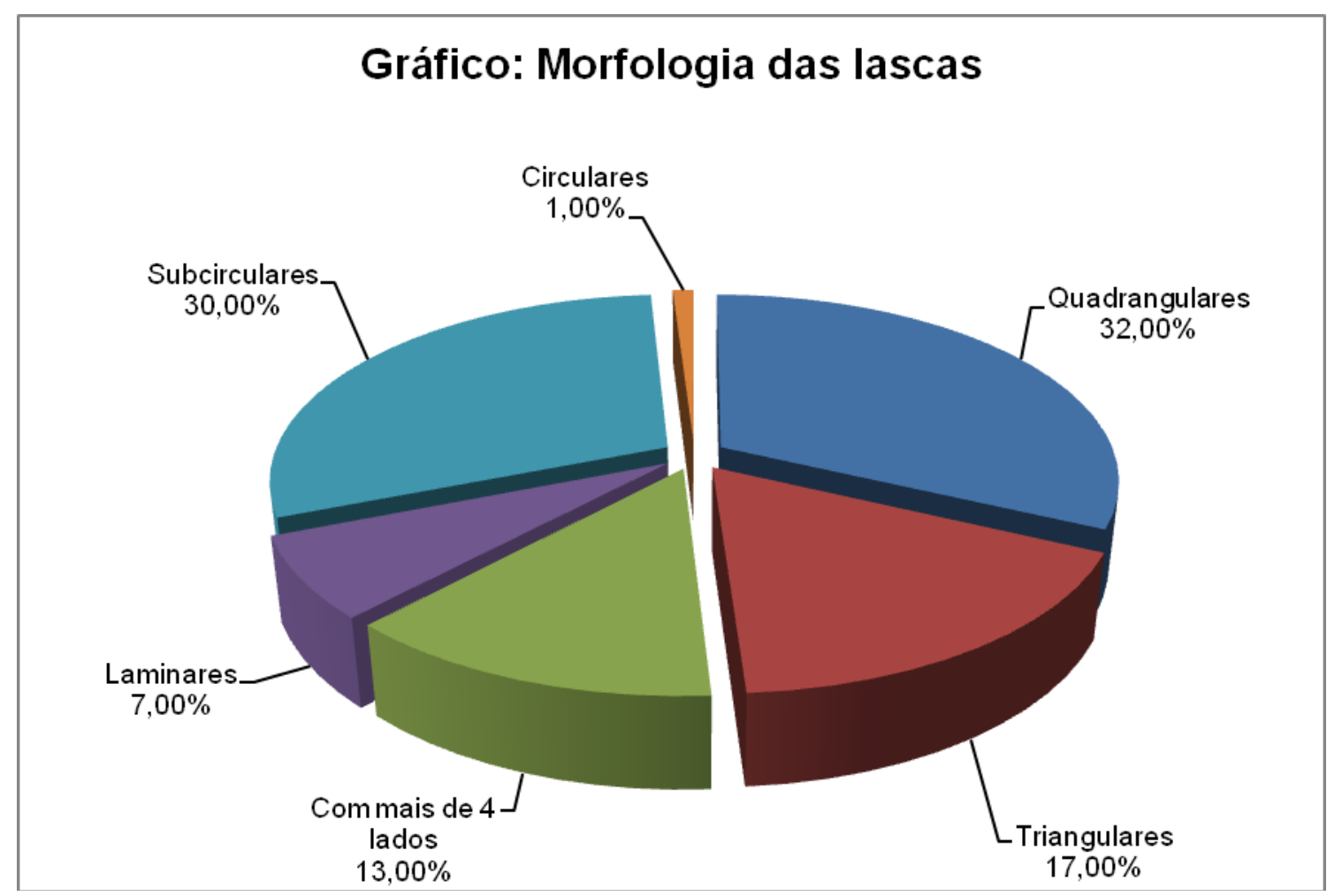

Gráfico 08: Morfologia das Lascas

Os acidentes de lascamento foram verificados em 18\% das lascas analisadas. Predomina a ocorrência de sirets, seguidas pelas lascas refletidas, ultrapassantes, com lingüeta e transbordantes. Os sirets são representados principalmente por peças com matéria-prima de qualidade inferior.

Quanto à cadeia operatória na confecção dos instrumentos, podemos perceber que seguiram na maior parte dos casos a seguinte seqüência: suporte selecionado > destacamento da lasca > retoques > abandono. Contando também com algumas variantes, em menor número, acidente de lascamento, fragmentação, formatação do artefato, reciclagem e marcas recentes ${ }^{19}$.

Dos 23 instrumentos coletados, 7 são plano-convexos, inteiros ou fragmentados, retocados unifacialmente, principalmente produzidos sobre lascas grandes. Em seguida há 4 lascas retocadas unifacialmente, 3 instrumentos retocados bifacialmente, 2 apresentando coche (reentrância), 2 fragmentos, sendo um de bloco e outro não identificado, com retoques unifaciais e 3 pré-formas de artefatos. A média das medidas está entre 67 mm para o comprimento; $51 \mathrm{~mm}$ para a largura e $19 \mathrm{~mm}$ para a espessura.

\footnotetext{
${ }^{19}$ Sinais de implementos agrícolas - marcas não arqueológicas.
} 
Os instrumentos do Sítio Dois Córregos, evidenciam, pelo conjunto de bordos ativos, uma média de quase 3 bordos ativos por peça. Essa estimativa aponta para o fato de se tratarem de instrumentos de múltiplas funcionalidades, ou utilizados (e reutilizados) para a mesma função em mais de um bordo ou em diversas partes do mesmo bordo.

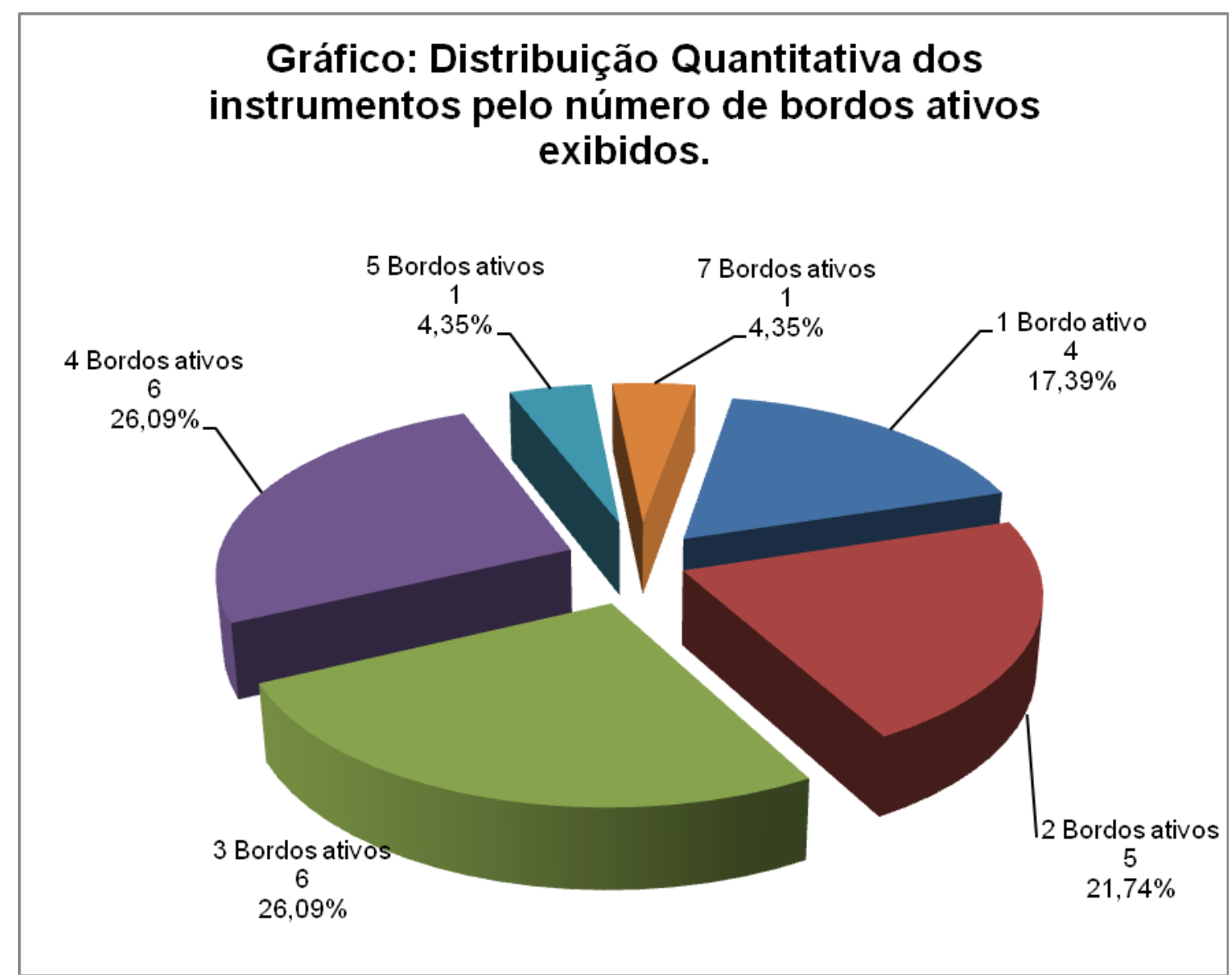

Gráfico 09: Distribuição Quantitativa dos Utensílios pelo Número de Bordos Ativos Exibido 


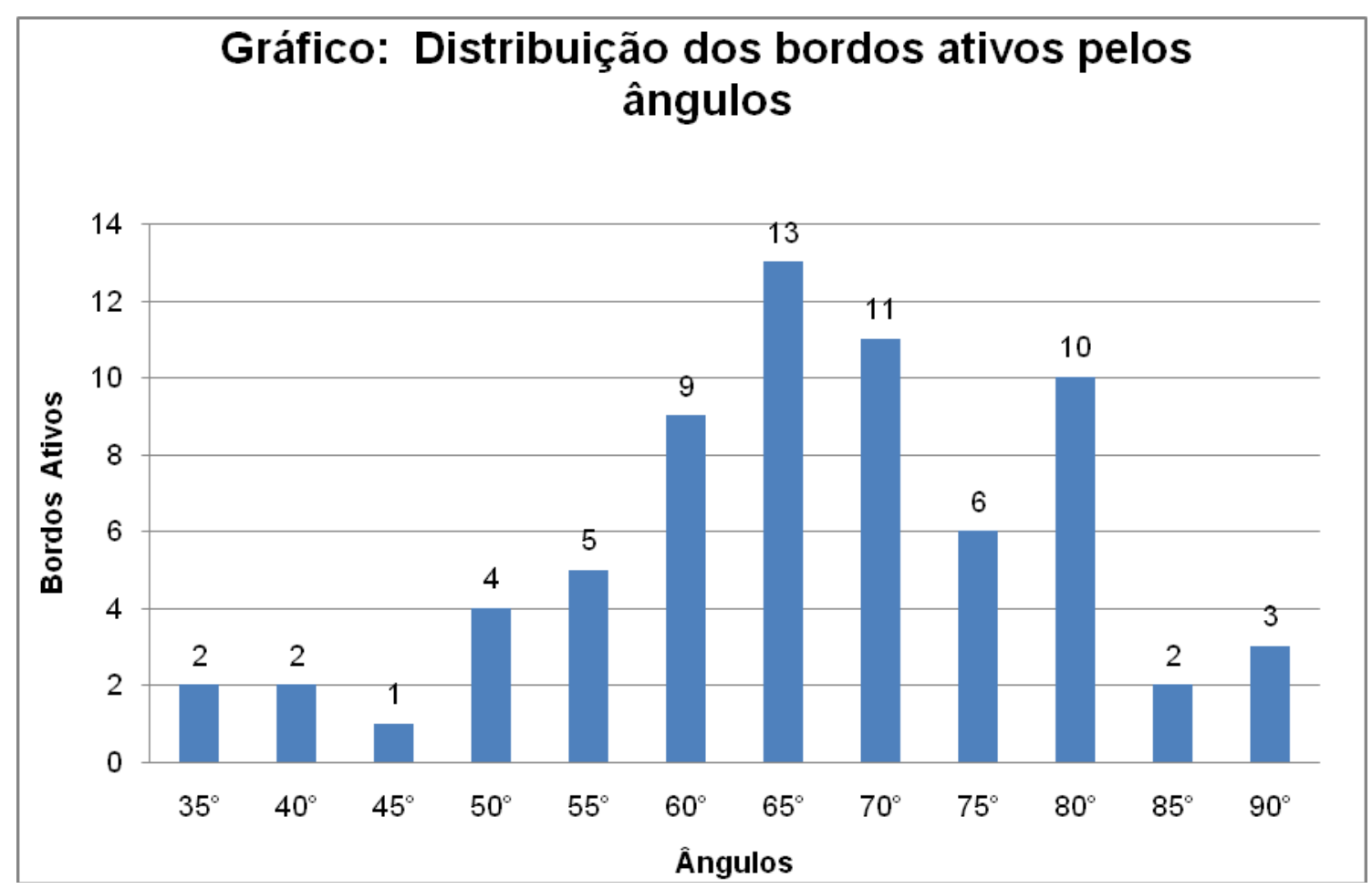

Gráfico 10: Distribuição dos Bordos Ativos pelos Ângulos

Podemos perceber ainda, pelo gráfico acima, que predominam os ângulos mais abertos (entre 60 e $90^{\circ}$ ), os quais correspondem a 50 dos 68 bordos ativos identificados, ou seja, 73,5\% dos bordos ativos. Esses são considerados ângulos mais favoráveis a atividades de raspagem. Já os ângulos mais fechados (entre 35 e 55²) incidem sobre apenas 18 bordos, correspondendo aos gumes mais favoráveis à função de corte (Scientia, 2005).

A descrição um pouco mais detalhada dos instrumentos do sítio Dois Córregos pode ser vista nas pranchas apresentadas a seguir. As peças aqui ilustradas foram selecionadas de modo a representar a totalidade da coleção ${ }^{20}$.

\footnotetext{
${ }^{20}$ Os desenhos dos instrumentos do Sítio Dois Córregos, aqui apresentados, foram feitos por Claide de Paula Moraes. De modo que o crédito das ilustrações pertence a ele (SCIENTIA, 2005).
} 

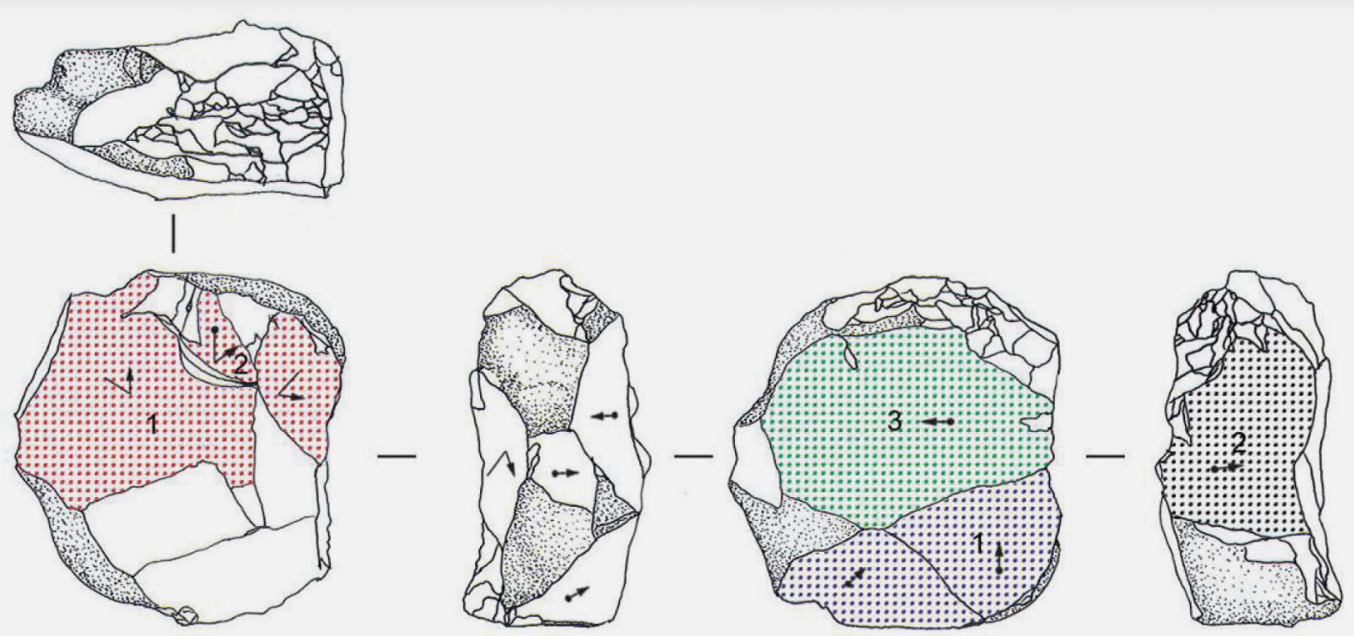

DC-395
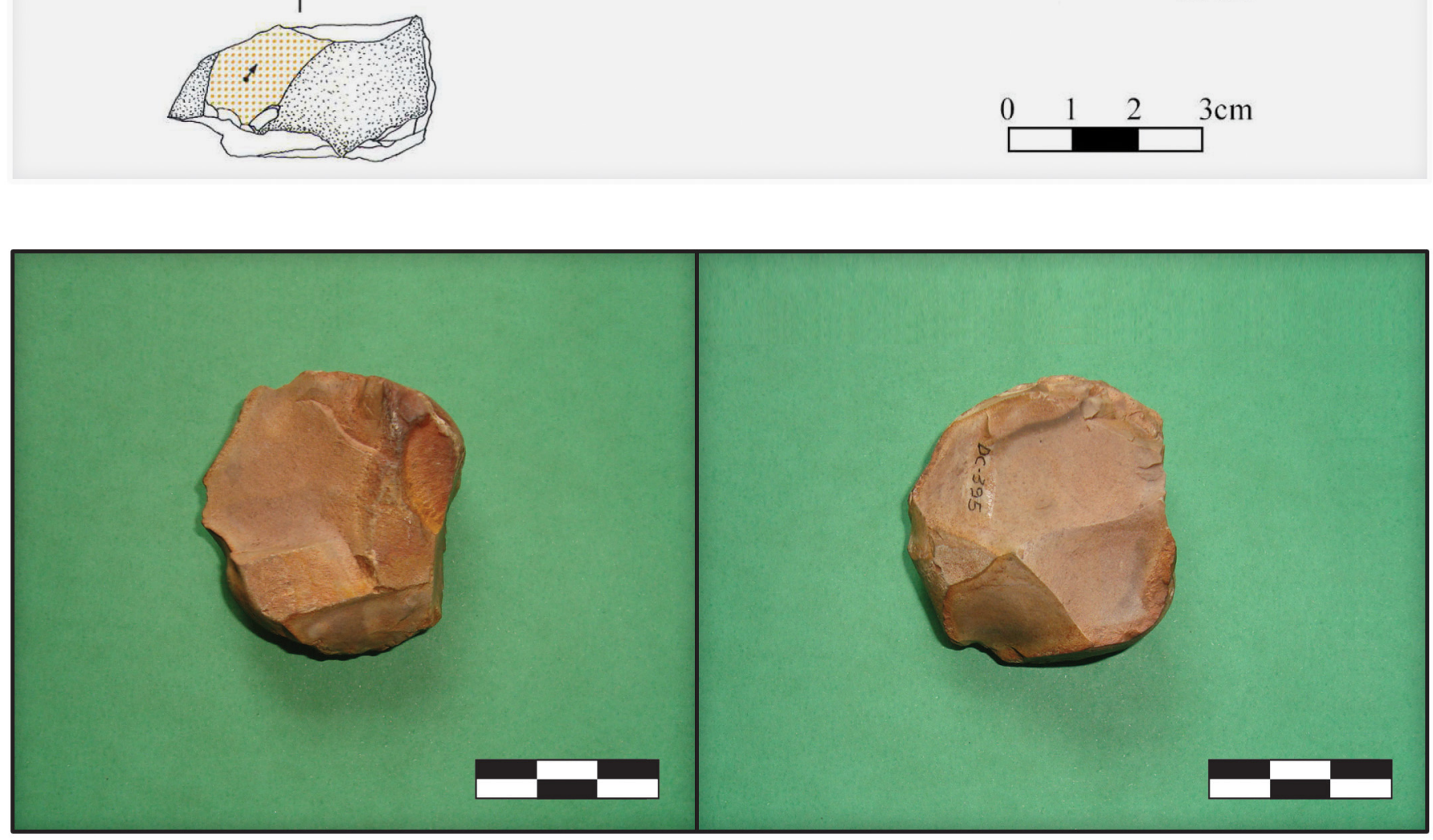

A peça 395 é um núcleo discoidal, sobre seixo de silexito, com marcas de ação térmica (uma coloração avermelhada em algumas partes) medindo $42 \mathrm{~mm}$ de altura, $38 \mathrm{~mm}$ de largura e $20 \mathrm{~mm}$ de espessura, com 40 gramas de peso e cerca de $25 \%$ da superfície cortical. A peça apresenta cinco planos de percussão englobantes. O plano principal é cortical com três negativos refletidos representados na primeira face. O maior negativo é de uma lasca subcircular, provavelmente com $26 \mathrm{~mm}$ de comprimento e $32 \mathrm{~mm}$ de largura. Não é possível identificar as dimensões do talão, pois a superfície deste negativo foi utilizada como plataforma para a retirada de outra lasca (na coleção existem 15 peças semelhantes).

Sobrepondo o negativo descrito anteriormente, tem-se a retirada de uma lasca quadrangular, provavelmente com $10 \mathrm{~mm}$ de comprimento e $13 \mathrm{~mm}$ de largura, com talão cortical medindo $9 \mathrm{~mm}$ de comprimento e ângulo com a face interna $100^{\circ}$. Esta lasca provavelmente não tinha nervuras na face externa (na coleção existe 1 peça semelhante). O outro negativo está sobreposto pelo negativo do quinto plano, não sendo possível identificar sua forma e dimensões. Esta provavelmente era uma lasca com a face externa cortical. $\mathrm{O}$ segundo plano de percussão apresenta dois negativos representados na segunda face, sendo o maior o negativo de uma lasca com mais de quatro lados, provavelmente com $18 \mathrm{~mm}$ de comprimento e $22 \mathrm{~mm}$ de largura, com talão liso medindo $8 \mathrm{~mm}$ de comprimento e ângulo com a face interna de $130^{\circ}$. Esta lasca provavelmente tinha a face externa cortical. O outro negativo deste plano é de uma lasca subcircular, provavelmente com $8 \mathrm{~mm}$ de comprimento e $11 \mathrm{~mm}$ de largura, com talão liso medindo $5 \mathrm{~mm}$ de comprimento e ângulo com a face interna de $110^{\circ}$ (na coleção existe 1 peça semelhante). $O$ terceiro plano possui um negativo de uma lasca subcircular, provavelmente com $37 \mathrm{~mm}$ de comprimento e $25 \mathrm{~mm}$ de largura, com talão liso medindo $7 \mathrm{~mm}$ de comprimento e ângulo com a face interna de $110^{\circ}$. Esta lasca provavelmente tinha uma nervura na face externa, com uma parte da superfície cortical. O quarto plano possui um negativo de lasca com talão cortical medindo $9 \mathrm{~mm}$ de comprimento e ângulo com a face interna de $90^{\circ}$. Não é possível identificar sua morfologia e dimensões devido à sobreposição pelo negativo do terceiro plano de percussão (na coleção existem 5 peças semelhantes).

Finalmente, tem-se o quinto plano de percussão com o negativo de uma lasca quadrangular medindo $19 \mathrm{~mm}$ de comprimento e $26 \mathrm{~mm}$ de largura, com talão liso medindo $11 \mathrm{~mm}$ de comprimento e ângulo com a face interna de $100^{\circ}$. Esta lasca provavelmente tinha a face externa totalmente cortical.

$\mathrm{Na}$ sexta face representada há várias pequenas fraturas de esmagamento de um provável uso desta peça como percutor. O primeiro e quarto plano de percussão estão esgotados (Scientia, 2005).

MUSEU DE ARQUEOLOGIA E ETNOLOGIA DA UNIVERSIDADE DE SÃO PAULO SÍTIOS LÍTICOS NO INTERIOR PAULISTA: UM ENFOQUE REGIONAL
Sítio Dois Córregos

Dois Córregos, SP 

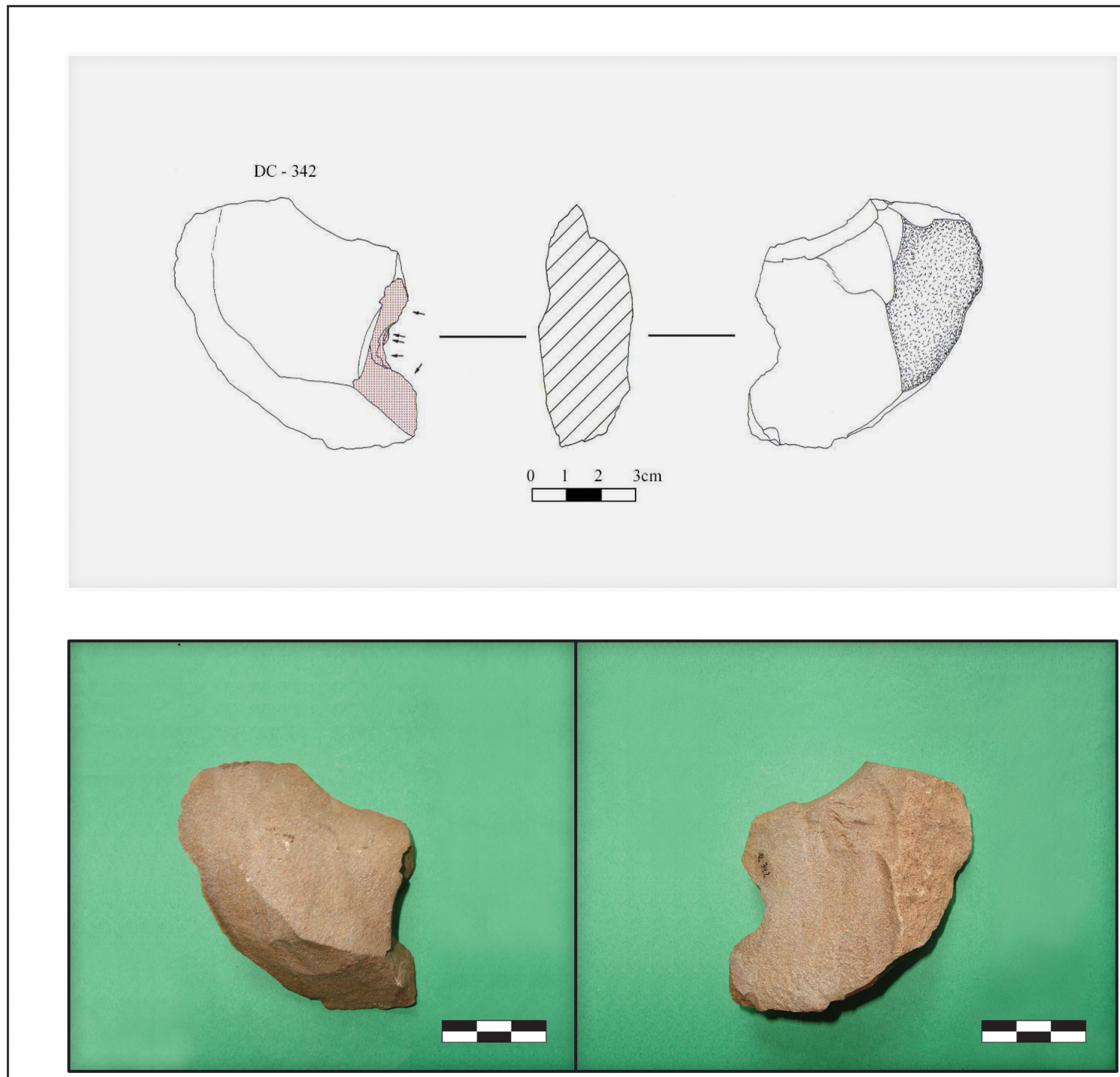

A peça 342 é um artefato de arenito sobre fragmento de lasca destacada de bloco. A orientação do artefato é arbitrária, ficando os retoques no bordo direito, porção mesial, sendo uma seqüência com 5 negativos de retoques escalariformes, curtos e abruptos, formando uma reentrância do tipo coche. $O$ peso da peça é de 100 gramas. 

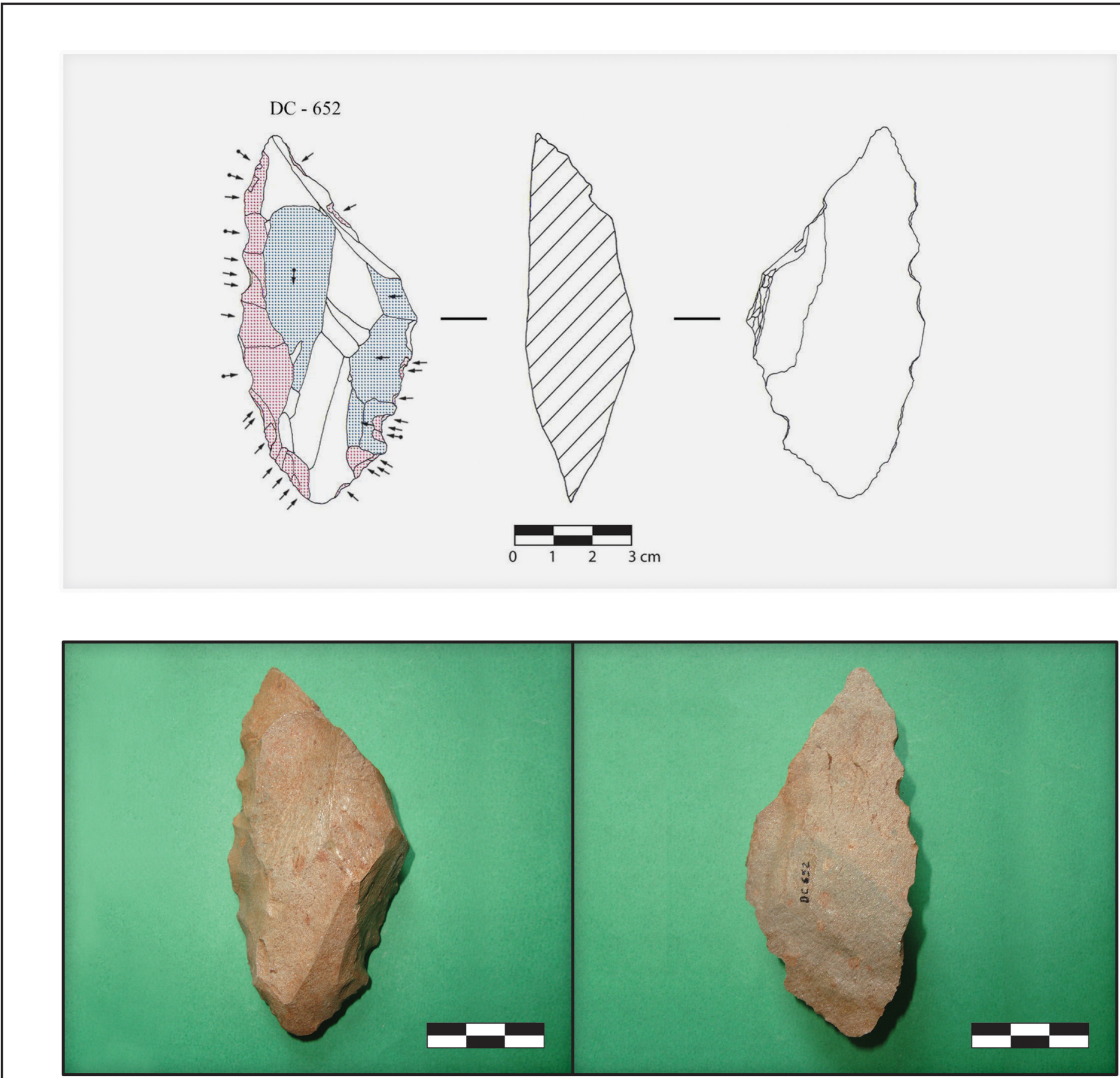

A peça 652 é um artefato plano-convexo fragmentado, produzido sobre lasca de arenito, não é possível identificar o suporte de produção da lasca devido à ausência de córtex. $O$ talão e o bulbo foram retirados durante o processo de formatação do artefato, por este motivo a orientação da peça é arbitrária, ficando a quebra na porção distal e a face com os negativos de retoques para cima. No bordo esquerdo tem-se uma seqüência com 7 negativos de retoques paralelos, longos, sendo 6 abruptos e 1 muito oblíquo. Posteriormente, há outra seqüência com 9 negativos de retoques no mesmo bordo sobrepondo os anteriores, são negativos curtos, sendo 5 abruptos e 4 verticais. Como pode ser visto na figura, não se tem todo o bordo da peça devido a uma quebra na porção distal. No bordo direito há 3 negativos de retiradas de formatação do artefato, sobrepostas por uma seqüência com 9 negativos de retoques subparalelos, curtos e abruptos. Este bordo também está fragmentado pela quebra na porção distal do artefato. Após a fragmentação do artefato podemos notar uma tentativa de readequação do módulo volumétrico da peça. Há duas retiradas de formatação posteriores à quebra e dois negativos de retoques curtos e abruptos. Na segunda face representada podemos observar uma seqüência de pequenos golpes que provocaram um abrasamento do gume na porção mesial do artefato. $\mathrm{O}$ que se tem ao final é um artefato plano-convexo com os gumes laterais bem regularizados, os dois bordos se convergem em uma superfície não muito pontiaguda, mas cortante, na porção extremo-distal e mesmo após a fragmentação tem-se a produção de um bico na porção extremo distal. O peso da peça é de 90 gramas. 

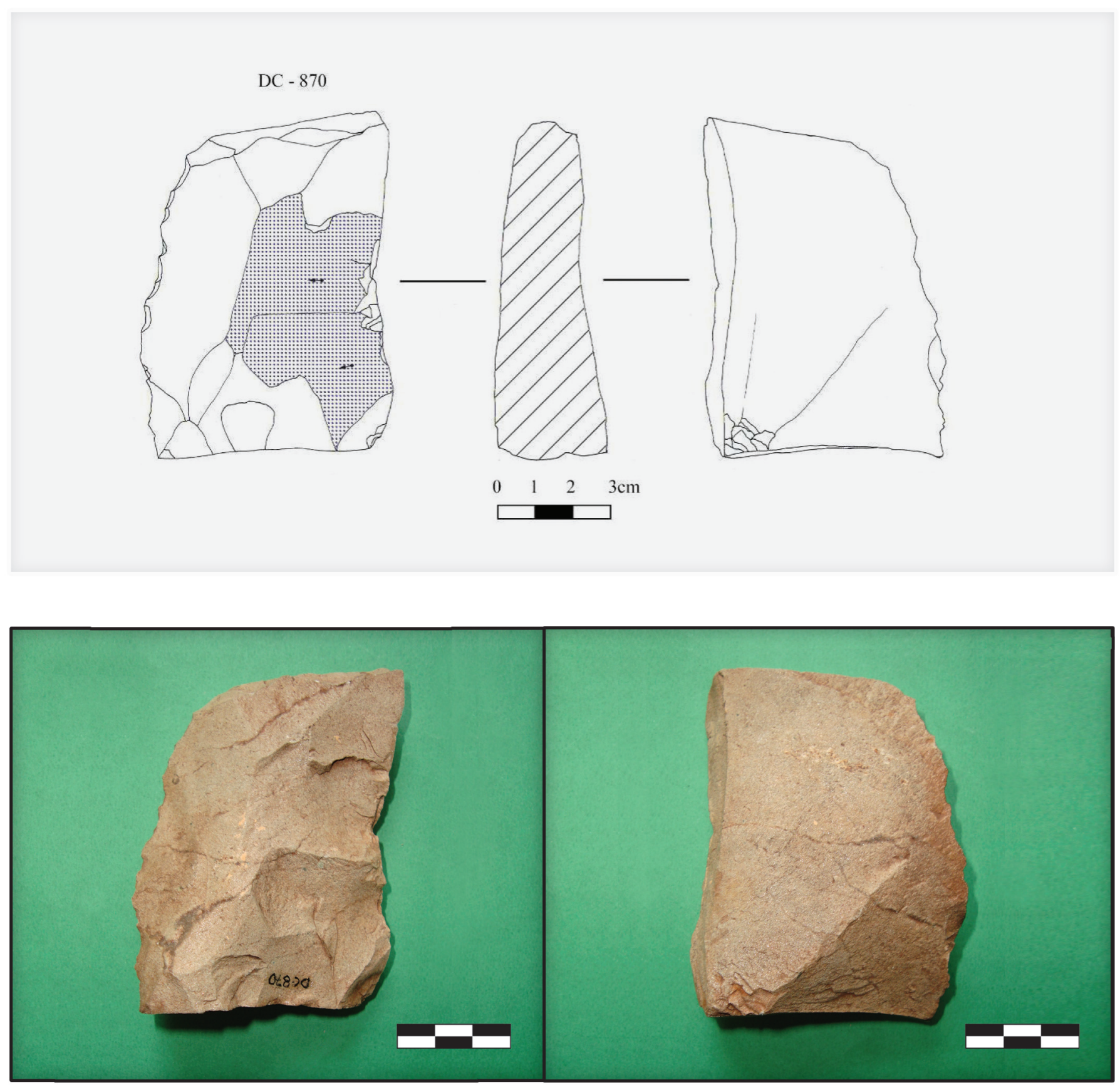

A peça 870 é uma pré-forma de artefato sobre lasca de arenito fragmentada em siret, não foi possível identificar o suporte de produção devido à ausência de córtex. A peça possui talão liso, fragmentado no comprimento e com $16 \mathrm{~mm}$ de largura. $\mathrm{O}$ ângulo do talão com a face interna é $100^{\circ}$. As dimensões da peça são: $88 \mathrm{~mm}$ de comprimento, $64 \mathrm{~mm}$ de largura e $24 \mathrm{~mm}$ de espessura. $O$ peso da peça é de 170 gramas. Posterior ao destacamento da lasca podemos observar um trabalho que visou diminuir a massa do suporte através da retirada de duas lascas no dorso formado pelo plano dequebra do siret, são dois negativos de lascas invadentes. Na face externa, porção proximal,podemos observar 2 negativos de lascas retiradas para diminuir o volume do siret em sua espessura, são dois negativos curtos. 

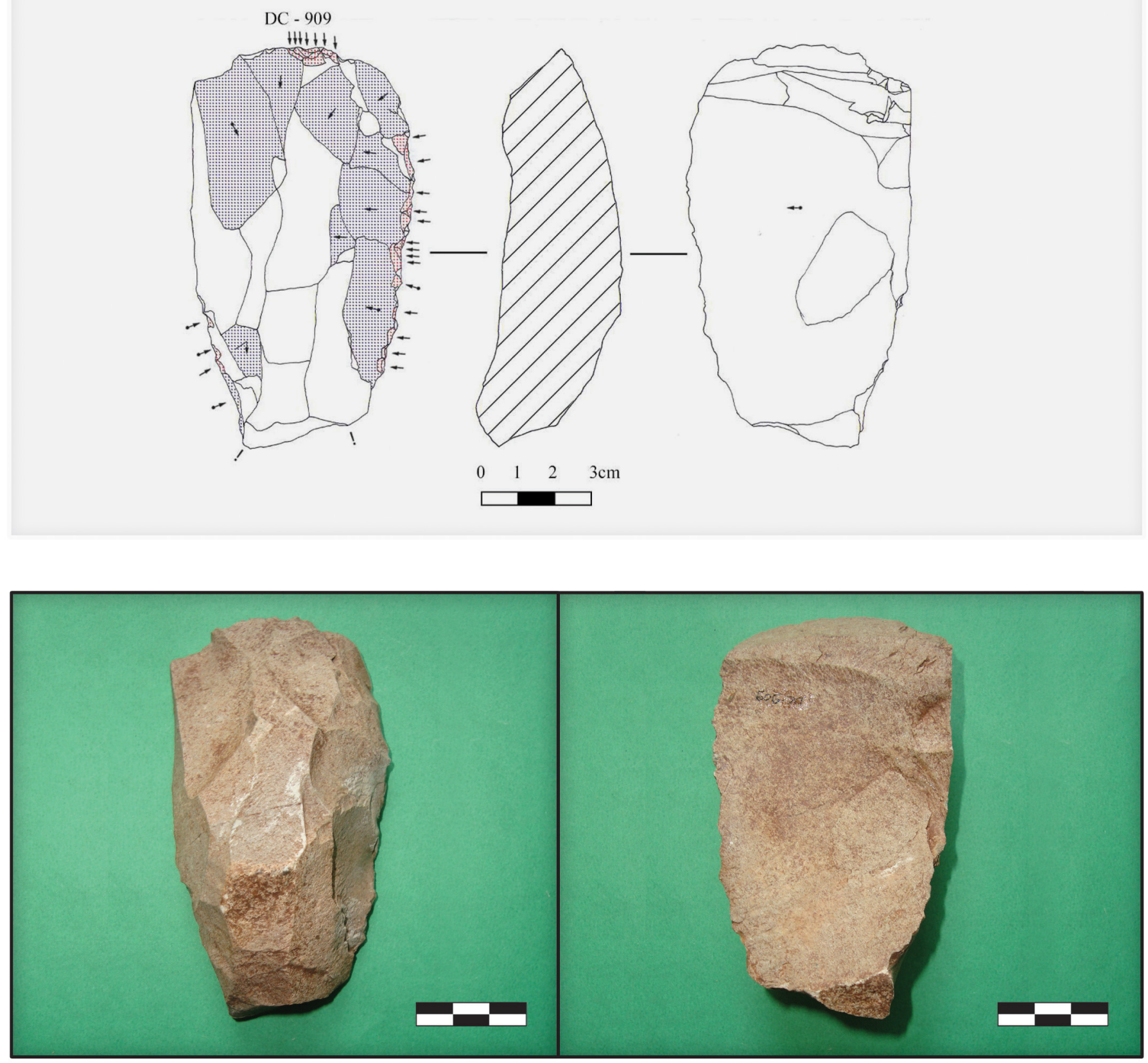

A peça 909 é um artefato de arenito retocado. Não foi possível identificar o suporte de produção devido à ausência de córtex, portanto sua orientação é arbitrária, ficando a face com os negativos de formatação e retoques votados para o observador e o bordo com o maior número de negativos de retoques à direita. Os 10 negativos de retiradas de formatação estão convergindo da periferia para o centro da peça. No bordo direito há uma seqüência com 12 negativos de retoques paralelos, não contínuos, curtos e abruptos. No bordo esquerdo há 3 negativos de retoques curtos e abruptos. Na porção extremo distal há uma seqüência com 7 negativos de retoques escalariformes, curtos e abruptos. O resultado foi a produção de um gume retilíneo, bem regularizado no bordo direito e um gume levemente convexo na porção extremo distal. No bordo esquerdo as intervenções perecem ter objetivado uma melhor preensão do artefato. $O$ peso da peça é de 230 gramas. 

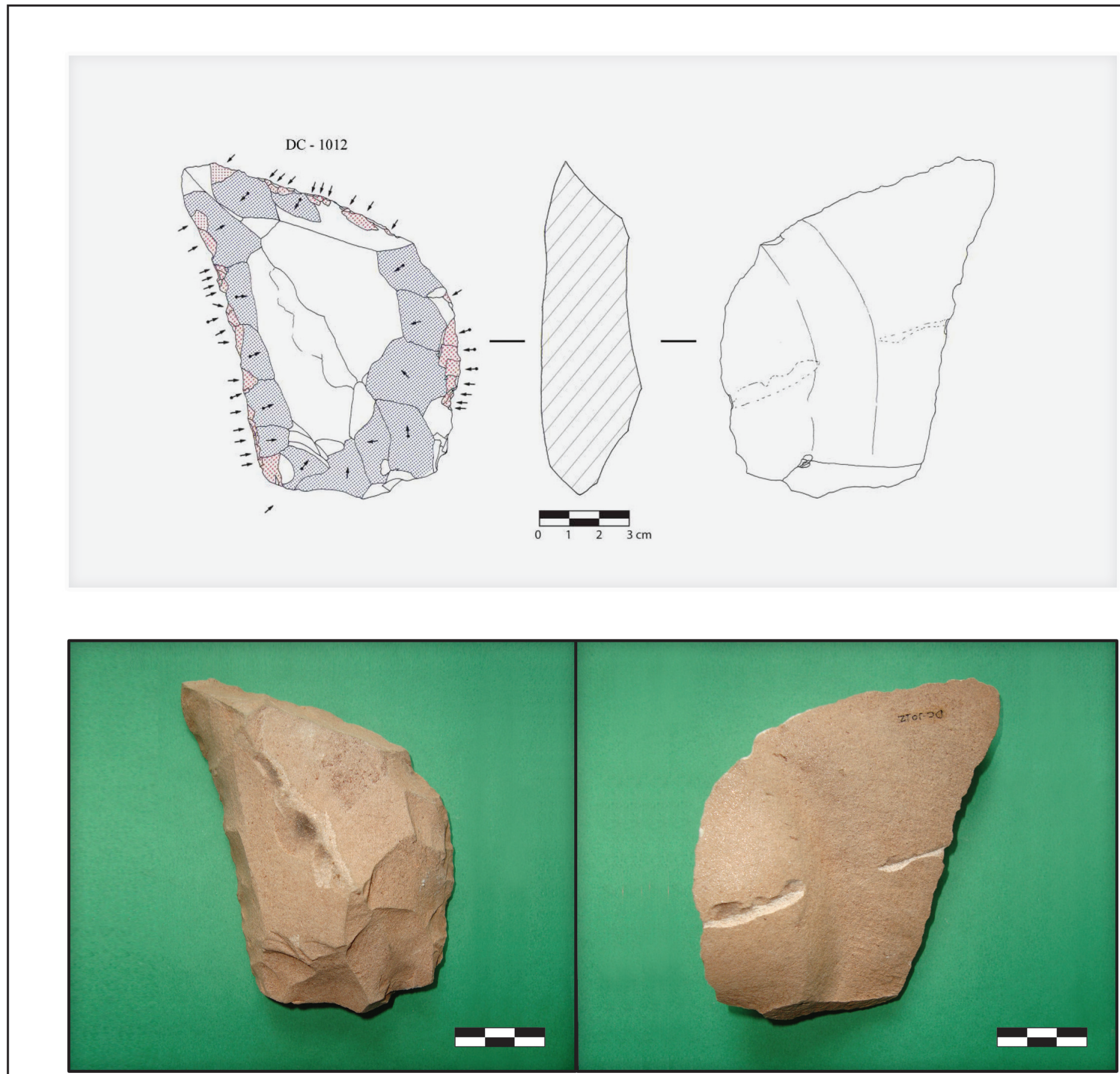

A peça 1012 é um artefato produzido sobre lasca de arenito, não foi possível identificar o suporte de produção da lasca devido à ausência de córtex. O talão e a parte proximal do bulbo foram retirados durante o processo de formatação do artefato, por este motivo a orientação da peça é arbitrária, ficando em primeiro plano a face com os negativos de retoques e o bico produzido pelos retoques na porção extremo-distal esquerda. Na porção extremo-proximal há 4 negativos de retiradas de formatação do suporte. No bordo esquerdo há 6 negativos de retiradas de formatação do suporte sobrepostos por uma seqüência com 17 negativos de retoques subparalelos, não contínuos, curtos e abruptos. No bordo direito há 5 negativos de retiradas de formatação do suporte sobrepostos por uma seqüência com 7 negativos de retoques subparalelos, variando entre curtos e muito oblíquos. Na porção distal do bordo direito há outra seqüência com 10 negativos de retoques paralelos, não contínuos, curtos e abruptos.

O resultado final é um artefato com diversificadas possibilidades de utilização possuindo um gume levemente côncavo no bordo esquerdo, um gume convexo no bordo direito e um bico na porção extremo-distal esquerda. O peso da peça é de 280 gramas. Uma da melhores formas de preensão do artefato parece ser o apoio da mão direita no bordo esquerdo com o bico na direção do punho. Existem marcas recentes em ambas as faces do artefato, provavelmente deixadas por algum implemento agrícola. 


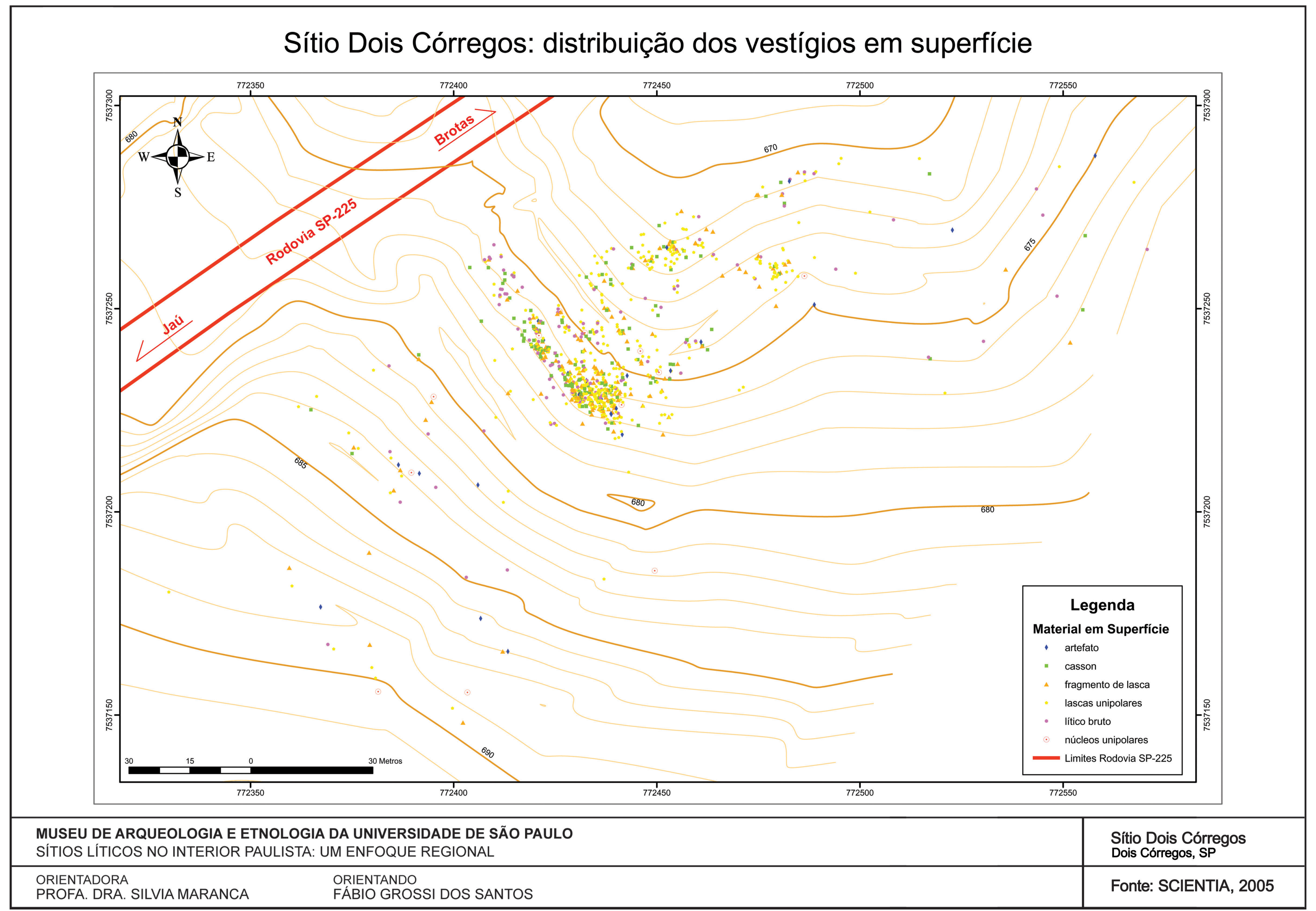




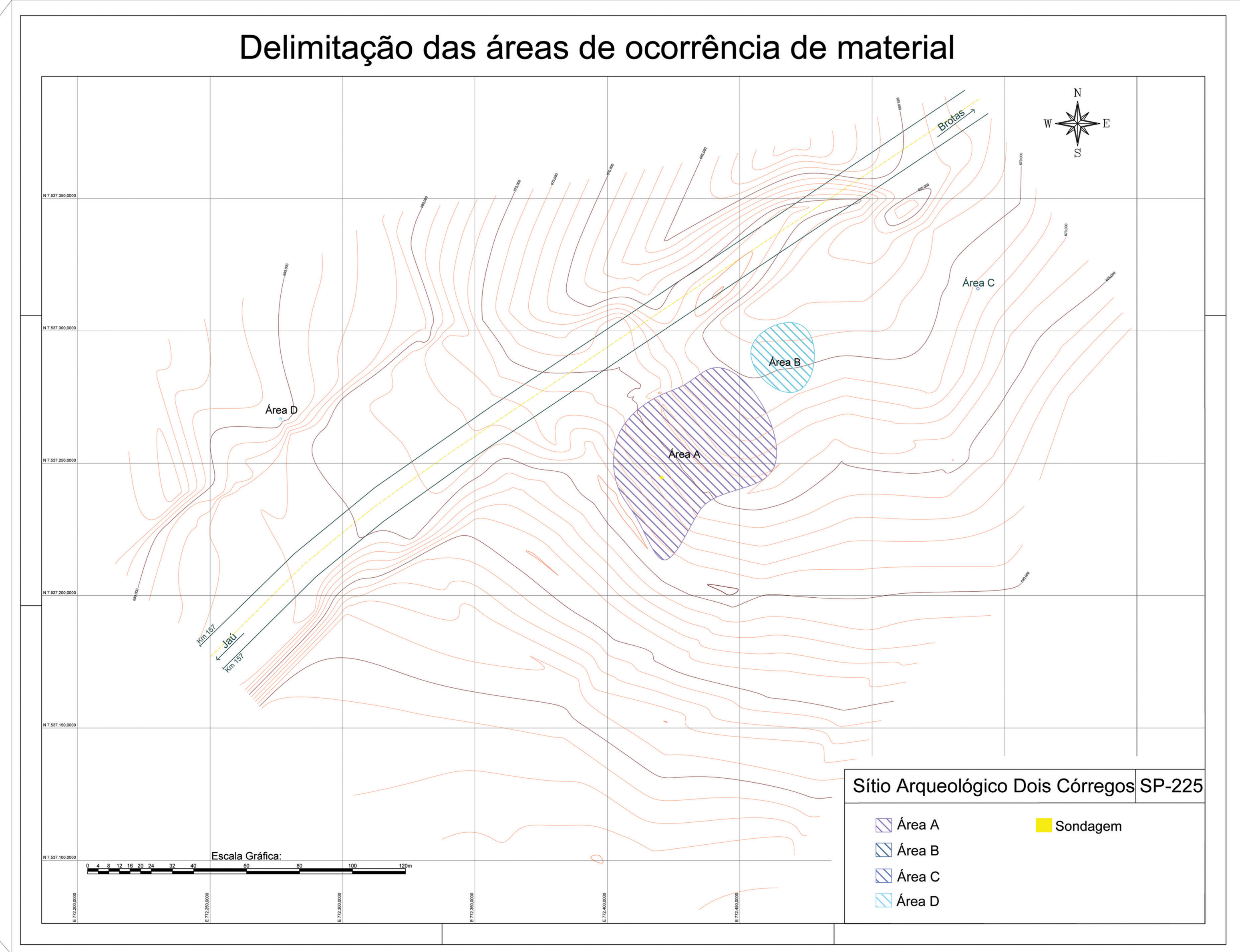

MUSEU DE ARQUEOLOGIA E ETNOLOGIA DA UNIVERSIDADE DE SÃO PAULO

Sítio Dois Córregos SITIOS LITICOS NO INTERIOR PAULISTA: UM ENFOQUE REGIONAL

Dois Córregos, SP 


\section{IV.2.1) Estratigrafia}

Na única unidade de escavação realizada no Sítio Dois Córregos, foi observado um único estrato, até os $40 \mathrm{~cm}$ de profundidade, limite da localização de material arqueológico. O solo se manteve homogêneo, do tipo Latossolo Vermelho-Escuro álico/Latossolo Roxo (Latossolos Vermelhos - LV).

\section{IV.2.2) Análise de dados}

É interessante notar que tanto a área quanto a implantação do sítio correspondem ao que se conhece sobre os sítios arqueológicos de caçadores-coletores registrados em vários locais da Bacia do Médio Rio Tietê (Caldarelli, 2001-2002).

Sobre a aquisição da matéria-prima, parece claro que a implantação do sítio está diretamente relacionada à facilidade de obtenção dos recursos necessários para o lascamento.

Geologicamente, a região exibe uma variabilidade litológica que compreende, tanto rochas sedimentares, quanto ígneas e metamórficas. O sítio está implantado muito próximo à Cuesta, onde principalmente o basalto ocorre em abundância. Associado à formação basáltica da região ocorrem veios de arenito silicificado, o que apresenta a principal matéria-prima explorada pelos ocupantes do sítio Dois Córregos. Quanto à forma de ocorrência, o basalto compõe o maciço de formação da serra. Em uma observação do entorno do sítio foi constatada a presença de blocos destacados do maciço, principalmente basalto, e em menor quantidade, mas também abundantes, blocos de arenito silicificado intertrappiano, comum na formação Serra Geral. Há um pequeno curso d’água próximo ao sítio onde é grande a oferta de blocos de arenito e basalto. Apesar de haver material lascado em basalto na coleção recolhida, esta não é uma matéria-prima boa para o lascamento, existe a possibilidade de retirada de lascas grandes, mais retoques seriam praticamente impossíveis no basalto local.

Conforme pode ser observado na disposição do sítio, o material foi transportado para áreas específicas do sítio e posteriormente processado. A dificuldade maior parece ter sido a obtenção dos artefatos brutos (percutores), pois não há a ocorrência de seixos nas proximidades. Alguns seixos de quartzito e silexito, provavelmente foram obtidos em 
localidades mais distantes. Uma das alternativas adotadas para contornar a dificuldade de obtenção de percutores parece ter sido a produção destes artefatos sobre suportes lascados.

Uma possível fonte deste artefato, nesse caso, poderia ter sido o sítio lítico Brotas, onde há a ocorrência de seixos de silexito, arenito e quartzito no leito do rio Jacaré-Pepira, e está a apenas alguns quilômetros de distância do Sítio Dois Córregos.

Quanto à função presumida dos artefatos, os ângulos dos possíveis bordos ativos nos permitem algumas inferências. Como foi mencionado, predominam no Sítio Dois Córregos os ângulos mais abertos (entre 60 e 90) que são mais favoráveis a atividades de raspagem.

Não foram identificadas extremidades em pontas, indicativas da função de perfurar. Embora alguns artefatos sobre blocos pudessem ter sido usados para percussão, exceto em um deles, não foram identificadas marcas dessa função em suas superfícies.

A ausência de instrumentos para bater (usados em construção de cabanas, por exemplo) e de instrumentos perfurantes (usados, por exemplo, na confecção de adornos como colares e braceletes, ou ainda na confecção de vestimentas) e a presença de instrumentos para raspagem e corte indicariam um acampamento de atividades restritas, provavelmente voltado ao processamento da caça, para o qual os artefatos necessários eram produzidos localmente. É altamente provável que fosse um acampamento de estação seca, pois nada aponta para a construção de abrigos das chuvas. Aldeias em geral apresentam maior diversidade de instrumentos, correspondentes à pluralidade de funções que a vida doméstica exige, durante um período de tempo prolongado.

Quanto à análise espacial, temos o sítio implantado em uma área que foi impactada pela construção da rodovia SP-225 e por muitos anos de agricultura de cana-de-açúcar. Mesmo assim, foi possível identificar áreas de atividades, que apontam para uma organização dos vestígios no espaço do sítio.

A concentração de núcleos está associada à área com maior concentração de refugos tais como, lascas, fragmentos de lascas, cassons e fragmentos de lítico bruto. Isso parece indicar uma área para onde a matéria-prima foi transportada e posteriormente trabalhada. A distribuição dos artefatos já ocupa uma área maior, dando a impressão que nem todos eles foram deixados no local do lascamento. Esse fato corrobora a interpretação do sítio como um acampamento, de duração não constatada, no qual as atividades de lascamento da pedra 
desempenham papel importante, conforme mencionado acima, assim como as atividades de processamento de caça.

Nas análises em laboratório, chamou à atenção a grande quantidade de material com marcas de ação térmica. Contudo, no estudo de distribuição dos vestígios, para verificar se havia uma área específica onde o material estaria sendo tratado termicamente, percebeu-se que isso não ocorreu. A distribuição do material com ou sem ação térmica é homogênea por toda a área do sítio. A hipótese mais provável é que seja resultado de queimadas posteriores ao processo de formação do sítio, e não de tratamento térmico, enquanto técnica de lascamento.

Ao cruzar os dados da análise tecnológica dos vestígios constatou-se que a indústria lítica do sítio Dois Córregos era baseada principalmente na produção de lascas grandes que posteriormente foram transformadas em artefatos. Quase a totalidade do material foi produzida em arenito silicificado, matéria-prima abundante nas proximidades do sítio. Uma pequena quantidade de material em sílex também foi observada.

A dificuldade maior nesse sítio parece ter sido a obtenção de percutores, os seixos só são encontrados em áreas mais distantes. Uma saída encontrada parece ter sido a utilização de refugos de lascamento como percutores (Scientia, 2005).

\section{IV.3) Sítio Boa Esperança II (BES II)}

Dentre os três sítios estudados, o BES II é o que apresenta maior riqueza de informações, seja pela quantidade de material arqueológico no plano horizontal e vertical o que mostra uma maior área ocupada -, quanto por sua maior variedade e estado de conservação.

Na primeira intervenção, realizada em 2003, foram coletadas 1.352 peças no sítio coleta a qual se baseia este presente trabalho -, sendo 218 em superfície e 1134 em subsuperfície.

As características do material coletado na sondagem são as mesmas do material de superfície. Foram coletadas 627 lascas unipolares, 104 núcleos unipolares, 1 lasca bipolar, 1 núcleo bipolar, 37 instrumentos de gume retocado, 02 instrumentos de gume bruto, 1 
instrumento passivo, 101 percutores, 271 detritos de lascamento (casson), 155 fragmentos de lasca, 33 peças de lítico bruto e 19 estilhas.

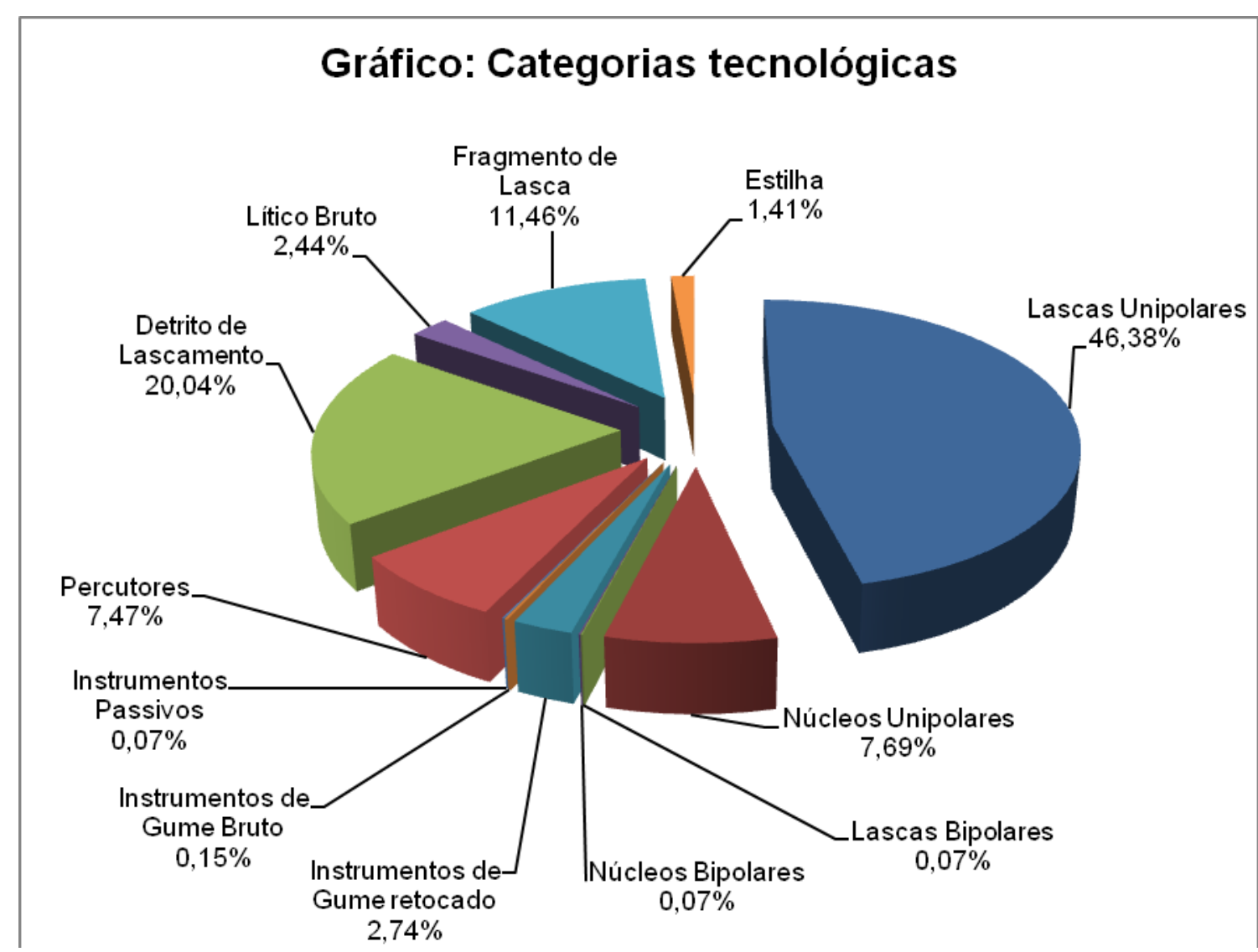

Gráfico 11: Categorias Tecnológicas

Como demonstra o gráfico abaixo, a grande maioria do material coletado é de sílex (792 peças - 58,58\%). Na seqüência tem-se o Arenito Silicificado (357 peças - 26,4\%); o quartzo (172 peças - 12,72\%); o arenito (25 peças - 1,85\%); e por fim, o conglomerado (06 peças $-0,44 \%)$. 


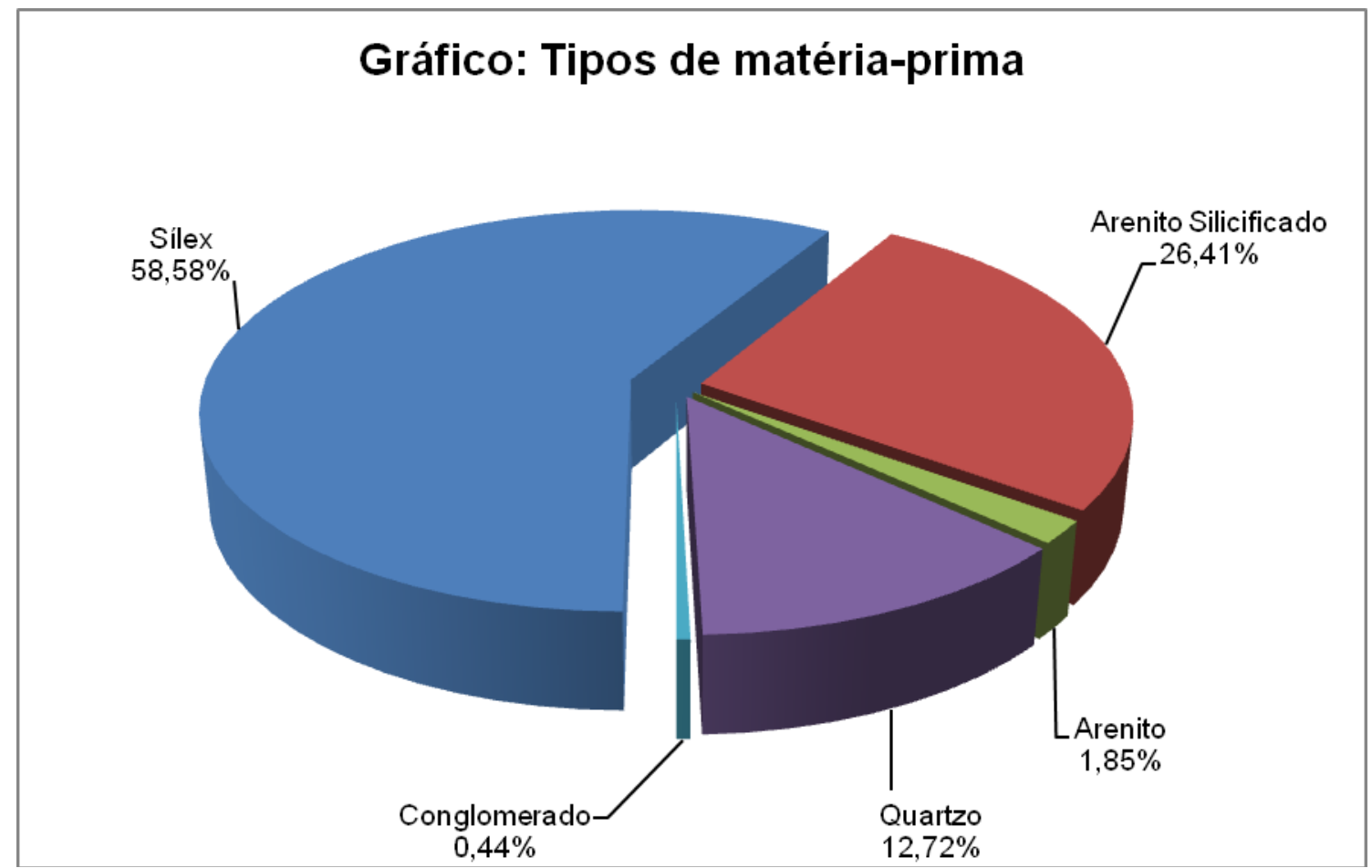

Gráfico 12: Tipos de Matéria-prima

Ainda pode se perceber desse material que 27 peças apresentaram algum tipo de alteração térmica - brilho intenso e cúpulas térmicas - e 17 peças apresentaram pátina.

Observando os exemplares da coleção de núcleos do Sítio Boa Esperança II, podemos identificar uma predominância de peças sobre nódulos de sílex, seguidos de seixos de arenito silicificado. 
Cabe aqui relembrar que o sítio está implantado em um terraço aluvial, em uma área de cascalheira. A abundância desse material proporcionou uma indústria baseada na obtenção de lascas grandes (entre 10 e 15 cm de comprimento), sobre as quais a maioria dos instrumentos foi retocada. A categoria mais representativa da coleção é a das lascas unipolares com 627 exemplares (543 inteiras e 84 fragmentadas), sendo 368 de sílex (58,69\%), 194 de arenito silicificado (30,94\%), 54 de quartzo (08,61\%), 10 de arenito (01,59\%) e 01 de conglomerado $(0,16 \%)$.

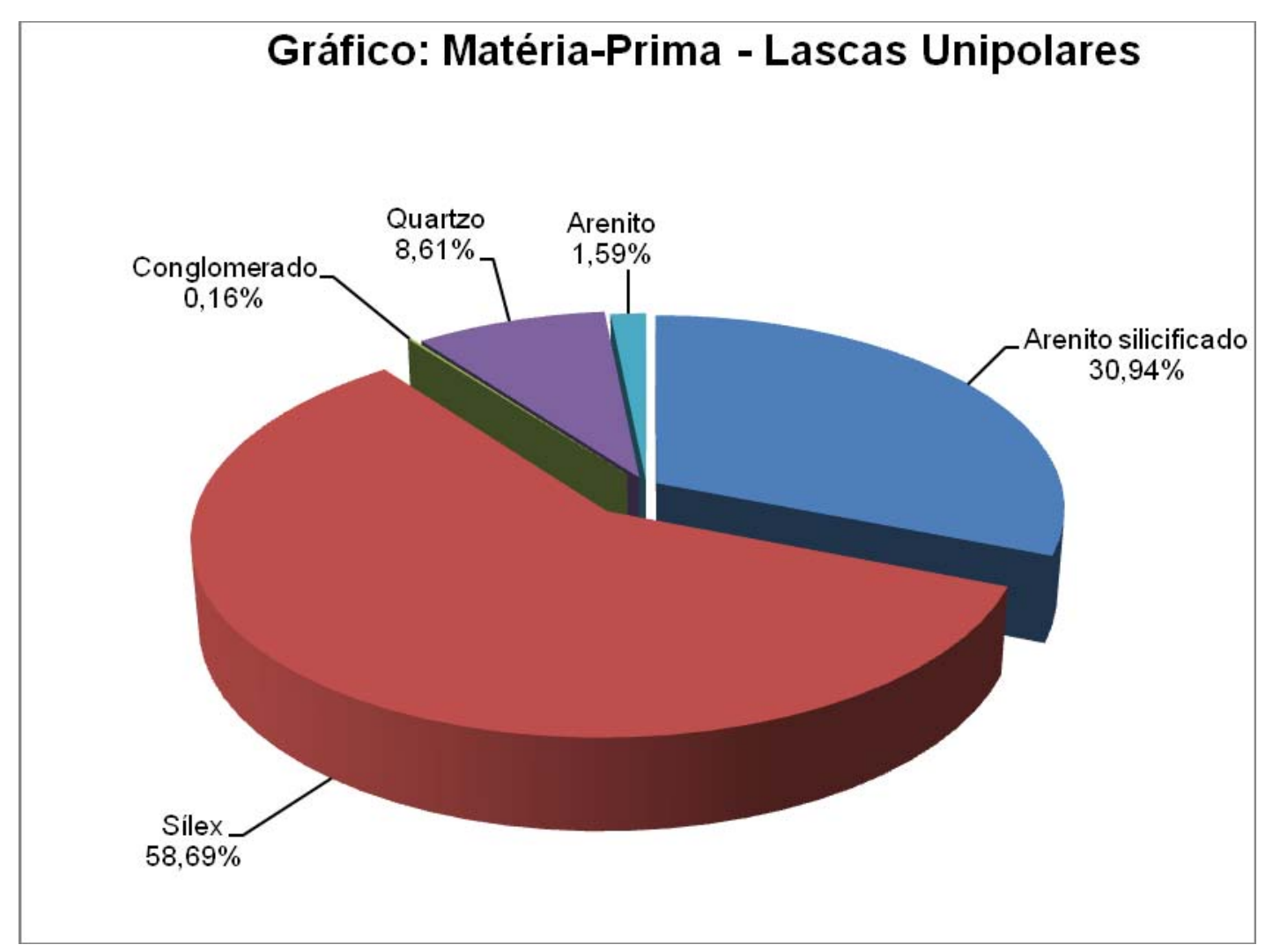

Gráfico 13: Matéria-Prima - Lascas Unipolares 


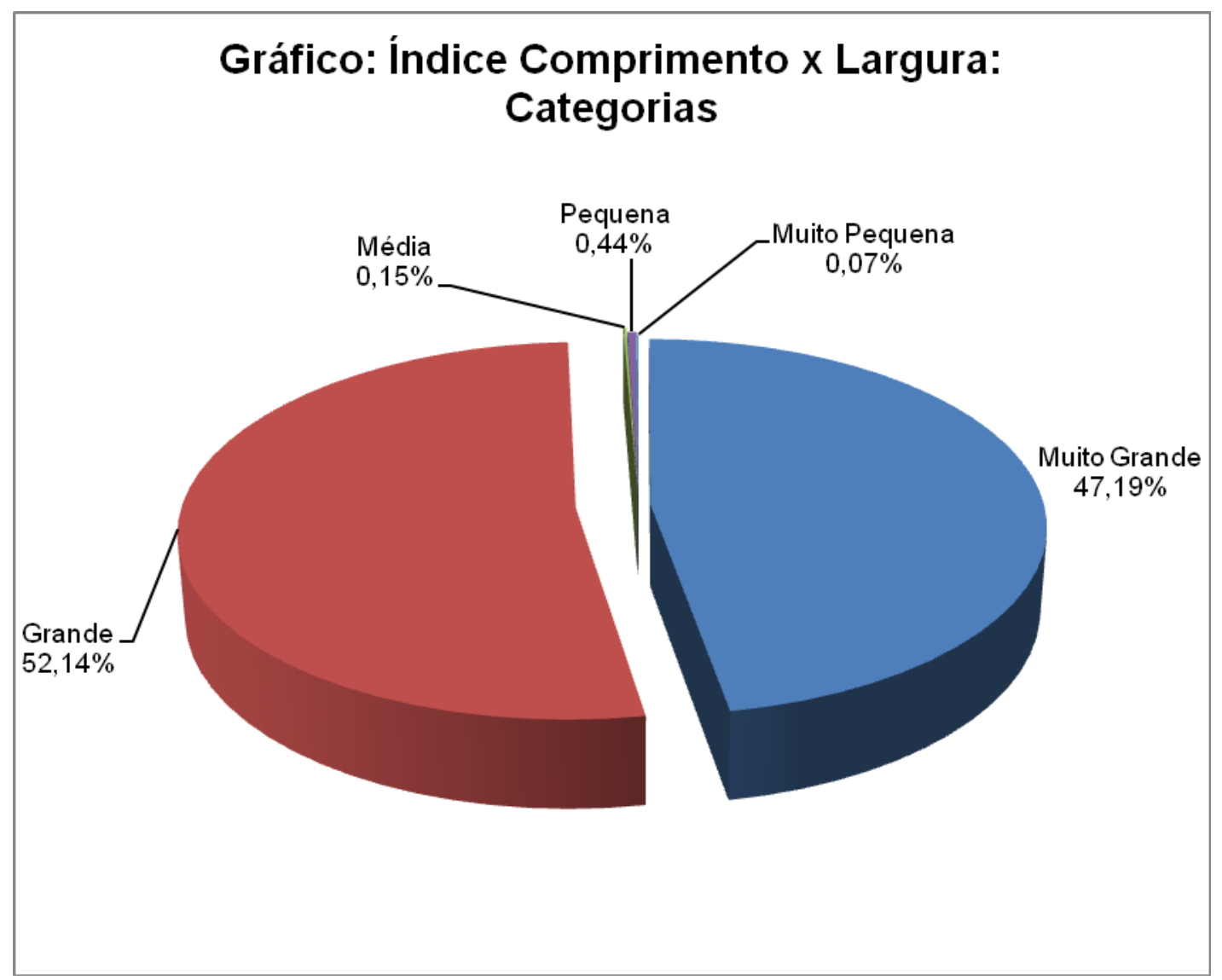

Gráfico 14: Índice Comprimento x Largura: Categorias

Nesse caso, também se evidencia o aproveitamento da matéria-prima disponível na área de implantação do sítio, pois sua indústria de lascas se faz sobre os nódulos e seixos de sílex e arenito silicificado, respectivamente, sendo a produção sobre blocos muito pequena. Teria sido esse, um dos motivos para a escolha do lugar do assentamento. Desse modo, do total de lascas, sobre a identificação do suporte temos 35,89\% Nódulo, 32,06\% seixo, 26,16\% não identificado e 5,90\% bloco. 


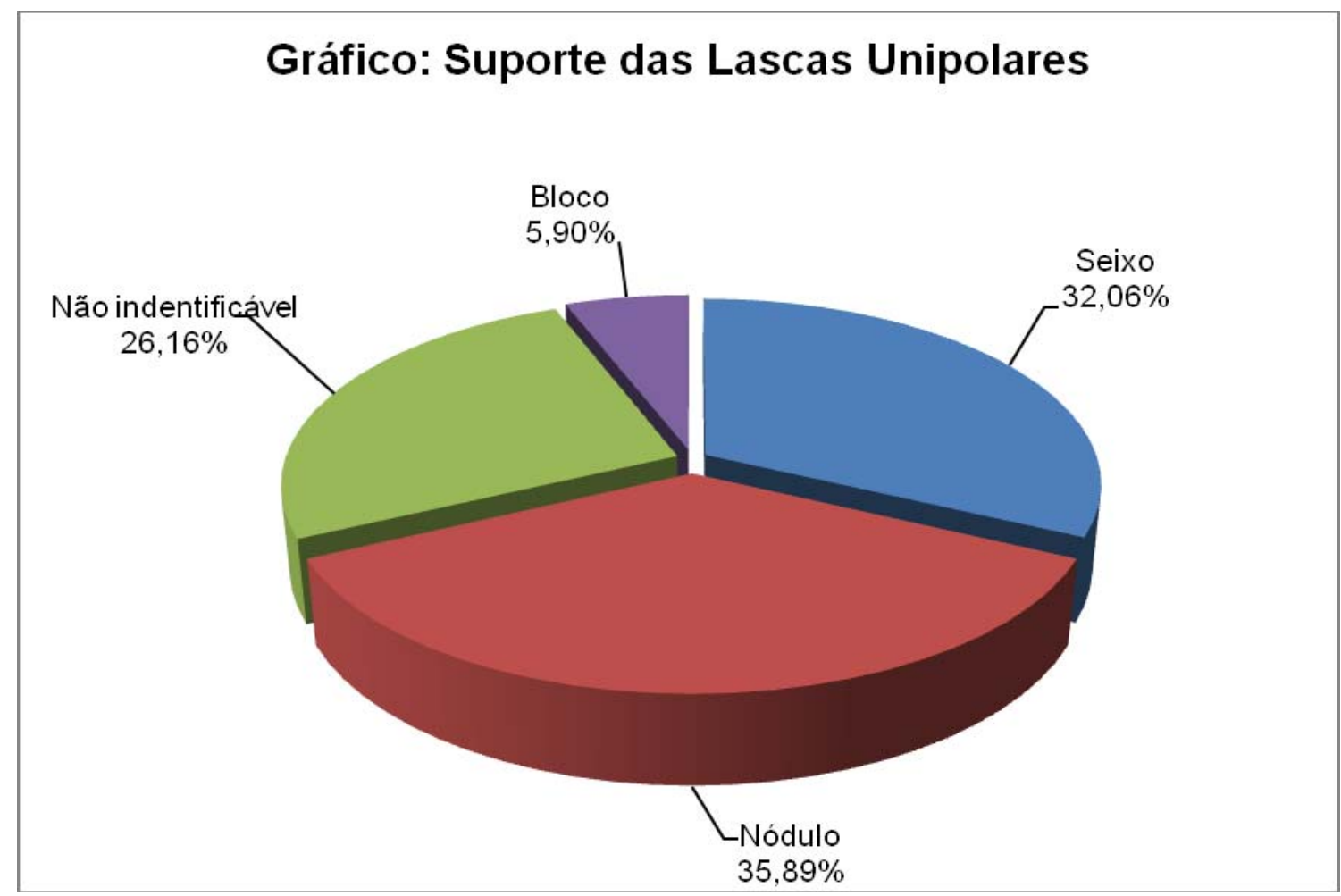

Gráfico 15: Suporte das Lascas Unipolares

Predominam as lascas sem córtex. O que, assim como no Sítio Dois Córregos, também parece estar de acordo com o tipo de indústria em está em análise, ou seja, núcleos de grandes dimensões, onde a exploração da matéria-prima é principalmente direcionada para suportes de grandes volumes. Os núcleos grandes permitem a retirada de grande quantidade de lascas sem córtex antes do esgotamento. Esse parece ser o fator responsável pela predominância de lascas sem córtex. Temos assim, os núcleos com as medidas entre $150 \mathrm{~mm}$ para o comprimento; $150 \mathrm{~mm}$ para a largura e $85 \mathrm{~mm}$ para a espessura. 


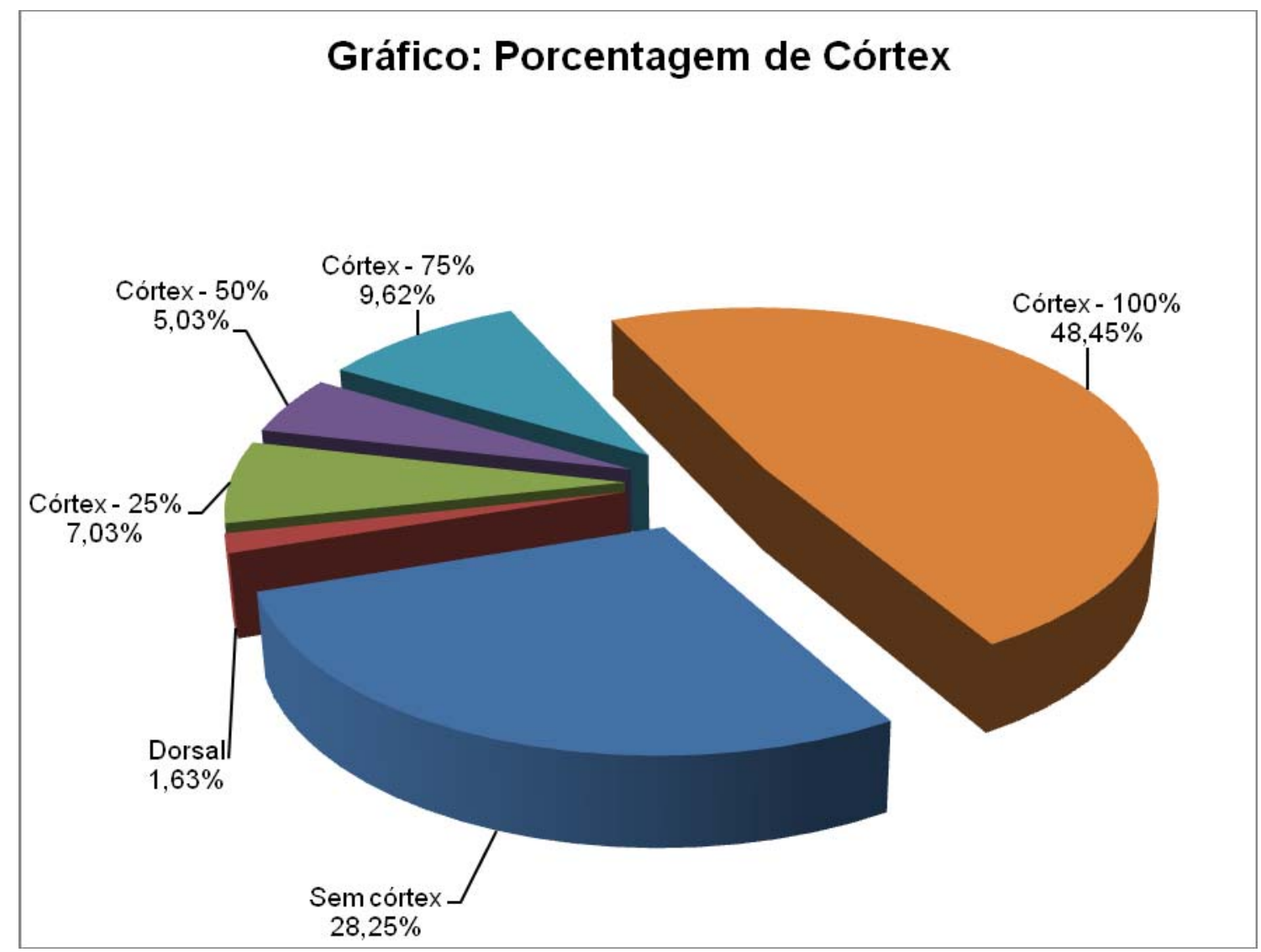

Gráfico 16: Porcentagem de Córtex na face externa

Sobre a morfologia dos talões, destacam-se os talões lisos, indicando no Sítio BES II, o não cuidado com a preparação do plano de percussão dos núcleos. Em seguida estão os talões corticais, que evidenciam o ato inicial do lascamento, onde as lascas são destacadas de seu suporte. 


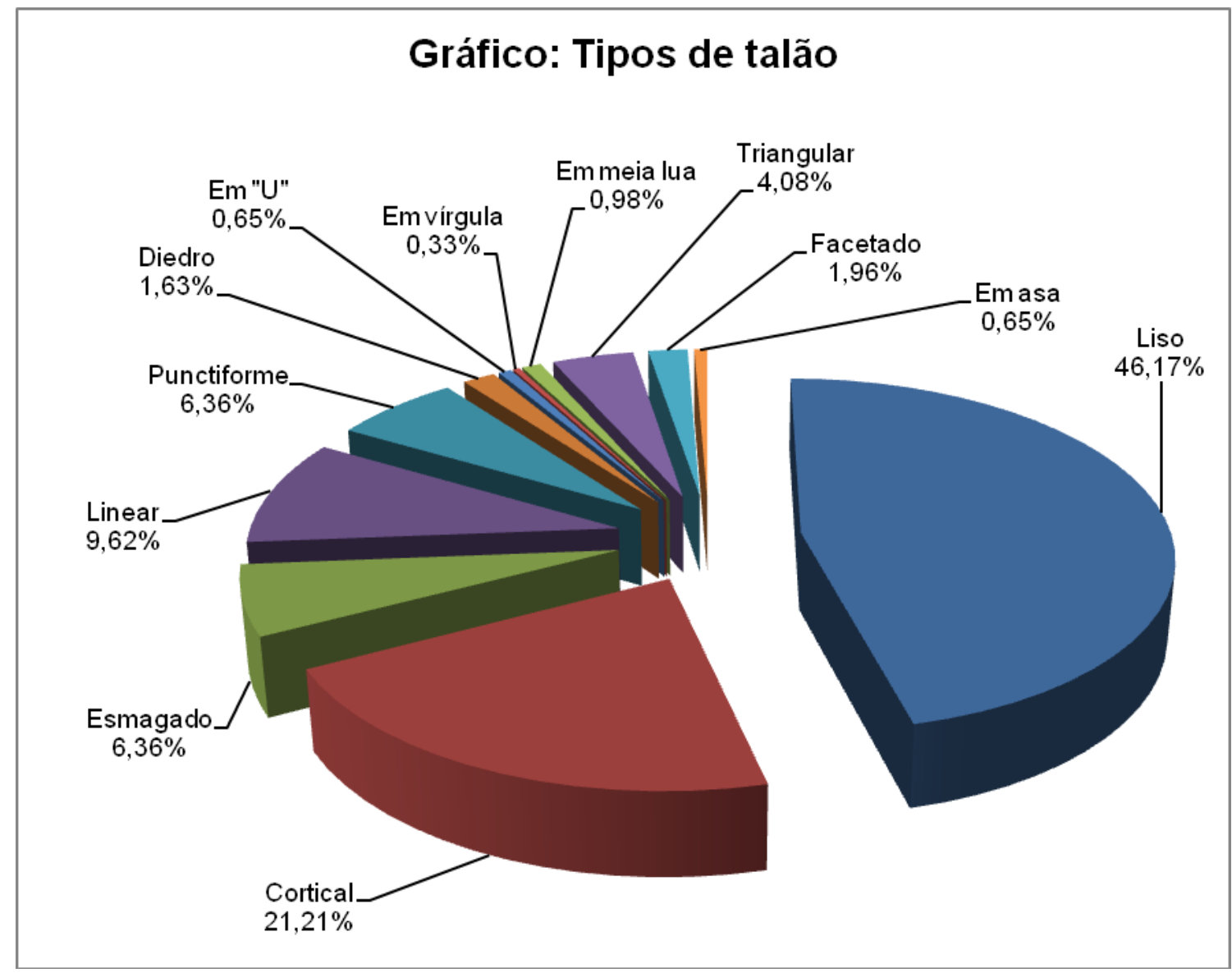

Gráfico 17: Tipos de Talão

A morfologia das lascas do Sítio BES II também é variada nos levando a mesma suposição do sítio Dois Córregos, quer dizer, que não havia um planejamento muito padronizado do módulo do suporte a ser retocado, os núcleos não apresentam seqüências de lascamento organizadas, os instrumentos não são uniformes e não há padronização morfológica das lascas retiradas. Os suportes com dimensões adequadas e boa qualidade da matéria-prima eram aproveitados independente da forma. 


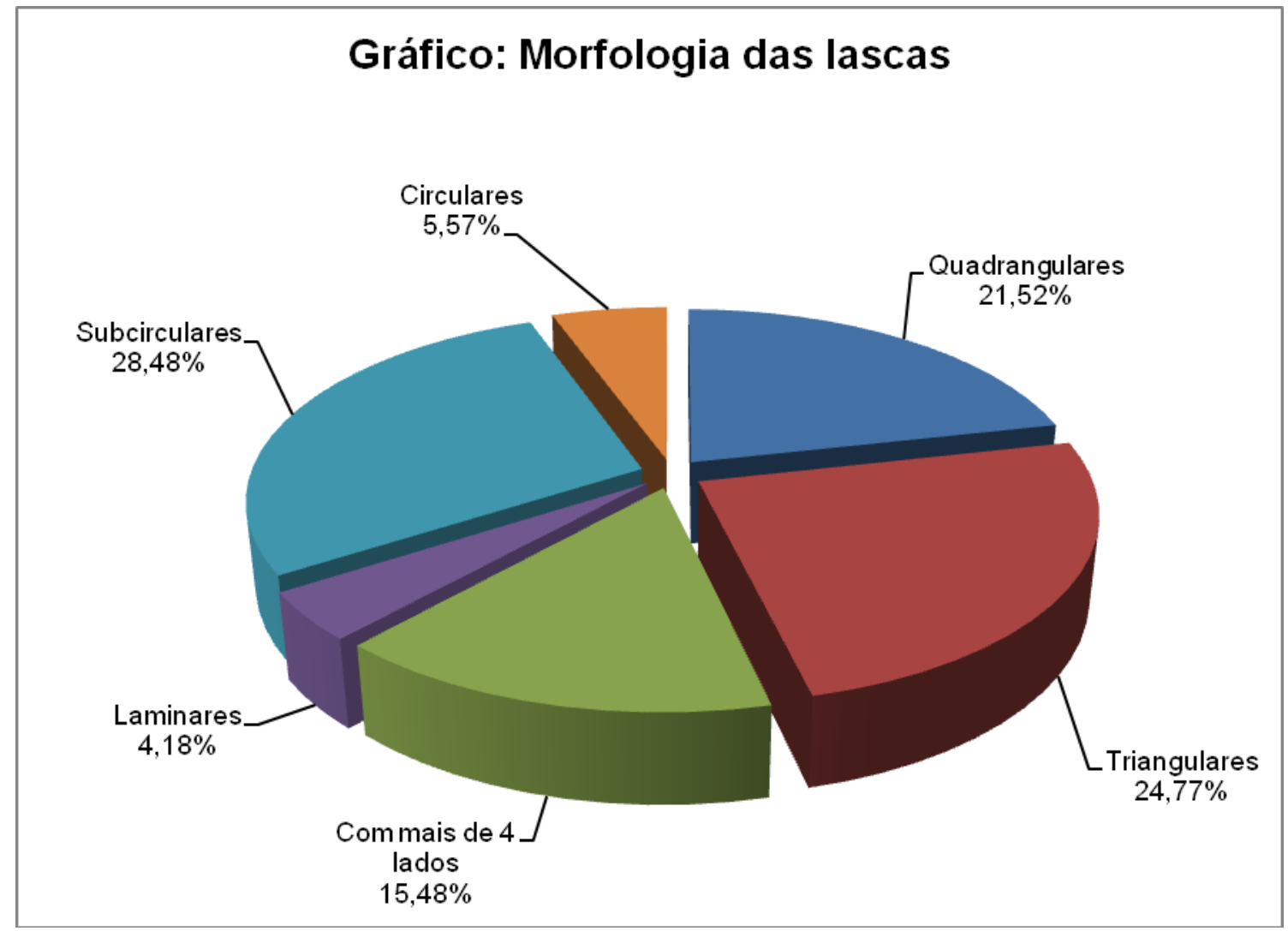

Gráfico 18: Morfologia das Lascas

Os acidentes de lascamento foram verificados em 34,61\% das lascas analisadas. Predomina a ocorrência de ultrapassantes, seguidas por transbordantes, lingüetas, sirets e refletidas. 


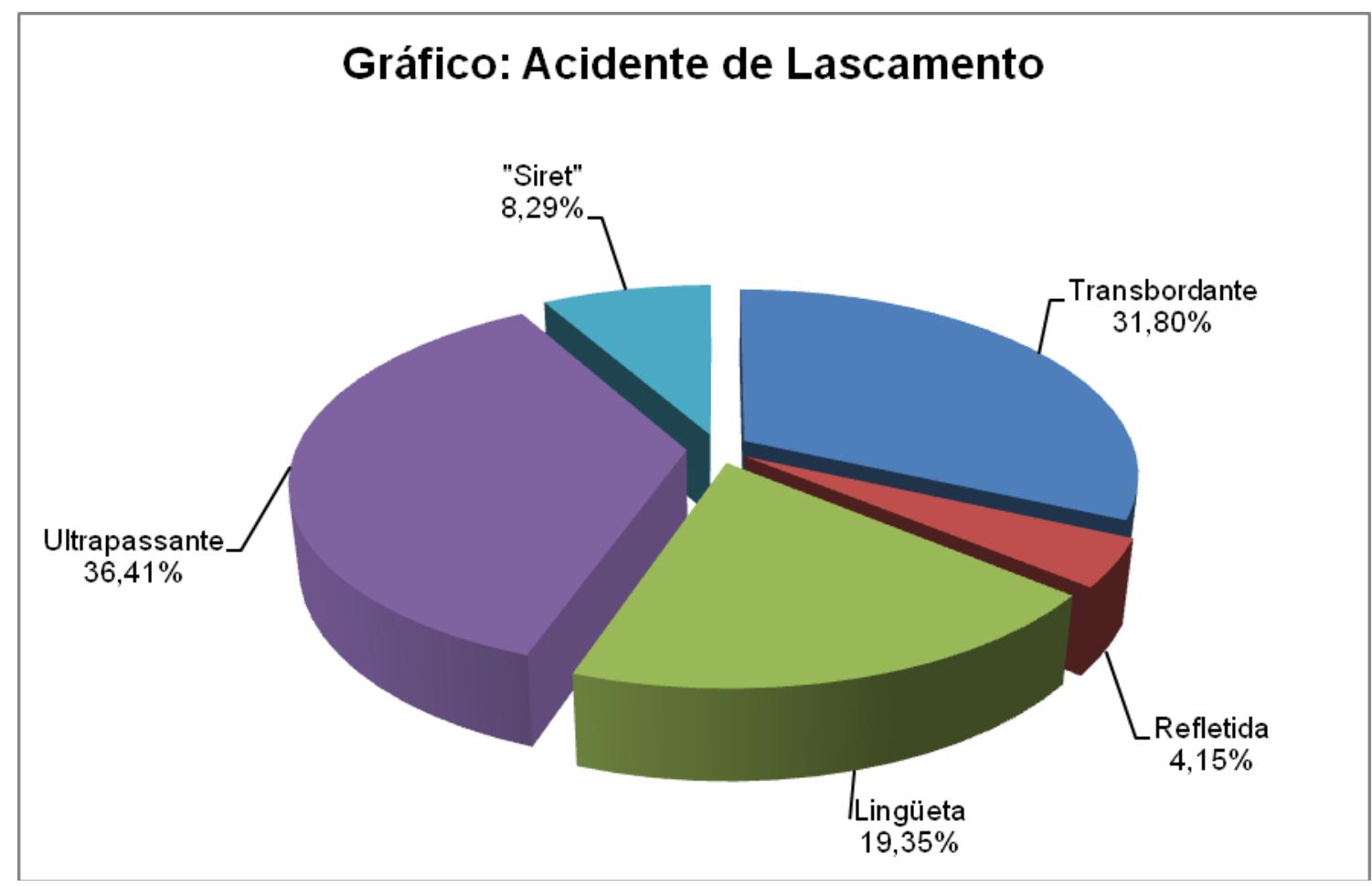

Gráfico 19: Acidente de lascamento

Quanto à cadeia operatória na confecção dos instrumentos, podemos perceber que seguiram na maior parte dos casos a seguinte seqüência: suporte selecionado > destacamento da lasca $>$ retoques $>$ abandono. Contando também com algumas variantes, em menor número, de acidente de lascamento, fragmentação, formatação do artefato, reciclagem e marcas recentes. Predominam, como já mencionamos, as lascas de tamanho grande, sendo as maiores selecionadas como suporte para os instrumentos. Vale ressaltar que nesse sítio ainda foi encontrada uma única lasca bipolar, em contexto com um único núcleo bipolar.

Dos 40 instrumentos coletados, 35 são de gume retocado unifacialmente, inteiros ou fragmentados, principalmente produzidos sobre lascas grandes. Temos 2 perfuradores, um em sílex, assimilado a uma ponta de lança, porém sem grandes retoques e com pedúnculo. O outro possui forma assemelhada a de buril, e é de arenito silicificado. Há ainda 2 instrumentos de gume bruto e um instrumento passivo - uma bigorna - com marcas bem evidentes, que denunciam uso intenso. A matéria-prima mais usada na confecção desses instrumentos foi predominantemente o arenito silicificado, seguido do sílex. A média das medidas está entre $135 \mathrm{~mm}$ para o comprimento; $75 \mathrm{~mm}$ para a largura e $40 \mathrm{~mm}$ para a espessura. 
Quanto aos bordos ativos dos instrumentos, percebemos a predominância dos ângulos mais abruptos, entre 50 e $70^{\circ}$, que indicariam atividades para raspagem, seguidos dos ângulos rasantes, entre 40 e $25^{\circ}$, que indicariam atividade de corte. Também há os instrumentos de perfuração. Esse quadro nos mostra ser o Sítio BES II um assentamento de atividades diversificadas, o que, corroborando com a intensidade de material e extensão da área tanto horizontal, quanto vertical, aponta para uma habitação.

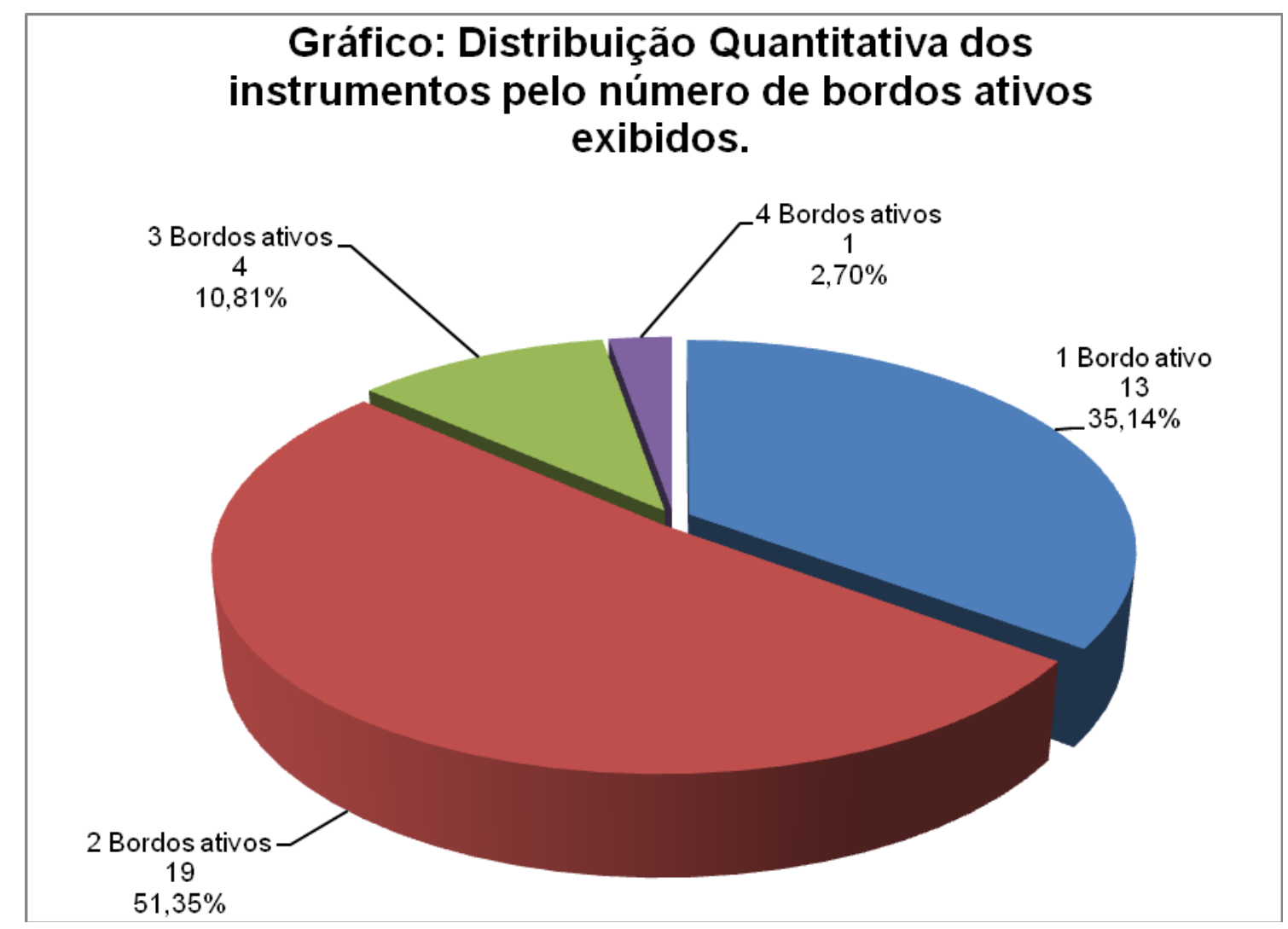

Gráfico 20: Distribuição Quantitativa dos Utensílios pelo Número de Bordos Ativos Exibido 


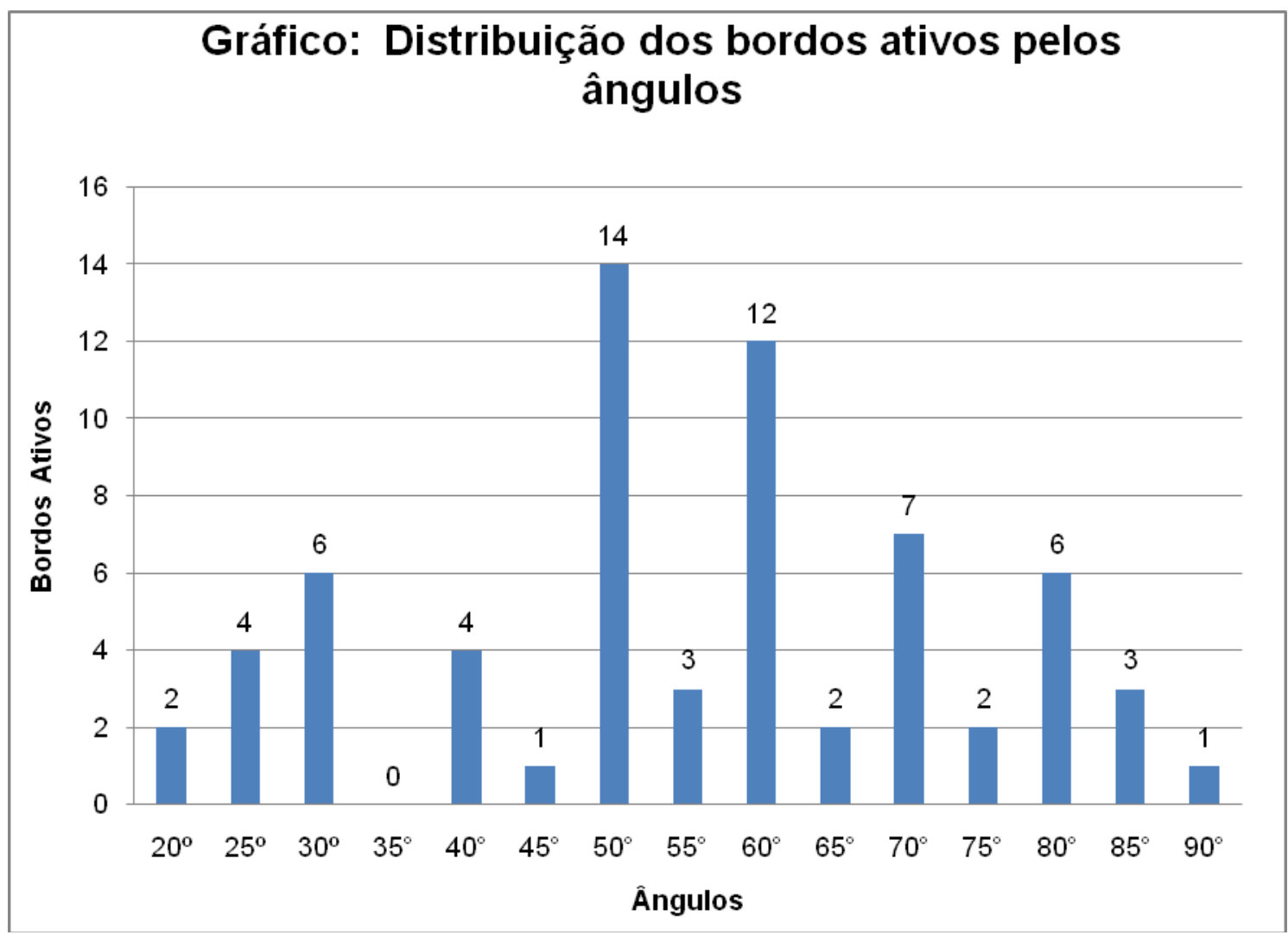

Gráfico 21: Distribuição dos Bordos Ativos pelos ângulos

A descrição um pouco mais detalhada dos instrumentos do sítio BES II pode ser vista nas pranchas apresentadas a seguir, com a exibição das peças consideradas mais representativas da coleção. ${ }^{21}$

${ }^{21}$ Os desenhos dos instrumentos dos Sítios BES II e BES III, aqui apresentados, foram feitos pelo autor do presente trabalho 

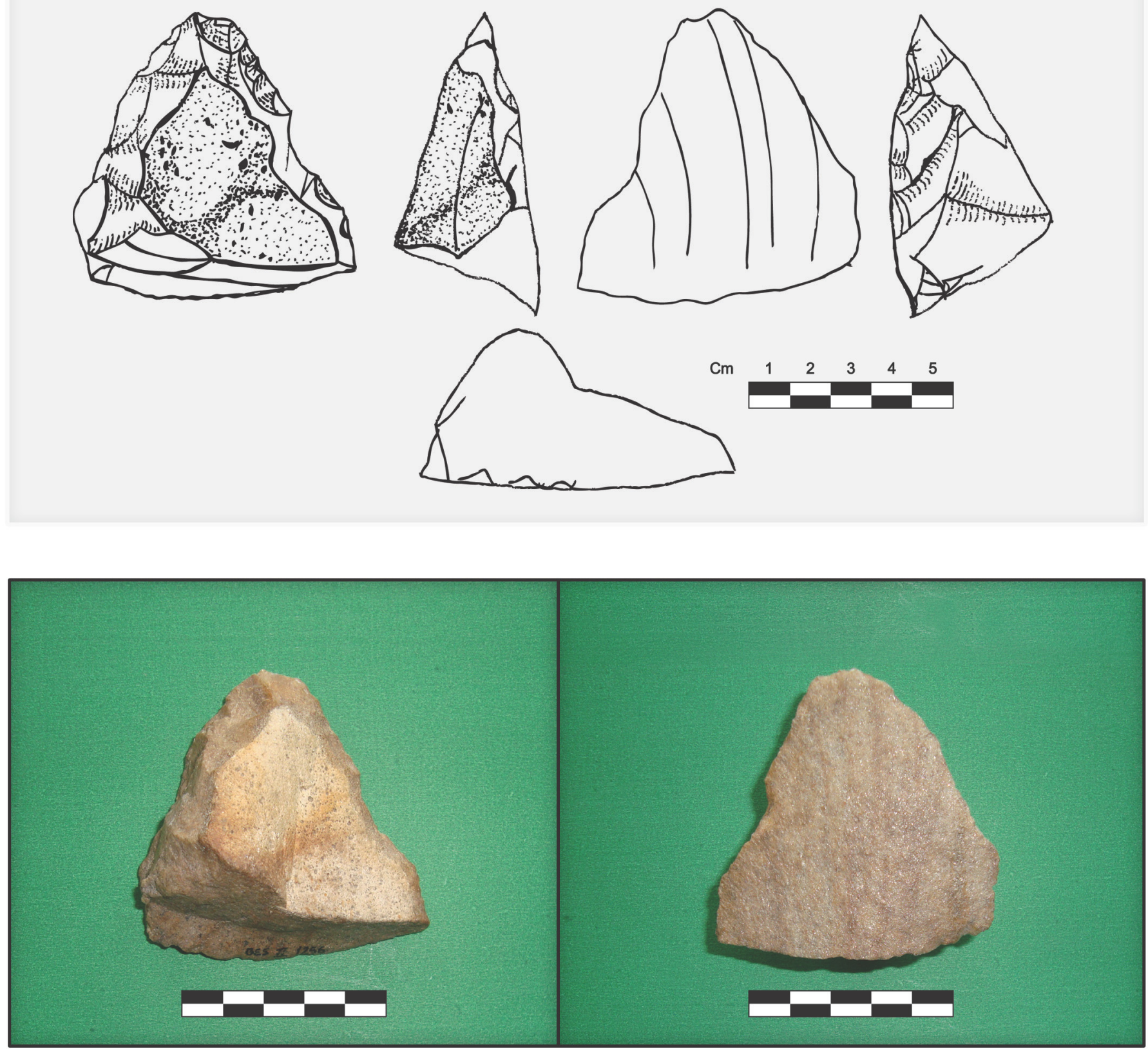

BES II 1256

Instrumento formal sobre fragmento de lasca

BORDOS ATIVOS: $2-60^{\circ}, 80^{\circ}$

DIMENSÕES:

Comprimento: $67 \mathrm{~mm}$

Largura: $66 \mathrm{~mm}$

Espessura: $37 \mathrm{~mm}$

MATÉRIA-PRIMA: Arenito Silicificado

FORMA/DESCRIÇÃO: Prisma triangular, com córtex na face externa, com retiradas nas duas laterais de maneira a criar dois bordos ativos. Ambos os bordos possuem diversos retoques. Em um deles os retoques são diretos, curtos, sub-paralelos e descontínuos, com maior incidência na parte distal. O outro bordo possui retoques diretos escalariformes e também ao longo de toda sua extensão. $O$ perfil de ambos os bordos retocados é irregular. A forma do utensílio e os ângulos dos bordos ativos sugerem uma única função.

MUSEU DE ARQUEOLOGIA E ETNOLOGIA DA UNIVERSIDADE DE SÃO PAULO SÍTIOS LÍTICOS NO INTERIOR PAULISTA: UM ENFOQUE REGIONAL 

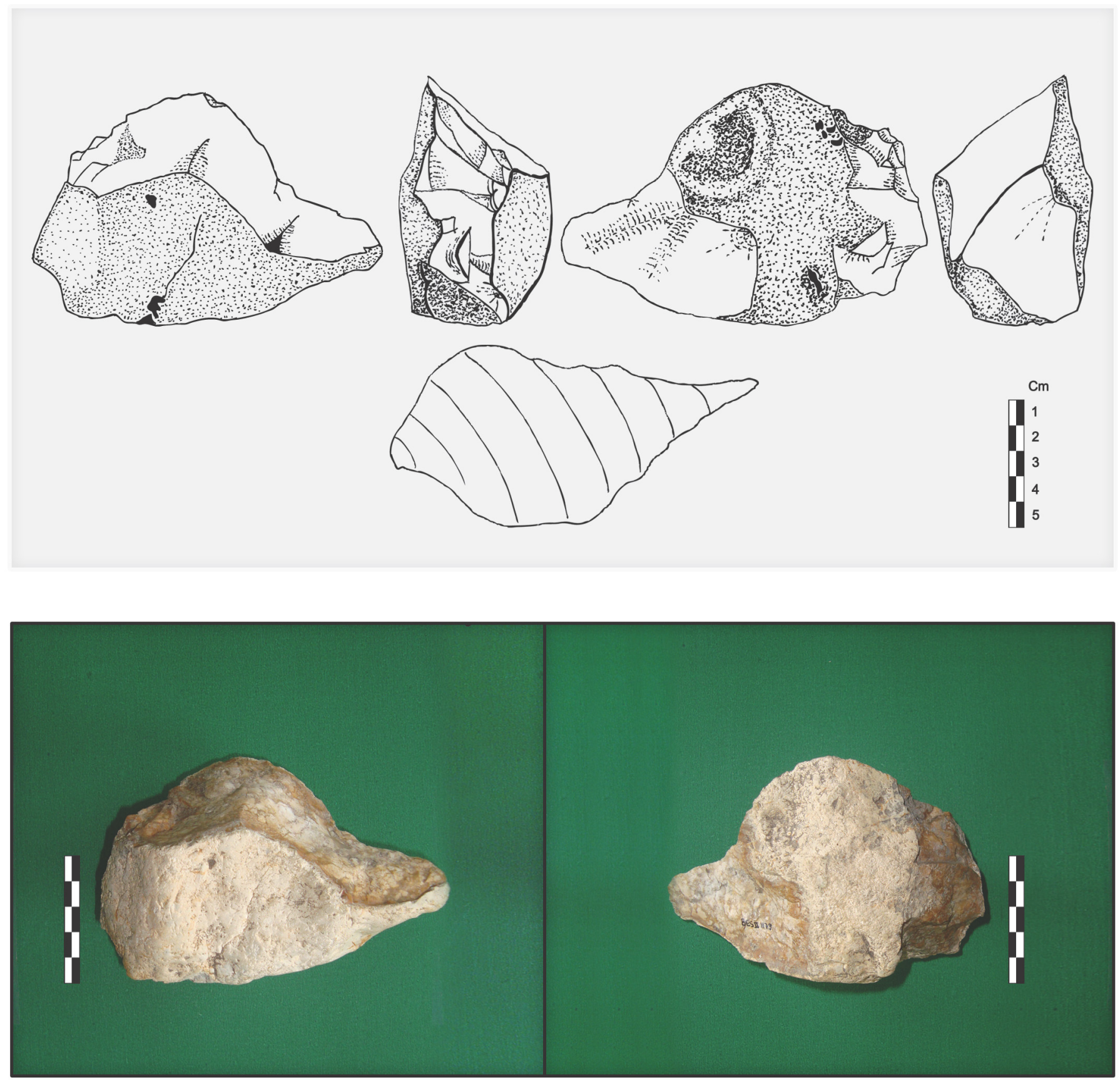

PEÇA BES II 1179

Instrumento informal sobre nódulo

BORDOS ATIVOS: $2-50^{\circ}, 80^{\circ}$

DIMENSÕES

Comprimento: $120 \mathrm{~mm}$

Largura: 79 mm

Espessura: $46 \mathrm{~mm}$

MATÉRIA-PRIMA: Sílex

FORMA/DESCRIÇÃO

Prisma Sub-circular, com $75 \%$ de cortex, com retiradas bifaciais no sentido de formar um gume que se estende por toda uma de suas laterais, sendo que o ângulo formado na parte mais larga (proximal) é mais abrupto $\left(80^{\circ}\right)$, enquanto que o ângulo formado na parte mais delgada (distal) é semi abrupto $\left(50^{\circ}\right)$. A forma do utensílio e os ângulos formados pelos bordos ativos sugerem 1 função.

MUSEU DE ARQUEOLOGIA E ETNOLOGIA DA UNIVERSIDADE DE SÃO PAULO SÍTIOS LÍTICOS NO INTERIOR PAULISTA: UM ENFOQUE REGIONAL 

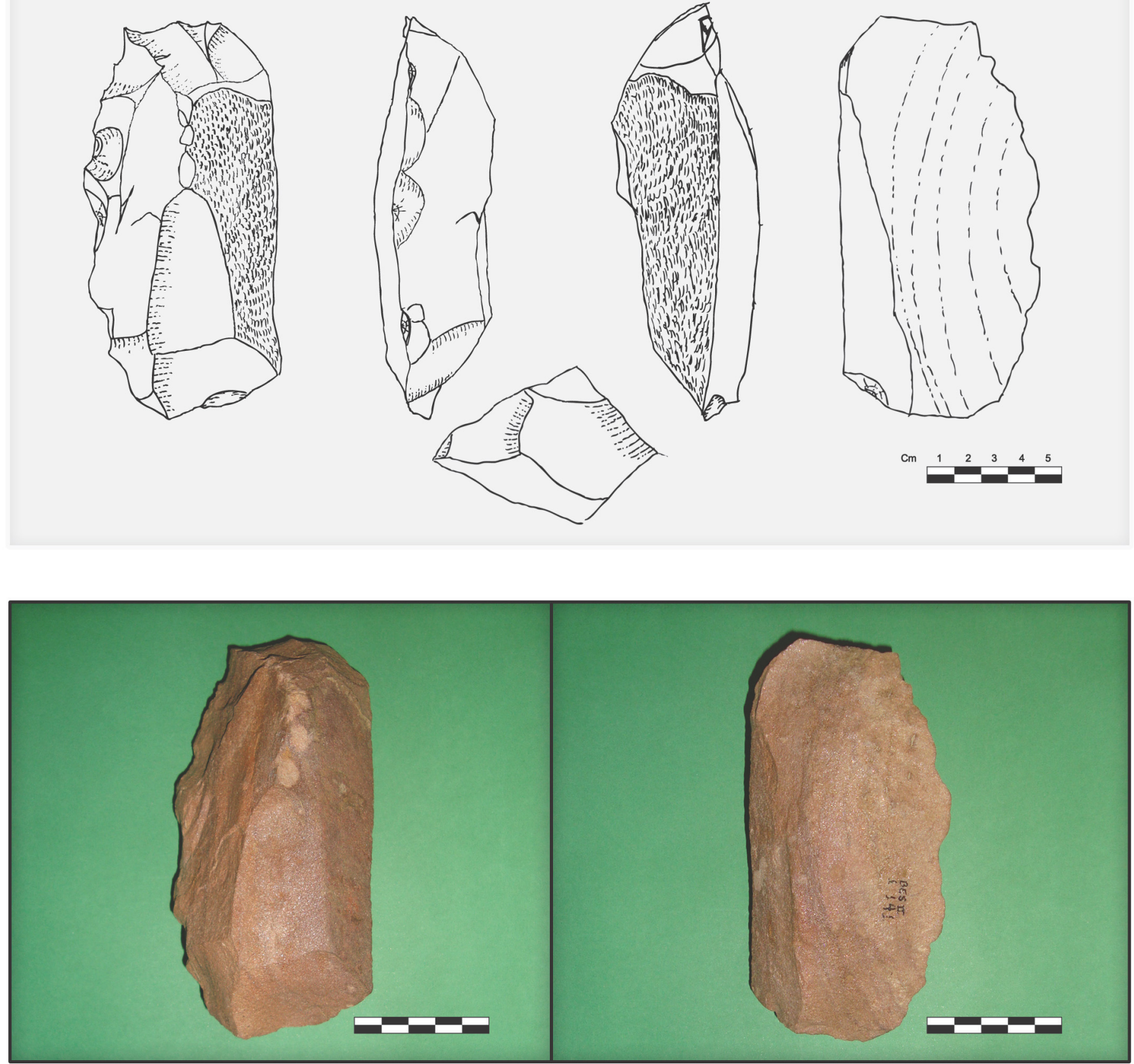

\section{PEÇA BES II 1141}

Instrumento informal sobre bloco

BORDOS ATIVOS: $3-85^{\circ}, 80^{\circ}, 85^{\circ}$

\section{DIMENSÕES}

Comprimento: $140 \mathrm{~mm}$

Largura: $70 \mathrm{~mm}$

Espessura: $48 \mathrm{~mm}$

MATÉRIA-PRIMA: Arenito

\section{FORMA/DESCRIÇÃO}

Prisma retangular, com cortex na face externa, retiradas unifaciais e dois gumes frontais (parte distal) e um gume que se estende por toda uma de suas laterais, sendo que este recebeu retoques diretos, descontínuos ao longo de todo o bordo ativo, formando um perfil de gume irregular.. A forma do utensílio e ângulos dos bordos sugerem 1 função.

MUSEU DE ARQUEOLOGIA E ETNOLOGIA DA UNIVERSIDADE DE SÃO PAULO SÍTIOS LÍTICOS NO INTERIOR PAULISTA: UM ENFOQUE REGIONAL 

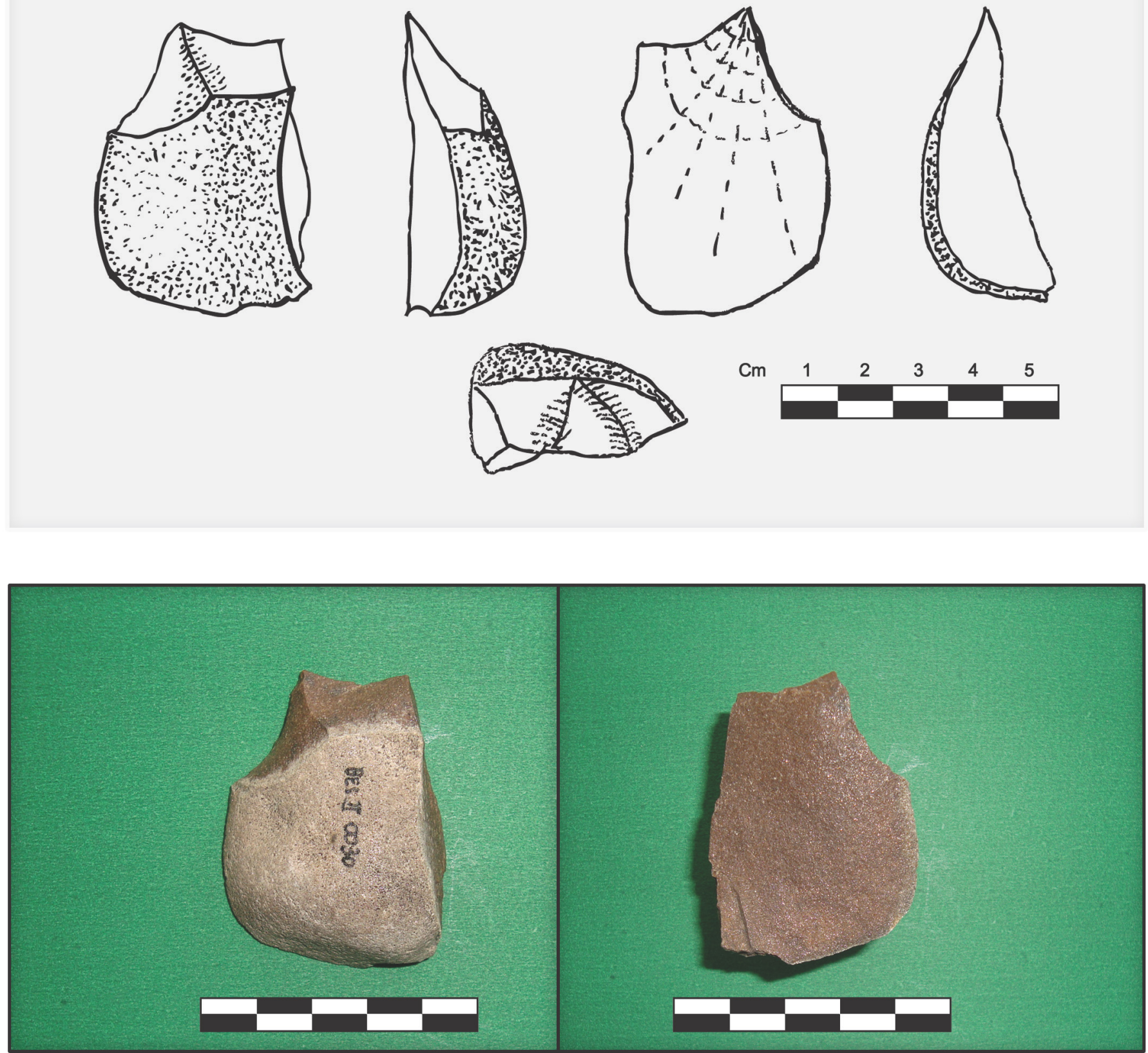

PEÇA BES II 0030

Instrumento informal sobre fragmento de lasca unipolar

SUPORTE: seixo

BORDOS ATIVOS: $2-50^{\circ}, 60^{\circ}$

DIMENSÕES

Comprimento: $49 \mathrm{~mm}$

Largura: $37 \mathrm{~mm}$

Espessura: $18 \mathrm{~mm}$

MATÉRIA-PRIMA: Arenito Silicificado

FORMA/DESCRIÇÃO

Prisma sub-circular, com cortex na face externa, 2 retiradas frontais (distais) que compõe seus dois bordos ativos, cujos ângulos sugerem 1 função.

MUSEU DE ARQUEOLOGIA E ETNOLOGIA DA UNIVERSIDADE DE SÃO PAULO SÍTIOS LÍTICOS NO INTERIOR PAULISTA: UM ENFOQUE REGIONAL 

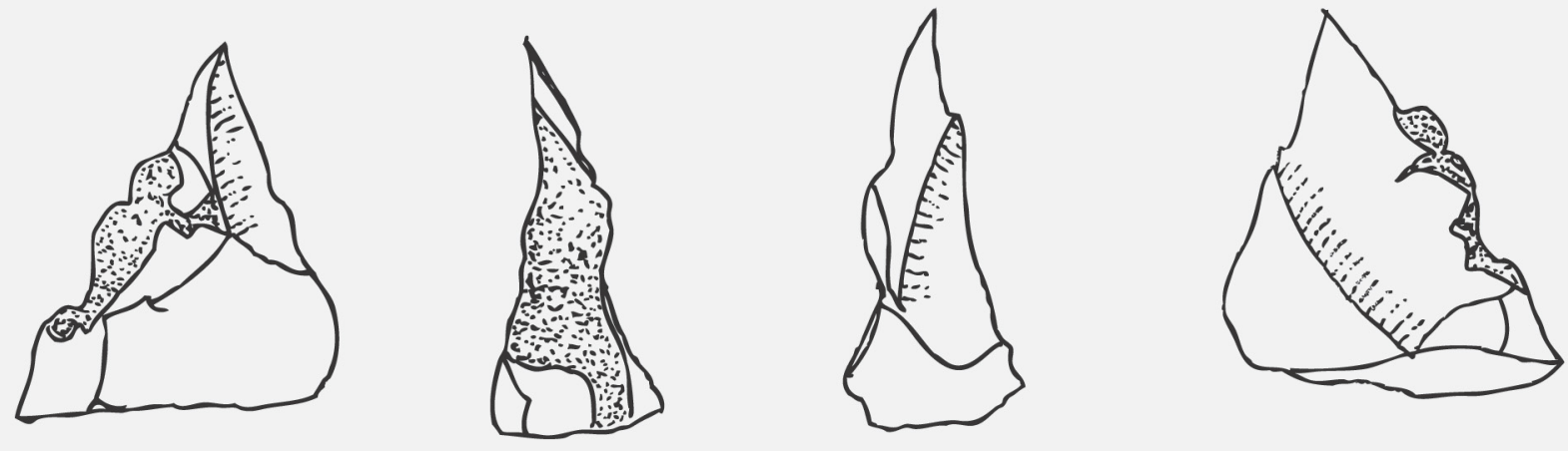

$\mathrm{Cm}$
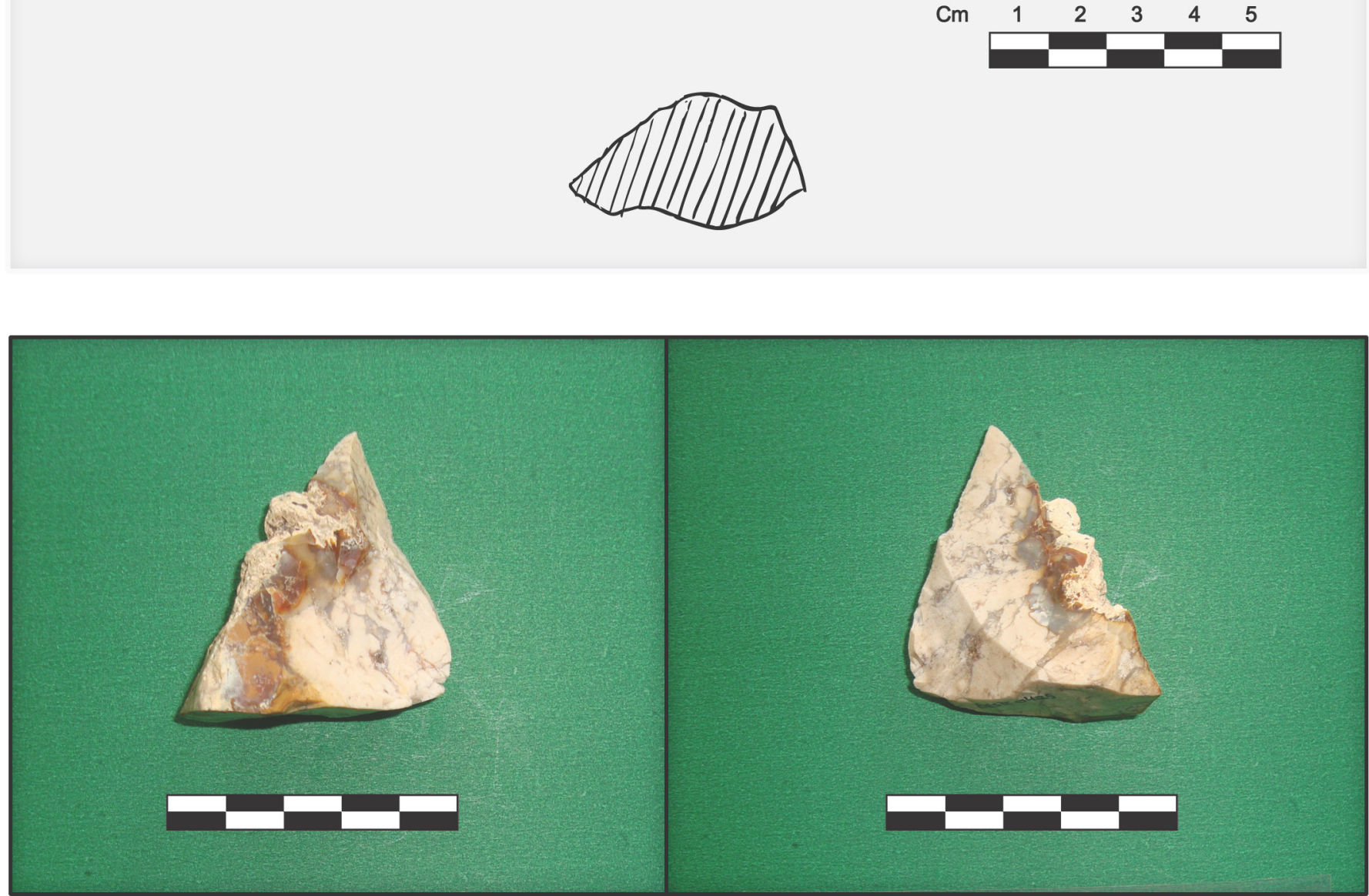

PEÇA BES II 0425

Instrumento informal sobre lasca unipolar

SUPORTE: nódulo

BORDOS ATIVOS: $1-40^{\circ}$

ÂNGULO DO TALÃO: $85^{\circ}$

DIMENSÕES

Comprimento: $47 \mathrm{~mm}$

Largura: $41 \mathrm{~mm}$

Espessura: $20 \mathrm{~mm}$

MATÉRIA-PRIMA: Sílex

FORMA/DESCRIÇÃO

Prisma triangular com um bordo ativo em uma de suas laterais, com um vértice pontiagudo. Sua forma e ângulo do bordo sugerem 2 funções.

MUSEU DE ARQUEOLOGIA E ETNOLOGIA DA UNIVERSIDADE DE SÃO PAULO SIITIOS LIITICOS NO INTERIOR PAULISTA: UM ENFOQUE REGIONAL
Sítio Boa Esperança II

Boa Esperança do Sul, SP 

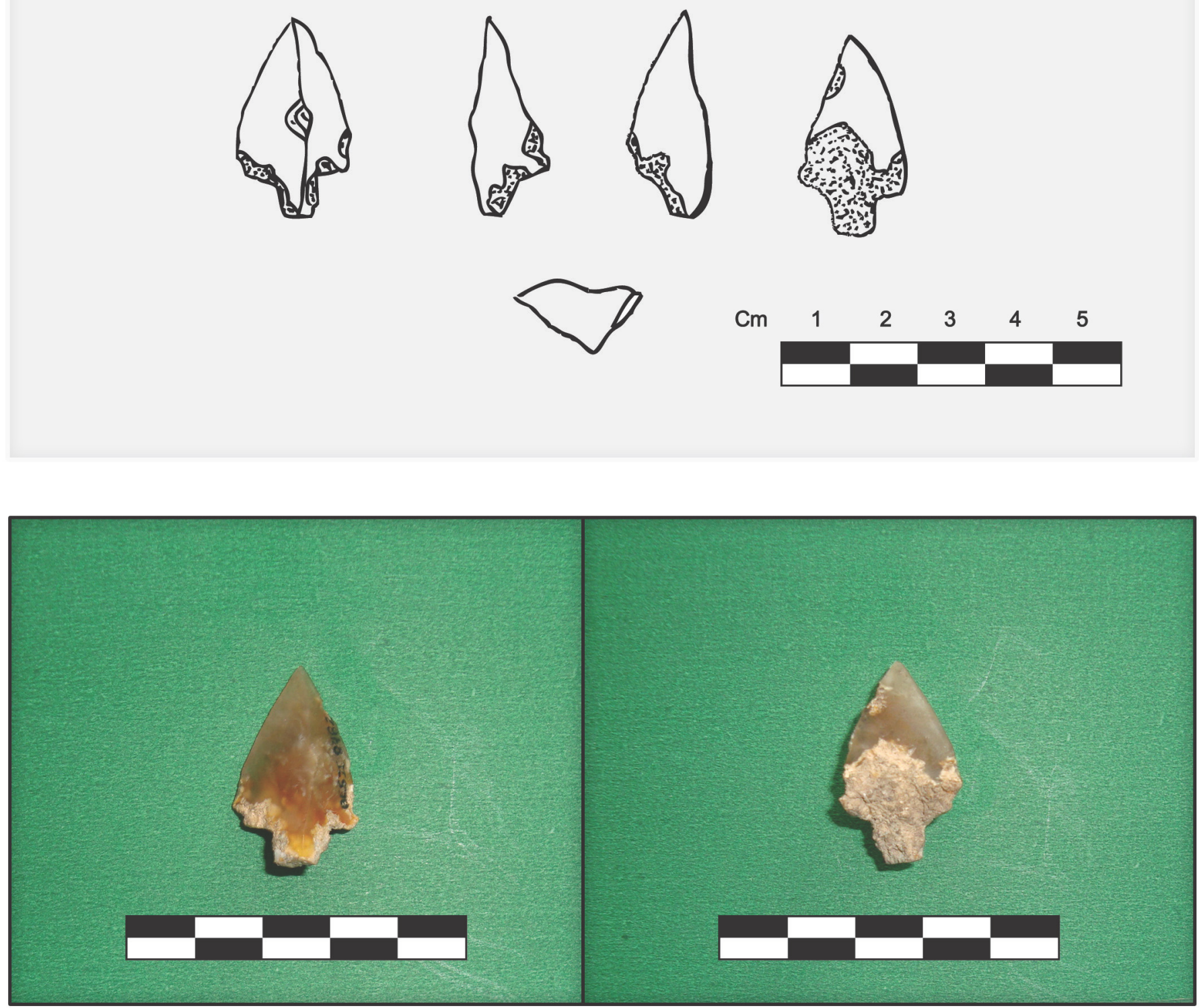

\section{BES II 0482}

Instrumento informal sobre fragmento de lasca

BORDOS ATIVOS: $2-30^{\circ}, 35^{\circ}$

DIMENSÕES:

Comprimento: $30 \mathrm{~mm}$

Largura: $16 \mathrm{~mm}$

Espessura: $10 \mathrm{~mm}$

MATÉRIA-PRIMA: sílex

FORMA/DESCRIÇÃO: Prisma triangular, com córtex na face externa, com retiradas a fim de produzir um vértice pontiagudo cuja forma e ângulos sugerem uma função.

MUSEU DE ARQUEOLOGIA E ETNOLOGIA DA UNIVERSIDADE DE SÃO PAULO SÍTIOS LÍTICOS NO INTERIOR PAULISTA: UM ENFOQUE REGIONAL 

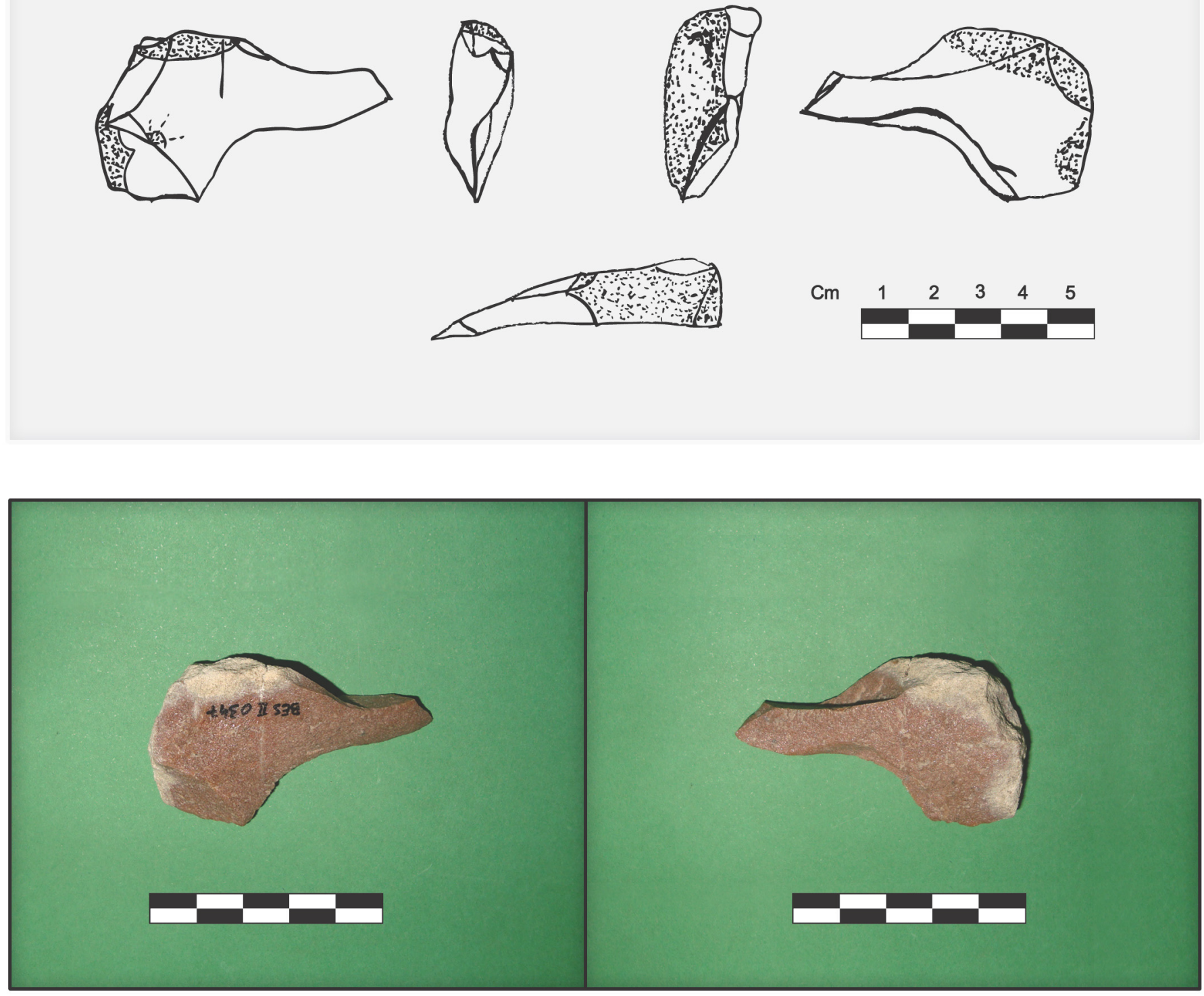

PEÇA BES II 0347

Instrumento informal sobre lasca unipolar

SUPORTE: nódulo

ÂNGULO DO TALÃO: $130^{\circ}$

DIMENSÕES

Comprimento: $39 \mathrm{~mm}$

Largura: $57 \mathrm{~mm}$

Espessura: $15 \mathrm{~mm}$

MATÉRIA-PRIMA: Arenito Silicificado

FORMA/DESCRIÇÃO

Prisma puntiforme, com presença de córtex, destacando sua funcionalidade para furar, ou seja, utensílio que sugere 1 função.

MUSEU DE ARQUEOLOGIA E ETNOLOGIA DA UNIVERSIDADE DE SÃO PAULO SÍTIOS LÍTICOS NO INTERIOR PAULISTA: UM ENFOQUE REGIONAL 

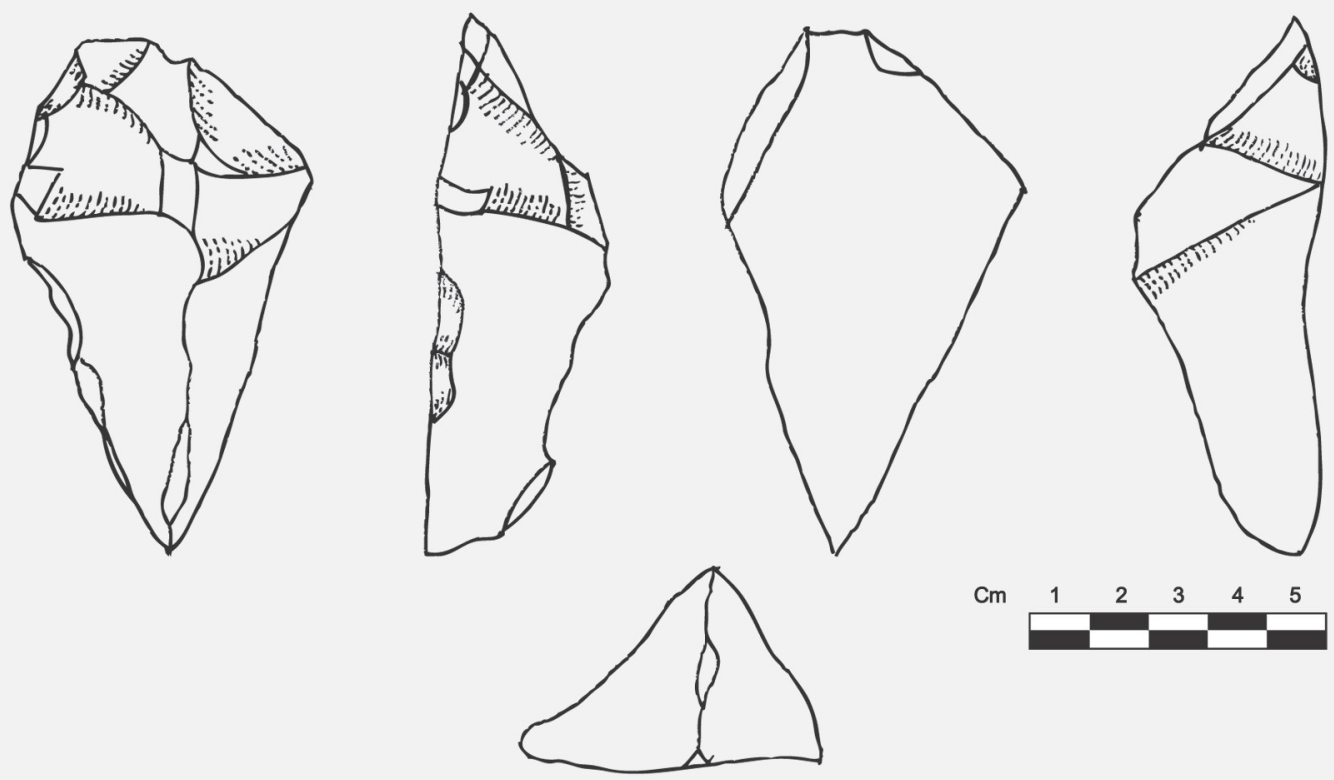

$\mathrm{Cm}$
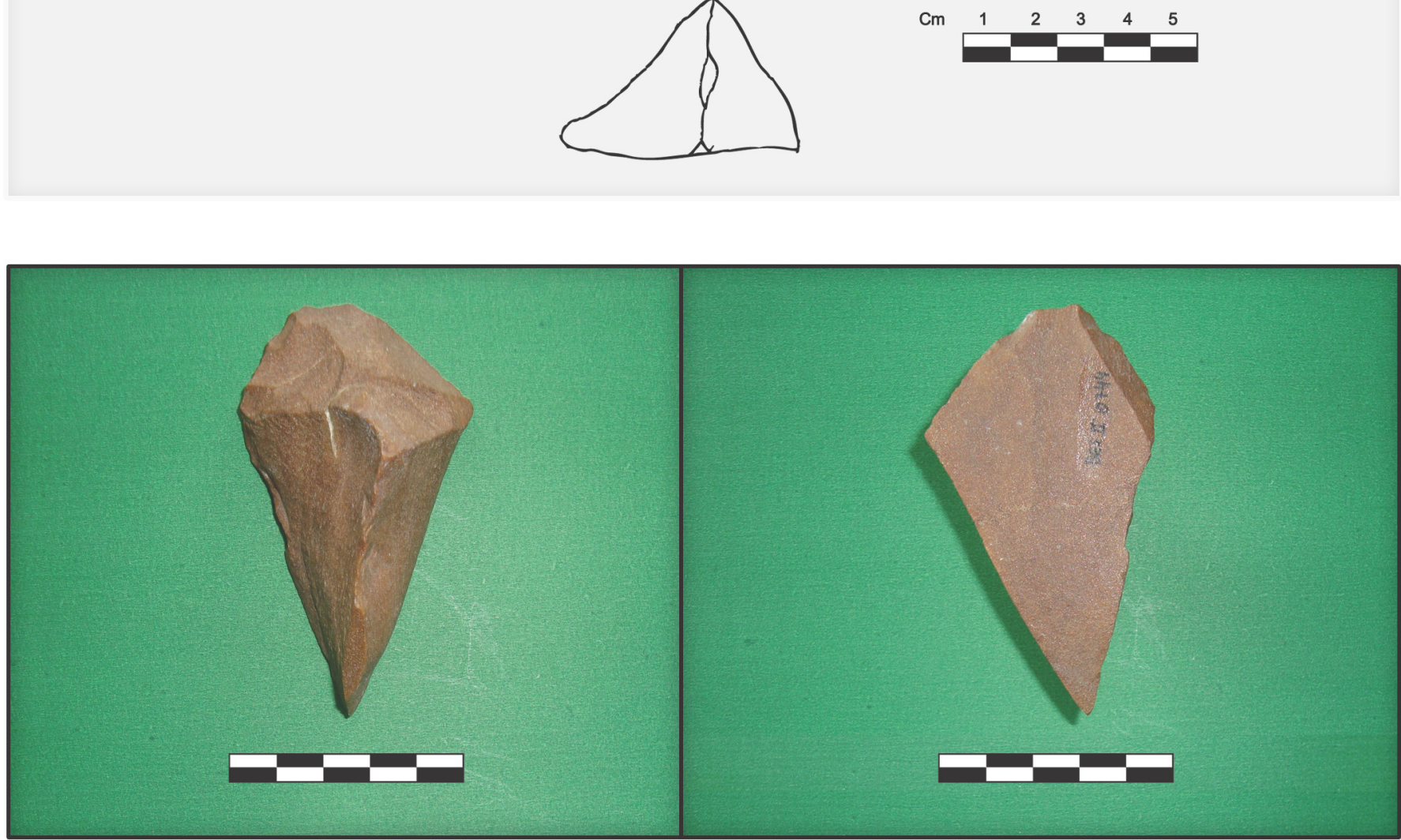

\section{BES II 0744}

Instrumento informal sobre bloco

BORDOS ATIVOS: 2 - $35^{\circ}, 60^{\circ}$

DIMENSÕES:

Comprimento: $86 \mathrm{~mm}$

Largura: $47 \mathrm{~mm}$

Espessura: $32 \mathrm{~mm}$

MATÉRIA-PRIMA: Arenito Silicificado

FORMA/DESCRIÇÃO: Prisma, sem córtex, com uma borda delgada e outra convexa formada por retoques diretos na parte distal, de maneira a produzir dois bordos ativos curvos, com ângulos que sugerem uma única função. Forma semelhante ao Grattoir na terminologia francesa.

MUSEU DE ARQUEOLOGIA E ETNOLOGIA DA UNIVERSIDADE DE SÃO PAULO SIITIOS LITICOS NO INTERIOR PAULISTA: UM ENFOQUE REGIONAL
Sítio Boa Esperança II

Boa Esperança do Sul, SP 


\section{PLANO DE INTERVENÇÕES ARQUEOLÓGICAS SÍTIO BES II - ETAPA 1}

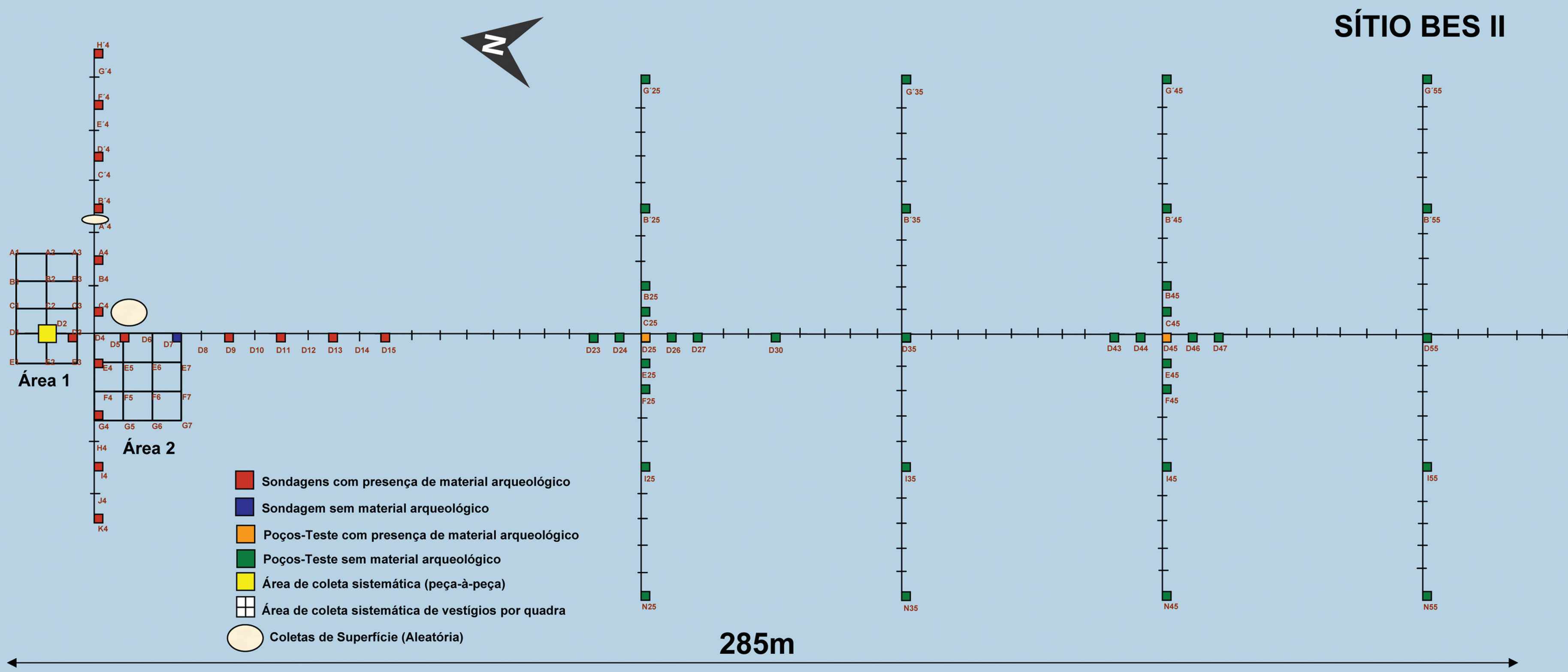

MUSEU DE ARQUEOLOGIA E ETNOLOGIA DA UNIVERSIDADE DE SÃO PAULO

SIITIOS LÍTICOS NO INTERIOR PAULISTA: UM ENFOQUE REGIONAL

Sítio Boa Esperança II ORIENTADORA 


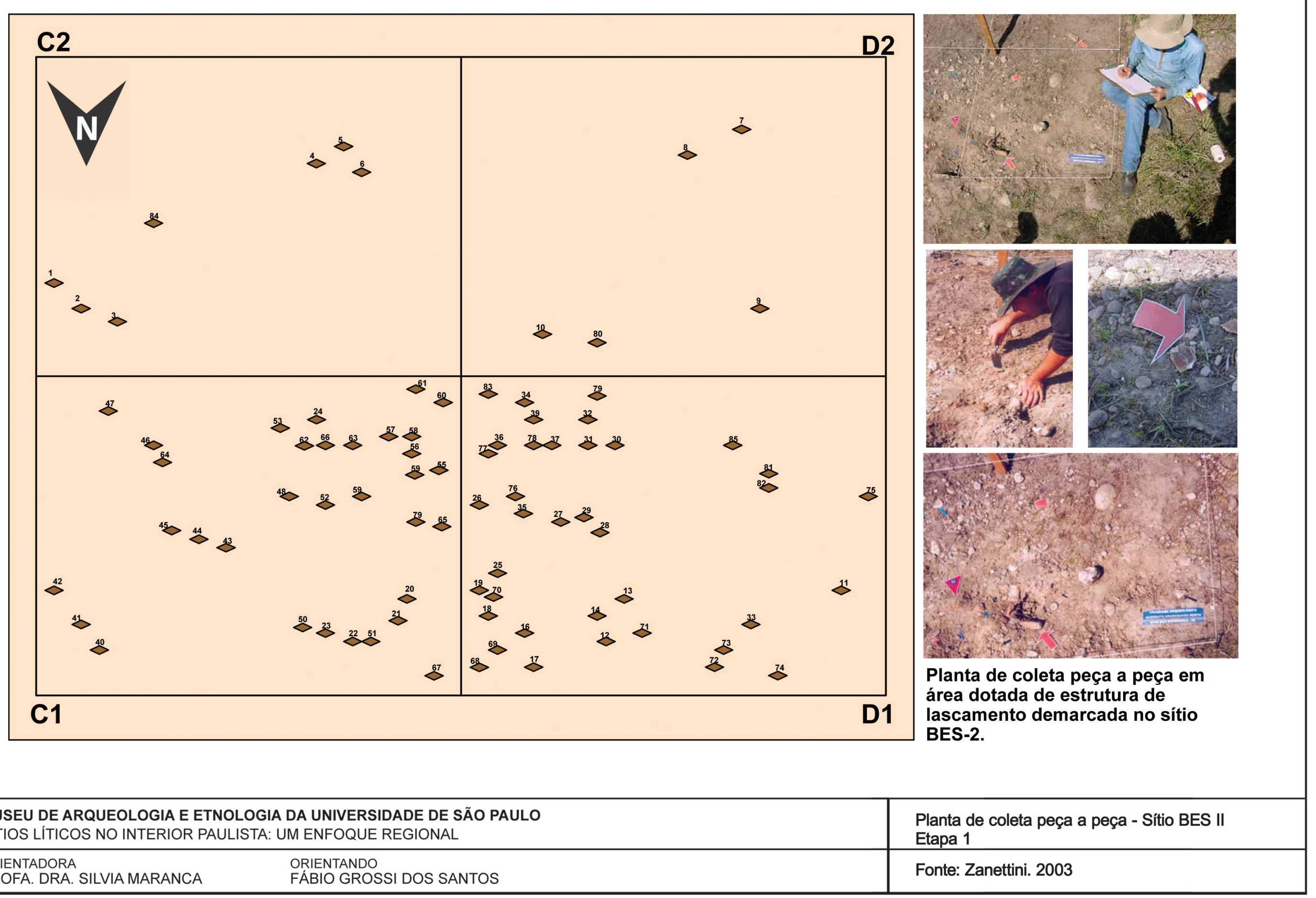




\section{SÍTIO BES II - SEGUNDA ETAPA DE CAMPO}

\section{LEGENDA:}

Unidade de escavação

Pt Sem material arqueológico

Pt Com material arqueológico

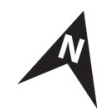

LIMITE TERRAÇO ALUVIAL

$\hookrightarrow 0,5 \mathrm{~m}$

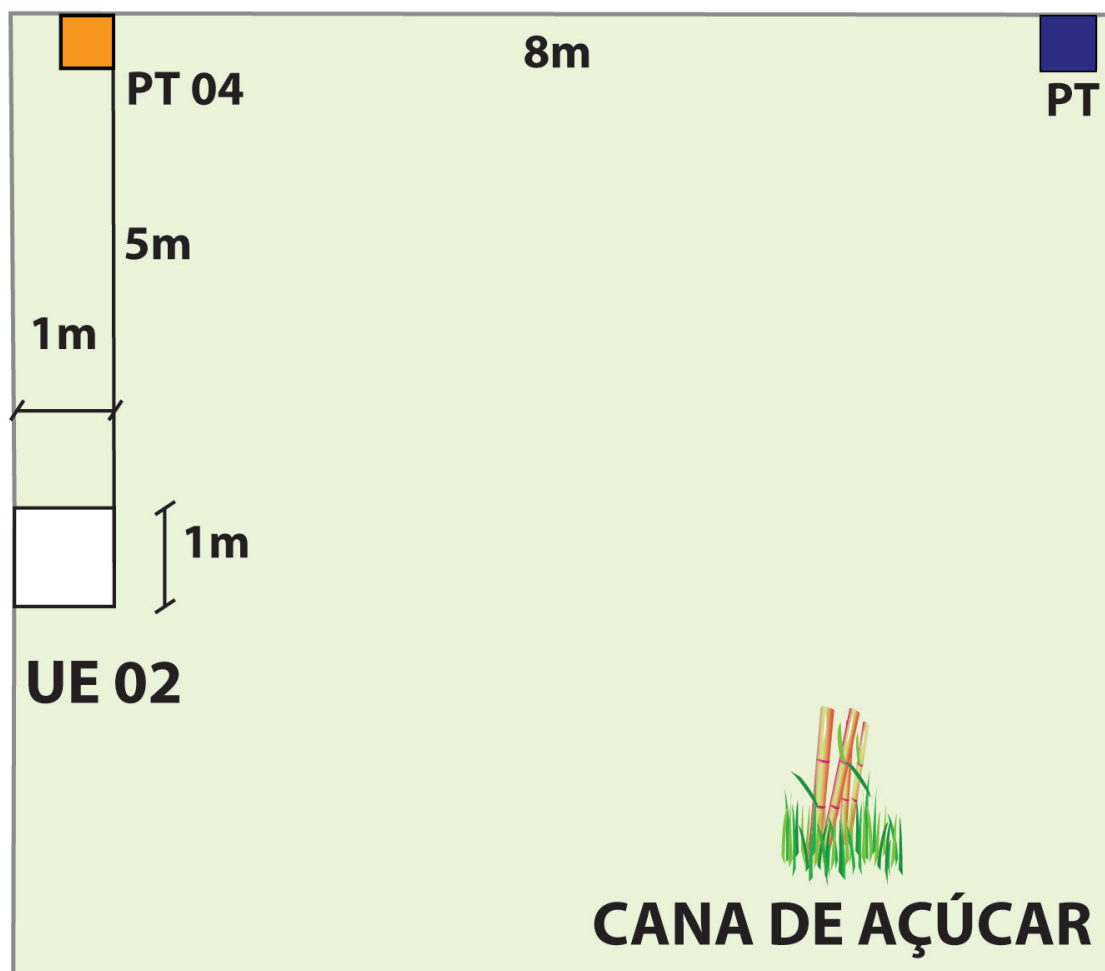

COORDENADAS EM UTM

\section{$7 m$}

PT 03

CANA DE AÇÚCAR

PT 1: 22K $0780569 / 7578479$

PT 2: 22K $0780561 / 7578484$

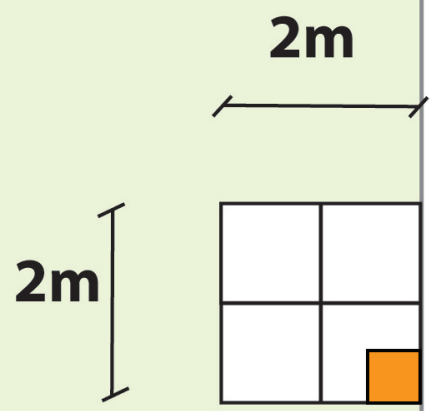

PT 4= UE 02

PT 4: 22K 0780543 / 7578492

PT 1 = UE 01 


\section{PLANO DE INTERVENÇÕES ARQUEOLÓGICAS SÍTIO BES II - ETAPAS 1 E 2}
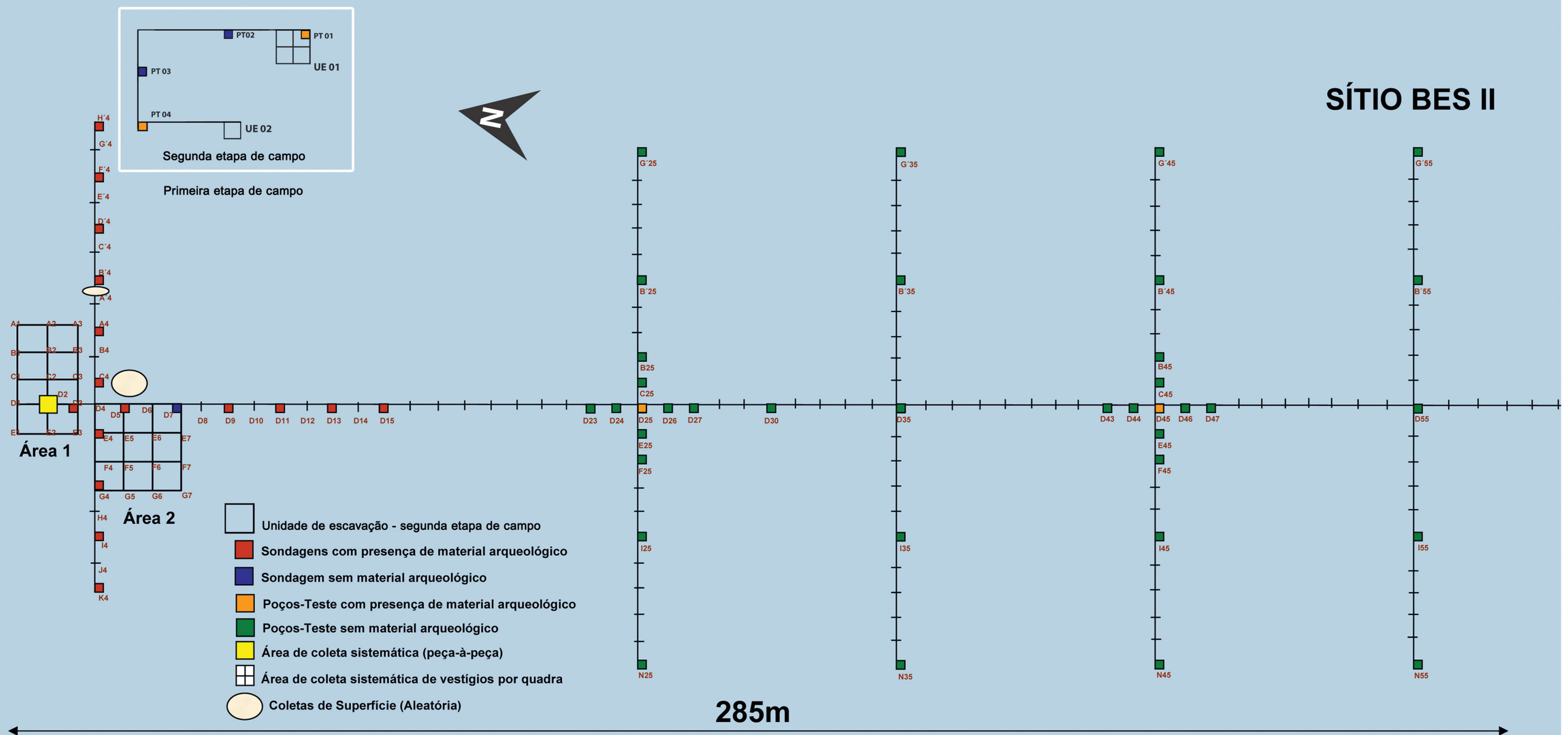

MUSEU DE ARQUEOLOGIA E ETNOLOGIA DA UNIVERSIDADE DE SÃO PAULO

SÍTIOS LÍTICOS NO INTERIOR PAULISTA: UM ENFOQUE REGIONAL

Sítio Boa Esperança II 


\section{IV.3.1) Análise Vertical}

Uma característica muito importante deste sítio, além da sua extensão horizontal, é sua profundidade. Na primeira intervenção de campo, foi encontrado material arqueológico desde a superfície até a profundidade de 1,8 m. E cabe ressaltar que não foi atingido o embasamento do solo, ou seja, não podemos precisar qual a profundidade exata do pacote arqueológico. Interessante notar que o material lítico se faz presente continuamente por todos os níveis artificiais. Como podemos notar no gráfico abaixo, percebemos maior concentração de material entre os níveis superficiais e o nível 5 (até 50 centímetros). Quanto mais profundo, menor a quantidade, porém, o material não cessa.

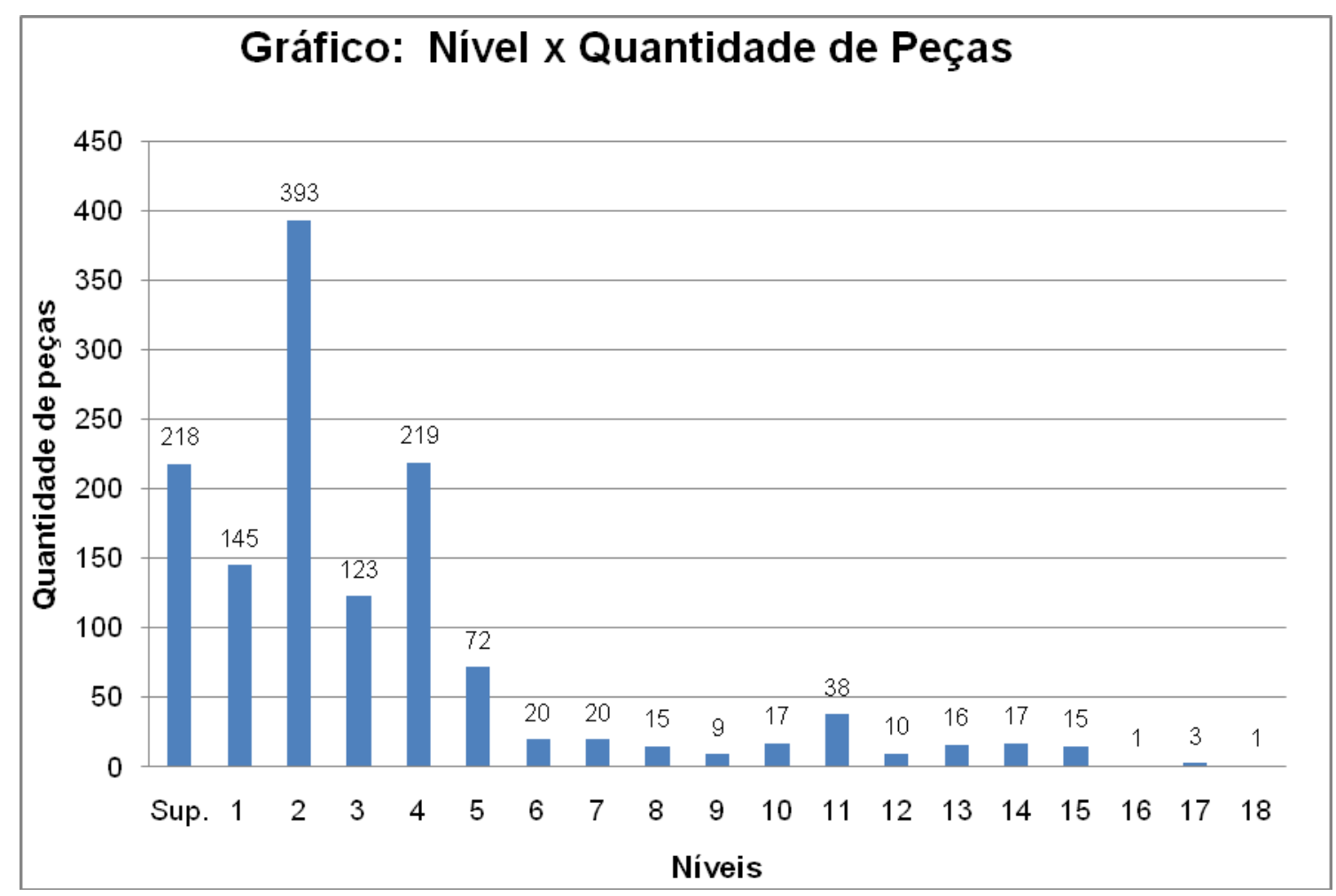

Gráfico 22: Nível x Quantidade de Peças

Na observação da variabilidade da forma de apresentação das peças, ou seja, seu suporte, percebemos que há uma constância em todos os níveis. Todos os suportes disponíveis no local foram usados em todos os momentos de ocupação do sítio, mantendose a preferência pelos seixos e nódulos. Não, ao que tudo indica, por uma escolha, mas sim, 
pela maior oferta dessa categoria. Os blocos, por exemplo, foram os menos usados, pois são exógenos.

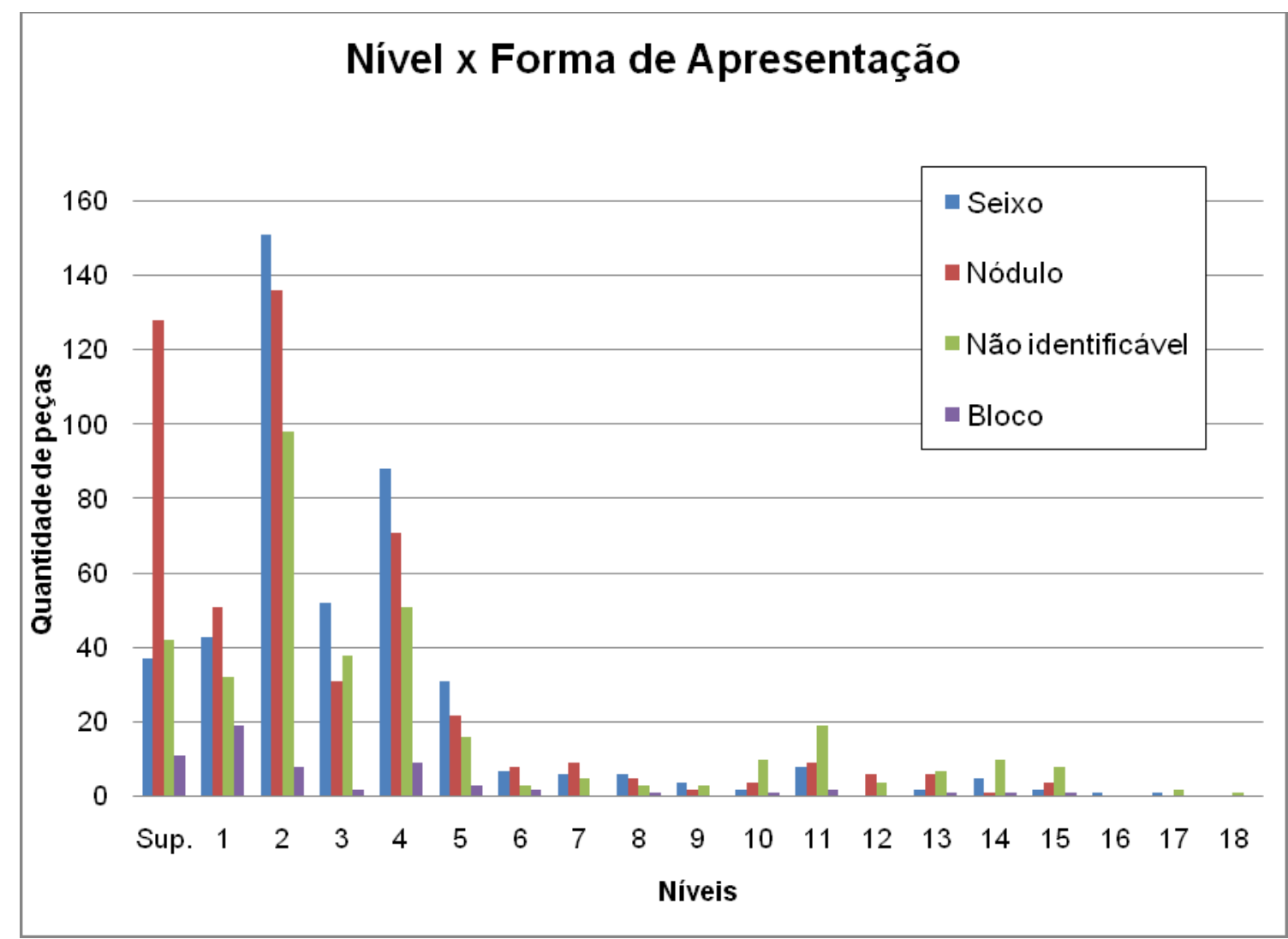

Gráfico 23: Nível x Forma de Apresentação

Basicamente, encontramos o mesmo padrão na relação dos instrumentos com os níveis. A maior concentração deles está entre os cinco primeiros níveis artificiais, com destaque para a superfície. No entanto, há incidência de instrumento nos níveis mais profundos, inclusive um deles na profundidade $1,5 \mathrm{~m}$. 


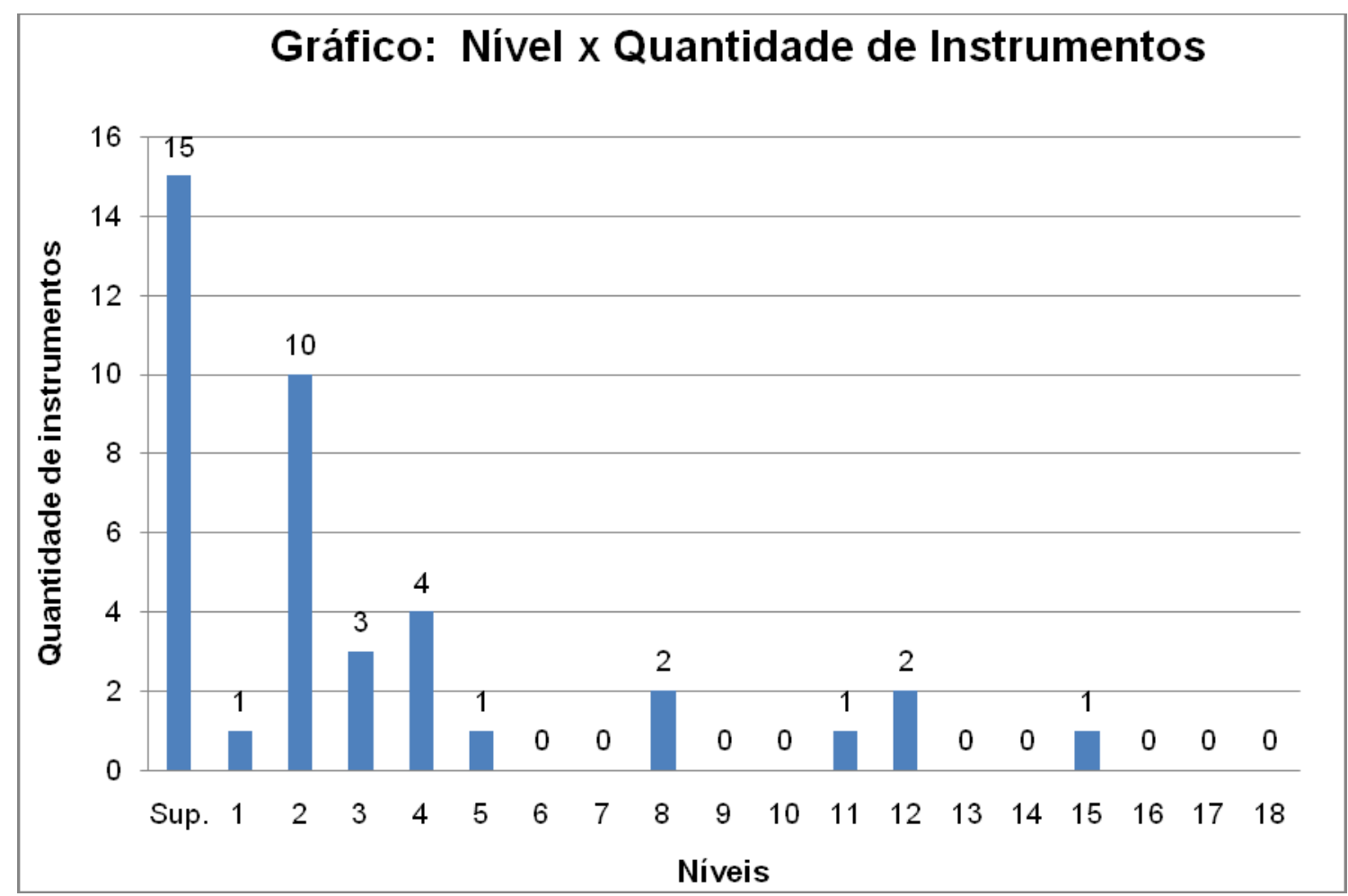

Gráfico 24: Nível x Quantidade de Instrumentos

A relação com a matéria-prima também mantém certa constância. Há presença de todas as matérias-primas identificadas em praticamente todos os níveis, prevalecendo o sílex, seguido do arenito silicificado. Em terceiro lugar está a presença do quartzo, o arenito e por fim o conglomerado. Nota-se entretanto, que quanto mais profundo há cada vez menos incidência de quartzo, e o número de sílex passa a superar o de arenito silicificado. Contudo, a prevalência do sílex, especialmente nos níveis superiores, poderia indicar uma escolha por parte do lascador, sendo que, como ressaltamos, a disponibilidade do arenito silicificado é equivalente. E essas são as duas matérias-primas, nesse contexto, com melhor aptidão para o lascamento, sendo que a melhor das duas é justamente o sílex. 


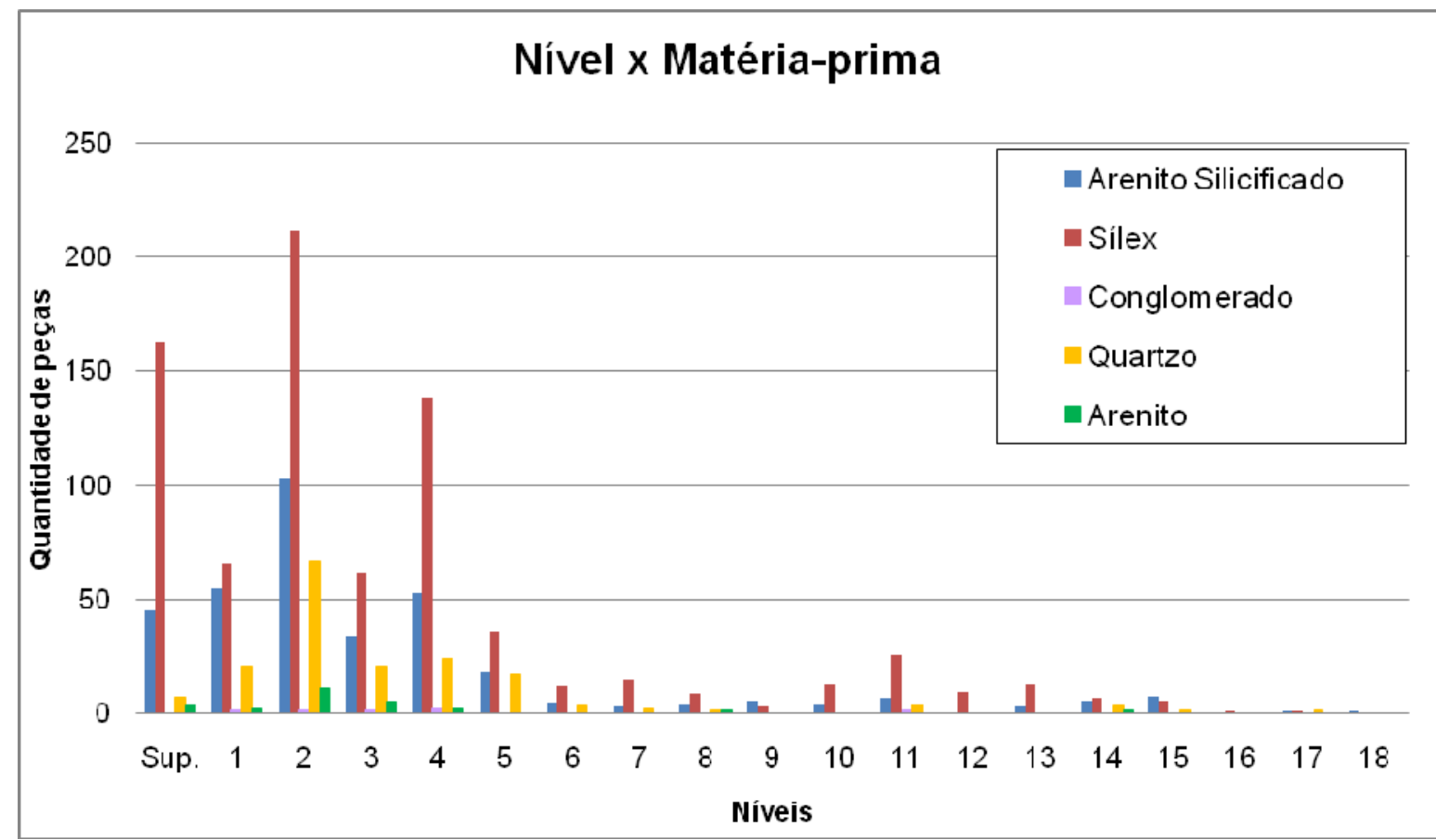

Gráfico 25: Nível x Matéria-prima

\section{IV.3.3) Estratigrafia}

Tanto nas unidades de escavação realizadas na primeira etapa de campo, em 2003, quanto nas unidades realizadas na segunda etapa, em 2010, percebemos em geral, a existência de três níveis naturais na área onde esta localizado o Sítio BES II. Existe uma primeira camada superficial, onde esta a plantação de cana-de-açúcar, marcada por uma coloração marrom-escura argilo-arenoso, com uma média de $10 \mathrm{~cm}$ de espessura. Sua coloração se deve ao fato da decomposição do material orgânico da superfície. Em seguida há uma segunda camada mais espessa, com média de 60 cm, com coloração cinza clara argilo-arenoso, ou gleissolo. Solo esse caracterizado pela proximidade com cursos d'água. Por fim, temos uma terceira camada, também de gleissolo, porém, um pouco mais escura e mais argilosa. Não sabemos sua profundidade porque o aprofundamento até o embasamento rochoso foi impossibilitado pela infiltração constante de água, porém, a escavação se deu até 1,16 metros. O que marca essa terceira camada é seu preenchimento total com seixos de pequenas e grandes dimensões, e a partir do nível artificial 7 (60 - $70 \mathrm{~cm}$ ) aumenta a intesidade dos clastos com dimensões com média entre 25 e 40 cm de comprimento.

Na unidade 02 da segunda etapa, realizada alguns metros acima da unidade 01, houve uma pequena diferença. Há nela a presença de uma segunda camada, de $10 \mathrm{~cm}$ de 
espessura, composta totalmente por seixos de pequenas dimensões, como uma "stone line". O terceiro estrato inicia o mesmo gleissolo da unidade 01. Porém, seu aprofundamento se deu somente até $80 \mathrm{~cm}$ de profundidade devido a intensa infiltração de água , que impediu a continuidade da escavação. Podemos ver essas situações nos croquis a seguir: 


\section{SÍTIO BES II - SEGUNDA ETAPA DE CAMPO}

PERFIL NORTE - CROQUI

UNIDADE ESCAVAÇÃO 01

QUADRANTE NORDESTE

\section{LEGENDA}

\section{I}

Pouco pegajoso, pouco-plástico, arenoargiloso. Presença intensa de raízes e matéria orgânica. Coloração escura com pequenas lentes cinzas claras.

\section{II}

Pouco pegajoso, não plástico, arenoargiloso. Diminuta presença de raízes e matéria orgânica. Presença de ferricretes, os quais possuem ao menos 2 eventos de oxidação envovidos em sua gênese. Coloração cinza clara.

\section{III}

Presença massiva de cascalhos de conglomerado inconsolidado. Clastos heterogêneos na composição - argilitos, siltitos, basaltos, arenitos e silex - e formas - variação de esférica a oblata - mas homogêneos em grau de arredondamento - muito bem arredondados - e na ausência de marcas de choques. Heterogenidade também presente no diâmetro - variação média entre 5 a $20 \mathrm{~cm}$, com maiores na casa dos 30 e $40 \mathrm{~cm}$.

X Raizes

$88_{0}^{\circ}$ Clastos pequenos

Clastos grandes

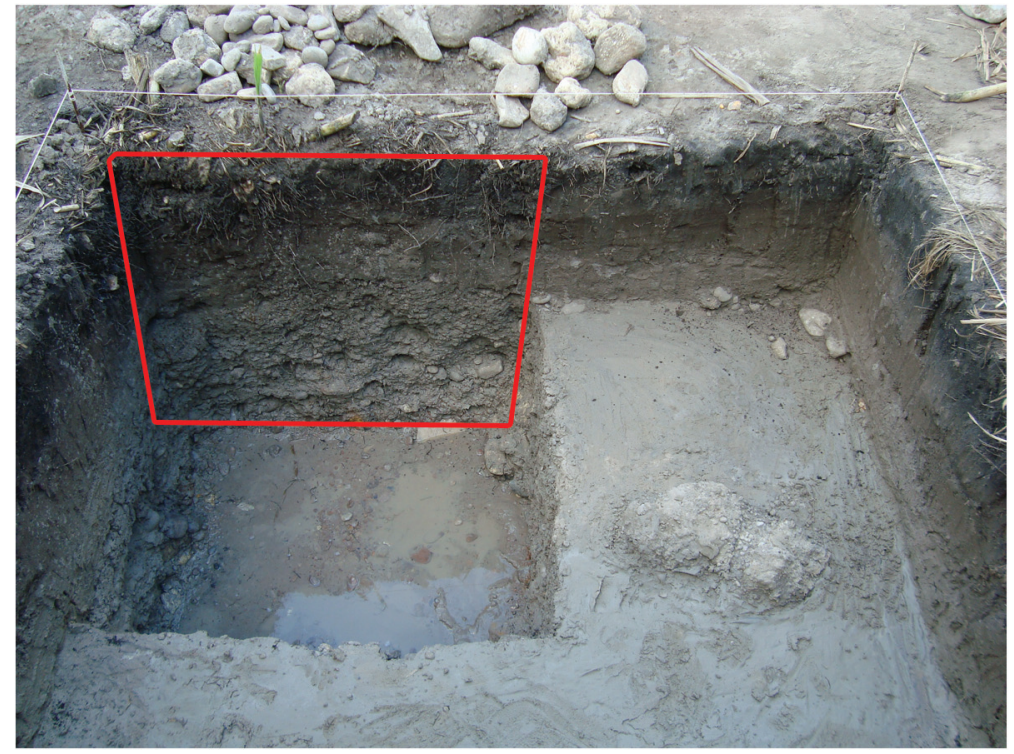

$100 \mathrm{~cm}$
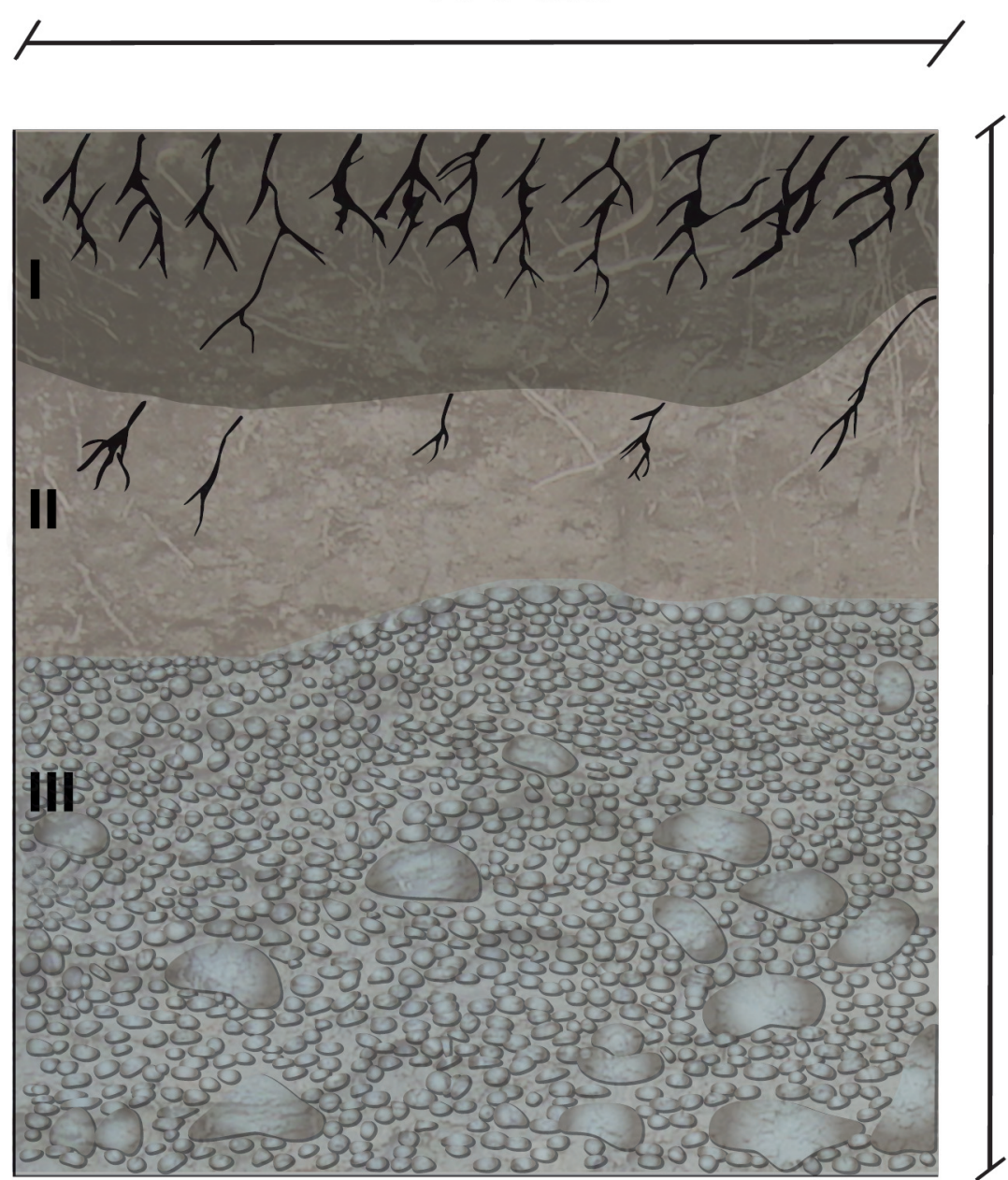


\section{SÍTIO BES II - SEGUNDA ETAPA DE CAMPO}

PERFIL OESTE - CROQUI

UNIDADE ESCAVAÇÃO 02

\section{LEGENDA}

\section{I}

Pouco pegajoso, não plástico, arenoargiloso. Coloração escura. Presença intensa de raízes e matéria orgânica.

\section{II}

Presença massiva de cascalhos de conglomerado inconsolidado. Heterogêneo na composição - basaltos, argilitos, siltitos e basaltos - e na forma - variação de esférica a oblata - mas homgêneo no arredondamento muito bem arredondados - e na ausência de marcas de choques. Variação de diâmetro entre entre 2 e $4 \mathrm{~cm}$, com maiores na casa dos $10 \mathrm{~cm}$.

\section{III}

Pouco pegajoso, pouco plástico, arenoarginoloso. Diminuta presença de raízes. Coloração cinza.

1. Raizes

$88_{0}^{\circ}$ Clastos pequenos

Clastos grandes
08 FEV 2010

FÁBIO GROSSI

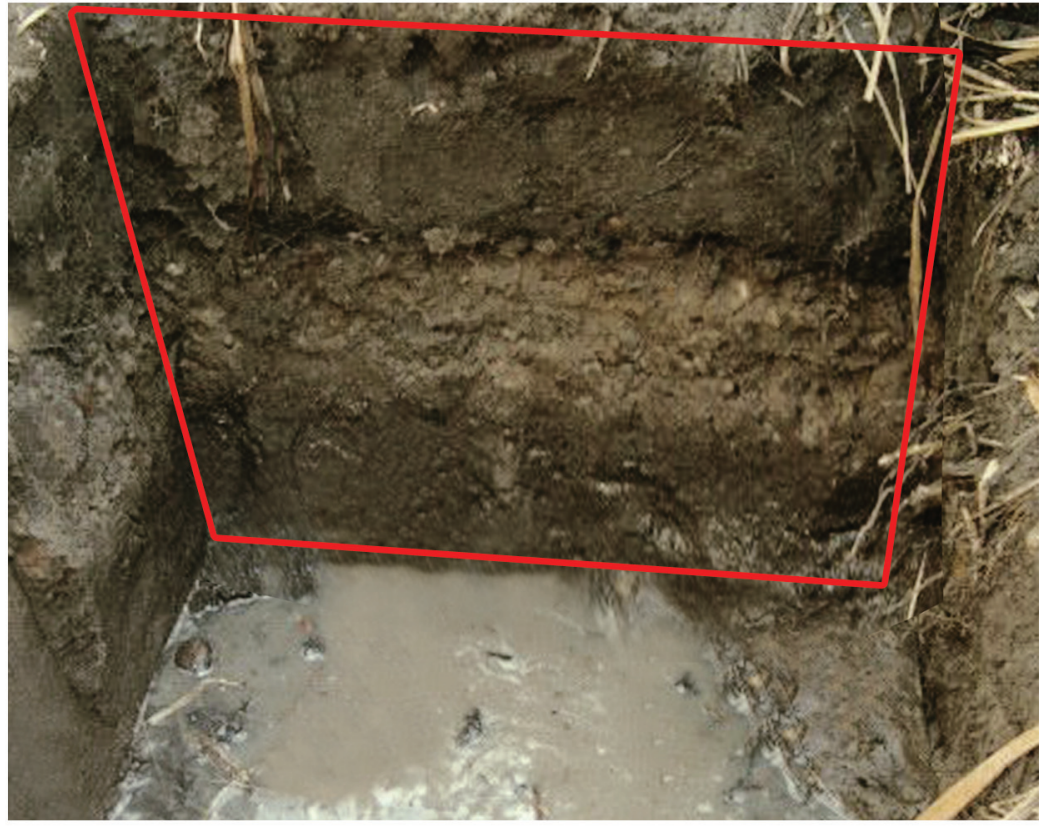

$100 \mathrm{~cm}$
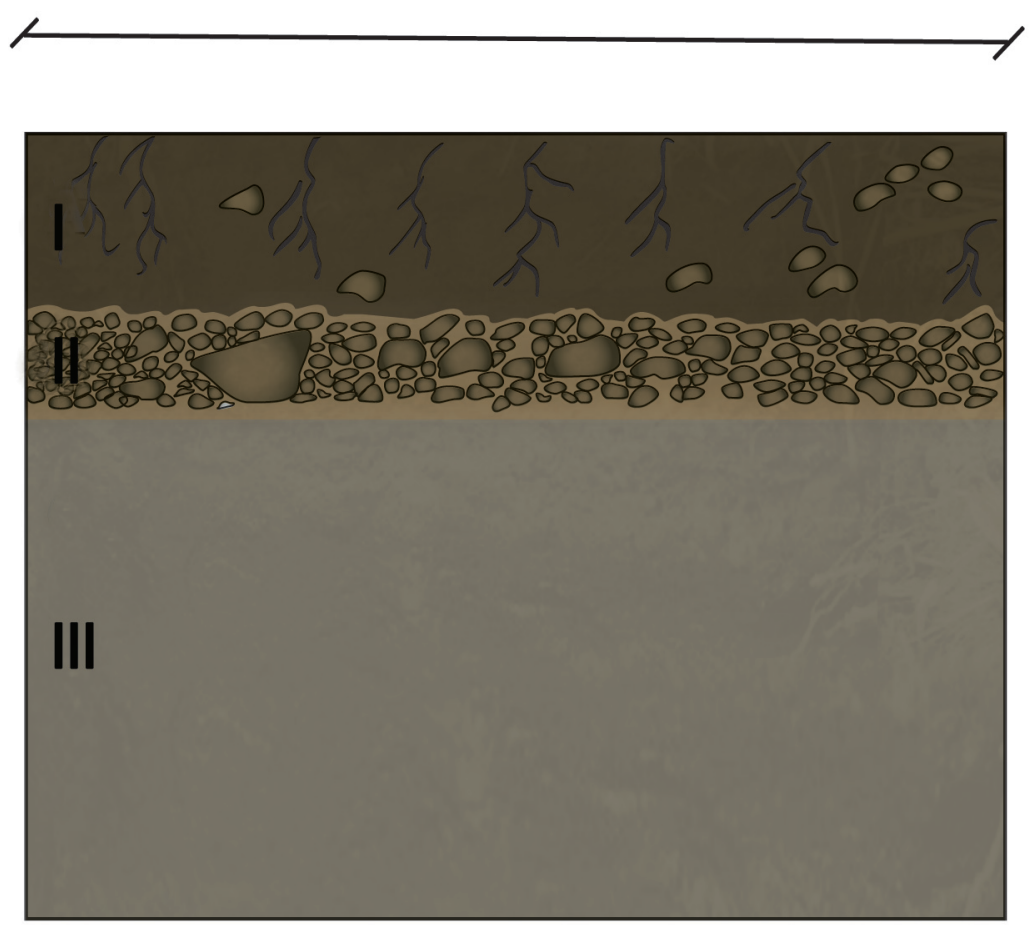

$19 \mathrm{~cm}$

$8 \mathrm{~cm}$

$53 \mathrm{~cm}$ 


\section{3.4) Cronologia}

Como já foi mencionado no capítulo dos métodos, na segunda intervenção arqueológica realizada em Fevereiro de 2010, foi coletada uma amostra de sedimento para fazer datação por Luminescência oticamente estimulada. A amostra foi coletada entre os níveis artificiais 6 e 7 (60 e 70 centimetros), pois foi a profundidade com maior incidência de material na unidade de escavação aberta no limite do terraço aluvial.

A datação realizada por LOE no Sítio BES II registrou a data de 14.500 +- 3.000 anos antes do presente. Mesmo considerando a variação de 3.000 anos, ainda é uma data pleistocênica, o que indicaria a ocupação desse local por grupos paleoíndios, que conviveram em outro ambiente - outros animais (a megafauna), outra flora, outro clima. Essa faixa de idade no Brasil é muito rara, havendo no Estado de São Paulo apenas poucas datas entre 8 e 9 mil anos, uma de 11 mil e outra de 14 mil - o Sítio Alice Boër - em Rio Claro, que não é aceita devido a dúvida sobre o carvão datado ser realmente do nível arqueológico, além da bioturbação. E para o contexto americano, uma antiguidade dessas entraria na polêmica questão do Povoamento do Continente. Por isso mesmo, essa data obtida para o sítio BES II fica mais como um instigante para futuras pesquisas e termômetro para mostrar a riqueza do assentamento que estamos tratando. Os trabalhos vindouros irão comprovar sua idade, ou não.

\section{IV.3.2) Análise de dados}

Pelo que foi aqui exposto, o Sítio BES II sugere de imediato uma intensa atividade de grupos caçadores-coletores nessa porção da região araraquarense e do mesmo modo, um grande potencial para o exame de sub-sistemas que integram os chamados grandes sistemas regionais da região Sudeste do Brasil, que tem no Noroeste do Estado de São Paulo uma de suas zonas de transição e fronteiras (Morais 2000). Tal idéia hoje se encontra como foco de

discussão, contudo, aponta para a grande diversidade na cultura material dos povos que habitaram o Estado. 
Sobre a aquisição da matéria-prima, está claro nesse caso que a implantação do sítio está diretamente relacionada à facilidade de obtenção dos recursos necessários para o lascamento.

Do ponto de vista espacial, também se evidencia que os grupos humanos que nesse local se instalaram se valeram amplamente dos recursos oferecidos por essa zona ecológica de transição, explorando intensamente todos os compartimentos da paisagem ali presentes, desde o vales adjacentes aos cursos d’água até as altas vertentes que o conformam, sobretudo, a Oeste.

A situação do Sítio Boa Esperança II, por sua vez, nos sugere a clara necessidade de se promover uma ampla revisão dos modelos etnográficos e analogias usualmente adotadas na explanação de fenômenos culturais relacionados à constituição, organização, dimensionamento e mobilidade dos grupos caçadores-coletores, nos acenando certamente para índices populacionais significativamente maiores, bem como o tempo de manutenção e exploração de uma determinada região por grupos seminômades, durante longos períodos. Isso indica uma menor mobilidade, o que acaba exigindo, obviamente, estudos ecológicos que contribuam para um melhor entendimento de aspectos de sazonalidade que possam ter influenciado o comportamento e deslocamento/assentamento/manutenção. Do mesmo modo, torna-se indispensável a intensificação das análises inter sítios (Zanettini, 2003).

A profundidade e constância do material arqueológico indica não só esse maior número populacional e “seminomadismo”, como também mostra o grande aproveitamento da área por longo período de tempo. Seria necessário obter datações por todos os níveis arqueológicos detectados para se afirmar com precisão o intervalo real de ocupação desse sítio. Entretanto, pelas características apontadas, podemos inferir que foi um longo período, mostrando que os grupos que lá estiveram se valeram de um local adequado para se instalar; uma habitação, que fornecia alimentação e abrigo. Trata-se, portanto, de um sítio habitação, nuclear, com possíveis sítios menores no perímetro de uma área estabelecida como território desses habitantes, o que Paula Dantas de Blasis chama de "sítios satélites” (1988). A indústria lítica também denuncia, quando suas formas e funcionalidades apontam para uma maior variedade de atividades, como raspar, cortar, furar e bater. Outra pergunta que se faz diante das informações obtidas é se essa ocupação contínua se trata de um mesmo horizonte cultural ou se seriam ocupações sucessivas de grupos distintos. A 
variabilidade da indústria lítica precisa ser passível de análise mais apurada para se verificar se há continuidade cultural. Notamos, contudo, um gradativo aumento populacional. Percebemos nos níveis mais profundos pouca incidência de material arqueológico, e o seu aumento considerável nos níveis superiores. De qualquer maneira, ao que parece, as características desse material pouco mudam, havendo pouca diferença na confecção de instrumentos. O diferencial nesse quesito se faz presente, não só pela quantidade detectada, mas também no acabamento de alguns poucos instrumentos que se tornam mais trabalhados - mesmo que não atinjam um nível de padronização - nos níveis superiores, especialmente em superfície. Frisamos, entretanto, que é um número reduzido dessa categoria.

Essa mudança poderia ser explicada pelo aumento populacional que se evidencia. Com uma população pequena os instrumentos simples refletem a atividades imediatas, de cunho prático, que tendem a atender um fim específico, como o descarne de uma caça por exemplo. Feito seu intento, o lascador descartaria sua ferramenta, pois fabricaria outra mais tarde quando precisasse, devido à grande oferta de mataria-prima. Ou então, se valendo de sua mobilidade, levaria o instrumento consigo. Com o aumento populacional, sua mobilidade diminui, dessa forma, o tempo que ele gastaria em seus deslocamentos, ele pode direcionar para a confecção de ferramentas, e isso ocasionará em um maior cuidado em seu preparo, não somente por sua forma e estética, mas também para conseguir maior aproveitamento da peça. Essas idéias, entretanto, são conjecturas, sendo necessárias mais informações sobre sítios da região e estudos intra-sítios para se poder manter tal afirmação.

\section{IV.4) Sítio Boa Esperança III (BES III)}

Foram coletadas 429 peças no sítio, sendo 90 em superfície e 339 na unidade de escavação. As características do material coletado em sub-superfície são as mesmas do material de superfície. Foram coletadas 234 lascas unipolares, 08 núcleos unipolares - 03 com possíveis marcas de reutilização -, 19 instrumentos, 131 detritos de lascamento e 39 fragmentos de lasca. 


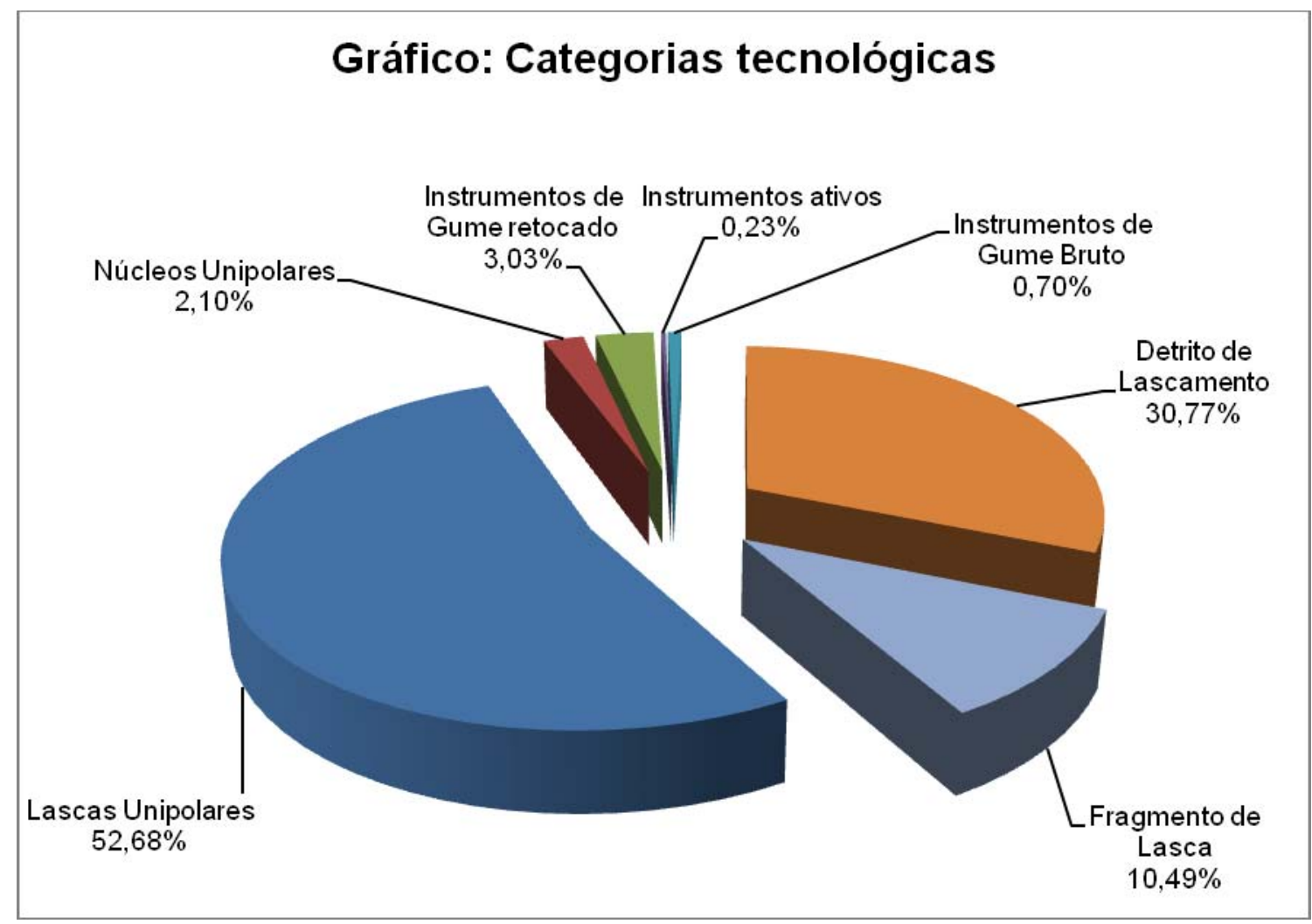

Gráfico 26: categorias tecnológicas

Como destacado anteriormente, este sítio está implantado em área de afloramento rochoso de arenito silicificado, o que acabou definindo a totalidade da matéria-prima (100\%) de seu material arqueológico, assim como o suporte utilizado, que se deu sobre blocos (em todas as peças onde o suporte foi identificável).

Ainda pode se perceber desse material que 41 peças apresentou algum tipo de alteração térmica, evidenciada por manchas negras e maior brilho.

A abundância de arenito silicificado proporcionou uma indústria baseada na obtenção de lascas grandes - entre 10 e 15 cm - (gráfico 27). A categoria mais representativa da coleção é a das lascas unipolares com 234 exemplares, sendo 15 fragmentadas. 


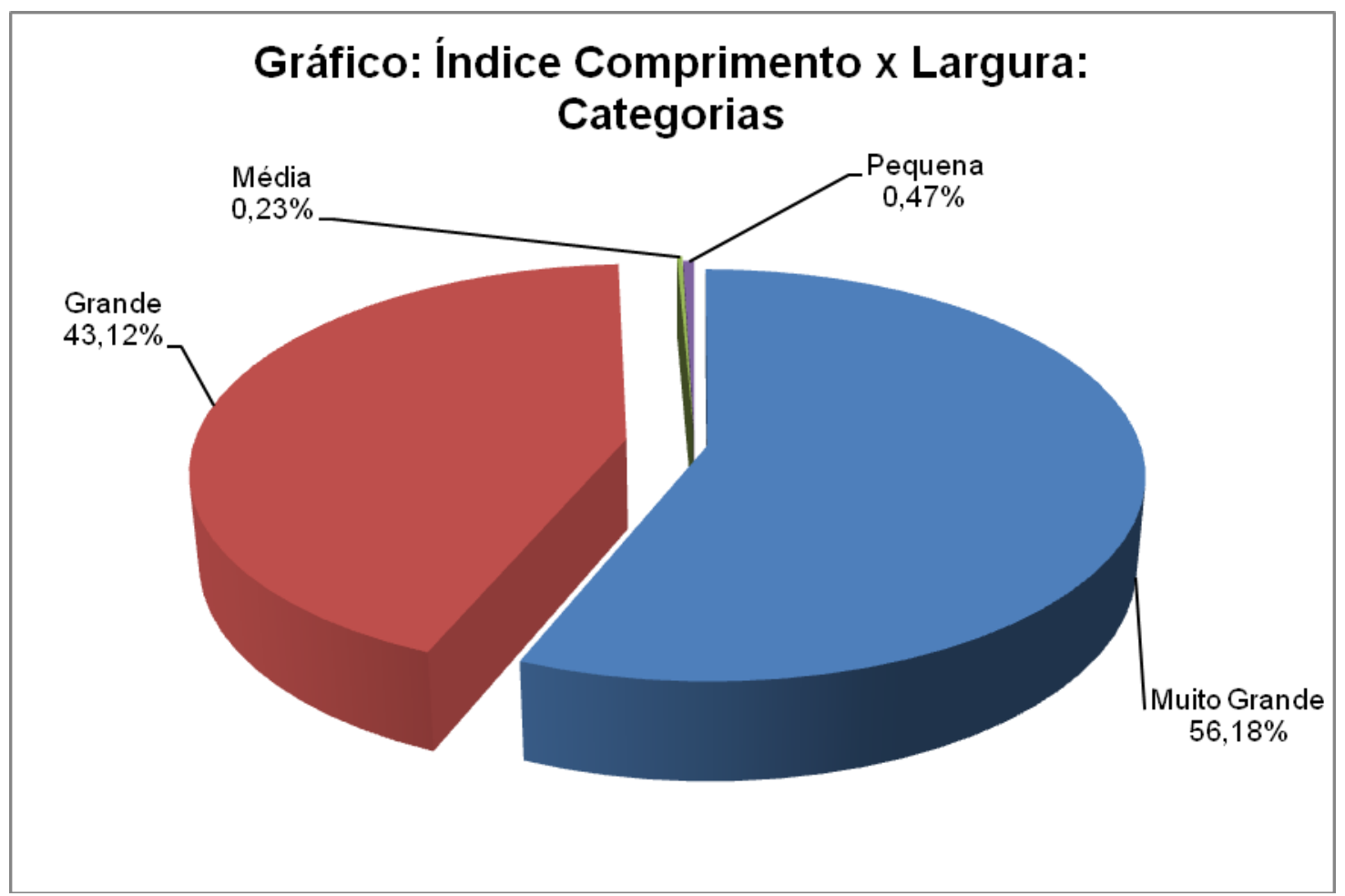

\section{Gráfico 27: Índice Comprimento x Largura}

Nesse sítio também está bem clara a importância da matéria-prima disponível nas proximidades do sítio; o arenito silicificado constitui a totalidade da coleção, assim como o suporte, que evidencia a predominância dos blocos disponíveis próximos ao sítio. A maioria das peças com córtex evidencia a utilização desses clastos.

Predominam as lascas sem córtex, o que da mesma maneira dos dois sítios já analisados, mostra um grande aproveitamento de suportes grandes, no caso, de blocos, que permitiram um alto nível de formatação das peças. Temos dessa maneira, núcleos grandes, com as medidas entre $75 \mathrm{~mm}$ para a altura; $102 \mathrm{~mm}$ para a largura e $70 \mathrm{~mm}$ para a espessura. 


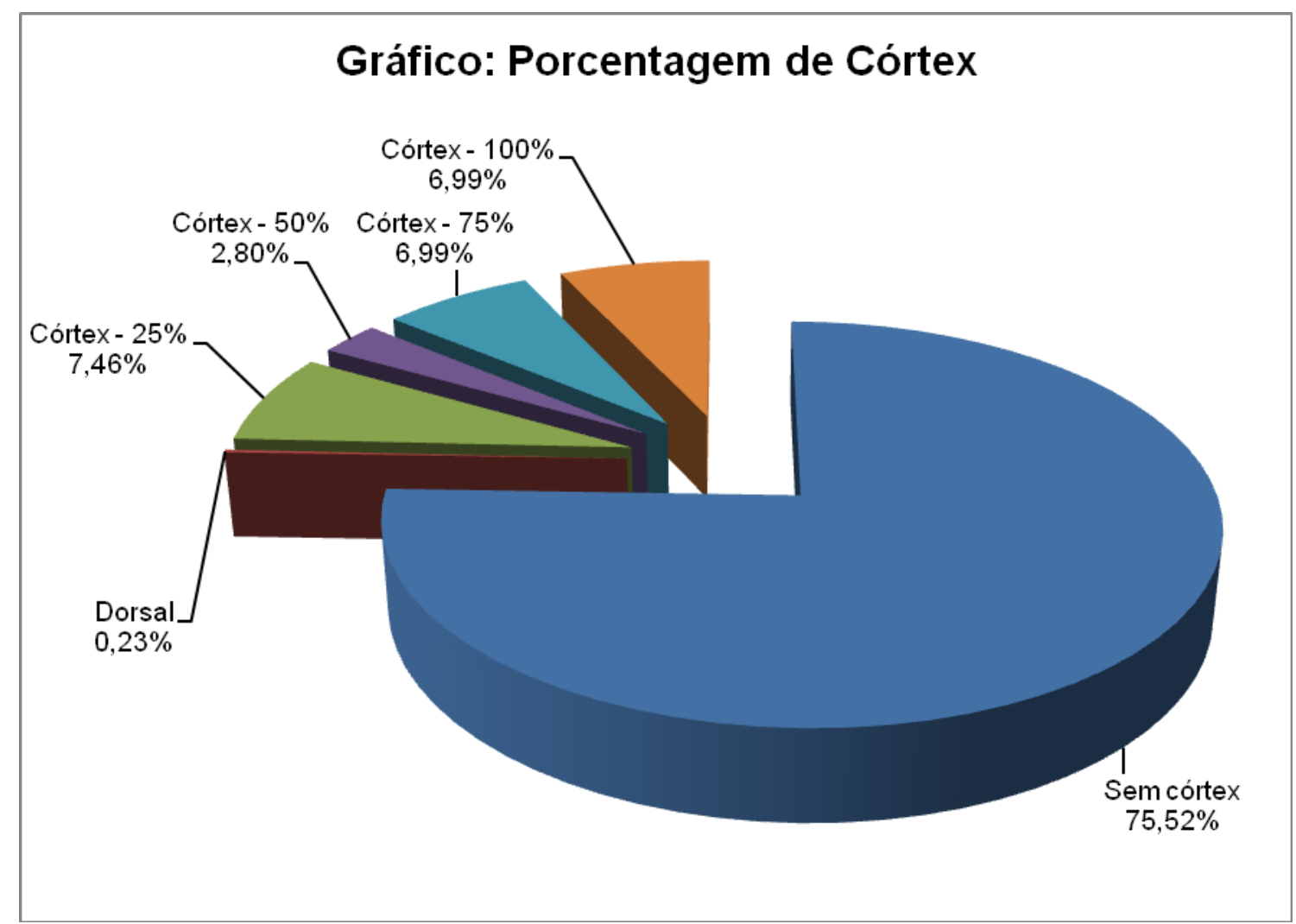

Gráfico 28: Porcentagem de córtex na face externa

Sobre a morfologia dos talões, há predominância para os talões lisos, o que, mantendo a concordância com os sítios Dois Córregos e BES II, nos indica a falta de cuidado com a preparação de plano de percussão dos núcleos. O Cruzamento dos dados dos talões com os planos de percussão dos núcleos mostram que a amostragem confirma essa tendência. 


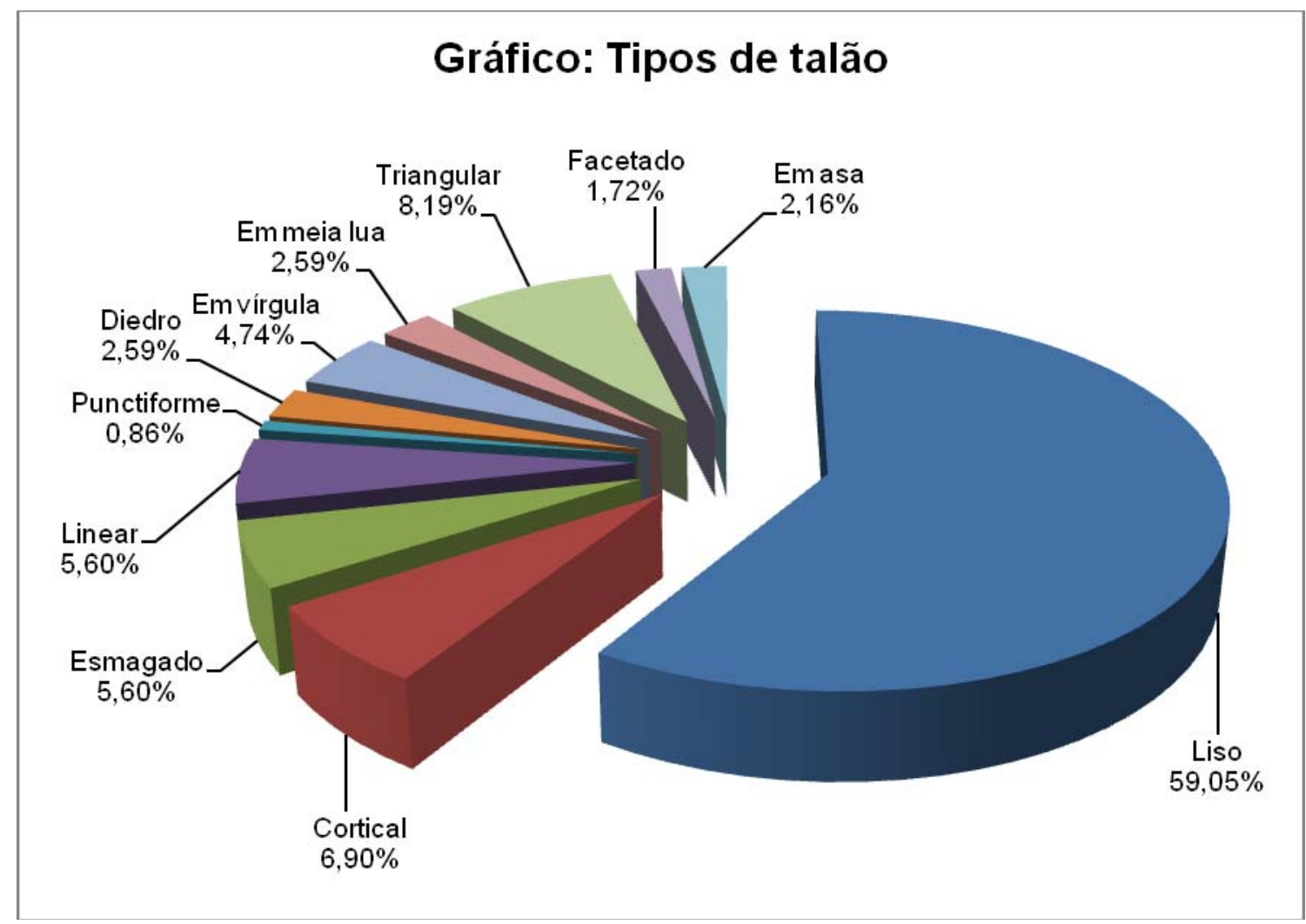

Gráfico 29: Tipos de Talão

A morfologia das lascas é bem variada, e assim, da mesma forma dos outros dois sítios em análise, a comparação dos dados nos leva a suposição de que não havia um planejamento muito padronizado do módulo do suporte a ser retocado. Os núcleos do sítio BES III também não apresentam seqüências de lascamento organizadas, os instrumentos não são uniformes e não há padronização morfológica das lascas retiradas. Repete-se a afirmativa de que, pelo fato dos suportes terem dimensões adequadas e a qualidade da matéria-prima ser boa, eles eram aproveitados independente da forma. 


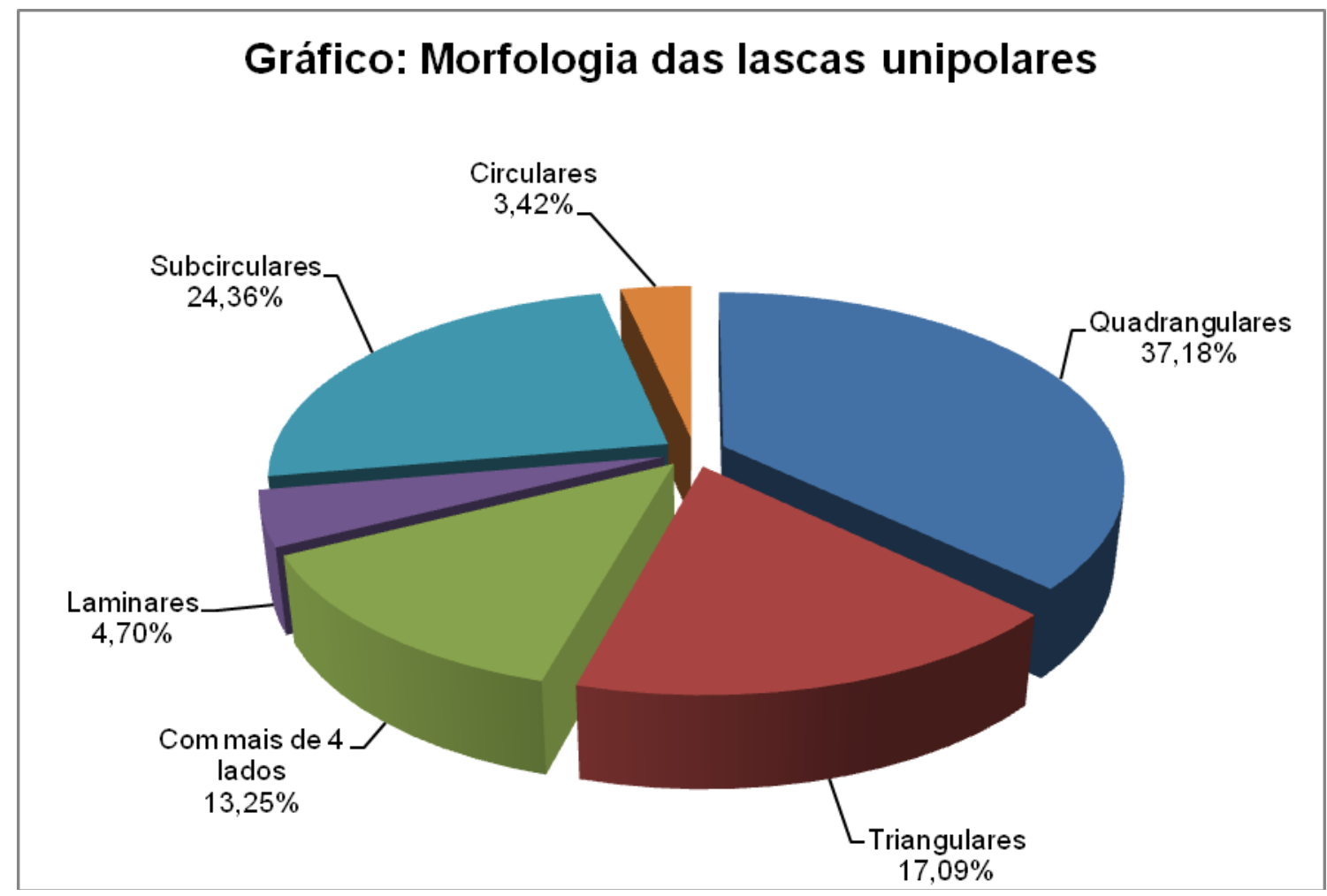

Gráfico 30: Morfologia das Lascas unipolares

Os acidentes de lascamento foram verificados em $29 \%$ das lascas analisadas. Predomina a ocorrência de ultrapassantes, seguidas pelas lascas transbordantes, refletidas, com lingüeta e sirets. Os sirets e refletidas são representados principalmente por peças de arenito silicificado de qualidade inferior. 


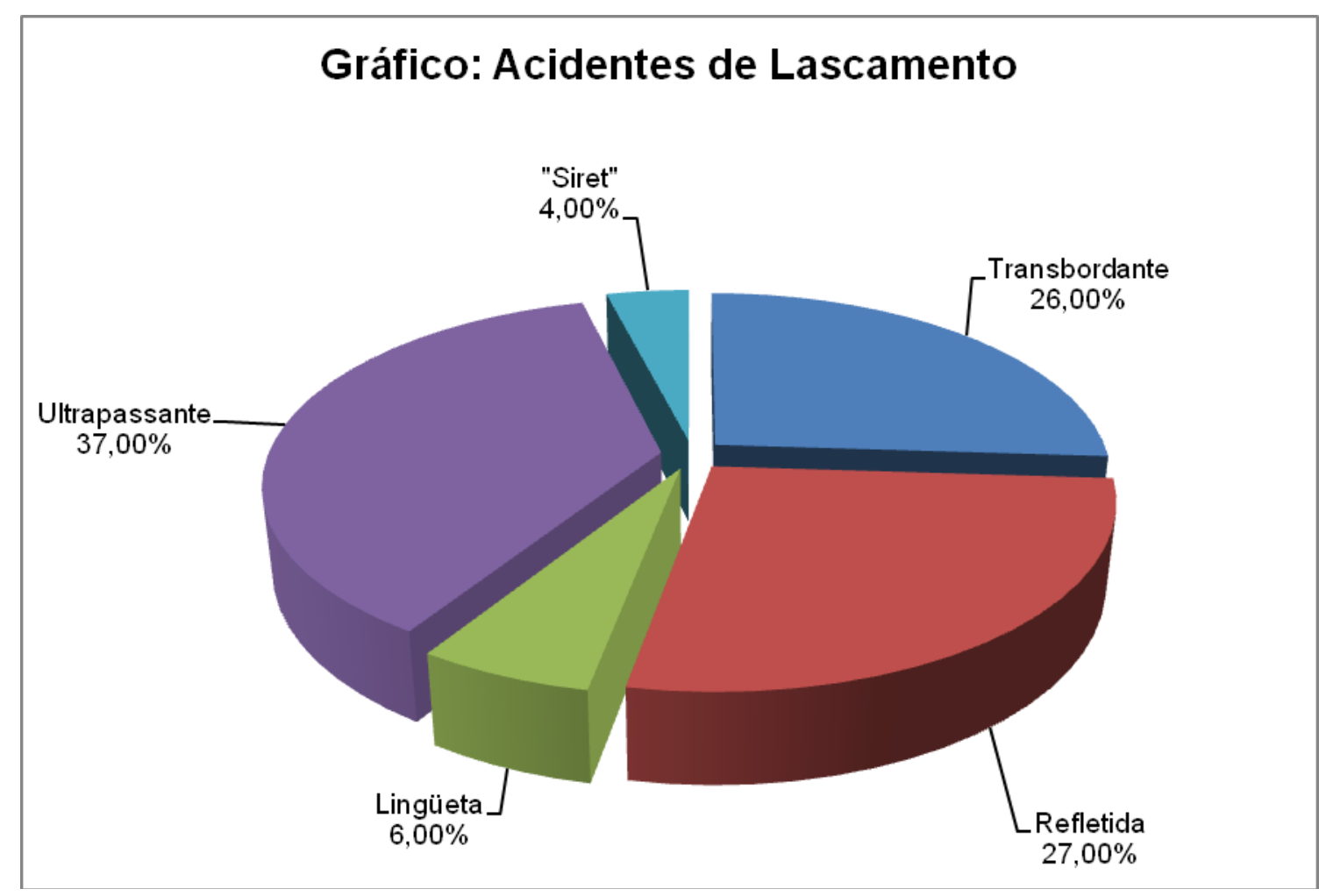

Gráfico 31: Acidentes de Lascamento

Quanto à cadeia operatória da confecção dos instrumentos, podemos perceber que seguiram na maior parte dos casos a seguinte seqüência: suporte selecionado > destacamento da lasca > retoques > abandono. Contudo, devemos destacar ao observar a cadeia operatória para este sítio, a ausência de percutores. O sítio esta implantado sobre uma fonte de matéria-prima, ou seja, os lascadores se aproveitaram dessa característica da paisagem como um dos motivos para nesse lugar se instalarem. Daí, retiraram o material para a confecção de suas ferramentas. Nesse sentido, encontramos o início da cadeia operatória até o seu final, com o descarte da peça. Entretanto, o fato dessa categoria de instrumentos não estar presente no material coletado, mostra uma característica curiosa. Isso pode levar a algumas suposições.

Considerando que o sítio BES III faça parte de um sistema de sítios, podemos supor que os percutores possam ter sido trazidos de outro local, usados para seu fim e levados embora. Afinal, na área predominam os blocos, que normalmente não são usados para esse objetivo - e não parecem ter sido usados mesmo, pois não foram encontradas marcas em peça alguma que indicasse essa atividade; diferente do que aconteceu no Sítio Dois 
Córregos -, e por esse motivo, o(s) grupo(s) que por ali passaram podem ter usado uma estratégia de economia, carregando esse instrumento consigo, sendo que sua oferta local era baixa.

Dos 19 utensílios coletados, 13 são instrumentos de gume retocado, sendo 6 com suporte sobre lasca e 7 com suporte sobre bloco - um deles apresentando coche (reentrância); 4 de gume bruto com suporte sobre lasca, inteiros ou fragmentados, retocados unifacialmente, e novamente destacando, principalmente produzidos sobre lascas grandes. Também há um instrumento sobre núcleo e um puntiforme sobre fragmento de lasca, este último, denominado nessa análise como instrumento ativo. A média das medidas está entre $100 \mathrm{~mm}$ para o comprimento; $60 \mathrm{~mm}$ para a largura e $25 \mathrm{~mm}$ para a espessura.

Do total dos instrumentos coletados, nota-se ainda, que a maioria deles possui entre 1 e 2 bordos ativos. Sendo que 5 possuem 1 bordo e 7 possuem 2 bordos ativos, como podemos ver no gráfico abaixo:

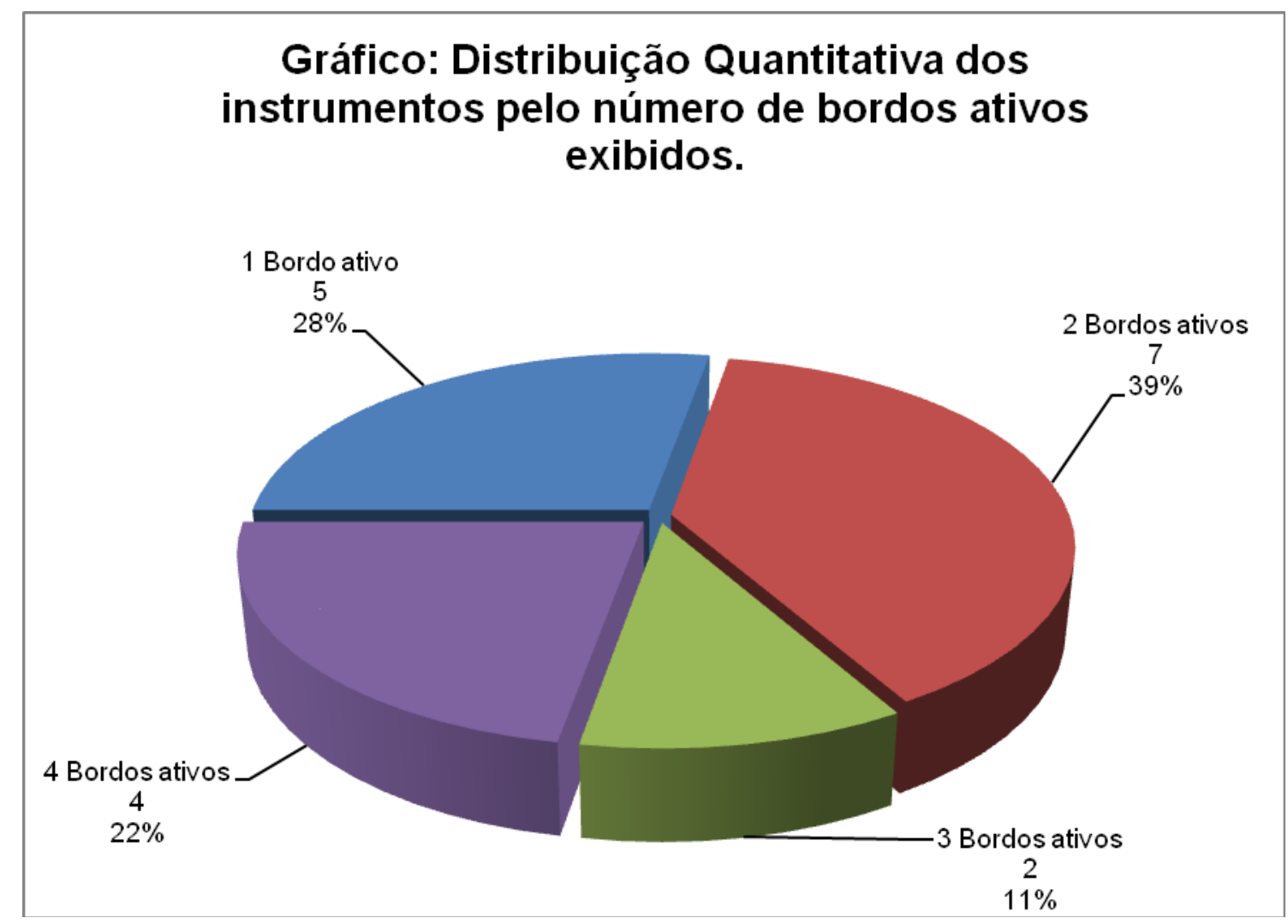

Gráfico 32: Distribuição quantitativa dos utensílios pelo número de bordos ativos exibido 
Sobre os ângulos dos bordos ativos dos instrumentos, a análise evidencia a predominância dos ângulos entre $50^{\circ}$ e $60^{\circ}$, seguido dos ângulos de $40^{\circ}$ e a média entre $80^{\circ}$ e $65^{\circ}$. A minoria possui ângulos rasantes. Isso nos indica a funcionalidade para raspagem desses utensílios, o que destaca atividades mais restritas para esse sítio.

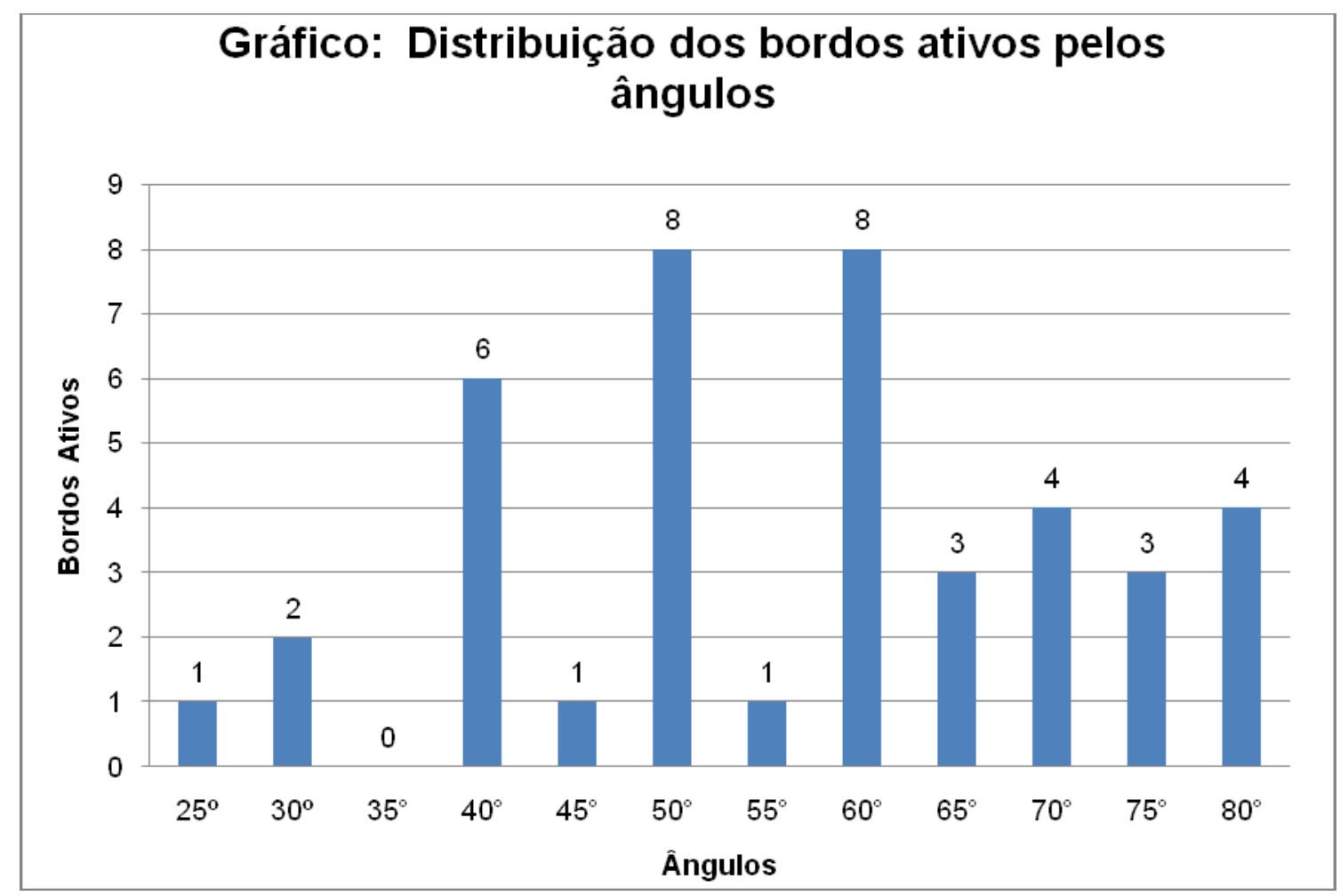

Gráfico 33: Distribuição dos bordos ativos pelos ângulos

A descrição um pouco mais detalhada dos instrumentos do sítio BES III pode ser vista nas pranchas apresentadas a seguir, com a ilustração das peças consideradas mais representativas da coleção. 

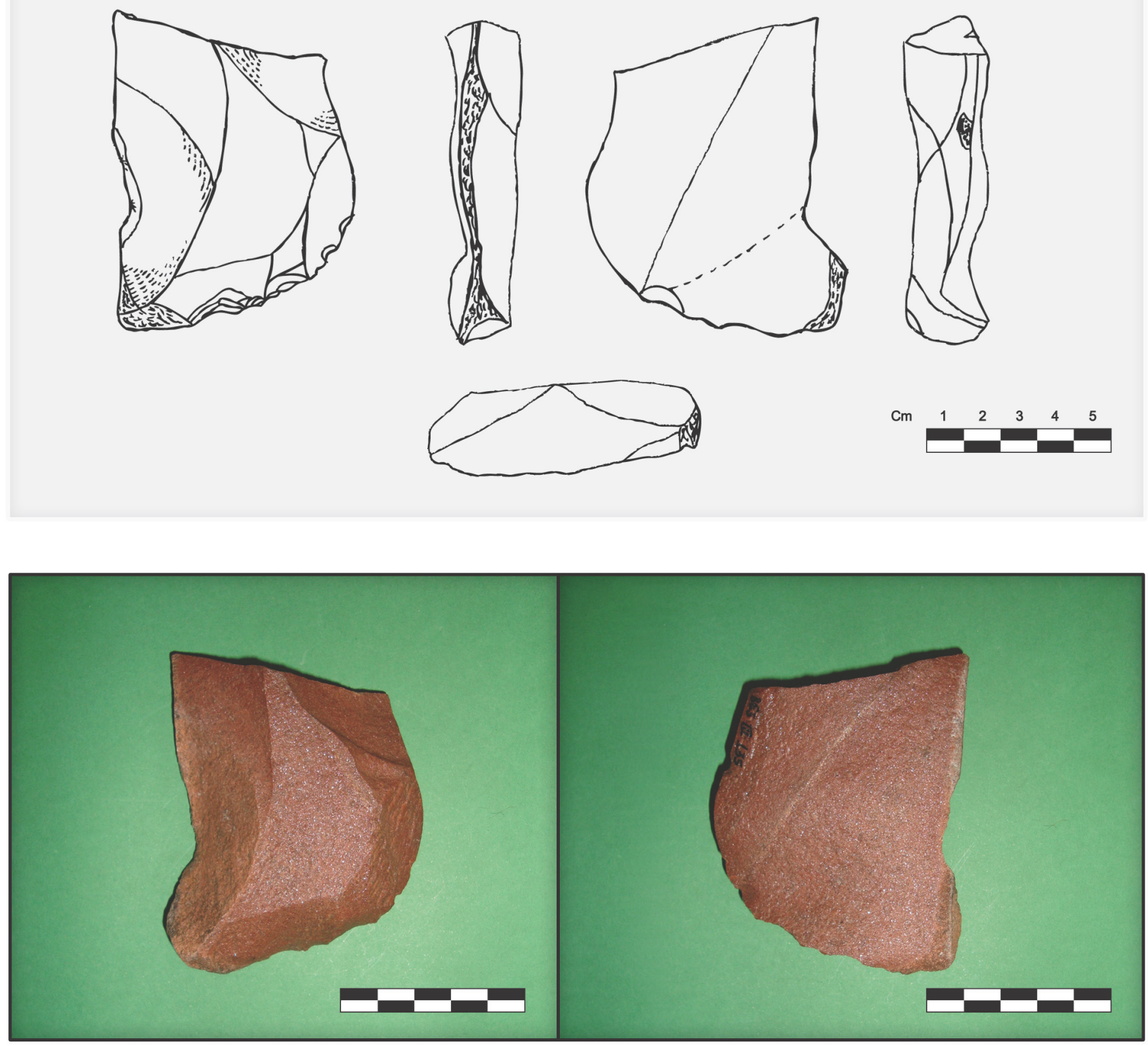

PEÇA BES III 135

Instrumento informal sobre fragmento de lasca unipolar

BORDOS ATIVOS: $2-60^{\circ}, 70^{\circ}$

DIMENSŐES

Comprimento: $69 \mathrm{~mm}$

Largura: $58 \mathrm{~mm}$

Espessura: $20 \mathrm{~mm}$

MATÉRIA-PRIMA: Arenito Silicificado

FORMA/DESCRIÇÃO

Prisma sub-circular, sem córtex, com dois bordos ativos, um ao longo de cada lateral, por toda sua extensão. Um dos bordos possui retoque direto em coche, enquanto o outro possui retoques diretos, curtos em forma de escama de maneira a formar um perfil denticulado Os ângulos dos bordos ativos sugerem 1 função.

MUSEU DE ARQUEOLOGIA E ETNOLOGIA DA UNIVERSIDADE DE SÃO PAULO SÍTIOS LÍTICOS NO INTERIOR PAULISTA: UM ENFOQUE REGIONAL 

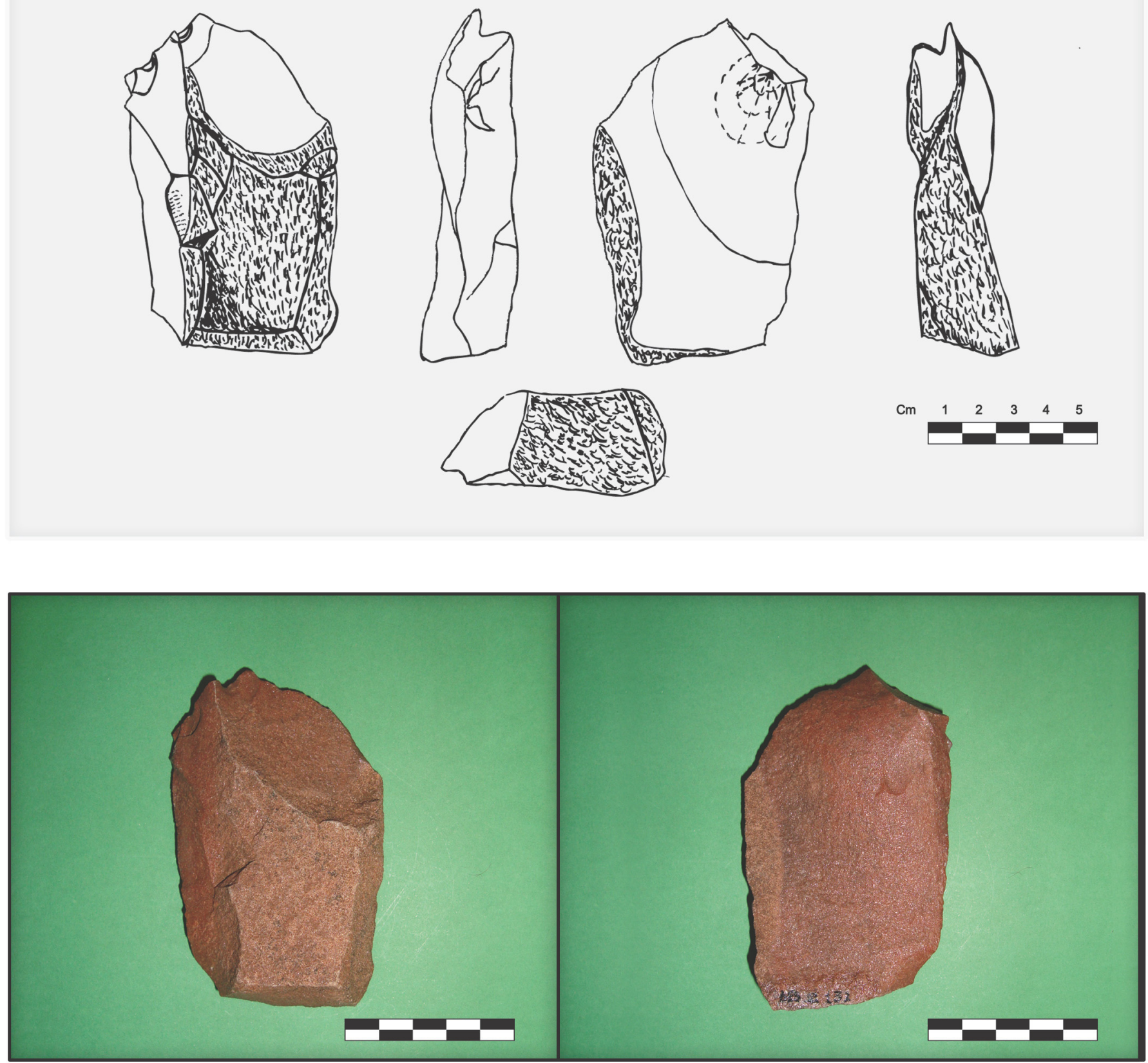

PEÇA BES III 132

Instrumento informal sobre lasca unipolar

BORDOS ATIVOS: $2-40^{\circ}, 60^{\circ}$

ÂNGULO DO TALÃO: $120^{\circ}$

DIMENSÕES

Comprimento: $94 \mathrm{~mm}$

Largura: $56 \mathrm{~mm}$

Espessura: $22 \mathrm{~mm}$

MATÉRIA-PRIMA: Arenito Silicificado

FORMA/DESCRIÇÃO

Prisma retangular, com $50 \%$ de cortex, com um gume frontal, ocupando toda sua extensão distal, e outro gume que se estende por toda uma de suas laterais. Os ângulos dos bordos ativos sugerem 1 função.

MUSEU DE ARQUEOLOGIA E ETNOLOGIA DA UNIVERSIDADE DE SÃO PAULO SÍTIOS LÍTICOS NO INTERIOR PAULISTA: UM ENFOQUE REGIONAL
Sítio Boa Esperança III

Boa Esperança do Sul, SP 

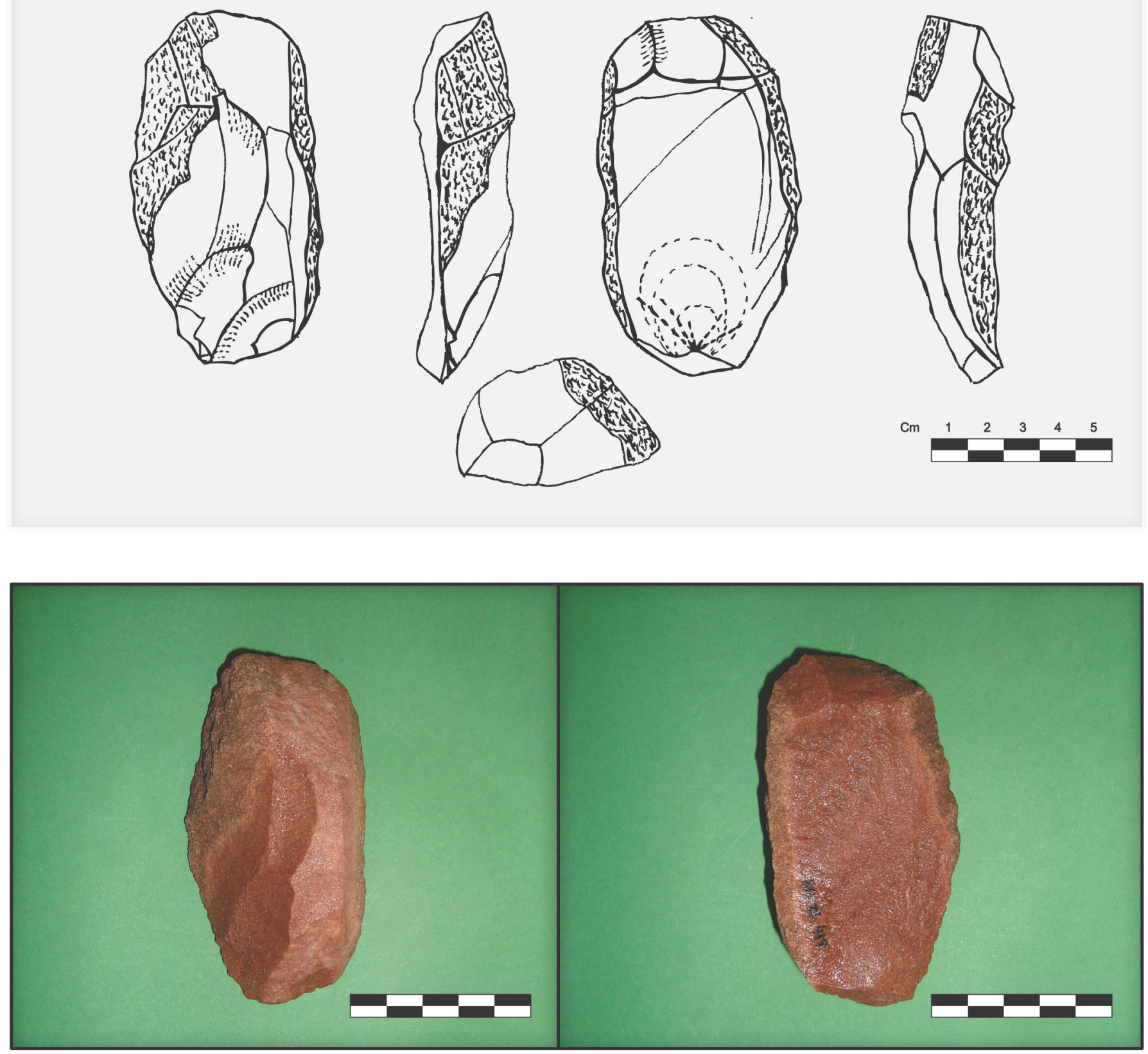

\section{PEÇA BES III 419}

Instrumento informal sobre lasca unipolar

BORDOS ATIVOS: $1-60^{\circ}$

ÂNGULO DO TALÃO: $110^{\circ}$

DIMENSÕES

Comprimento: $84 \mathrm{~mm}$

Largura: $45 \mathrm{~mm}$

Espessura: $20 \mathrm{~mm}$

MATÉRIA-PRIMA: Arenito Silicificado

FORMA/DESCRIÇÃO

Plano-Convexo, com cortex nas face interna e externa, com retiradas em uma de suas laterais, em sentido de criar um gume. Também existem duas retiradas na face interna em sua porção distal. A forma do utensilio e o ângulo do bordo ativo sugere 1 função.

MUSEU DE ARQUEOLOGIA E ETNOLOGIA DA UNIVERSIDADE DE SÃO PAULO SÍTIOS LÍTICOS NO INTERIOR PAULISTA: UM ENFOQUE REGIONAL
Sítio Boa Esperança III

Boa Esperança do Sul, SP 

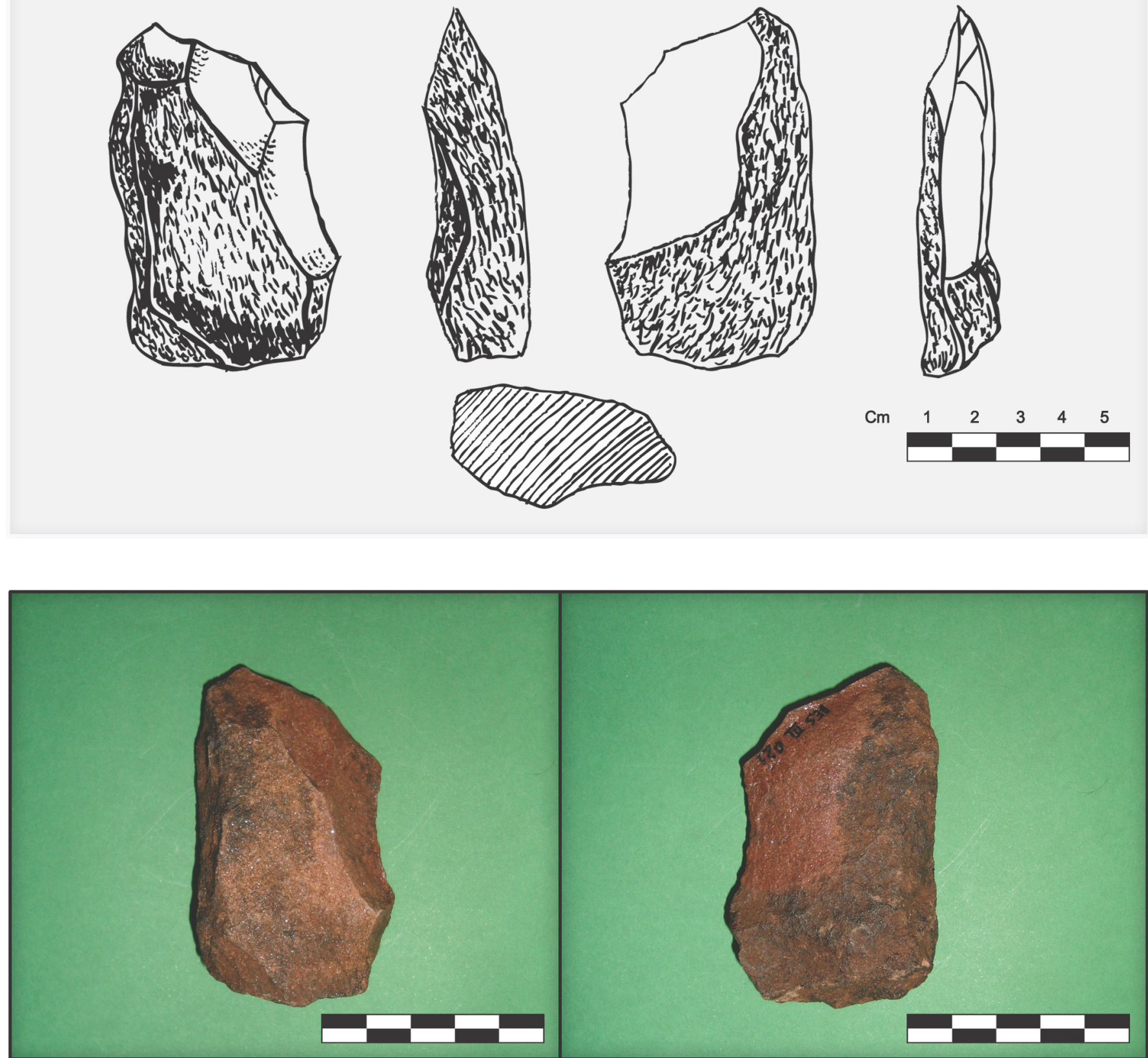

PEÇA BES III 021

Instrumento informal sobre bloco

BORDOS ATIVOS: 1 - $45^{\circ}$

DIMENSÓES

Comprimento: $70 \mathrm{~mm}$

Largura: $38 \mathrm{~mm}$

Espessura: $17 \mathrm{~mm}$

MATÉRIA-PRIMA: Arenito Silicificado

FORMA/DESCRIÇÃO

Prisma retangular, com $75 \%$ de cortex, com 1 gume formado por retoques diretos que se estende da parte frontal à quase totalidade de uma das laterais da peça. Há marcas de ação térmica. Gume formado por três retiradas, cujo ângulo sugere 1 função.

MUSEU DE ARQUEOLOGIA E ETNOLOGIA DA UNIVERSIDADE DE SÃO PAULO SIITIOS LÍTICOS NO INTERIOR PAULISTA: UM ENFOQUE REGIONAL
Sítio Boa Esperança III Boa Esperança do Sul, SP 

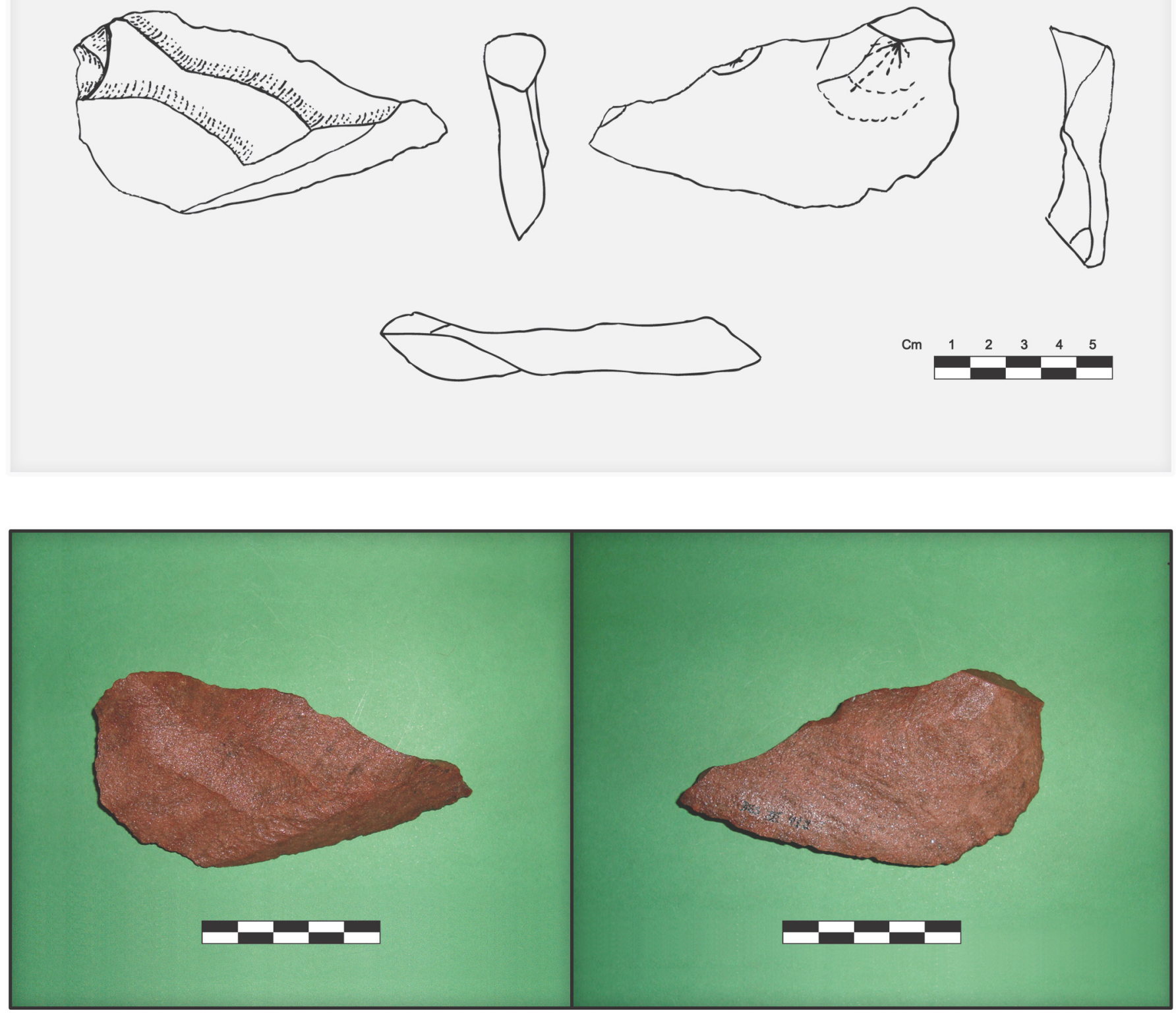

PEÇA BES III 412

Instrumento informal sobre lasca unipolar

BORDOS ATIVOS: $3-40^{\circ}, 25^{\circ}, 40^{\circ}$

ÂNGULO DO TALÃO: $110^{\circ}$

DIMENSÕES

Comprimento: $50 \mathrm{~mm}$

Largura: $95 \mathrm{~mm}$

Espessura: $10 \mathrm{~mm}$

MATÉRIA-PRIMA: Arenito Silicificado

FORMA/DESCRIÇÃO

Prisma triangular, acompanhando a própria forma da lasca unipolar, onde os gumes se distribuem ao longo de seu corpo, sendo dois em suas laterais e um próximo ao seu vértice. Os ângulos dos bordos ativos sugerem 1 função.

MUSEU DE ARQUEOLOGIA E ETNOLOGIA DA UNIVERSIDADE DE SÃO PAULO SÍTIOS LÍTICOS NO INTERIOR PAULISTA: UM ENFOQUE REGIONAL 


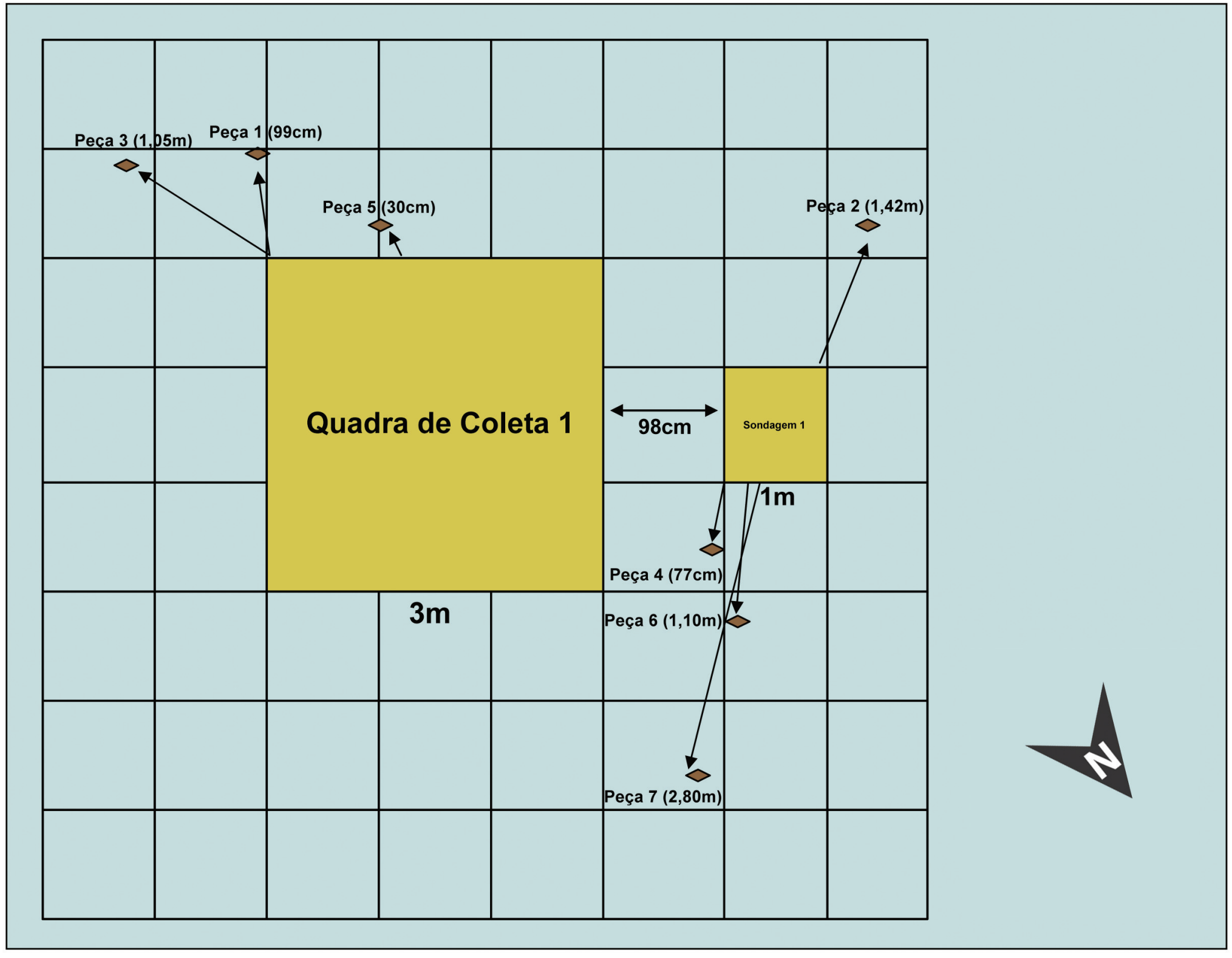

\section{SÍTIO BES III}
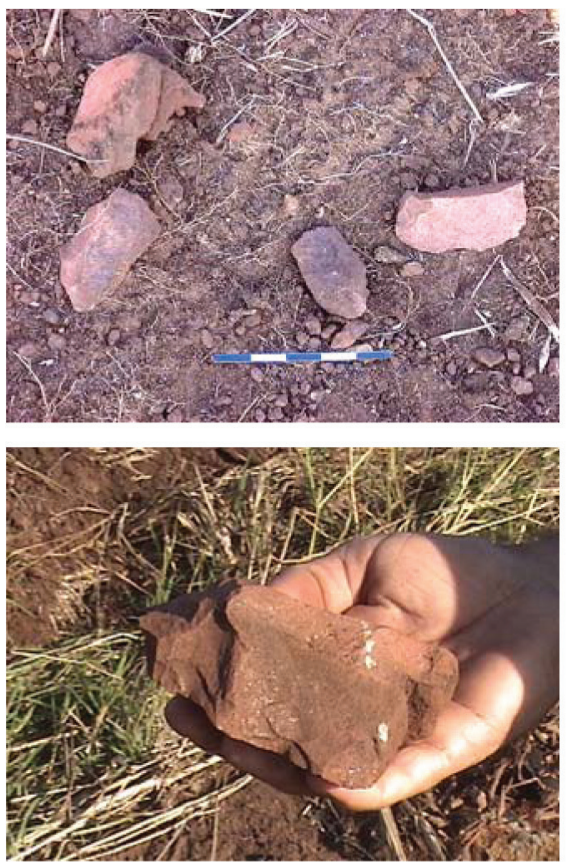

Croqui dos trabalhos desenvolvidos no sítio envolvendo delimitação, implantação de malha de referência, sondagem, tradagens e coleta sistemática em área de $9 \mathrm{~m}^{2}$.

MUSEU DE ARQUEOLOGIA E ETNOLOGIA DA UNIVERSIDADE DE SÃO PAULO

SÍTIOS LITICOS NO INTERIOR PAULISTA: UM ENFOQUE REGIONAL
ORIENTANDO

FÁBIO GROSSI DOS SANTOS
Plano de Intervenções Arqueológicas Sítio BES III Etapa 1

Fonte: Zanettini. 2003 


\section{IV.4.1) Estratigrafia}

No sítio BES III foram realizadas duas unidades de escavação, uma na primeira estapa de campo e outra na segunda. As duas atingiram a profundidade de $40 \mathrm{~cm}$, até o embasamento rochoso, e foi observado para ambas um único estrato. O solo se manteve homogêneo, do tipo Latossolo Vermelho-Amarelo álico.

\section{IV.4.2) Cronologia}

Para esse sítio, também foi feita a coleta de sedimentos para datação por Luminescência oticamente estimulada (LOE). A amostra foi retirada da profundidade de 20 centímetros, último nível onde foi detectado material-arqueológico na unidade de escavação. O resultado obtido foi de 4.500 +- 600 anos antes do presente.

\section{IV.4.3) Análise de dados}

Podemos, a partir do exposto, destacar para o sítio BES III, sua localização, em alto de colina, contiguo a um afloramento de arenito silicificado, que caracterizou a totalidade da matéria-prima. Sua indústria lítica, assim como aos demais sítios, expediente, mostra pouco dispêndio de tempo na confecção dos instrumentos, isso, provavelmente devido à grande oferta de matéria-prima, que também influiu no tamanho das peças. As atividades nele realizadas, que através dos ângulos dos instrumentos (entre 60 e 90²), mostram ser atividades específicas, como a raspagem, havendo somente um instrumento pontiagudo. O que chama atenção para o caso do sítio BES III é a ausência de percutores. Uma das razões para o retorno a esse sítio na segunda etapa de intervenção arqueológica foi justamente confirmar a existência ou não desse artefato. Porém, nada foi encontrado. Sendo assim, fica a incógnita. No local, por ser um alto de colina, não se encontram seixos, normalmente usados para essa função. Pode-se pensar então, que outra categoria de instrumentos teria sido usada para esse fim, como no caso do Sítio Dois Córregos, onde foram encontradas evidencias desse uso para esse fim em núcleos e lascas unipolares. Contudo, não foram encontrados nas peças analisadas vestígios que indicassem isso. Mesmo assim, essa hipótese se mostra a mais coerente, mesmo que nada nesse sentido tendo sido encontrado, 
pois por algum motivo esses instrumentos podem não estão mais lá, - podem ter sido carreados pelo intemperismo ou mesmo a ação do homem - ou seja, por ser uma peça rara, devido as condições impostas pelo local, foram levados pelos artesãos.

A cronologia apresentada, feita pela análise de LOE, mostra um grupo que habitava uma região já intensamente povoada por grupos caçadores-coletores, assim como nos mostram as datas para essa classe de sítios no interior paulista. A idade obtida para este sítio foi de 4.500 +- 600 anos antes do presente. Sua indústria lítica é expedita, mostrando a formatação de blocos de arenito silicificado sem padronização e poucos retoques, no sentido de atender uma necessidade imediata. Os ângulos dos bordos ativos, em sua grande maioria, entre 50 e $60^{\circ}$, seguidos dos ângulos entre 70 e $80^{\circ}$. Isso nos sugere a funcionalidade para raspar, destacando, portanto, um acampamento sazonal de atividades específicas, aproveitando sua localização estratégica, para usar o lugar como uma oficina de lascamento. Tal indústria tem semelhanças com as da região do Paranapanema, o que nos faz pensar que, devido a mobilidade conhecida entre os caçadores-coletores, não seria de se surpreender o contato entre essas regiões. Afinal, como afirma Astolfo Araújo (2001: 326), o arenito silicificado é encontrado na Depressão Periférica - Formação Serra Geral -, ou seja, região geológica onde se encontram os sítios BES, o sítio Dois Córregos e os sítios do Vale do Paranapanema.

\section{CAPITULO 5 - SÍTIOS LÍTICOS NO CENTRO-OESTE PAULISTA}

Neste capítulo, usamos os dados obtidos com as análises dos sítios BES e Dois Córregos para, juntamente com dados da bibliográfica especializada, desenvolver hipóteses sobre a ocupação caçadora-coletora na região central do Estado de São Paulo. Reforçamos que sabemos da insuficiência da amostra do registro arqueológico (somente três sítios), e, por isso mesmo, as interpretações serão mais alicerçadas nas fontes bibliográficas. Os dados sobre os demais vestígios - ocorrências e sítios líticos - identificados na região, que também são usados para a elaboração das hipóteses, são retirados dos relatórios finais quando trabalhos derivados de licenciamento ambiental - e textos acadêmicos desenvolvidos. São inseridos no contexto dessa análise mais vinte sítios líticos e quarenta e cinco ocorrências. Nem todo o material arqueológico e os sítios são conhecidos 
pessoalmente pelo autor, entretanto, grande parte o é. O resto é conhecido pela leitura dos trabalhos realizados.

Os três sítios analisados apontam para a diversidade de ocupação de espaço dos grupos caçadores-coletores: alto de colinas, médias vertentes de colinas e próximo a leitos de rios. Como mostramos no capítulo específico das análises dos sítios, fica claro um dos motivos da escolha do assentamento: a proximidade com a fonte de matéria-prima para a confecção de suas ferramentas, nesse caso, a rocha. Embora uma ocupação topograficamente diversificada também possa estar relacionada a problemas sazonais, tendo os pontos mais altos sendo ocupados durante a época de chuvas, fora do alcance de inundações (Caldarelli, 1983: 287).

O Sítio Dois Córregos esta implantado em uma média vertente de colina, o que lhe promove uma boa visão da área circundante. Há em sua área veios, onde afloram o basalto e arenito silificado, e de onde os habitantes pré-históricos tiraram proveito.

Os sítios BES II e III estão implantados respectivamente, no terraço aluvial do rio Jacaré-Guaçu e em alto de colina. Contudo, os dois estão localizados no que se chamam Terras Baixas do Jacaré-Guaçu. No Sítio BES II, praticamente do lado do rio, os homens pré-históricos se valeram das cascalheiras para obter a fonte material de confecção de suas ferramentas.

A dificuldade que muitas vezes se encontra na distinção de terraços aluviais é rapidamente superada com a análise de perfil de solos em trincheiras abertas adjacentes as atuais planícies de inundação: dentre as características obtidas do perfil se destaca a intensa gleissificação ao qual o conjunto dos horizontes do solo foi submetido, propagando-se ao menos até $60 \mathrm{~cm}$ de profundidade. Cascalhos encontrados a partir de $60 \mathrm{~cm}$ destacam-se pela elevada granulometria - os maiores chegam a exceder $20 \mathrm{~cm}$ de raio. Dentre as litologias encontradas antes de $60 \mathrm{~cm}$ ocorre um misto de clastos provavelmente transportados das Rampas ou mesmo Terras Altas próximas e de outros cuja origem está relacionada a própria pedogênese e gleissificação - notadamente os conglomerados formados por seixos de arenitos (Michelutti, 2010).

No sítio BES III, por sua vez, aproveitou-se do afloramento rochoso de arenito silicificado e basalto. Se considerarmos a data de 4.500 +-600 A.P. para a ocupação do sítio, temos um grupo habitando uma região que passava pelas tranformações do ótimo 
climático (Ab’Saber, 1977). E pode ter sido nessa época também que se formou o afloramento rochoso do qual se valeram os lascadores que ali se assentaram. Tal afloramento não é parte de um veio de derramamento basáltico que cobriu o arenito, dandolhe silica, e tampouco é parte de um morro residual ou algo assim. Parece tratar-se de grandes clastos que foram carreados (e não rolados, pois não são seixos) por forças originadas de grandes mudanças climáticas - por isso a idade desse afloramento pode estar de acordo com a data do ótimo climático - de zonas mais altas, as chamadas terras altas de Araraquara ou Rampas e Patamares Transicionais.. Foram carreadas até as terras baixas do Jacaré-Guaçu e aí se acomodaram, tornando-se estáveis e acumulando sedimento. Sobre esse sedimento foi depositado o produto de lascamento dos homens pré-históricos que por ali passaram.

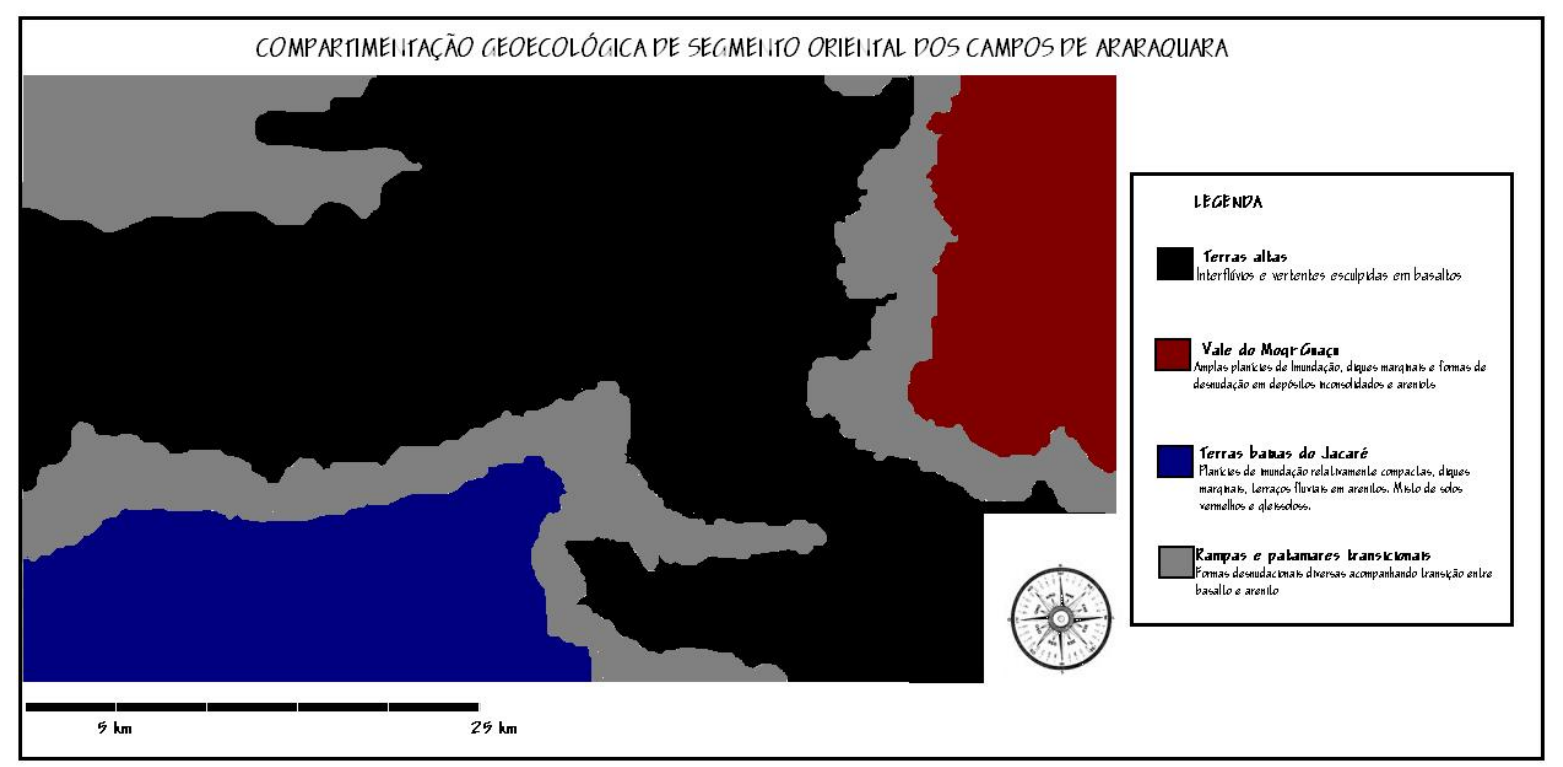

Imagem 10: Distribuição espacial das unidades geoecológicas ao longo na área de estudo.

(Michelutti, 2010) 


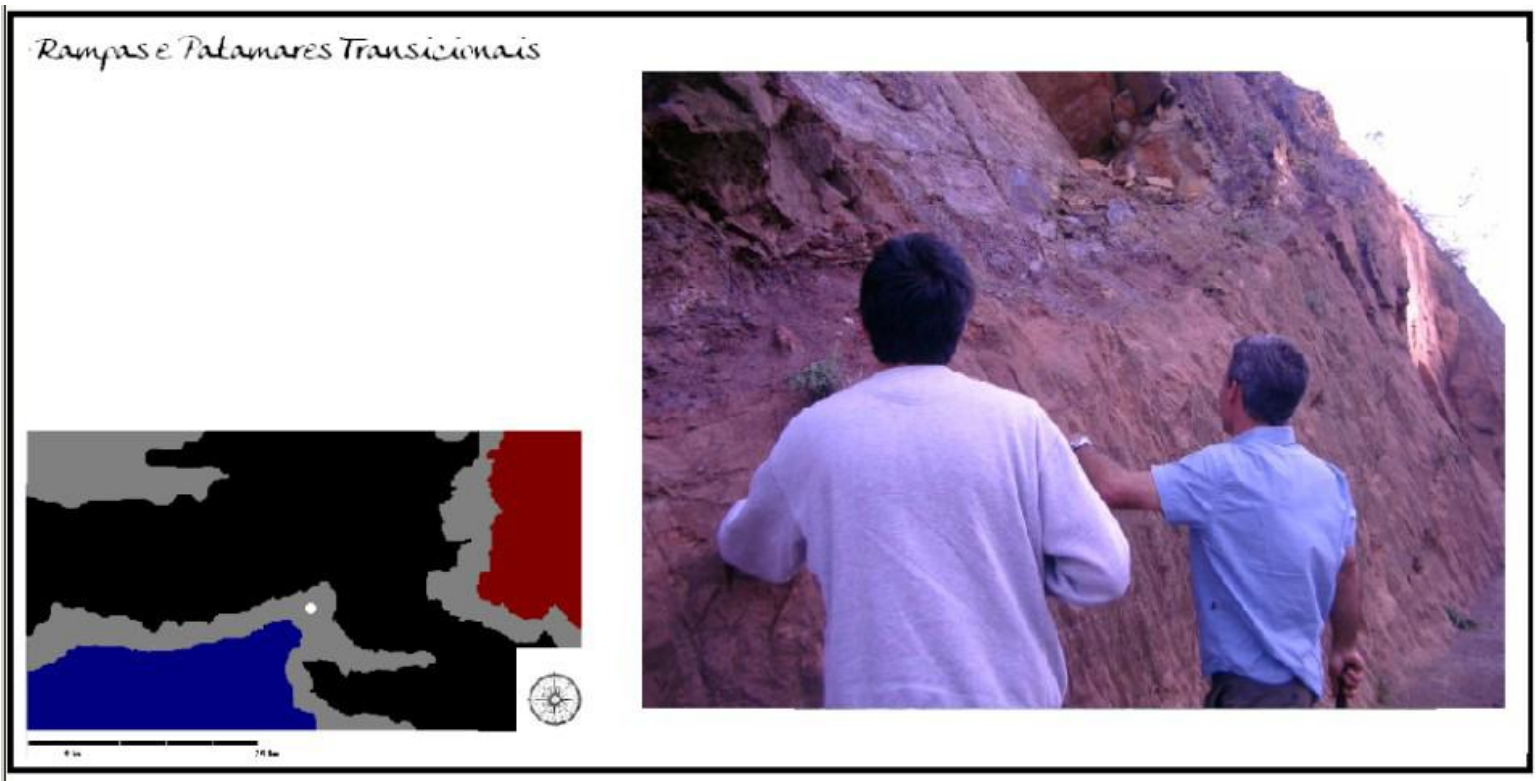

Imagem 11: Contato dos basaltos e arenitos respectivos da formação litoestratigráfica Serra Geral e Botucatu na área de Rampas e Patamares Transicionais. Os clastos do sítio BES III, poderiam ter se deslocado dessa região (Michelutti, 2010).

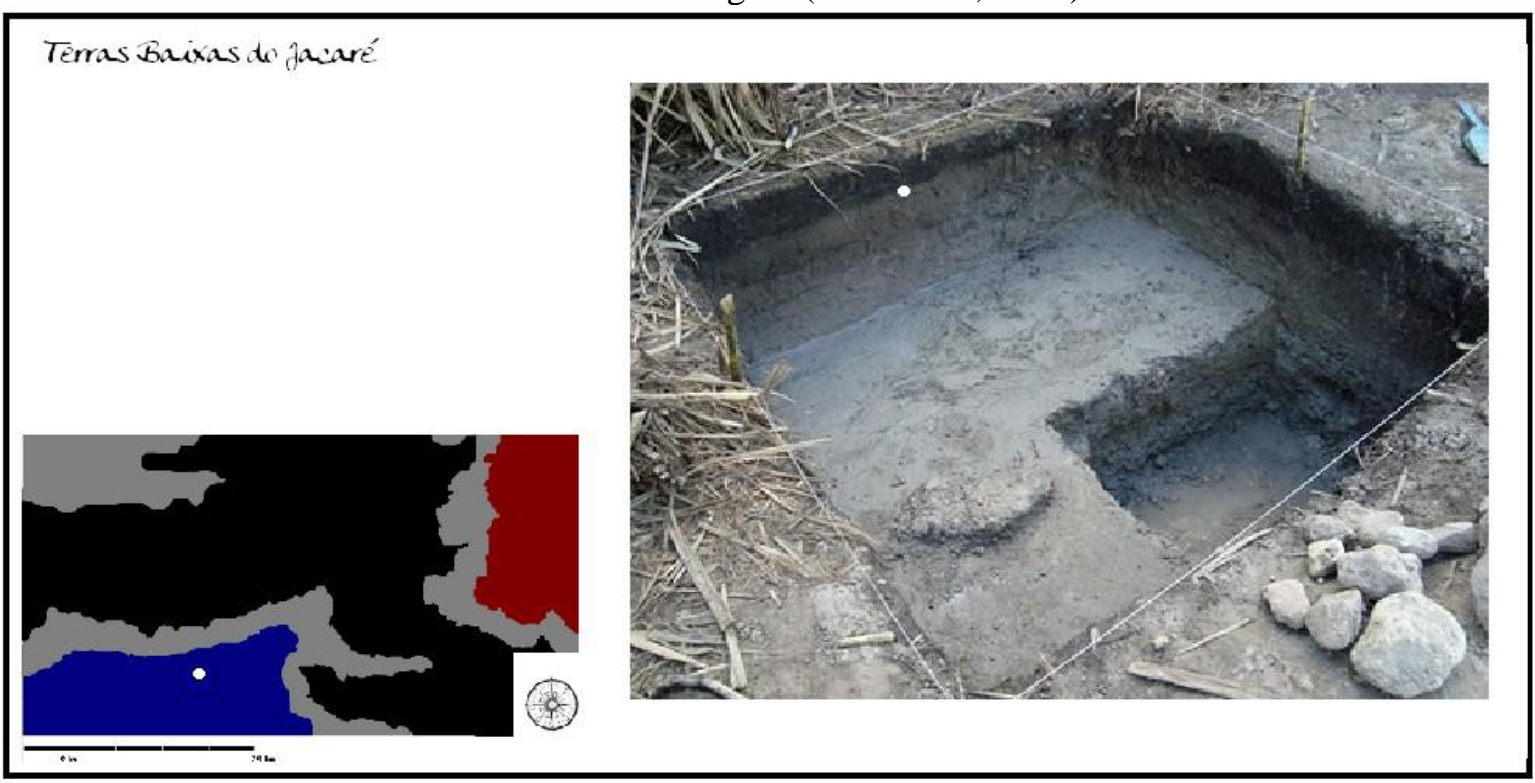

Imagem 12: Localização do sítio BES II no limite entre as rampas e terras baixas do Jacaré; destaque unidade de escavação 01 - 2a etapa de campo (Michelutti, 2010). 


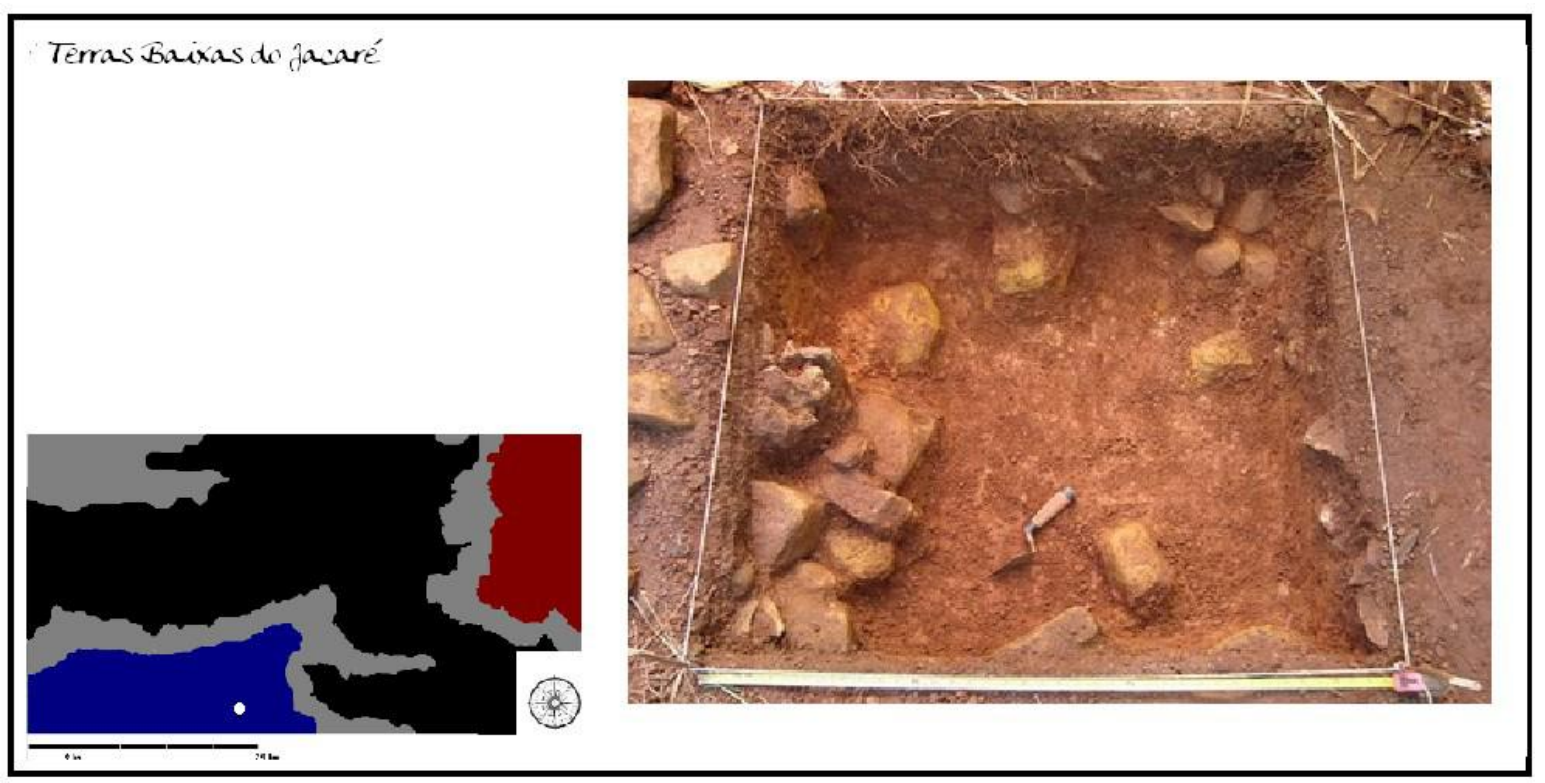

Imagem 13: Localização sítio BES III - clastos de basaltos encontrados em discreta saliência localizada da altimetria média das Terras Baixas do Rio Jacaré; destaque para unidade de escavação - $2^{\text {a }}$ etapa de campo (Michelutti, 2010).

Percebemos ainda, a diversidade de assentamentos, que indicam sistemas de sítios, onde cada um teria uma função, como habitação, oficina de lascamento, acampamento de caça, etc. Poderíamos ilustrar essa situação através de estudo etnoarqueológico de Gould (1980) citado por Solange Caldarelli, em trabalho com aborígenes australianos na localidade de Tikatika. Ele “descreve uma área de habitação composta por cinco áreas residenciais, três delas maiores, ocupadas por três famílias nucleares e duas delas menores, ocupadas respectivamente por um solteiro e uma viúva. (...) Incursões para procura de alimentos, durante o dia, levavam tanto homens quanto mulheres a pararem em acampamentos onde algumas atividades eram desenvolvidas, tais como cocção de alimentos e preparo e reavivagem de artefatos. (...) O que diferenciava os acampamentos das habitações era muito mais a quantidade que a diversidade de vestígios remanescentes” (1983: 290). Nos três sítios estudados vemos essa situação. E se ampliarmos o escopo e fizermos uso de mais sítios líticos como exemplo, esse padrão se torna ainda mais claro. Aliás, para se afirmar isso, na verdade, de fato torna-se necessário fazer uso de mais sítios, pois somente os BES e o Dois Córregos não são suficientes. Seriam talvez, se fossem contemporâneos. Mas pelo menos dois deles já sabemos que não são. Assim, buscando o enfoque regional - que é a proposta deste trabalho - o panorama esboçado pela dispersão de sítios líticos na região central do Estado de São Paulo parece mostrar o mesmo padrão 
verificado na região de Ribeira do Iguape, destacado no item 3 do primeiro capítulo deste trabalho. Temos um padrão nucleado de assentamento, com sítios mais densos, de atividades diversificadas, associados a outros menores, de atividades restritas (De Blasis, 1988). Além do sítio BES II e III, temos o BES I, também em alto de colina e o menos denso dos três, com um total de apenas 36 peças coletadas, todas de arenito silicificado. Próximos a eles, na região de Araraquara temos mais dois - o Córrego dos Andes e Ribeirão das Cruzes - envolvidos em ocorrências líticas. Em Itapuí foi identificado um sítio lítico (T- 51) com algumas ocorrências em suas proximidades. Não muito distante dele, no município de Jaú, temos o sítio $\mathrm{T}$ - 92, com grandes dimensões e instrumentos formais; e também o sítio Monte Alegre, pouco denso, com menos de 20 peças. Próximo a esse município temos Bocaína, também com dois sítios líticos identificados, ambos de pequenas proporções (Bocaína I e II). Em Botucatu temos o mesmo, com 4 sítios líticos cadastrados Sítios BTC 22.530.573, Fazenda Edgardia I e II e Fazenda Lajeado I. Na cidade de Boracéia há um sítio lítico com instrumentos formais (Boracéia II) e no município de Gavião Peixoto, temos um sítio denso, com mais de 2 mil peças coletadas, outro menor a 120 metros de distância - Sítios Gavião I ${ }^{22}$ e II -, além do Sítio Remanso. Em Santa Lúcia, o sítio Rainha dos Montes ocupa uma grande área e possui diversas ocorrências em seu redor. O Sítio Dois Córregos, no município que lhe dá nome, também se caracteriza como denso, e possui ocorrências em suas imediações. Ainda em Dois Córregos, hoje em margem represada do Rio Tietê, para a represa de Barra Bonita, na região dos Três Rios, temos o sítio homônimo, denso, com 531 instrumentos e uma indústria lítica formal ${ }^{23}$. Sabemos ainda por diversas fontes orais e por contato direto com moradores da região que no mesmo local, outros sítios líticos com a mesma proporção foram encontrados (inclusive foi feito registro fotográfico). Não podemos deixar de citar também o sítio Pederneiras I, o sítio Brotas e o sítio Bauru, sendo este último, o único, juntamente com o BES II, a ter material em profundidade - nele foi encontrado material a dois metros de profundidade. O mapa a seguir ilustra esse contexto.

\footnotetext{
${ }^{22}$ Este sítio não consta no mapa da relação de sítios, ocorrências líticas e afloramentos areníticos na região central do Estado de São Paulo, por conta da proximidade com o sítio Gavião II.

${ }^{23}$ Quando nos referimos aqui a instrumentos formais queremos dizer artefatos plano-convexos, incluindo para o sítio lítico Três-Rios, pontas de projétil - foram identificadas 79 ao todo.
} 
Notamos então, dentro desse escopo, a referência ao estudo de Paulo de Blasis (1988), ou seja, complexos menores, com sítios mais próximos uns dos outros, dentro de complexos maiores, com sítios distantes entre si, nesse caso, uma média de 50 a 80 quilômetros. Da mesma forma, há a relação entre sítios de atividades específicas com sítios de atividades diversificadas, sitos mais e menos densos. Sempre estão margeados por ocorrências, o que indica a circulação constante dessas populações dentro de seu território. Sobre esta situação podemos traçar um paralelo com os Nukak, grupo da família lingüística Makú-Puinave, ou simplesmente Maku. Estão distribuídos geograficamente entre o Brasil e a Colômbia, principalmente a leste do Rio Negro, entre os rios Guaviare e Caquetá. Os Nukak ocupam um território de $10.000 \mathrm{Km}^{2}$, com uma população estimada entre 400 e 500 pessoas, organizadas em bandos isogâmicos autônomos, divididos em várias famílias (entre duas e cinco). A composição de cada família se dá, em média, entre 12 e 44 indivíduos, caracterizando-os como os maiores grupos que co-residem entre 20 e 30 indivíduos. Cada bando é afiliado a um grupo maior denominado “Munu”. Com essa organização social, é possível compartilhar territórios, obter casamentos, realizar visitas sociais e ritualísticas. A falta de organização social, a alta solidariedade e a alta mobilidade, por conseguinte, são características dos Nukak (Politis, 2001 apud Oliveira, 2007).

Sobre a dispersão desses sítios na região, como vemos no mapa da dispersão dos vestígios arqueológicos no centro-oeste paulista, é preciso mencionar que os espaços em branco não significam ausência de sítios e sim, ausência de pesquisas. A área onde temos maior concentração de vestígios foi justamente a mais pesquisada. Dessa forma, podemos deduzir que se as outras áreas fossem prospectadas da mesma maneira, o número de vestígios cresceria consideravelmente e nosso mapa se tornaria mais “salpicado” de pontos.

Os sítios BES estão próximos, a uma distância de mais ou menos 5 quilômetros. Próximo a eles ainda temos o sítio BES I, sítio pouco denso. Mais distante está o Sítio Dois Córregos, a 47 quilômetros. Esse padrão de assentamento verificado também está de acordo com o que conhecemos sobre os grupos caçadores-coletores, pois no que se trata de mobilidade, a literatura nos diz que eles poderiam se deslocar uma média de até 45 a 50 quilômetros por dia. Considerando esse alto grau de mobilidade, podemos visualizar que alguns poucos grupos podem ter ocupado um território muito grande. E isso é apontado pelo registro arqueológico, onde temos, para a região do centro-oeste paulista uma área 
densamente ocupada. Os vestígios líticos deixados por essas populações estão dispersos por largo território, evidenciando esse fato.

Contudo, é preciso lembrar que Sítio lítico não é sinônimo de caçador-coletor. Entretanto, são poucos os sítios aqui destacados que parecem oferecer dúvidas quanto a essa associação. Um número reduzido deles poderia não ser de caçadores-coletores, pois estão próximos a sítios cerâmicos, e dessa maneira, poderiam fazer parte desse sistema de sítios. Assim, quase todos apontam para populações “acerâmicas”.

As indústrias líticas de cada sítio mostram um trabalho expediente, ou seja, um lascamento simples, sem grande dispêndio de tempo na confecção das ferramentas. A grande oferta de matéria-prima propiciou a obtenção de lascas grandes que sofriam retoques apenas para produzir um gume e atender uma necessidade imediata - descarnar um animal, raspar madeira, etc - e logo depois o instrumento era abandonado. Quando surgia novamente a necessidade do uso de alguma ferramenta, o lascador simplesmente produzia uma nova em pouco tempo. É constante nos sítios analisados o predomínio das lascas unipolares, com número expressivo, seguido pelos detritos de lascamento, e sendo a categoria menos expressiva a de instrumentos. Tratam-se, portanto, de indústrias líticas simples, “com alguns poucos unifaces retocados a exaustão, algumas lascas retocadas e uma grande maioria de lascas utilizadas e brutas” (Araujo, 2001: 327).

O sítio BES III destaca-se por ser um assentamento de atividades restritas, onde a maior parte de seus instrumentos é composta por raspadores, ou seja, ferramentas com a funcionalidade para raspar. É um sítio de proporções pequenas, ao redor do afloramento rochoso de arenito e basalto, em uma média vertente, de onde seus ocupantes se valeram exclusivamente do arenito silicificado disponível para usar o lugar como um acampamento sazonal e desenvolver suas atividades de lascamento.

O Sítio Dois Córregos destaca-se por sua área mais ampla e maior número de material arqueológico, estando em uma média vertente. Isso evidencia um acampamento sazonal, porém, diferente do BES III, pois seu uso foi mais intenso. Um dos motivos da escolha do local do assentamento se deu pela presença de afloramento de arenito e basalto. Também ficam evidentes, dentro do sítio, as áreas de atividades distintas, corroborando para a divisão espacial do ambiente. Através da análise dos instrumentos desse sítio, temos 
uma incidência maior para as atividades de raspagem, e uma menor proporção para o corte. Temos assim, um sítio acampamento para atividades restritas.

O Sítio BES II é o mais diversificado. Foi assentado no terraço aluvial do Rio Jacaré-Guaçu. Um dos motivos da escolha do local de assentamento se deu pela presença, além do rio, da cascalheira, que fornecia ao homem pré-histórico, assim como nos outros dois sítios, uma rica fonte de matéria-prima para o lascamento. Possui maior número de material arqueológico, sua área é mais ampla, tanto horizontal, quando verticalmente. Aliás, esse fato mostra uma ocupação prolongada no tempo. Os níveis mais profundos possuem uma quantidade menor de material, parecendo estarem associados a grupos menores de caçadores-coletores que se aproveitaram dos mesmos seixos, nódulos e blocos de arenito silicificado, sílex, quartzo e conglomerado, usados pelas ocupações dos níveis superiores. Temos assim, até os cinqüenta centímetros de profundidade, uma maior população ou então o uso mais intenso do espaço. Qualquer das alternativas denuncia grupos de caçadores com um modo de vida não tanto nômade, ou mais populosos. As atividades realizadas nesse sítio, caracterizado como habitação, são mais diversificadas que as dos sitos BES III e Dois Córregos. Seus instrumentos sugerem atividades para raspagem, corte e perfuração. Seriam necessárias mais atividades de campo para esse sítio, de modo a entender melhor o assentamento; de preferência uma intervenção por superfícies amplas, para detectar áreas de atividades específicas, pisos de ocupação e materiais orgânicos (fibras vegetais, restos alimentares, carvão, estruturas de combustão, etc).

Comparando esses dados com os demais sítios líticos identificados na região, notamos para todo o território a predominância das indústrias líticas simples, o que não quer dizer que os grupos humanos que as produziram não possuíam complexidade em sua organização social, e sim, que poderiam não dar tanta importância para o lascamento, o tendo como atividades talvez, secundárias. Os Xetá, no Brasil, que foram estudados por Tom Miller Jr. (1979, apud Araújo 1995) utilizam-se da pedra de modo pouco sofisticado, com o emprego de uma tecnologia expediente, mas que, atendia de maneira bastante satisfatória as necessidades cotidianas de seus fabricantes. A técnica preferida pelo lascador era o espatifamento, feito com repetidos golpes do percutor. Depois de obtidas as peças, o lascador separava as que mais se adequavam à tarefa em questão. Nesse caso, a preferência era pelo uso da madeira, e não da pedra. Assim, vemos que "a atividade de lascar pode ser 
considerada por algumas populações como banal e utilitária, não merecendo por parte do lascador o dispêndio de mais que alguns minutos na confecção de artefatos simples $e$ funcionais" (Araújo 1995: 68).

Quanto às atividades realizadas dentro dos sítios arqueológicos, evidenciadas pelos gumes dos instrumentos, destaca-se as atividades para raspagem. O maior número de instrumentos encontrados não só nos três sítios analisados, mas também em todos os outros da região centro-oeste paulista aqui citados, são os chamados pela tipologia de raspadores. Além das formas estarem de acordo com a função para raspar, os ângulos dos bordos ativos também convergem nesse sentido. Sobre isso, voltando ao caso dos últimos representantes dos Xetá do Paraná no Brasil, Tom Miller Jr., observando suas atividades de lascamento, aponta que os ângulos utilizados no trabalho da madeira estariam entre 65 e 85 graus. Em muitos casos uma única lasca pode ter vários usos, sendo usada em diferentes etapas de um mesmo trabalho (apud Araújo, 1995). Vemos essa situação em outros casos como os aborígenes dos desertos do Oeste da Austrália, onde um dos principais utensílios por eles usado, denominado 'Kandi'tjuna:

resume-se a uma lasca bruta fixada na ponta de um propulsor e serve para todos os fins: cortar carne, confeccionar e aguçar dardos ou lanças de madeira, etc. O gume é reavivado sucessivas vezes por retoques feitos tanto por percussão com percutor duro, quanto por pressão, adquirindo o aspecto inicialmente de um pequeno raspador convexo e, depois, côncavo. Quando o gume encontra-se totalmente esgotado, a lasca é virada do outro lado e o processo recomeça no bordo oposto. A peça final, esgotada e rejeitada, apresenta-se como um pequeno raspador duplo côncavo, duplo convexo ou duplo côncavo/convexo, com os bordos abruptamente retocados (...). Um outro instrumento, a tula, é retocada em forma de raspador desde o início e inserida na haste do lado do talão. (...) mas nesse caso, as transformações descritas acima ocorrem apenas no bordo distal (Caldarelli, 1983: 295).

O mesmo poderia ter ocorrido na região aqui estudada, onde as formas dos instrumentos descritas nos exemplos apresentados possuem semelhanças, bem como a média dos ângulos obtidos - especialmente os BES e Dois Córregos - que está de acordo com o descrito por Tom Miller Jr.

Comparando os Sítios BES e o Dois Córregos com as demais regiões do Estado, nos remetendo ao contexto arqueológico descrito em nosso primeiro capítulo, encontramos características em comum com a região do Paranapanema. Os sítios Almeida e Camargo 
são marcados por indústrias líticas e formas de assentamento semelhantes aos da região central. O Primeiro Sítio, estudado por Águeda Vilhena Vialou em seu doutoramento de 1980, obteve, durante as escavações, uma amostra para o primeiro nível lítico de 3.455 peças, onde predomina o arenito silicificado. É uma indústria, basicamente sobre lascas unipolares, com destaque para os utensílios com funcionalidade para raspar. Sua implantação se dá ao ar livre, em colina de pequena elevação e próximo a ribeirão e a data obtida para esse ocupação foi de 3.600 A.P. (Vilhena, 1980). O segundo, estudado por José Luiz de Morais também em seu doutoramento de 1980, apresenta um sítio de características similares, com a predominância do arenito silicificado. A data obtida para a ocupação desse sítio foi de 4.560 A.P. (Morais, 1980). Incluímos nesse contexto também, o sítio Brito, também analisado por Águeda V. Vialou (1983), com 7.000 anos.

Os sítios líticos das demais regiões de São Paulo, os mais conhecidos, possuem características distintas. Os complexos onde se encontram Alice Bôer e o Abrigo Sarandi são marcados por indústrias formais, caracterizadas pela presença das pontas de projétil e a predominância do Sílex como matéria-prima. O sítio Água Vermelha 3, em Ouroeste, tem um grande diferencial, pois se conservaram ossadas humanas das populações que ocuparam o extremo norte do Estado de São Paulo há 9 mil anos atrás.

Contudo, as características descritas não são para todos os sítios da região. Alguns deles merecem destaque. Como discriminado acima, alguns sítios possuem indústrias líticas formais. São eles: Boracéia II, T- 92 e o sítio lítico Três Rios. Esses se caracterizam pela presença marcante do plano-convexo, e no caso do Três Rios, também a ponta de projétil. Extrapolando um pouco a área de pesquisa, no município de Rincão, temos o sítio lítico homônimo do município, que foi alvo de pesquisa de mestrado de Danilo Galhardo (2010). Este sítio também possui uma indústria lítica formal, marcada pela presença, assim como o sítio Três Rios, de artefatos plano-convexos e pontas de projétil. Para esse diferencial, seriam necessários mais estudos, para que se possa entender sua inserção nesse contexto regional. Assim sendo, percebemos que se torna difícil classificar essas indústrias com o que se conhece sobre tipologia de arqueologia brasileira.

\section{V.1.) CAÇADORES-COLETORES NO INTERIOR PAULISTA}


A partir do exposto, a intensidade dos grupos caçadores-coletores na área de pesquisa e a sua diversidade de ocupação dos espaços ficam marcadas como características da região. Mas algumas perguntas surgem em conseqüência disso, tais como: Quando esses grupos se instalaram no local, de onde vieram e por quanto tempo ficaram. Se considerarmos como válidas as datas dos sítios BES III e BES II, 4.500 +- 600 AP. e 14.500 +- 3.000 A.P., respectivamente, temos uma região ocupada por longo período de tempo, mas trata-se de uma informação imprecisa.

Ao analisar os sítios caçadores-coletores datados do Estado de São Paulo, notaremos uma ocupação ainda mais prolongada, havendo registros já do século XX, até 14 mil anos atrás. Considerando as datas seguras, o período regride entre 9 e 11 mil anos atrás, mas, ainda assim em período pleistocênico. Atentando-nos para a dispersão desses sítios mais antigos, percebemos que se espalham por praticamente todo o território paulista. Temos sítios de 9 mil anos no extremo norte de São Paulo e também região nordeste (sítios Água Vermelha 3 e Bela Vista 2 e 3), sítios de 8 mil anos no extremo oeste (sítio Estrela do Norte 1), sítios de 7 mil anos mais ao sul, na região do Paranapanema (sítio Brito); sítios entre 5 mil e no mínimo 11 mil anos na região Centro-leste do Estado (Abrigo Sarandi e Alice Böer), sítios de 6 mil anos no extremo sul (sítio Paraíso) e por fim, sítios entre 4.500 e no mínimo 11.500 anos no centro-oeste (sítios BES III e II). Portanto, mais pesquisas no sentido de entender a rota de chegada desses grupos devem ser realizadas, pois na conjuntura atual, essa questão ainda não pode ser respondida. 
Com o panorama que se desenha, também surgem novas questões sobre como viviam essas populações. É sabido, que em geral, caçadores-coletores são caracterizados por baixa densidade demográfica, quer dizer, poucas pessoas, valendo-se da já mencionada média de 25 indivíduos por grupo. Vivem de forma igualitária, não havendo assim, hierarquia ou qualquer distinção de classes, já que todos participam das atividades de obtenção de recursos alimentares. Porém, alguns gozam de mais prestígio, baseados em dotes pessoais, como liderança ou habilidade com a caça, por exemplo, mas não porque haja algum sistema formal de chefia. Os xamãs, ou curandeiros, são especialmente respeitados, sobretudo em épocas de crises de alimento, de guerra ou para identificação e neutralização de feitiços (Neves \& Piló, 2008). Por fim, são nômades, possuem alta mobilidade, pois estão em constante busca de alimentos, sendo que não praticam, em teoria, a agricultura.

Entretanto, as informações aqui apresentadas contribuem para as discussões sobre a diversidade que cada vez mais se consagra sobre o modo de vida caçador-coletor. Contrariando esse modelo geral, os três sítios aqui analisados de forma mais detalhada e as informações apresentadas sobre os demais sítios identificados na região de destaque, evidenciam uma situação distinta. O quadro que temos esboçado aponta para alguns assentamentos densos, indicando um maior número populacional e também um caso de sítio ocupado por longo período de tempo, o que aponta para menor grau de mobilidade. Também temos sítios menos densos, o que mostra, como já foi discutido, que podem fazer parte do sistema de assentamento desses outros sítios maiores, ou sítios-base. Completa o quadro, um grande número de ocorrências, que traz destaque para o uso intenso do espaço, onde esses grupos estariam circulando constantemente.

É um cenário diferente do que temos, por exemplo, na região do Alto Taquari, foco de pesquisa de mestrado de Astolfo Araújo, onde o padrão de assentamento mostra vários sítios poucos distantes entre si e pouco densos, onde mais de $80 \%$ de seu total possui no máximo vinte peças (1995: 64). Esse padrão sim, aponta para o modelo clássico do modo de vida caçador-coletor, pois vários sítios pouco densos indicam alta mobilidade e populações pequenas.

Se lançarmos mão da literatura existente e compararmos as informações com os dados sobre os sítios líticos da região central do Estado de São Paulo, podemos dizer que os 
grupos humanos que viveram nessa região estariam mais ou menos de acordo com o que se conhece sobre caçadores-coletores das regiões tropicais. De acordo com Lee (1968), “uma sociedade de caçadores-coletores depende, para sua subsistência, muito mais de vegetais, peixes e moluscos do que de carne propriamente dita. A caça apresenta-se com um meio de subsistência predominante apenas no Ártico. Nas regiões subtropicais e tropicais, a coleta domina amplamente sobre a caça como meio de prover a subsistência do grupo" (apud Caldarelli, 1983: 297). Temos como exceção para esse caso os Aché do Paraguai, onde a carne da caça compõe 78\% de sua dieta (Hill \& Hurtado, 1999 apud Oliveira, 2007). A caça em paisagens tropicais úmidas é muito incerta. Primeiramente pela pouca visibilidade que a floresta permite, mas principalmente pelo fato de que a maioria dos animais caçados nesses ambientes é formada por espécies solitárias ou que andam em pequenos grupos. A carne também estraga muito rapidamente, de maneira que, dois ou três dias depois de um abate, novas incursões de caça têm de ser feitas. "Entre os Maku da Colômbia, a cada quarenta incursões de caça empreendidas pelos homens, apenas treze obtém sucesso (Neves \& Pilo, 2008: 293). Destacando o modo de vida dos Nukak, Wesley Charles de Oliveira ainda comenta que entre eles, as mulheres participam de atividades logísticas em longas distâncias, mas, via de regra, elas auxiliam na subsistência do bando coletando frutos próximos a base residencial (2007: 15). “(...) tendo em vista a importância estratégica dos vegetais coletados, as mulheres (no caso do povo de Luzia) deviam gozar de grande prestígio.” (Neves \& Pilo, 2008: 293).

Pensando assim, as mulheres e crianças devem ter tido uma carga de trabalho muito grande, porque eram responsáveis pela coleta de vegetais. Dessa forma, usando o raciocínio de Walter Neves para interpretar o Povo de Luzia, poderíamos supor também que, não é impossível que, pela importância da coleta, os primeiros habitantes dessa região fossem matrilineares, diferente do que se percebe na maioria dos grupos caçadores-coletores, que são patrilineares e patrilocais. E, valendo-se da hipótese desses grupos serem matrilineares, poderia ser possível que fossem também matrilocais.

Havia entre essas populações uma alta mobilidade residencial, onde, dentro de um sistema de sítios-base associados a sítios-satélite, elas estariam periodicamente se mudando, em um sistema sazonal. Ocupando lugares distintos de acordo com as estações climáticas, e assim, quando o ciclo se repetia, da mesma forma os sítios eram reocupados ou não. 
Considerando essa alta mobilidade, visualizamos aldeias e cabanas pequenas, construídas com material facilmente deteriorável, e os acampamentos temporários, mais precários ainda. Fato distinto poderia ter ocorrido no sítio BES II, mas as pesquisas até agora empreendidas, nada revelaram contra isso. Grande exemplo de alta mobilidade verifica-se entre os Nukak, que segundo Politis, é vista como uma estratégia de adaptação à floresta. Eles modificam o ambiente natural, remanejando a flora e a fauna de um lugar para o outro. Diferente dos outros grupos etnolingüisticos ao qual fazem parte, a sua alta mobilidade faz com que organizem dois sistemas de assentamentos, o residencial e o logístico:

a) bases residenciais, com uma ocupação entre duas a cinco unidades domésticas, cada uma com sua própria fogueira;

b) acampamentos logísticos, associados às excursões exploratórias em busca de recursos específicos.

A mobilidade residencial é entendida como a mudança do sítio-residência para outro lugar, observando-se a distância a ser percorrida e a freqüência com que a mudança é feita. Entretanto, existem mudanças variáveis de acordo com a sazonalidade (...). A média anual de mudança varia entre 70 e 80 vezes ao ano. A alta mobilidade residencial dos Nukak é uma de suas principais características e uma das mais altas do mundo".

A mobilidade logística, menos freqüente, consiste em excursões de um ou vários indivíduos fora da base residencial para a execução de atividades específicas, como para obter recursos ou coletar informações” (Politis, 2001 apud Oliveira, 2007: 15).

Esse tipo de mobilidade poderia formar no registro arqueológico algo parecido com o que temos em nosso estudo: alguns sítios mais densos, com atividades mais diversificadas, e outros menos densos, com atividades restritas.

A partir desse sistema de dispersão de sítios, podemos ainda pensar na existência de vários grupos caçadores-coletores que faziam parte de uma comunidade maior, denominada “macrobando”. "A existência do macrobando é essencial para que as trocas conjugais não envolvam indivíduos muito aparentados, evitando-se assim, problemas genéticos derivados da endogamia. Além disso, o macrobando permite a formação de laços formais de apoio e reciprocidade que podem ser essenciais quando um ou outro grupo está passando por períodos de escassez. Permite também fazer alianças para a guerra, diga-se de passagem 
um comportamento endêmico entre sociedades de bandos e tribais” (Neves \& Piló, 2008: 292).

A abundante oferta de matéria-prima caracterizou, na maior parte da região, sítios com indústrias líticas mais expedientes, não impedindo, entretanto, a existência de sítios com indústrias mais refinadas. Essa variabilidade, só poderá ser melhor compreendida com a realização de mais estudos.

Variada foi a forma de ocupação do espaço. Temos sítios em altas, médias e baixar vertentes; próximos a grandes rios, de nascentes de pequenos cursos d’água e em topos de colina, até mesmo distantes de recursos hídricos.

Considerando os sítios pleistocênicos e de transição, onde o ambiente era distinto ou não tanto -, as condições em que viviam os “paleoíndios” talvez não fossem tão diferentes das holocênicas. Mesmo com a maior diferença da época, que seria a convivência com a Megafauna, isso não alteraria de forma drástica o modo de vida dos habitantes do interior paulista. Pelo que sabemos, a megafauna devia ser temida e, por isso mesmo evitada. Assim como destaca Neves \& Piló:

Jamais caçaram as grandes 'bestas' com as quais conviveram por cerca de dois mil anos. Certamente um dos pesadelos mais populares (...) era o de ser atacado por um tigre-dentes-de-sabre. Por temor a esses ataques, podem ter criado essa relação de evitação com a megafauna, tendo concentrado seus esforços na caça de animais pequenos e médios, os mesmo que continuam a existir hoje (2008: 305).

É grande a riqueza de informações e o que temos até então sobre os grupos caçadore-coletores que habitaram o centro-oeste paulista são, todavia, dados iniciais, apontando mais perguntas que respostas. São questões que se levantam, nos provocam e instigam. Dessa forma, tudo o que foi exposto aqui não é conclusivo e somente mostra a necessidade da continuidade das pesquisas, que já prosseguem. A única coisa que se observa com certeza, no entanto, é que há grande diversidade do modo de vida caçadorcoletor na área de estudo, fato esse que corrobora com o que afirma Alan Barnard sobre sua justificativa da realização de mais Congressos Internacionais e estudos sobre essas Sociedades. Segundo ele, “enquanto a diversidade nos modos de vida caçador-coletor já se tornou comum no discurso antropológico, e mesmo nos títulos das monografias de 
antropologia, permanece, entretanto, o reconhecimento de que as sociedades caçadorascoletoras têm o suficiente em comum para fazer deles uma categoria e continuar as discussões” (Barnard, 2004: 4).

\section{V.2) CAÇADORES-COLETORES COMO PARTE DA HISTÓRIA DO INTERIOR PAULISTA}

Com o maior volume de vestígios da ocupação pré-histórica na região central do Estado de São Paulo, aumenta nossa preocupação com a preservação desse patrimônio. Grande parte de sítios identificados atualmente se dá pela Arqueologia de Contrato, que está vinculada aos estudos de impactos ambientais. Isso significa então, que o número de obras impactantes vem crescendo e, dessa forma, a integridade desses remanescentes do passado corre risco. Por isso, a necessidade de mostrar ao poder público e ao cidadão a importância da conservação desse bem nacional, que agrega dados à nossa História, se faz presente desde o início de nossas atividades na região em estudo.

Em uma História contada pelo olhar etnocêntrico do europeu, onde o ameríndio não faz parte da constituição do povo brasileiro, mostrar a importância da preservação e conservação do patrimônio arqueológico não é algo simples, ainda mais quando estamos tratando de sítios compostos por “pedras”. Dessa forma, não há identificação da população com esse tipo de material. Afinal, não faz parte da vida de seus ancestrais, não há uma ligação direta e, conseqüentemente, tudo o que for relacionado aos primeiros habitantes de nosso continente não será valorizado. Para agir nesse sentido então, é necessário desenvolver trabalhos que despertem nessas pessoas o sentimento de ligação com o patrimônio arqueológico, trazendo o reconhecimento desse material e identificação com

ele, para que assim, o desejo de preservá-lo se torne natural. Como nesse caso não existe a relação com o ancestral indígena, a possibilidade é explorar, assim como destaca Ulpiano Bezerra de Meneses, duas matrizes de valores que o patrimônio pode representar: a pertença e o trabalho humano investido. Em toda nossa História, não deixamos de ser marcados pela territorialidade, o homem pertence a um espaço e ser de um certo lugar não expressa vínculo de propriedade, mas uma rede de relações. "Se, com a memória, explora- 
se a dimensão temporal do homem, com a pertença está em cena o conteúdo espacial da existência" (Meneses, 2007:51). Seguindo essa lógica, o dado arqueológico oferece a medida da ação humana e do trabalho humano, conferindo uma espécie de selo de dignidade ao espaço que se está presente. Assim, independentemente da distância e da diferença, há uma trilha de identificação, que introduz qualidade de vivência. Dessa maneira, "os antepassados não precisam ser ancestrais" (Meneses, 2007: 52), e existe, logo, a conexão com o lugar e, por conseguinte, nesse caso, com o patrimônio arqueológico.

Com esse intuito, sempre desenvolvemos, paralelamente às atividades com a Arqueologia, junto ao poder público e população das cidades trabalhadas - especialmente os municípios de Jaú e Araraquara - ações de conscientização e sensibilização quanto à importância da preservação de nosso patrimônio arqueológico.

Foram realizados simpósios de Arqueologia e História, cursos de introdução a Arqueologia, palestras, workshops, aulas junto a ONG’s, faculdades, escolas públicas e particulares, atividades práticas em museus, laboratórios e em campo, além de levar a representação da ciência Arqueológica na política local. Todas as atividades foram desenvolvidas e levadas a cabo com o auxílio e incentivo das Secretarias de Cultura das Prefeituras locais e instituições de ensino dos municípios de atuação, além também de algumas iniciativas privadas. 

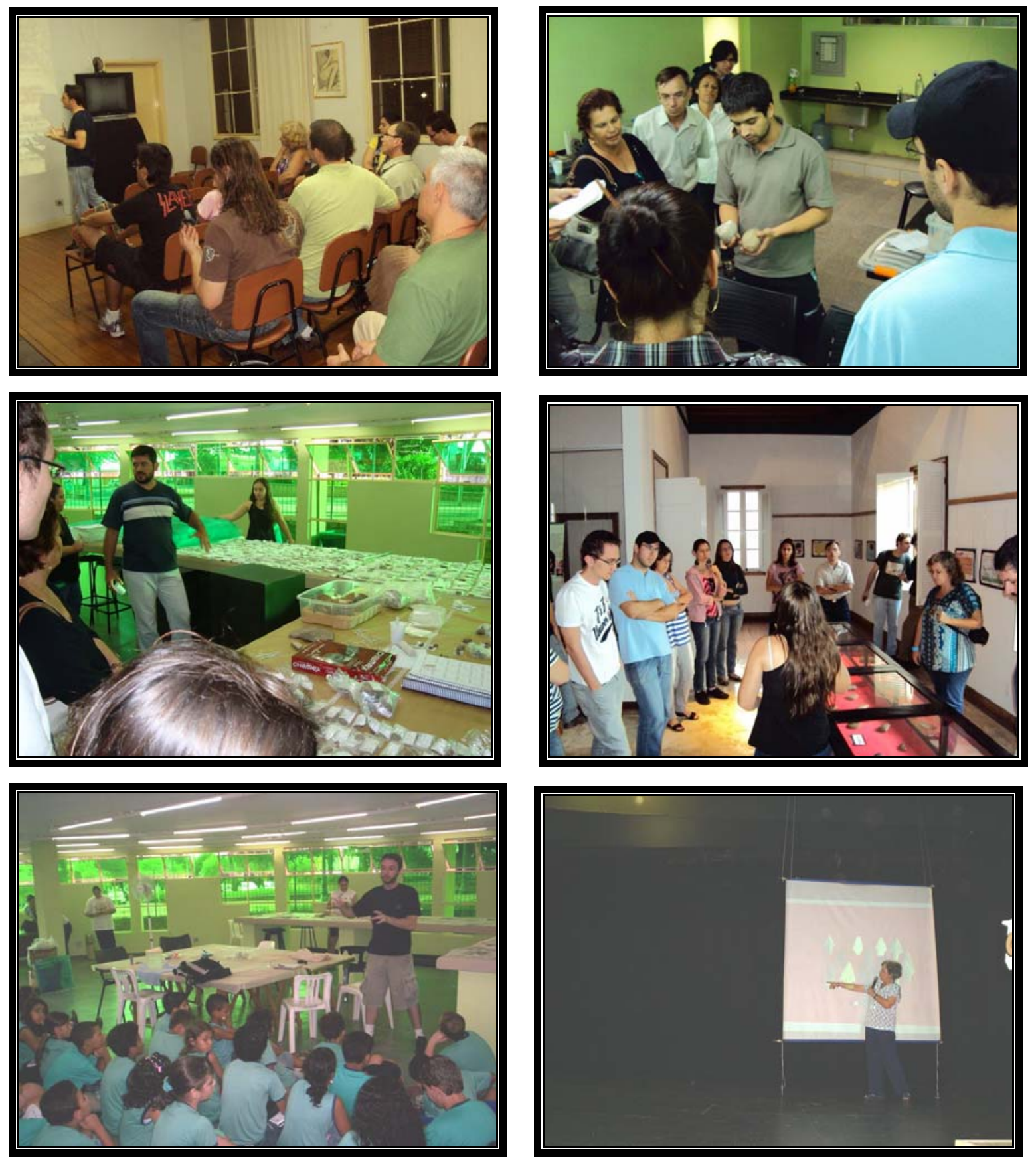

Imagens 13 a 18 respectivamente: Curso de introdução a Arqueologia no Museu Municipal de Jaú (04/2010); aula prática sobre material lítico no laboratório de Arqueologia do MAPA - Museu de Arqueologia e Paleontologia de Araraquara (06/2010); Apresentação de material arqueológico em laboratório (06/2010); Visita ao acervo do MAPA (06/2010); palestra sobre arqueologia do interior paulista para alunos do quarto ano do ensino fundamental de escola estadual do Município de Matão/SP (03/2009); $1^{\text {o }}$ Simpósio Jauense de História e Arqueologia (2005). 


\section{PERSPECTIVAS}

As informações e resultados apresentados neste trabalho não concluíram as propostas lançadas e hipóteses levantadas. Se por um lado algumas questões iniciais foram respondidas, por outro, muitas outras surgiram. Dessa forma, não seria pertinente chamar o capítulo final de "conclusão" ou "considerações finais”. Os questionamentos que se fizeram só mostraram a relevância da continuidade das pesquisas na área em destaque. Por isso, decidimos então, apresentar as perspectivas quanto ao prosseguimento dos estudos.

Como foi várias vezes ressaltado, um dos principais objetivos de nossa pesquisa foi buscar uma abordagem regional quanto a ocupação dos grupos caçadores-coletores, através de seus vestígios líticos, no centro-oeste paulista. Sabemos que para esse fim ser alcançado de fato, uma amostragem maior de sítios é necessária, bem como a respectiva análise de suas indústrias líticas e demais características, para que assim, uma comparação adequada seja feita e uma representação mais fidedigna desenvolvida. Fizemos mais então, um trabalho de início, algo que mostre nossa maneira de pensar como se deve fazer a Arqueologia no interior paulista e que instigue novos investigadores, abrindo caminho para

pesquisas futuras. É nesse sentido que se desenvolvem, no momento, as atividades do Grupo de Estudos Arqueológicos de Araraquara e de pesquisadores da região. Nossos esforços, atualmente, se dirigem para:

- Levantamento de mais sítios líticos de forma sistemática e oportunística, seguindo os "geoindicadores”, informações documentais e orais;

- Análise mais detalhada do material lítico coletado;

- realizar mais intervenções arqueológicas nos sítios identificados e também no BES II, para identificar áreas de atividades distintas, buscar materiais de outra natureza (orgânica), realizar estudos tafonômicos e obter novas datações. Além de elaborar projeto para transformá-lo em sítio escola;

- realizar junto ao grupo de estudos arqueológicos de Araraquara e interessados, experiências de lascamento e criar uma coleção de referência, com a matéria-prima local, para que sirva de base em futuros estudos interpretativos;

- Continuar com as atividades educativas junto à comunidade local; 
- Atuar na preservação do patrimônio arqueológico regional.

A partir dessas ações, teremos no futuro, uma amostragem maior de sítios, o que possibilitará uma comparação mais adequada. Novas informações surgirão, confirmando ou não as hipóteses por hora levantadas e discutidas. O que podemos afirmar, é que observamos uma região muito rica arqueologicamente e que merece a intensificação das pesquisas. Esperamos assim, que este trabalho fique como uma referência sobre as informações arqueológicas coletadas até o momento e também de convite, para que haja continuidade nos estudos.

\section{REFERÊNCIAS BIBLIOGRÁFICAS}

AB’SABER, A. N. (1957) Geomorfologia do Sítio Urbano de São Paulo.

AB'SABER, A.N. (1977) Expansão dos espaços ocupados por climas secos por ocasião das Glaciações Quarternárias.

AFONSO, M.C. (1987) A ocupação pré-histórica na região de Serra Azul e São Simão(SP): Um estudo Geoarqueológico. Dissertação de mestrado, USP-SP, SP.

ARARAQUARA. (1975) Prefeitura Municipal. Araraquara: antecedentes históricos. Prefeitura Municipal de Araraquara: Assessoria de Planejamento, jun.

ARAÚJO, Astolfo. G. M. (1995) Levantamento Arqueológico da Área Alto Taquari, Estado de São Paulo, com Ênfase na Abordagem dos Sítios Líticos. Dissertação de Mestrado apresentada a FFLCH/USP.

. (2001) Teoria e Método em Arqueologia Regional: Um

Estudo de Caso no Alto Paranapanema, Estado de São Paulo. Tese de Doutorado apresentada a FFLCH/USP. 
- (2001b) A Arqueologia da Região de Rio Claro: Uma

Síntese. In: Revista do Museu de Arqueologia e Etnologia da Universidade de São Paulo. $\mathrm{N}^{\mathrm{o}} 11$.

ARAÚJO, Astolfo. G. M. (2004) A Variabilidade Cultural no Período Paleoíndio no Brasil (11.000 - 8.000 AP): Algumas Hipóteses. In: Revista do CEPA, Santa Cruz do Sul, volume 28, nº 39, páginas 111-130. Jan/Jun.

BASTOS, Rossano Lopes \& TEIXEIRA, Adriana. (2005) Normas e Gerenciamento do Patrimônio Arqueológico. (org) Rossano Lopes, Haroldo Gallo e Marise Campos de Souza - São Paulo: 9 ${ }^{\text {a }}$ SR/IPHAN.

BARNARD, Alan. (Edt.) [2004] Hunter-Gatherers in History, Archaeology and Anthropology. Berg Print of Oxford International Publishers Ltda, New York

BINFORD, L. R. (1980) Willow Smoke and Dogs' Tails: Hunter-Gatherer Settlement Systems and Archaeologycal Site Formation. American Antiquity, vol. 45, nº1, p: 4-20, January.

BORGES, V.P. (1993) O que é História. 2ª ed. Rev. Coleção Primeiros Passos. São Paulo: Brasiliense.

BROWN, A. G. (1997) Alluvial Geoarchaeology. Floodplain archaeology and environmental change. Cambridge University Press.

BUENO, L. (2007) Variabilidade Tecnológica nos Sítios Líticos da Região do Lajeado, Médio Rio Tocantins. Revista do Museu de Arqueologia e Etnologia. Universidade de São Paulo. Suplemento ${ }^{\circ} 4$. 
BUENO, L. \& ISNARDIS, A.(org) [2007] Das Pedras aos Homens: Tecnología Lítica na Arqueologia Brasileira. Belo Horizonte, MG: Argvmentvm: FAPEMIG; Brasília, DF: CAPES.

CALDARELli, S.B. (1983) Lições de Pedra. Aspectos da ocupação pré-histórica no médio vale do Rio Tietê. Tese de doutorado apresentada a FFLCH-USP, São Paulo.

CALDARELLI, Solange B. \& SANTOS, Maria do C.M. (1999-2000) A Arqueologia de Contrato no Brasil. Revista USP,44(1):52-73.

CALDARELLI, Solange B.. (2001-2002) A Arqueologia do Interior Paulista Evidenciada por suas Rodovias. Revista de Arqueologia, São Paulo, n.14/15, p.29-56.

DE BLASIS, P. A.D. (1988) A Ocupação Pré-Colonial do Vale do Ribeira do Iguape, SP: Os Sítios Líticos do Médio Curso. Dissertação de Mestrado apresentada a FFLCH/USP. . (1998) Relatório Final do Salvamento Arqueológico no traçado do Gasoduto Bolívia-Brasil (GASBOL) no Estado de São Paulo - Trecho Paulínia/Rio Paraná. MAE/USP, SP, não publicado.

DE BLASIS, Paulo A. D. (2001) Brasil 50 mil anos - Uma viagem ao passado colonial. Guia temático para professores. MAE - Universidade de São Paulo.

DIAS, A.S. (2003) Sistemas de Assentamento e Estilo Tecnológico: Uma proposta Interpretativa para a Ocupação Pré-Colonial do Alto Vale do Rio Sinos, Rio Grande do Sul. Tese de doutorado apresentada ao departamento de Geografia da FFLCH-USP, São Paulo. 
DOCUMENTO Antropologia e Arqueologia. (2001) Projeto de Resgate Arqueológico Usina Termelétrica Duke 1, Município de Pederneiras, SP. Relatório Final, não publicado

FIGUTI, L. Origens e expansão das sociedades indígenas. Guia temático para professores. MAE - Universidade de São Paulo.

FUNARI, P.P.A. (1988) Arqueologia. São Paulo: Brasiliense.

FUNARI, P.P.A. \& CARVALHO, Aline V. (2005) Palmares ontem e hoje. Descobrindo o Brasil. Rio de Janeiro: Jorge Zahar Ed.

GALHARDO, D. (2010) Tecnologia lítica: estudo da variabilidade em sítios líticos do nordeste do estado de São Paulo. Dissertação apresentada ao Museu de Arqueologia e Etnologia da Universidade de São Paulo.

GUIDON, N. (2005) Povoamento das Américas. A Arqueologia - Parque Nacional Serra da Capivara. Fumdham.

HILL, K.; HURTADO, A.M. The Aché of Paraguay. (2001) In: LEE, Richard B.; DALY, Richard. (ed.) The Cambridge encyclopedia of hunters and gatherers. New York: Cambridge University Press.

HOBSBAWM, E. (1988) Sobre História. São Paulo: Cia das Letras.

IBGE. (1966) Jaú - Edição comemorativa do Primeiro Centenário de criação do Município. Rio de Janeiro: IBGE (Coleção de Monografias, v. 330).

IHERING, H. von. (1904) Os Guaianãs e Caingangues de São Paulo. Revista do Museu Paulista. São Paulo, v. 6. 
INGOLD, T. (2001) On the social relations of the Hunter-gatherer band. In: LEE, R.B. \& DALY, R. (ed) The Cmabridge encyclopedia of hunters and gatherers. New York: Cambridge University Press, p. 399-410.

KELLY, R.L. (1995) The Foraging Spectrum: Diversity in Hunter-Gatherer Lifeways. Washington: Smithsonian institution.

LAMING-EMPERAIRE, Annette. (1967) Guia para o Estudo das Indústrias Líticas da América do Sul. In: MANUAIS de Arqueologia, II. Curitiba: UFPR.

LANATA, J.L. \& BORRERO, L.A. (1999) The Archaeology of Hunter-gatherers in South America. Recent History and new Directions. In: POLITIS, G.G. \& ALBERTI, B. Archaeology in Latin America. London: Routledge, p. 76-89.

LARAIA, R.B. (2000) Cultura: Um conceito Antropológico. 13a ed. Rio de Janeiro: Jorge Zahar Ed.

LEE, R. \& DEVORE, I. (1968) Man the Hunter. Chicago: Aldine.

LEMOS, Alberto. História de Araraquara. Edição do Museu Histórico e Pedagógico “Voluntários da Pátria” e Prefeitura Municipal de Araraquara. São Paulo, Typografia Fonseca, s.d.

LEROI-GOURHAN, A. (1985) O gesto e a palavra I - Técnica e Linguagem. Lisboa, Edições 70. p. 1-150.

MANO, M. (1998) Os Campos de Aracoara: um ensaio de perspectiva Etnohistórica. Revista Uniara, Araraquara, 3: 13-37.

MARANCA, S. (1974) Relatório das atividades do 4 e 5 anos do PRONAPA no Estado de São Paulo.PRONAPA 5. Publicações Avulsas 26:117-126, MPEG, PA. 
MARAnCA, S., SILVA, A. L. M. e SCABELlO, A. M. P. (1994) Projeto Oeste Paulista de Arqueologia do Baixo e Médio Vale do rio Tietê: síntese dos trabalhos realizados. Revista do Museu de Arqueologia e Etnologia 4: 223-226, SP.

MENESES, Ulpiano B. (2007) Premissas para a Formulação de Políticas Públicas em Arqueologia. Revista do Patrimônio Histórico e Artístico Nacional, № 33: 37-57.

MICHELUTTI, Pedro. (2010) Geoecologia do Segmento Oriental dos Campos de Araraquara - Tentativa de Compartimentação. Não publicado.

MILLER, T.O. Jr. (1968) Duas fases paleoindígenas da bacia do Rio Claro, São Paulo: um estudo em metodologia. Tese de Doutoramento, FFLCH-Rio Claro.

. (1969) Pré-história da região de Rio Claro, São Paulo; Tradições em divergência. Cadernos Rio Clarenses de Ciências Humanas 1:22-52, Rio Claro.

. (1972) Arqueologia da Região Central do Estado de S.P. In: Dédalo, vol. 16, ano VIII, SP.

MORAIS, J.L. Estudo do Sítio Camargo 2 - Piraju/SP: ensaio tecnotipológico de sua indústria lítica. Revista do Museu Paulista, Nova Série, vol. XXXIII, SP, p. 41-128.

. (1990) Arqueologia de Salvamento no Estado de São Paulo. Dédalo, São Paulo, MAE/USP, v. 28, SP

. (1999) Perspectivas Geoambientais da Arqueologia do Paranapanema

Paulista. Tese de livre-docência apresentada ao MAE-USP, São Paulo.

. (1999-2000) Arqueologia da Região Sudeste. Revista USP, 44(2):194-

217. 
NUNES, Luiz Coimbra. (2008) Terminologia Lítica: Tecnologia para o Estudo da Pedra Lascada. Dissertação apresentada ao Programa de Mestrado Profissional em Gestão do Patrimônio Cultural, da Universidade Católica de Goiás.

OLIVEIRA, W.C. (2007). Caçadores Coletores na Amazônia: Eles existem. Dissertação apresentada ao programa de pós-graduação em Arqueologia, do Museu de Arqueologia e Etnologia da Universidade de São Paulo.

PALANCA, R. T. S. \& KOFFLER, N. F. (1996) Avaliação agrícola das terras da Bacia do rio Jaú (SP) através das técnicas de geoprocessamento. Fundação Educacional “Dr. Raul Bauab”. Faculdade de Filosofia, Ciências e Letras (FAFIJA) Jaú.

PALleSTRINI, L. (1981/2) Cerâmica há 1.500 anos, Mogi-Guaçu, Estado de São Paulo. Revista do Museu Paulista 28:115-129, USP, SP.

. (1985) O cenário de Sete mil anos, in: Ciência Hoje, vol. 4 nº19, SBPC, SP, Jul/Ago.

POLEZZE, Geraldo. (1972) Em Araraquara, descobertas mais duas urnas mortuárias indígenas. Folha de São Paulo, abril.

PROUS, A. (1992) Arqueologia Brasileira, Ed. UnB, Brasília, DF.

RAPP, Jr., G. \& HILL, C.L. (1998) Geoarchaeology. The earth-Science Approach to Archaeological Interpretation. Yale University Press.

ROBRAHN-GONZÁleS, E. \& ZANETINI, P. (2001) Programa de levantamento e resgate arqueológico - Fábrica da EMBRAER, Documento, SP, não publicado. 
RODRIGUES, R. \& SCHIAVETTO, S.N.O. (2007) Programa de Avaliação Arqueológica - Área de Implantação do Cultivo de Cana-de-Açúcar, Usina Zanin, Região de Araraquara, Estado de São Paulo. Relatório Final, não publicado.

SCABELLO, A. L. M. (1997) Estudo das Populações de caçadores-coletores do Médio Curso do Rio Tietê: o estudo de caso do Sítio Três Rios, Município de Dois Córregos, SP. Tese de Mestrado apresentada a FFLCH-USP, São Paulo.

SCATAMACCHIA, Maria C.M. (1989) Arqueologia e etno-história: cronistas do século XVI. Dédalo, publicações avulsas, 1:135-139. São Paulo.

SCHADEN, Egon. (1954) Os primitivos habitantes do território paulista. Revista de História, São Paulo, 18.

SCHIAVETTO, S.N.O. (2005) Levantamento Arqueológico no Médio Mogi-Guaçu e Médio Jacaré-Guaçu/SP: um primeiro olhar sobre os sítios cerâmicos. Anais do XIII Congresso da SAB: arqueologia, patrimônio e turismo. Campo Grande,MS. Ed. Oeste.

. (2007) Arqueologia Regional e Educação: Proposta de Estudos Sobre um “Passado Excluído” de Araraquara/SP. Tese de Doutorado apresentada ao IFCH da Unicamp/SP.

SCIENTIA CONSULTORIA CIENTÍFICA. (2004) Projeto de Prospecção Arqueológica na Área de Intervenção da LT 525kw Londrina (PR) / Araraquara (SP). Relatório Final. SP. Scientia, não publicado.

(2004a) Projeto de Levantamento Arqueológico Intensivo na Faixa de Domínio na Rodovia Engenheiro Paulo Nilo Romano (SP-225). Trecho Itirapina-Jaú, São Paulo, a e b. Scientia, não publicado. 
(2005a) Projeto de Levantamento Arqueológico Intensivo na Faixa de Domínio na Rodovia Engenheiro Paulo Nilo Romano (SP-225). Trecho Itirapina-Jaú, São Paulo. Scientia, não publicado.

. (2005) Resgate do Sítio Arqueológico Dois

Córregos, Município de Dois Córregos, SP. Relatório Final, não publicado.

. (2006) Projeto salvamento arqueológico na área de modernização da pequena central hidrelétrica Gavião Peixoto, município de Gavião Peixoto, SP. São Paulo. Scientia, não publicado.

. (2008) Salvamento de Sítios Arqueológicos

Situados na Área de Intervenção da Linha de Transmissão 525 Kv Londrina (PR) Araraquara (SP). Relatório Final, não publicado.

(2008) Projeto de Prospecção

Arqueológica para LT 138 Kv Bariri - Barra Bonita, Boracéia, Bariri, Itapuí, Jaú, Barra Bonita e Igaraçu do Tietê (SP). Arcadis Tetraplan/CTEEP, não publicado.

SILVA, F.A. Arqueologia Pré-Histórica de Rio Claro-SP, In: Revista do Museu Paulista, SP.

SILVA, F.A. 2000. As Tecnologias e seus Significados. Tese de Doutoramento apresentada ao programa de pós-graduação em Antropologia da Faculdade de Letras e Ciências Humanas da USP.

SOUZA, A. M. \& CREMONESI, F. L. (2003) Jaú - Imagens de um Rio! Copiadora “Luiz de Queiroz”. Piracicaba.

TEIXEIRA, S. (1900) Jahu em 1900. Correio do Jahu, Jahu. 
TYLOR, E. Primitive Culture. Londres, John Murray \& Co., 1871 [Nova Iorque, Harper Torchbooks, 1958].

VILHENA VIALOU, A. (1980) A Tecnotipologia das Indústrias Líticas do Sítio Almeida no seu Quadro Natural, Arqueoetnológico e Regional. São Paulo. 170 p.

(1981/1982). Étude Techn-Typologiqye des Industries

Lithiques du Site Almeida, État de Sao Paulo, Brésil. L’Anthropologie - Paris. Tome 85/86, n 3 , p 373-423.

- (1983-4) BRITO - O mais antigo sítio arqueológico do

Paranapanema-SP, In: Revista do Museu Paulista, N.S., vol. XXIX.

. (2005) (dir). Pré-História do Mato Grosso. Vol. 1, Santa

Elina, Edusp, Sao Paulo.

WEHLING, A. \& WEHLING, M.J.C.M. (1999) Formação do Brasil Colonial. $2^{\text {a }}$ Ed. Rio de Janeiro: Nova Fronteira.

ZANETTINI ARQUEOLOGIA. (2003) Programa Arqueológico Gasoduto Araraquara / Norte - Trecho Boa Esperança do Sul - Araraquara, Estado de São Paulo. Relatório Final. SP, não publicado.

- (2006) Diagnóstico Arqueológico: Sistema de

Distribuição de Gás Natural (Trecho Araraquara-Guatapará), Estado de São Paulo. Relatório Final, não publicado.

ZANETTINI ARQUEOLOGIA. (2009) Projeto “Arqueologia no Campus”: Etapa 1 Programa de Prospecções Arqueológicas na Área Histórica - UNESP, Campus de Botucatu, Botucatu/SP. Relatório Final, não publicado. 
(2010) Programa de Prospecção e Resgate Arqueológico Gasoduto Pederneiras (Rede Secundária), Estado de São Paulo. Relatório final, SP. Não publicado.

ZANETTINI ARQUEOLOGIA \& SR/IPHAN. (2010) Termo de Cooperação Técnica para o Levantamento de Sítios Arqueológicos no Estado de São Paulo.

\section{SITES CONSULTADOS}

http://www.arqueologiasp.org/arqueologia/v1/iphan/historico/ (último acesso em 06/11/2010 às 17:00)

http://www.maav.com.br (último acesso em 06/06/2010 às 21:00) 


\section{ANEXOS}




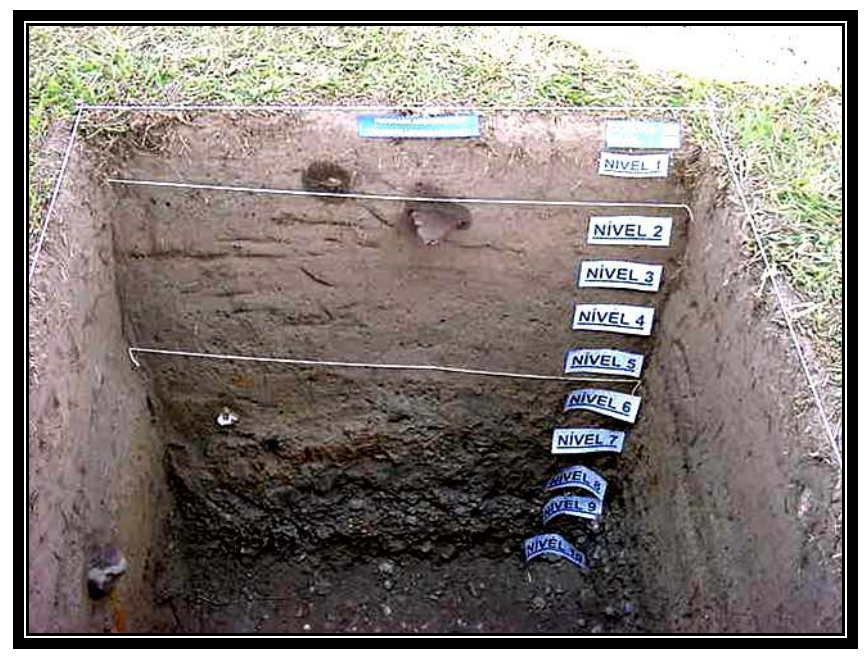

Imagem 19: Perfil estratigráfico destacando 10 níveis artificiais, 3 níveis naturais e material arqueológico aflorando - unidade de escavação Sítio BES II - etapa de campo 01 (Zanettini, 2003).

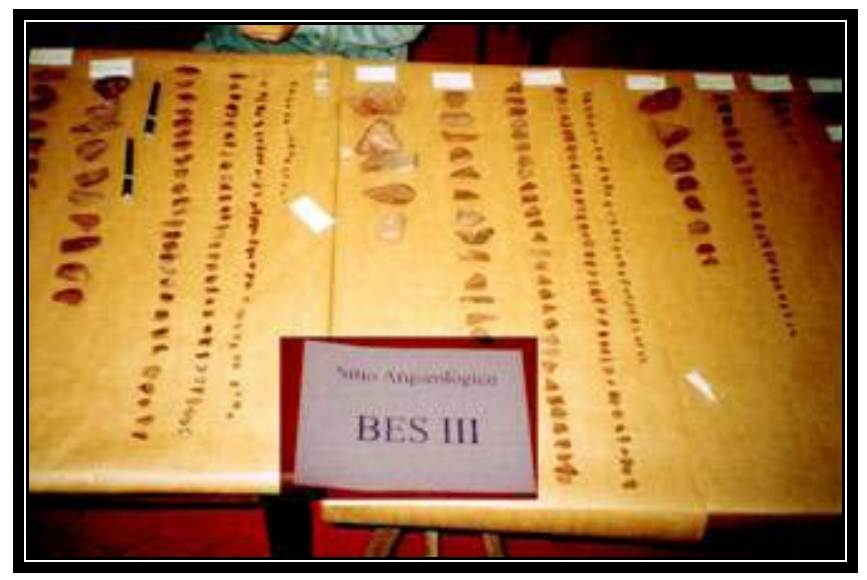

Imagem 20: Destaque do material arqueológico do Sítio BES III em Laboratório (Zanettini, 2003).

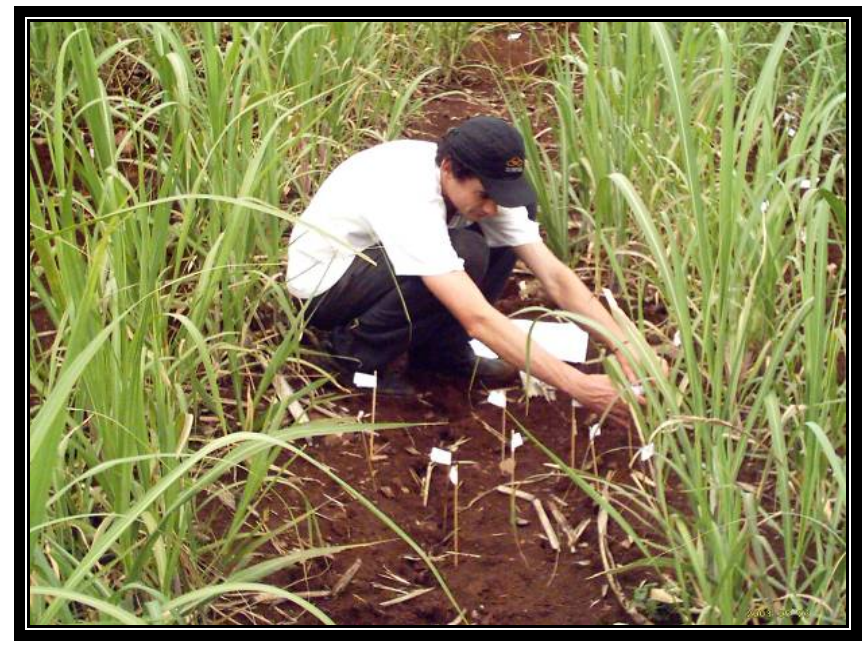

Imagem 21: Sinalização do material arqueológico aflorado para plotagem com Estação Total e coleta (Scientia, 2005). 


\title{
Datação, Comércio e Prestação de Serviços LTDA. Laboratório Datação: LOE e TL
}

\author{
Relatório de Ensaio
}

CLIENTE: FÁBIO GROSSI DOS SANTOS

Email: fabiogrossi@usp.br

\section{MATERIAL: Sedimentos}

NATUREZA DO TRABALHO: Datação de Sedimentos pelo Método da Luminescência Óticamente Estimulada.

REFERÊNCIA: Recebimento de material em 24/02/2010.

\section{AMOSTRAS}

Foram fornecidas pelo cliente 2 (duas) amostras com as designaçãos indicadas na Tabela 1, as amostras estavam acondicionadas e devidamente embaladas de forma que não tomaram luz no envio. As amostras foram recebidas em 24/02/2010 e identificadas no laboratório sob os códigos de 2527 e 2528.

\section{MÉTODO UTILIZADO}

Análise da dose acumulada - Equipamento utilizado: TL/OSL Automated Systems, Model 1100-series Daybreak Nuclear Instruments Inc.

Análise da dose anual - Equipamento utilizado: Canberra Inspector Portable Spectroscopy Workstation $(\mathrm{NaI}-\mathrm{Tl})$

A metodologia completa pode ser encontrada em nosso site:

http://www.datacao.com.br em Download 


\section{Datação, Comércio e Prestação de Serviços LTDA. Laboratório Datação: LOE e TL}

\section{RESULTADOS}

Os resultados das doses acumuladas, doses anuais e das idades estão apresentados na Tabela 1, a seguir:

Tabela 1: Código LVD, amostra, dose anual, dose acumulada e idade.

\begin{tabular}{|c|c|c|c|c|}
$\begin{array}{c}\text { Código } \\
\text { LVD }\end{array}$ & Amostra & $\begin{array}{c}\text { Dose Anual } \\
(\mu \mathrm{Gy} / \mathrm{ano})\end{array}$ & $\begin{array}{c}\text { Dose } \\
\text { Acumulada } \\
(\mathrm{Gy})\end{array}$ & $\begin{array}{c}\text { Idade } \\
\text { (anos) }\end{array}$ \\
\hline 2527 & Amostra 1: Sítio BES II & $\mathbf{5 1 0} \pm \mathbf{7 5}$ & $\mathbf{7 , 4 0}$ & $\mathbf{1 4 . 5 0 0} \pm \mathbf{3 . 0 0 0}$ \\
\hline 2528 & Amostra 2: Sítio BES III & $\mathbf{5 8 0} \pm \mathbf{5 0}$ & $\mathbf{2 , 7 0}$ & $4.500 \pm 600$
\end{tabular}

Os resultados das concentrações de ${ }^{232} \mathrm{Th},{ }^{238} \mathrm{U},{ }^{235} \mathrm{U},{ }^{40} \mathrm{~K}$ estão apresentados na Tabela 2, a seguir:

Tabela 2: Amostra, Th (Tório), U (Urânio), K (Potássio) e dose anual.

\begin{tabular}{|c|c|c|c|c|} 
Amostra & $\begin{array}{c}\text { Th } \\
(\mathbf{p p m})\end{array}$ & $\begin{array}{c}\mathrm{U} \\
(\mathbf{p p m})\end{array}$ & $\begin{array}{c}\mathrm{K} \\
(\%)\end{array}$ & $\begin{array}{c}\text { Dose Anual } \\
(\mu \mathrm{Gy} / \mathrm{ano})\end{array}$ \\
\hline 2527 & $\mathbf{1 , 9 2 4} \pm \mathbf{0 , 0 6 9}$ & $\mathbf{0 , 4 3 9} \pm \mathbf{0 , 2 7 3}$ & $\mathbf{0} \pm \mathbf{0}$ & $\mathbf{5 1 0} \pm \mathbf{7 5}$ \\
\hline 2528 & $\mathbf{2 , 4 0 6} \pm \mathbf{0 , 0 8 7}$ & $\mathbf{0 , 6 0 3} \pm \mathbf{0 , 1 6 6}$ & $\mathbf{0} \pm \mathbf{0}$ & $\mathbf{5 8 0} \pm \mathbf{5 0}$
\end{tabular}

São Paulo, 08 de Abril de 2010.

Prof. Dr. Márcio Yee

Responsável pela Análise
Profa. Dra. Sonia H. Tatumi

Coordenadora do Laboratório 
